660

R43

DUSTRIAL CHEMISTRY

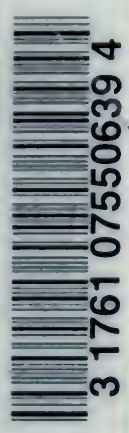
Edited by S.RIDEAL

PLANT PRODUCTS

\& Chemical Fertilisers

S.HOARE COLLINS 


$$
\begin{aligned}
& 660 \\
& \text { R43 }
\end{aligned}
$$






\title{
INDUSTRIAL CHEMISTRY
}

\author{
BEING A SERIES OF VOLUMES GIVING A \\ COMPREHENSIVE SURVEY OF
}

\section{THE CHEMICAL INDUSTRIES}

\author{
EdTed by SAMUEL RIDEAL, D.Sc. Lond., F.I.C.
} FELLOW OF UNIVERSITY COLLEGE, LONDON

ASSISTED BY

JAMES A. AUDLEY, B.SC.

W. BACON, B.Sc., F.I.C.

M. BARROWCLIFF, F.I.C.

H. GARNER BENNETT, M.Sc.

F. H. CARR, F.I.C.

S. HOARE COLLINS, M.Sc., F.I.C.

H. H. GRAY, B.Sc.

H. C. GREENWOOD, D.Sc.
J. R. PARTINGTON, D.Sc. (Vict.) ARTHUR E. PRATT, B.Sc. ERIC K. RIDEAL, PH.D., M.A., F.I.C. W. H. SIMMONS, B.Sc. R. W. SINDALL, F.C.S. SAMUEL SMILES, D.SC. D. A. SUTHERLAND, F.C.S. HUGH S. TAYLOR, D.Sc.

C. M. WHITTAKER, B.Sc. 
First Edition

Reprinted . . January, 1919 


\section{PLANT PRODUCTS AND CHEMICAL FERTILIZERS}

\section{$\infty$}

BY

S. HOARE COLLINS, M.Sc., F.I.C.

LECTURER AND ADVISER IN AGRICULTURAL CHEMISTRY, ARMSTRONG COLLEGE, NEWCASTLE-ON-TYNE (UNIVERSITY OF DURHAM) ;

FORMERLY ASSISTANT AGRICULTURAL CHEMIST TO THE GOVERNMENT OF INDIA; AUTHOR OF "HANDBOOK OF AGRICULTURAL CHEMISTRY FOR INDIAN STUDENTS"

TIVE LN35ive.

1. S C S (REPRINTED)

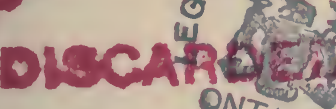

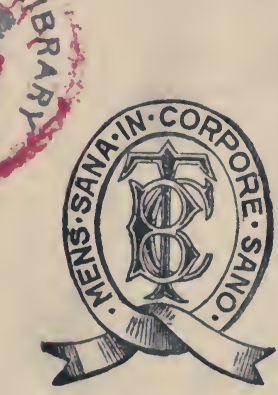

LONDON

BAILLIÈRE TINDALL AND COX

8, HENRIETTA STREET, COVENT GARDEN

1919

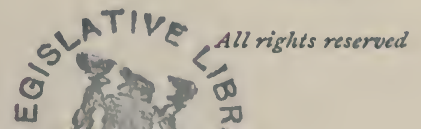


PRINTED IN GREAT BRITAIN

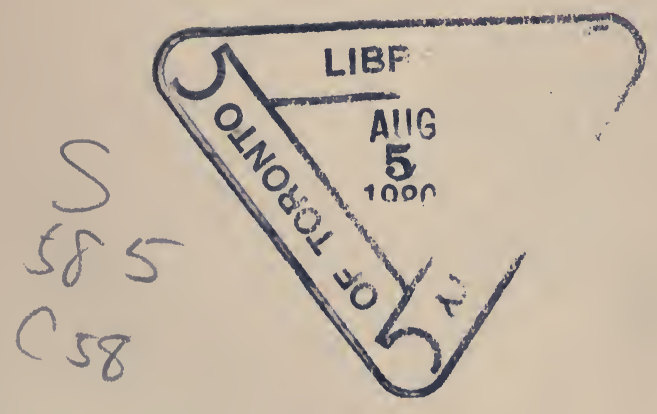




\section{1. \\ GENERAL PREFACE}

THE rapid development of Applied Chemistry in recent years has brought about a revolution in all branches of technology. This growth has been accelerated during the war, and the British Empire has now an opportunity of increasing its industrial output by the application of this knowledge to the raw materials available in the different parts of the world. The subject in this series of handbooks will be treated from the chemical rather than the engineering standpoint. The industrial aspect will also be more prominent than that of the laboratory. Each volume will be complete in itself, and will give a general survey of the industry, showing how chemical principles have been applied and have affected manufacture. The influence of new inventions on the development of the industry will be shown, as also the effect of industrial requirements in stimulating invention. Historical notes will be a feature in dealing with the different branches of the subject, but they will be kept within moderate limits. Present tendencies and possible future developments will have attention, and some space will be devoted to a comparison of industrial methods and progress in the chief producing countries. There will be a general bibliography, and also a select bibliography to follow each section. Statistical information will only be introduced in so far as it serves to illustrate the line of argument.

Each book will be divided into sections instead of chapters, and the sections will deal with separate branches of the subject in the manner of a special article or monograph. An attempt will, in fact, be made to get away from 
the orthodox textbook manner, not only to make the treatment original, but also to appeal to the very large class of readers already possessing good textbooks, of which there are quite sufficient. The books should also be found useful by men of affairs having no special technical knowledge, but who may require from time to time to refer to technical matters in a book of moderate compass, with references to the large standard works for fuller details on special points if required.

To the advanced student the books should be especially valuable. His mind is often crammed with the hard facts and details of his subject which crowd out the power of realizing the industry as a whole. These books are intended to remedy such a state of affairs. While recapitulating the essential basic facts, they will aim at presenting the reality of the living industry. It has long been a drawback of our technical education that the college graduate, on commencing his industrial career, is positively handicapped by his academic knowledge because of his lack of information on current industrial conditions. A book giving a comprehensive survey of the industry can be of very material assistance to the student as an adjunct to his ordinary textbooks, and this is one of the chief objects of the present series. Those actually engaged in the industry who have specialized in rather narrow limits will probably find these books more readable than the larger textbooks when they wish to refresh their memories in regard to branches of the subject with which they are not immediately concerned.

The volume will also serve as a guide to the standard literature of the subject, and prove of value to the consultant, so that, having obtained a comprehensive view of the whole industry, he can go at once to the proper authorities for more elaborate information on special points, and thus save a couple of days spent in hunting througli the libraries of scientific societies.

As far as this country is concerned, it is believed that the general scheme of this series of handbooks is unique, and it is confidently hoped that it will supply mental 


\section{GENERAL PREFACE}

munitions for the coming industrial war. I have been fortunate in securing writers for the different volumes who are specially connected with the several departments of Industrial Chemistry, and trust that the whole series will contribute to the further development of applied chemistry throughout the Empire. 



\section{PREFACE}

THE raw materials of Agriculture are often the waste products of the other industries, and the produce of Agriculture again forms the raw material for other industries. The following pages attempt to pick up the story of those industrial waste products which are useful as fertilizers, and carry it on through the soil and crops, until new products are available for industrial uses. Among the many plant products which are obtained from the soil, food takes a high position as an industrial raw product, since neither men nor horses could work without it. No particular effort is made to give encyclopædic completeness of information, but the aim has been to give a fair conspectus of a large subject, with an appended bibliography for those who are able to pursue their studies further. Details of analytical chemistry are not considered in this volume unless the standard text-books named in the Bibliography appear incomplete or unsuitable. The volume covers the cycle from factory to fertilizer, from fertilizer to field, and from field to factory once more.

I have to thank Mr. A. S. Blatchford, M.Sc., for valuable help in revising proof-sheets.

S. HOARE COI,INS.

February, 1918. 


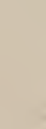




\section{CONTENTS}

\section{CONTENTS}

\section{INTRODUCTION}

Brief view of authorities.

The Sun as a source of energy. The vegetable leaf as an absorptive agent to convert Solar energy into Chemical energy. The soil as a medium for vegetable growth. The chief factors determining

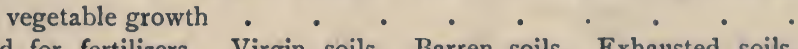

Need for fertilizers. Virgin soils. Barren soils. Exhausted soils.

Losses and gains in Nature. Losses and gains in practice . . 3

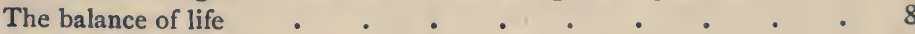

References.

PART I.-FERTILIZERS.

\section{SECTION I.-NITROGEN GROUP OF FERTILIZERS.}

General properties

(a) Sulphate of Ammonia. Origin. Useful and impracticable mixtures. Application to the land. Physical and chemical properties. Time to apply. Secondary effects on the soil. Effects on crops. Crops most suited for sulphate of ammonia

(b) Ammoxium Chloride, Nitrate, and Carbonate . .

(c) Nitrate of Soda. Origin. Mixtures. Application to the land. Physical and chemical properties. Time to apply. Methods of application. Ultimate effect on the soil. Effect on the crop grown. Crops most suited to nitrate of soda.

(d) Nitrate of Lime. History. Crops best suited. Difficulties of application. Suitable mixtures

(e) Nitrate of Potash. History. Indian and Egyptian methods of manufacture. Local agricultural uses. Nitre earths. Nitre wells. Manufacturing wastes

(f) Calcium Cyanamide. Nitrolim. Storage. Properties. Difficulties of application to soil. Times to apply. Crops most suited. Secondary effects on the soil 
(g) Organic Nitrogen Manures. Fish meal. Composition. Types of soil and crop most suited. Objections and difficulties. Dried blood. Hoofs and horns. Refuse oil cakes. Industrial waste materials . . 22

References .

\section{SECTION 2.-THE PHOSPHORUS GROUP OF FERTILIZERS.}

General properties. Chemical condition. The different phosphorus compounds used as fertilizer

(a) Basic Slag. History and development. Composition. Citric solubility. Fineness. Application to the soil. Soils most suited. Crops giving good returns. Factors needed to ensure success. Secondary and ultimate effects on the physical condition of the soil. Lasting effect .

(b) Mineral Phosphates. Occurrence and distribution. Direct use on the land. Secondary effects. Water solubility. Citric solubility. Solubility in other reagents. Reversion

(c) Fertilizers containing both Nitrogen and Phosphorus. Bones. Bone meal. Bone flour. Dissolved bones. Guano. Mixtures to imitate guano or dissolved bones. General considerations on time to apply mixed nitrogen and phosphorus fertilizers. Their relative value and suitability on different soils and to different crops . . . . . . 32 References

\section{SECTION 3.-POTASSIUM GROUP OF MANURES}

German potash manures. Geological origin. Kainit. Muriate and sulphate. Nitre. Wood ashes. Blast furnace dust. General reactions of potash manures in the soil

References .

\section{SECTION 4.-MIXED FERTILIZERS.}

(a) Containing nitrogen, phosphorus, and potassium. (Artificial mixtures).

(b) Farm-yard manure. Its constituents ; cow, pig, sheep, and horse dung. Urine of farm animals. Litter used in making manure. Physical properties of litter

(c) Nitrogen, phosphorus, and potassium. Passage from food to dung-heap. Relationship between type of food and type of beast and sort of manure produced. Quantities made under varying conditions

(d) Storage of manure. Denitrification. Drainage. Preservation. Effect of farm-yard manure on the soil. Valuation of farm-yard manure.

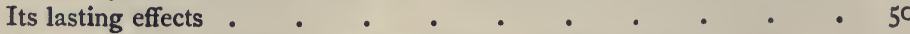

(e) Human excreta. Sewage. Sewage farms. Sewage sludge . $\quad 54$

(f) Poultry dung. Composts. Vegetable mould. Beech mast. Peat. Humogen. Seaweed . . . . . . . 56

References 
PART II.-SOILS.

\section{SECTION I.-SOILS AND THEIR PROPERTIES.}

(a) Different kinds of soils and their physical properties . . . . 60

(b) Relation of soil to water. Methods of modifying the water capacity of soils . . . . . . . . . . . 67

(c) The chemical properties of the different classes of soils . . . 70

(d) Useful and useless elements. Balance of fertilizers. Available and total plant food in soils . . . . . . . . 72

(e) Relation of soil to air. Biological condition of soils. Fixation of nitrogen . . . . . . . . . 80

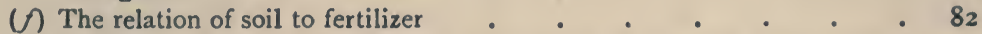

(g) "The law of diminishing returns" from both its scientific and practical aspects

References .

\section{SECTION 2.-SPECIAL SOIL IMPROVERS.}

(a) Lime. Various forms of lime. Industrial waste lime. Gypsum and its special uses. Reasons why plastering has gone out of fashion . $\quad 86$

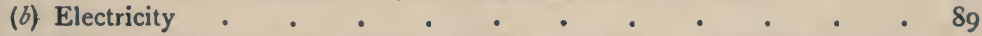

(c) The partial sterilization of soils. Application of heat. Germicides. Gas lime. Naphthalene. Soil injuries. Effect of bad drainage. Injuries due to unskilful cultivation . . . . . . . 90

References .

\section{SECTION 3.-SOIL RECLAMATION.}

(a) Barren lands. Causes of barrenness

(b) Dry lands, Their treatment and improvement ${ }^{\circ} \cdot \bullet^{\circ} \quad{ }^{\circ}$

(c) Wet lands. • • 94

(d) Peat. Its reclamation and improvement . • • . . . 97

References . . . . . . . . . . . . . 100

\section{PART III.-CROPS.}

\section{SECTION I.-PHOTOSYNTHESIS.}

The conversion of Solar energy into materials which in their turn develop Animal energy. The materials in the crops produced by solar energy. Their relationship to the fertilizers used. The economy in solar energy obtained by the proper use of fertilizers . . . . . IOI References. 


\section{SECTION 2.-THE CARBOHYDRATES PRODUCED} IN CROPS.

(a) Sugar. Its production in tropical and temperate climates. The manufacture and purification of sugar. Sugar-cane, sugar beet, dates, mangels, turnips

(b) Starch. Its production and manufactured forms. Wheat, maize, rice, potatoes, sago, tapioca .

PAGE

(c) Cellulose. Fibres, etc. The chief kinds. Their manufacture and uses. Cotton, linen, jute, hemp, timber, paper . . . . . . I24

(d) Gums and mucilage . . . . . . . . . . $13 \mathbf{I}$

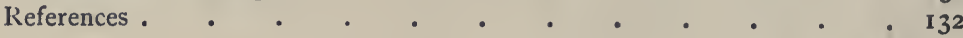

\section{SECTION 3.-THE OIL-BEARING PLANTS.}

(a) Linseed. Its growth and use for oil and cattle food. Poisonous compounds sometimes developed .

(b) Cotton. Its growth and use for oil and cattle food. Different kinds of products according to climate and methods of manufacture

(c) Soya bean. Growth and methods of pressing for oil and cattle food

(d) Palm-nuts and coconuts. Their growth and use for oil, butter substi-

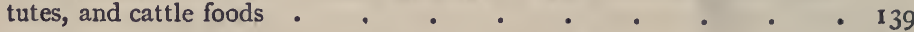

(e) Earth-nuts. Rape, safflower, sesame, niger, mowha . . . . I42

(f) The essential oils . . . . . . . . . . 145

References • • • • . . . . . . . • I45

\section{SECTION 4.-THE NITROGEN COMPOUNDS IN PLANTS.}

\begin{tabular}{|c|c|c|c|c|c|c|c|c|c|c|c|c|}
\hline (a) & Cereal proteins & - & - & • & - & - & - & - & - & - & - & 147 \\
\hline (b) $\mathrm{I}$ & Legumen proteins & . & - & • & - & • & - & . & - & : & - & 150 \\
\hline (c) 1 & Root crop proteins & & • & • & - & - & - & - & - & • & • & 151 \\
\hline (d) & Oil seed proteins & . & • & . & - & - & - & - & - & - & • & I5I \\
\hline (e) 1 & The alkaloids & - & - & - & - & . & - & • & - & - & • & 152 \\
\hline Refe & ferences . & - & - & - & - & • & - & • & - & - & - & 157 \\
\hline
\end{tabular}

\section{SECTION 5.-MISCELLANEOUS PLANT PRODUCTS.}

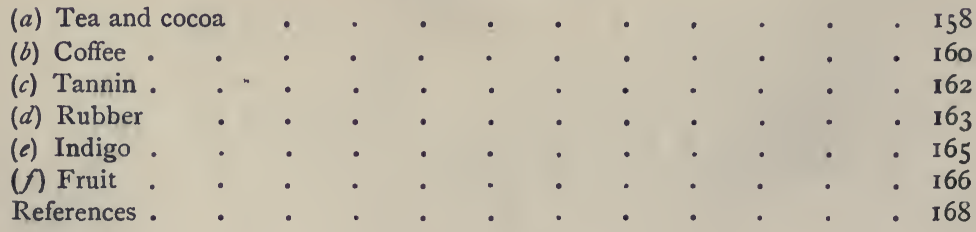




\section{SECTION 6.-PRODUCE VARIABILITY.}

The specific effects of the different fertilizers on the different crops and parts of the same crop. Accelerated and delayed ripening. Assisted root development .

Substances and conditions which prevent crops from obtaining the nutriment

References . provided by the fertilizers given . . . . . . 176

\section{PART IV.-THE PRODUCTION OF MEAT. \\ SECTION r.-MANURING FOR MEAT.}

The effect of fertilizers on the pastures and then on the beasts grazing. In-

fluence of the fertilizers used on the amount of meat produced. The animal as a machine for converting the low-grade food into high-grade food. The metabolic changes taking place in the animal body.

Tryptophane and the purine bases . . . . . . . 178 References.

\section{SECTION 2.-THE FOODS FED TO BEASTS.}

(a) Water in foods. The water supply. Amounts necessary. Effects of excess . . . . . . . . . . $18_{3}$

(b) The fat in foods. Origin of fat. Composition of fat . . . . 184

(c) The proteins. The amides . . . . . . . 185

(d) The carbo-hydrates : sugar, starch, pectin, mucilage, etc. . . . I86

(e) The fibrous materials : cellulose, lignin, etc. ․ . . . . 187

(f) Digestion. Methods by which digestion has been measured in fattening beasts . . . . . . . . . . 188 References .

\section{SECTION 3.-CALORIFIC VALUE OF FOODS.}

The animal as a heat engine. Loss of energy due to urea. Bacteria, chewing, alimentation, etc. Different systems of valuing foods. Their respective merits under different conditions. The relative values of different classes of stock as a means of converting cattle food into human food

References .

\section{SECTION 4.-DAIRY PRODUCTS.}

As high-grade products obtained from low-grade products _ . . 199 References . 


\section{SECTION 5.-FUTURE DEVELOPMENTS.}

(a) Increase of field fertility by sound management .

(b) Development of agriculture at home and abroad

(c) Financial aspect of agriculture

(d) Labour difficulties .

(c) Education

(f) Economic production of meat in Winter

References .

GENERAL BIBLIOGRAPHY 


\section{PLANT PRODUCTS}

\section{INTRODUCTION}

THE study of the products of plant life that are useful to man formed one of the first deliberate actions of early intelligence. Ancient records of China, India, and Egypt alike show that the study of the products of plants attracted early attention.

The Latin authors, Virgil, Columella, and others who wrote on Agricultural subjects, are well known in the schools, and about two hundred years ago, Jethro Tull, the inventor of the first seed drill, wrote on nitre, water, and fire and earth, as the origins of plant products. Humphrey Davy, one hundred years ago, published his Lectures on Agricultural Chemistry, and up to thirty years ago many of the Professors of Chemistry in the Universities, as a means of bringing home the truths of their science to the members of their audience, drew more illustrations from rural life than from the urban industries.

Turning now to those who specialized in Agricultural Science in England in recent years, we find such well-known names as Lawes and Gilbert, who gave Rothamsted a worldwide reputation, and Augustus Voelcker, whose work in the Royal Agricultural Society laid the foundations of many of the modern inquiries into Agricultural Science. Numerous investigators have followed in the footsteps of these pioneers, and the following pages will be found full of references to their valuable work in building up an exact science of chemistry applied to economic problems of the agriculture of to-day.

The sun is the source of power. The effective utilization D. 
of solar energy in the production of plant material lies at the basis of all Agricultural Science and Practice. The vegetable leaf in the plant is the prime mover which starts a long chain of chemical change, which begins with the energy derived from the sun and the crude materials brought chiefly by the winds, and is supplemented by operations and materials more under human control.

For nearly all plant products we require-

(I) The radiation from the sun.

(2) A supply of water.

(3) A supply of air.

(4) A supply of fertilizers.

(5) Correct conditions of heat, chemical reaction, and bacterial development.

In areas which are both tropical and continental the sun's heat may be excessive for plant development, whilst in polar regions the supply of solar heat is deficient; but the major part of the earth's surface receives enough heat for ample plant life.

In certain districts the amount of water may be excessive and in other districts the reverse may be the case, but recent study shows that these difficulties can be minimized if not overcome. The supply of air to the leaf is usually sufficient, but the supply of air to the roots of a plant very frequently needs careful management to obtain the best result.

Some soils are fairly well supplied by nature with appropriate fertilizers, but since the requirements of man are very diverse, it is a virtual impossibility for a soil to be so "fertile" that it needs no manure to produce the intensive and varied crops which modern conditions may demand.

Economic conditions may, however, prevent the production of a maximum crop under intensive cultivation. It does not always pay to produce maximum crops, and hence some lands are said to be so fertile as not to need fertilizers. The present war is teaching us that too much reliance may be put upon the economic aspect of food production; that the interests of the nation are not identical with those of the producer. 
No soil is perfect; no soil quite hopeless ; much can be done to improve the bad, and much can be left undone to injure the good. Those soils which have grown grass or timber for many years have a great accumulated fertility and need but little, if any, fertilizer, though it is not infrequently the case that such "virgin" soils are not as rich as reported. In Canada, for example, the prairie soils grow as good crops of wheat as do the highly farmed fields of England, but elsewhere most of the soils treated as if they were fertile virgin soils produce relatively low wheat yields.

Soils that appear naturally barren are often deficient in water supply, although excess of water is also a cause of sterility. A class of soil very common in old farmed districts is the exhausted soil. Wheat can be grown for many years in succession on the same land with a minimum amount of manure, but the yield per acre gradually falls. Other crops reach a state of exhaustion at a much greater rate, although it has been found in many cases that the returns can be maintained by appropriate treatment and by application of the right fertilizers.

From the point of view of the Industrial Chemist, the fertilizers are by-products of industry which proceed to agriculture only to reappear in new forms of plant products, to again form part in some industrial enterprise. It is therefore convenient in this volume of the series to begin with a discussion of the fertilizers. These form a group of bodies whose values and classifications depend on the uses to which they are put rather than upon their origins.

For the purpose of studying the fertilizers it is necessary to consider more than one system of classification.

A useful general system will be to regard the fertilizer as a means of supplying a particular chemical element as follows :-

I. The nitrogen group.

2. The phosphorus group.

3. The potassium group.

There will be many fertilizers that fall into more than one such group. 
There will also be the need to consider a classification which is mainly physical as follows :-

I. Cementive or binding.

2. Opening or aerating.

And lastly we may have to consider fertilizers from a dynamic, rather than a static point of view, as in the following:-

I. Lasting.

2. Readily available to the plant.

3. Soluble in water and easily diffusible.

4. Stimulating and only suitable for top dressings.

5. Reactive, i.e. those that induce chemical or biological activity in the soil.

The purely chemical classification, depending as it does upon the most important chemical element present, is comparatively simple and devoid of ambiguity. In practice it is not quite so simple as it looks. Later we shall have to discuss cases where the use of a manure dependent for its value on one element produces ultimate effects which are best measured in terms of another element. Also in many cases the fertilizers are compound and contain more than one element of value.

The physical classification demands a knowledge of the soil to which the fertilizer is applied. But the ultimate physical effects resulting from the applications of the fertilizers are of a very varied kind, some even tending to destroy completely the proper physical condition of the soil unless some remedial measures are employed.

The power of a fertilizer to act quickly or slowly is a very important property. In some cases a rapid effect is desirable. For example, when a fertilizer is used as a top-dressing it must always be soluble, otherwise the action would be too slow. The case of applying such a fertilizer as dung to the surface of a permanent pasture might be considered a case of top-dressing, but this term is usually applied to the use of a soluble manure on a hay or corn crop when in fairly full growth, under which circumstance quick action is necessary. When a fertilizer is applied in the winter or period of little growth, a much less degree of solubility will suffice and it 
is often undesirable to use a fertilizer that readily dissolves in water. Very soluble manures may actually wash out of the soil before the plant can obtain its proper share of the nourishment.

In considering the actions of fertilizers on the plant and on the soil it is always important to remember that in no sense is such a series of actions a static matter. The plant itself is undergoing rapid chemical change and the soil is full of life. When a fertilizer is applied to the soil, chemical change begins at once and may go on for a long time. These chemical changes induce changes in the development and rates of growth of organisms in the soil from the common earth-worm down to bacteria. The equilibrium of the soil is upset and will only be re-established after an interval of time. In some cases this interval of time is short, but in others may last several years. In addition to the above, there are many secondary points of practical importance. A manure to be successful must be well distributed. A little consideration will at once show that the distribution of fertilizers is a difficult problem. There is no more important point in presenting any commodity to the consumer than placing it on the market in a uniform condition. The same point is just as true of the products of the field as of the factory. The soil is not by any means uniform by nature, and all efforts must be made to correct the irregularities and not intensify them by irregular applications of fertilizers. Soluble fertilizers have the great advantage that the rain distributes them automatically. Unfortunately the distribution by this means is only very slight in a horizontal direction although in a vertical direction it is much more complete. If we imagine a dressing of a hundredweight or so applied to an acre and that all the grains of the fertilizer are about one-tenth of an inch in diameter, then there would be about one such grain for each square inch. So that even if we had a perfect distributing machine, the distribution of such a fertilizer would leave much to be desired, since the root hairs of the plant are very small and numerous, and if many of them fail to get their share of plant food there is sure 
to be a weakness in the complete plant. Very much finer division is in practice found to be necessary. Some years ago the author demonstrated on a small scale that the usual standard sieve for basic slag was about right. (See p. 25.) When a slag was sieved and only those parts which refused to pass a sieve with thirty meshes to the linear inch were used as a dressing on grass land, no visible benefit resulted. When the sieve was finer and contained sixty meshes to the linear inch, the part that refused to pass produced a slight effect. When the sieve contained one hundred meshes to the linear inch, the part that refused, produced about half the effect of a complete slag. When the part that passed the sieve with one hundred meshes to the linear inch was applied to the grass land the effect was good; and when still finer sieves were used, no further improvement could be observed. In short, so far as basic slag on grass land is concerned, it may be taken as certain that fertilizers of the order of fineness, represented by just passing a sieve of the standard dimensions, are at their maximum efficiency. As already stated above fertilizers do not travel laterally in the soil, and in consequence even the soluble manures require some degree of fine grinding, but not to the same extent as in the case of the insoluble fertilizers.

When the fertilizer is applied, whether by hand in broad casting, or whether by a drill or other machine, it is desirable that the fertilizer should be not merely finely divided, but should also be in a dry condition. If the fertilizer is apt to form lumps, all the energy expended on fine grinding is wasted. Materials quite insoluble in water are not likely to give trouble in this respect, but those that dissolve may pick up moisture from damp air, and the surface of the grains become coated with a strong solution, only to dry up later in an atmosphere less moist, and thus cause the manure to become caked. It is a well-known fact that dusty mercury globules do not coalesce, and, similarly, it is a common household recipe to add a minute amount of rice flour to salt, so that it does not cake in damp weather. The sticky grains become coated with a fine dust, and are no longer 
able to cohere. Many forms of organic matter have a great capacity for absorbing water. This can be explained by reference to some tamiliar instances. Ground linseed cake will absorb about sixteen times its weight in water, peat moss litter about ten times its weight of water, and gelatine about twenty times its weight of water, whilst the material known as agar, or dried seaweed, is capable of retaining up to two hundred times its weight of water. The effect of any manures of this class upon the water supply of the soil is very pronounced. It will readily be seen that a material which provides water for lasting out a droughty period will confer a great advantage, and an equal advantage will result from a material which will prevent surface washing of the soil, by absorbing water during excessive rainfall. It is quite impossible to find out, except by experiment on the soil itself, what the value of any particular organic manure may be as regards the water-holding capacity. On very light soils the value will be due to retention of water, and cohesion of the sandy particles. On heavy soils the value will be due to the prevention of surface washing, by absorption of excessive rain, opening up the soil to air, and making the soil lighter for spade or plough to work.

An important point in the consideration of the use of fertilizers is the depth of penetration of the manures. Nitrates will penetrate to practically any depth. Ammonia compounds are entirely precipitated on the surface, and do not ustrally go more than two or three inches deep. Amides, such as urea and asparagine, penetrate perhaps to about ten or twelve inches. Soluble albuminoids penetrate to a depth midway between ammonia and amides. The insoluble albuminoids filter out on the surface. Phosphates are precipitated near the surface and rarely reach a depth of eight inches. Super-phosphate will be found for the most part at a depth of about four or five inches. Basic slag does not readily penetrate more than about one inch. Potash penetrates a little further than ammonia. This, of course, applies only to the immediate action. Secondary actions of all these materials will alter their position. 
Much of the disfavour into which so-called chemical manures fell in the early efforts to use them was due to injudicious and ignorant use. Probably no one would to-day make the same mistakes, but to a lower degree similar mistakes are still made. Very large areas of land in many countries are urgently in need of dressings of lime, because all kinds of fertilizers have been used in the past, with only a partial recognition of the important fact that most fertilizers remove lime from the soil. In the early days of intensive farming lime was used generously and often excessively. No doubt the disastrous effects of excessive use of lime made farmers rush to the opposite extreme, and use far too little lime. To-day we have to make up for past neglect. Even on soils which stand over chalk or other calcareous geological formations, lime is not infrequently advantageous.

All life depends on a delicate balance of chemical reactions, and although living things have a considerable power of resistance, if one is merely considering them from the point of view of the struggle for existence, yet when one is considering the growth of plants from the point of view of obtaining a paying crop, one cannot permit them to struggle, one must supply them, with the balance which they require. Unfortunately, this problem of the balance of the ingredients needed by the plants has received too little attention. The way in which the balance of a soil may be upset is shown in the following graph, which is taken from a paper by the author, read to the Society of Chemical Industry, May 3I, I9I5. This graph shows, with regard to the two constituents selected for illustration, that when the fertilizing dressing of magnesia or manganese increased, an increase in crop occurred at first, but after moderate percentages of the fertilizing ingredients had been used, a decrease in crop occurred. There are any number of illustrations of the same law, in other subjects dealing with the life of plants or animals.

All the more recent books to be found in the bibliography, have some reference to the principle that the balance of the ingredients is an important proposition. 
The plant products thus obtained are rarely fit for immediate use and have to undergo fu1ther manipulations. Sometimes crops are fed to cows which give milk which

GRAPII.

Correlation between the Hay Crop and $\mathrm{MgO} \%=x$ or $\mathrm{MnO} \%=0$

Below Jean \%.

Above Mean \%.

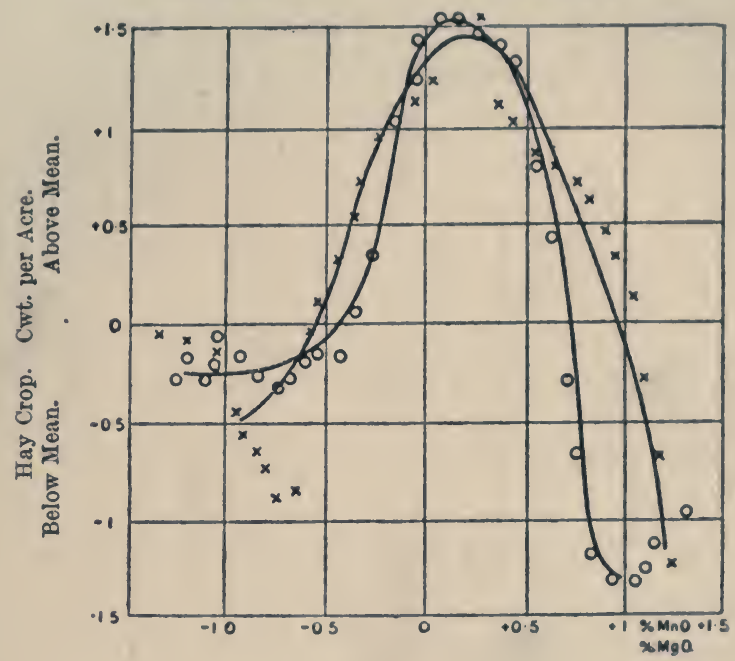

is turned into cheese, or other products. There is therefore hardly any ultimate limit to the subject of plant products, and sooner or later they all appear in some other volume of this series.

\section{REFERENCES TO INTRODUCTION}

Daubeny, "Roman Husbandry" (Oxford) (from Columella and Virgil). Davy, "Agricultural Chemistry" (Griffin) (I 802-12).

Liebig, "Chemie für Agricultur u. Physiologie" (Vieweg) (about I 840). Boussingault, "Agronomie, Chimie Agricole et Physiologie" (MalletBachelier) (about I 850 ).

Collins and Hall, "The Inter-relationships between the Constituents of Basic Slag," Journ. Soc. Chem. Ind., May, 1915, p. 526. 


\section{PART I.-THE FERTILIZERS}

\section{SECTION I.-NITROGEN GROUP OF FERTILIZERS}

THE nitrogen fertilizers have certain properties in common. Most fertilizers in this group contain the element nitrogen in a fairly available form and do not contain any large amount of either phosphorus or potassium. They all tend to stimulate the active growth of the plant especially as regards the green parts thereof. A general tendency of this group is to delay ripening, a result not always beneficial. If applied too freely they may cause corn to "lodge," that is to grow too big and heavy for the stem to properly support the ears. In the case of plants bearing fruit the result of too liberal dressings of nitrogenous fertilizers may result in too large development of leaf or woody stem with a resultant loss of fruit. Used with discretion this group of fertilizers provides one of the most valuable means of obtaining large increases in the crops produced.

That there is a considerable degree of interchangeability between the members of this group may be seen in Table I.

Table I.-Nitrogen Stimulants.

Results of field experiments on grain. Crop per acre.

\begin{tabular}{|c|c|c|c|c|}
\hline \multirow{2}{*}{\multicolumn{2}{|c|}{ Manure. }} & \multirow{2}{*}{$\begin{array}{c}\text { Order } \\
\text { of } \\
\text { merit. }\end{array}$} & \multicolumn{2}{|c|}{$\begin{array}{l}\text { Average of thirteen } \\
\text { experiments. }\end{array}$} \\
\hline & & & Grain. & $\begin{array}{l}\text { Straw } \\
\text { and chaff. }\end{array}$ \\
\hline I. No manure ... & .. & - & $\begin{array}{l}\text { lbs. } \\
2196\end{array}$ & $\begin{array}{l}\text { cwts. } \\
27 \frac{3}{4}\end{array}$ \\
\hline 2. Super-phosphate and potash & .. & 6 & 2260 & 29 \\
\hline 3. No. 2 and nitrate of soda.. & . & 5 & 2595 & $35 \frac{1}{4}$ \\
\hline 4. No. 2 and sulphate of ammonia & $\ldots \quad \ldots \quad \ldots$ & 2 & 2668 & 37 \\
\hline 5. No. 2 and calcium cyanamide (e & early application) & 4 & 2680 & 35 \\
\hline 6. No. 2 and nitrate of lime .. & $\therefore \quad \cdots \quad \ldots$ & I & $28 I 6$ & $38 \frac{1}{2}$ \\
\hline 7. No. 2 and calcium cyanamide ( & (late application) & 3 & 2697 & $35 \frac{1}{4}$ \\
\hline
\end{tabular}


It will be seen that the effect of the nitrogenous fertilizers is in all cases a very marked one, that some give better results than others, but the different forms of nitrogenous manures will not always fall in this order, although for cereal crops it may be expected that something like this order will be maintained.

The general subject of the nitrogen fertilizers cannot be discussed without some reference to the possible alternate scheme of producing the nitrogen needed on the farm by indirect means, although this subject can be better discussed in Part IV.

By the use of phosphatic manures it is possible to develop the growth of leguminous plants which indirectly extract nitrogen from the air. The nitrogen so extracted will not all be sold off as crop, some will remain in the soil as the roots of the leguminous plant. When the leguminous plants are fed to stock, most of the nitrogen will find its way into the manure heap and, provided that care be taken, thence to the soil. Such accumulations will be slow acting and can never entirely replace the quick-acting nitrogenous fertilizers; nevertheless great economy of nitrogenous fertilizers is possible by these means.

At the present time war has drawn attention to many methods for the fixation of atmospheric nitrogen. When the war is over and the demand for explosives slackens, the synthetic nitrogen compounds will be more extensively used for agricultural purposes.

Sulphate of Ammonia.-Sulphate of ammonia is a product of gas works and coke ovens. The amount obtained in practice is by no means what could be obtained under theoretical conditions; for example, the ordinary gas retort gives little more than twenty pounds of sulphate of ammonia per ton of coal carbonized, whereas theoretically, one hundred and fifty pounds of sulphate of ammonia per ton of coal carbonized might be obtained. There are, therefore, great possibilities of an increase in the amount of sulphate of ammonia available for agricultural purposes. Stulphate of ammonia has for many years past been obtainable 
at prices varying from about $f .9$ to $£ 20$ per ton at British ports. Roughly speaking $f_{1} 4$ per ton is considered a general average of English prices.

The demand for sulphate of ammonia for agricultural purposes is almost certain to increase, as the need for it is better recognized. That the value of, say, $£ \mathrm{I} 4$ per ton is, from the user's point of view, not an unreasonable one, may be judged from Table 2, which is based on recent field experiments and shows the average increase in the various crops with the value of such increase that may be expected from the use of I cwt. of sulphate of ammonia per acre, costing about seventeen shillings. The crops have been valued at low prices.

\section{TABLE 2.}

Increase due to I cwt. sulphate of ammonia costing I $7 s$.

\begin{tabular}{|c|c|c|c|c|c|c|c|}
\hline Wheat .. & 4 bush. at $55 s$. per qr. 504 & & & $\begin{array}{l}s . \\
7\end{array}$ & $\begin{array}{l}d \\
6\end{array}$ & $\mathcal{E}$ & s. \\
\hline Wheat Straw.. & 5 cwt. at 4 os. per ton & & O & ro & 0 & $\mathbf{I}$ & I7 \\
\hline Barley .. & 6 bush. at 50 s. per qr. $44^{8}$ & & I & I7 & 6 & & 6 \\
\hline Barley Straw.. & 6 cwt. at $30 s$. per ton & .. & o & 9 & o & 2 & 0 \\
\hline Oats ... .. & 7 bush. at 30 s. per qr. 336 & s. & I & 6 & 3 & & \\
\hline Oat Straw & 7 cwts. at 40 s. per ton & .. & o & $I_{4}$ & o & & \\
\hline Rye Grass Hay & ro cwts. at roos. per ton & .. & & & & 2 & Io \\
\hline Meadow Hay.. & $8 \mathrm{cwts}$. at $90 \mathrm{~s}$. per ton & .. & & & & I & 16 \\
\hline Mangolds .. & 32 cwts. at i2s. $6 d$. per ton & .. & & & & I & $\mathbf{o}$ \\
\hline Potatoes & 20 cwts. at $60 s$. per ton & . & & & & 3 & o \\
\hline
\end{tabular}

Consideration of the foregoing figures shows that there is ample justification for the liberal use of reliable manures.

For practical purposes sulphate of ammonia may either be applied by itself or in mixtures. Probably most of the sulphate of ammonia actually used is applied in mixtures, either made by the farmer himself or purchased ready made from the manufacturer.

Certain of these mixtures are very practicable and useful, others are not desirable, and others must be avoided at all costs.

One of the commonest and most useful mixtures is compounded from sulphate of ammonia and super-phosphate. This mixture has the following special advantages:-both manures are moderately quick in action; neither are instantly available for plant life. 
In both cases changes have to take place in the soil before the constituents of the fertilizer are suitable for absorption by the plant; indeed, in both cases a water culture of either super-phosphate or sulphate of ammonia, or both together, would be absolutely injurious to the plant, and the plant would probably refuse to grow altogether. After, however, these materials have acted upon the soil they are rendered suitable to the plant's needs.

When sulphate of ammonia acts upon the soil a complete chemical change takes place. This change can be easily demonstrated so far as the broad effects are concerned by the following simple experiment :-A couple of glass tubes, about $2 \frac{3}{4}$ or 3 inches in diameter, and about a foot in length, are partially closed at one end with cork and cotton-wool, and a depth of 6 or 8 inches of soil placed in the tubes. Into one tube is poured some distilled water $\$ 9$ ps to perceive the effect of plain water upon the soil isuto the gther tube is poured a solution of sulphate of amimonia in mater. If a quantity of sulphate of ammonia 4 eishing about onetenth of a gramme be used for one of these tapes it would correspond to an application of $2 \mathrm{cwt}$. sulphate of ammonia per acre, a quantity comparable to practice.

A litre of water poured on to the quantity of soil mentioned above would correspond to a rainfall of about ten inches.

If the drainage from the two tubes be now collected, the addition of a small quantity of "Nessler's," solution will give a coloration due to the ammonia, and it will be at once observed that whilst the original manure employed shows a large amount of ammonia present, the drainage from the manured soil only shows a fraction of that amount. The distilled water itself will be found to have washed a little ammonia out of the soil, unless the soil chosen was a particularly poor one. We perceive at once from such an experiment that the ammonia has in some way been removed from aqueous solution, or in other words, the ammonia has been fixed by the soil. These fixations of fertilizer ingredients are always partial reactions which follow the 
chief chemical laws of mass action, so that the soil water will always take away some ammonia from the soil.

After the ammonia has become fixed in the soil it still has to undergo further changes. These changes are, however, not purely chemical ones, but are dependent upon bacterial action, and are not so easily demonstrated on the lecture table or in the laboratory. They require an elaborate experiment on the field itself. Such elaborate field experiments have been carried out at Rothamsted.

To return to our experiment with two tubes, another point that can be easily investigated by such an experiment is to examine the fate of the sulphuric acid part of the sulphate of ammonia.

By the use of barium chloride we can see at once that plain water removes a noticeable amount of sulphuric acid from the soil, and that the drainage from the manured soil practically amounts to the sum of the other two quantities, namely, that which sulphate of ammonia contains and that which water washes out of the unmanured soil. Another very important result that can be seen from this experiment is the effect of the sulphate of ammonia on the amount of lime in the soil. The sulphuric acid part of the sulphate of ammonia combines with the lime in the soil and the two go out together as calcium sulphate. A test with ammonium oxalate on the drainage from the two tubes will show at once that the lime lost to the soil by drainage is very much greater when sulphate of ammonia is applied than when the soil is unmanured. In common agricultural language, sulphate of ammonia exhausts the soil of its lime. The demonstration of this point on a large scale in the field has been very admirably shown in the researches of the Royal Agricultural Society in their experimental farm at Woburn. In certain plots of barley continuous application of sulphate of ammonia results in turning a light but good soil into a mere desert, which grows nothing at all, except an occasional weed. When, however, soil, which has been rendered infertile by deliberate over-manuring is subsequently treated to a dressing of lime, the fertility is recovered, and crops 
grow once again. The success of application of sulphate of ammonia is, therefore, intimately connected with the amount of lime which is either naturally present in the soil, or has been added to the soil.

Without the lime, sulphate of ammonia will not undergo those changes which are necessary. The amount of sulphate of ammonia which can be applied to the soil may be put down roughly as one or two hundredweight per acre.

For the purpose of enabling a wheat crop to get over the dangerous period either at the beginning or the end of the winter a top dressing of sulphate of ammonia is most useful. For such purposes as top dressings only about half a cwt. of sulphate of ammonia need be used at one time, as it is not difficult to give a second dressing of $\frac{1}{2}$ cwt. later on should it be found necessary. The farmer will judge for himself from the look of the crop whether such an application is desirable or not. Should the plant appear yellow and sickly it is a safe thing to give a top dressing. Another great use of top dressings of sulphate of ammonia is to enable a growing crop or slow crop to get through a droughty period when half grown. As explained in Part III., Section I., an application of fertilizer may be equivalent to an application of water, and of the manures which can be used in this way sulphate of ammonia takes a very important position. Such small dressings as are here referred to undoubtedly present some difficulty in their even distribution, but the sulphate of ammonia can be mixed with a small quantity of dry earth or ashes, but not with lime or any substance containing lime.

Use of sulphate of ammonia demands some knowledge of the general physical and chemical properties of the substance. Conmercial sulphate of ammonia is a very finely crystallized substance, having a slight tendency to stick together, owing to the presence of two or three per cent. of water, and a few tenths of a per cent. of free sulphuric acid. It does not, however, exhibit any great tendency to cake, but may need to be broken by a spade before use. It is very easily soluble in water, and the common article will just redden 
a piece of blue litmus paper. When heated it gives up the small amount of water which it contains, and then proceeds to undergo a regular and complete decomposition. At first sulphate of ammonia decomposes into ammonia and ammonium hydrogen sulphate, then splits off some sulphur tri-oxide, which reacts as an oxidizing agent, giving off free nitrogen and sulphur dioxide. The sulphur dioxide, together with the water, and some of the free ammonia, then again combine and produce ammonium hydrogen sulphite. These reactions can easily be perceived when ammonium sulphate is slowly heated in a test-tube. The water coming off will at first condense in the colder and upper part of the test-tube; further heating results in giving off a smell of ammonia, and in the formation of a sublimate in the colder part of the test-tube. If, after cooling, one or two drops of hot water be added to the contents of the testtube, a smell of sulphur dioxide is at once perceived, because the ammonium hydrogen sulphite is not a very stable body, but dissociates with hot water. The ultimate result of heating sulphate of ammonia is that the water, ammonia, and sulphuric acid are driven off, and nothing left behind but some mineral impurity which is mostly a trace of soil or iron oxide.

When sulphate of ammonia comes into contact with an alkali or strong base, the sulphuric acid combines with the alkali or base, and the ammonia is set free and diffuses into the atmosphere. It is for these reasons, that sulphate of ammonia should never be mixed with lime, wood ashes, or basic slag. However, very few soils are so calcareous that the clay and humus do not greatly preponderate over the lime, so that the ammonia is more readily fixed by the clay and the humus than it is driven off by the lime materials. Sulphate of ammonia will take three weeks of very good weather to nitrify all the ammonia added to the soil. Nitrification, though very slow in the winter, produces some nitrate which is lost by drainage, though such loss is not sufficient to condemn the winter application of sulphate of ammonia. On general grounds sulphate of ammonia 
must be regarded as a manure to be applied shortly before it is needed. It is not so quick in its action as nitrate of soda or nitrate of lime, but is a great deal quicker than the organic nitrogen manures. Its stimulating effects on the plant are seen in the large development of the leaf. It is therefore especially valuable for the production of green stuff, and is deservedly very popular among market gardeners and all intensive cultivators. For the purpose of fruit growing it is not such a suitable manure, since some fruits do not develop well if the plant is too vigorous and rank in its growth. Such prolific fruits as gooseberries must be excepted from this general statement (see p. I66).

Sulphate of ammonia, in a very crude form, occurs in soot (see pp. 66 and 92).

Ammonium Chloride.-Of the other compounds of ammonia which have been used as fertilizers ammonium chloride is probably the most important. Ammonium chloride, sal ammoniac, or muriate of ammonia, has always been used in the Rothamsted experiments, doubtless because at the date when these experiments were started it was by no means a foregone conclusion which particular ammonia salt would prove most practicable. When ammonium chloride is used as a manure many of the soil reactions closely resemble those of the sulphate. The ammonia is fixed in the soil, the chlorine carries away calcium (lime), so that the ultimate result in the soil is the same. The actions of sulphates and chlorides on plant life are nearly but not quite identical, though these points can better be discussed under the heads of the crops concerned (see Part III.). At the present time there does not seem any likelihood that ammonium chloride will be a practicable fertilizer.

Ammonium Nitrate.-Ammonium nitrate is a very deliquescent substance, and is for that reason not very suitable as a fertilizer. Its very high percentage of nitrogen, however, might make it valuable where transport facilities were very poor. Though, at present this does not seem a very practicable manure, it would certainly have the

D. 
advantage that there is nothing in it of an objectionable character.

Ammonium Carbonate.-Ammonium carbonate itself is too volatile, but ammonium hydrogen carbonate is a light, dry powdery substance, which only slightly smells of ammonia. At present no serious attempt has been made to produce ammonium bi-carbonate for use as a fertilizer, but since the gas works have already prepared directly a strong liquid ammonia there does not seem any reason why they should not manufacture ammonium hydrogen carbonate, as, of course, it is obvious that they produce carbonic acid in quantities many thousands of times more than is needed for this purpose. At present, however, this also is not a practicable fertilizer.

Nitrate of Soda.-Nitrate of soda chiefly occurs as a deposit in Chili, is mined, extracted with water, and recrystallized. The composition is fairly constant, containing rarely less than 93 per cent. pure nitrate of soda, or more than 97 per cent. pure. Of a large number of samples examined, over one half had between 96 and 97 per cent. pure nitrate of soda. As it is obtained exclusively from foreign sources it is imported by ship, and as a rule the shipments are of a definite known composition. Nitrate of soda does not lend itself very particularly well to mixtures. It can be mixed with basic slag, but such a mixture is not particularly useful, because nitrate of soda is very quick acting, and basic slag is very slow. It cannot be mixed at all satisfactorily with super-phosphates, since this mixture becomes somewhat heated and produces free nitric acid, which then distils out of the mass and condenses on the outer surface and thus rots the bags or sacks which may have been used for transport. The chief method of application of nitrate of soda to the soil is for a top dressing, as it need not undergo any chemical change in the soil before absorption by the plant. It is applied as a top dressing in the same way as sulphate of ammonia, and is among the quickest of all fertilizers. Nitrate of soda as sent to the farmer is not infrequently in large lumps, and requires to be broken up. Owing to its 
extreme solubility in water, it must be kept dry, and owing to its deliquescent properties it must be kept away even from moist air. If it becomes very damp it is likely to cake together and to need breaking up again before application. When applied to the soil a slight chemical change takes place. To a limited extent the soda in nitrate of soda and the lime in the soil change places with one another. Continuous application of nitrate of soda will therefore remove lime from the soil by drainage. Nitrate of soda does not, however, remove quite so much lime as sulphate of ammonia. Whilst sulphate of ammonia contains the relatively unimportant ingredient sulphuric acid, nitrate of soda contains the equally unimportant ingredient soda. The former, of course, produces an acid reaction, and the latter produces an alkaline reaction. Whilst the sulphate of lime produced from sulphate of ammonia readily drains away from the soil, in the case of the soda the loss by drainage is less rapid. The soda acts chiefly upon the clay and humus of the soil, and forms a colloidal solution, which results in the transfer of the fine clay particles from the surface to the sub-soil, reducing the fertility of the surface soil, whilst the sub-soil becomes choked with material more or less impervious to water. From the above causes both sulphate of ammonia and nitrate of soda, when used in large excess, as in the Woburn experiments, produce almost equally bad results. The cure for these objectionable effects from nitrate of soda lies in the use of lime or sulphate of lime. The former can be supplied in basic slag, and the latter in super-phosphates. The chief effect of the use of nitrate of soda upon the crop grown is to stimulate the production of green stuff. Hence it is of particular value for such crops as gooseberries, cabbages, and turnips. Like sulphate of ammonia, it may also be used as a top dressing for application either to wheat or to hay. Both of these manures, sulphate of ammonia and nitrate of soda, are much used in intensive forms of tropical agriculture, on such crops as tobacco and coffee. The impurities in nitrate of soda include potassium iodide, potassium iodate, and potassium 
perchlorate. It frequently happens that there is quite enough iodine to produce a smell of that element, and traces of perchlorate are also common. Cases have been recorded where these impurities have reached sufficient amounts to produce prejudicial effects on the crops grown, but the event is too rare to be of any practical importance. The effects of rare elements like iodine can be studied in the Royal Agricultural Society's Reports.

Nitrate of Lime.-In I8g8 Sir William Crookes read his Presidential address to the British Association at Bristol, calling attention to the possible diminution in the world's supply of wheat, and urged the necessity of the manufacture of nitrates directly from the air. It is taking a long time to reach the condition of affairs he described, though the world's shortage of wheat is certainly already appearing. 'The supply of nitrate of soda has not shown the decrease anticipated; on the other hand, sulphate of ammonia has proved to be more plentiful, but, nevertheless, some nitrate made from the air is now a practical fertilizer and after the war is over may come into more general use. The chief difficulty in using nitrate of lime is due to its deliquescent properties ; nitrate of soda is bad enough in this respect, but nitrate of lime is worse. Nitrate of lime has to be kept in casks, which are by no means convenient to carry to the field. When nitrate of lime is broadcast by hand it is extremely unpleasant to the workers, since small dust particles settle upon the workers' faces, and by dissolving in traces of sweat, produce a stinging strong solution. Nitrate of lime can be used in much the same way as nitrate of soda. It is very quick acting, should only be used as a top dressing, is instantly available, and is easily washed out of the soil. When nitrate of lime is mixed with a small proportion of sulphate of ammonia, a very fine dry breadcrumb-like powder is obtained, which is very convenient to handle. Nitrate of lime cannot be mixed with super-phosphate (see p. 35), and admixture with basic slag would be of little value. One of its great advantages lies in the fact that it has no useless ingredients; the whole of the lime and the 
nitrate can be easily absorbed by the plant, and nothing is left behind in the soil, either good or evil. It therefore is especially suited to conditions of drought or bad drainage where undesirable salts accumulate and cannot be removed. I ike nitrate of soda, it is quite unsuitable for winter application.

Nitrate of Potash.-Nitrate of potash, or potassium nitrate, is one of the earliest artificial manures. In the vicinity of old village sites nitre earths are of comparatively frequent occurrence, especially in India and Esypt. In India the collection and working of these is an old-established industry. The nitre earths, which have accumulated as the result of the decomposition of organic nitrogenous waste, are put into small pits with false bottoms and extracted with a minimum possible quantity of water. The solution obtained is then crystallized, and crude nitrate of potash obtained. Both the original nitre earths and the waste from this crude manufacture are used regularly for ordinary manuring of crops. In some localities also, considerable accumulations of nitrate of potash occur in the well waters, and some of the districts in India which grow tobacco crops are situated in areas where there are many nitre wells.

The manufacture of pure nitrate of potash from the above crude materials has been brought to such a state of perfection that the waste contains very little potash or nitric acid.

Nitrate of potash is, of course, a very valuable manure, as it contains two elements of value to the plant. When added to the soil the potash combines with the clay and humus and becomes fixed, and the nitric acid combines with the lime in the soil (see also Potassium Manures, p. 37).

Calcium Cyanamide. - The manufacture consists, firstly in producing calcium carbide, which is made in an electric furnace from lime and coke. The calcium carbide is then heated, and nitrogen passed through it, when calcium cyanamide and graphite are produced. The material put upon the market contains about 50 to 55 per cent. calcium cyanamide, 25 to 30 per cent. lime II to I 2 per cent. graphite, 
and 2 to 3 per cent. silica. The amount of nitrogen varies from $I 7$ to 20 per cent. Calcium cyanamide, when kept in store, slowly absorbs water from the air, so that it increases in weight. In consequence of this fact the percentage of nitrogen decreases at the rate of $I$ per cent. in two or three months, but the owner does not thereby lose anything. At the same time a small amount of decomposition does take place, and traces of ammonia are given out into the air. Calcium cyanamide in itself is no use to the plant, and when acted upon by the water in the soil it will produce the poison di-cyanamide, which will slowly decompose into ammonia, and then nitrify. It is only suitable for application some time before sowing. It is a slow-acting manure, and is quite unsuited to top dressing. It can be mixed with basic slag, but not with super-phosphate or with sulphate of ammonia. The amount of lime present is generally beneficial, and the graphite is absolutely harmless. At first calcium cyanamide will act as a poison; it will therefore have the value which will be alluded to again under the head of the "Partial Sterilization of Soils" (see p. 90).

The Organic Nitrogen Fertilizers.-Fish refuse, fish meal, or fish guano, is one of the most important in this group.

Refuse fish is often used locally by farmers, but the manufacture of fish meal and fish guano are definite industries in connection with fisheries. The best qualities are used only for feeding purposes, but the other qualities are applied to the soil. A very large proportion of the fish guano in Great Britain comes from herrings. The heads, tails, and guts that are discarded in salting the herrings are dried, and then the fat extracted by petroleum spirit. The resulting material when used for fish guano contains about 9 to I2 per cent. nitrogen, 3 to 5 per cent. of phosphoric acid, and about I per cent. of potash. The amount of oil should not exceed I to 2 per cent. In other parts of the world other systems are often in use. In some parts of America the fish is boiled, the fat skimmed off, and the resulting mass dried and used as a manure. In India much refuse fish is dried on the beach, 
and then sold as a fertilizer. Whilst fish guano is of very varied composition, the product of any one factory is often quite constant. The average of a large number of samples obtained from North Shields has been:-nitrogen 8.0 per cent. $\pm 0 \cdot 2$, phosphoric acid $=5^{\circ} 9$ per cent. \pm 0.8 , potash $=I \cdot I$ per cent. $\pm 0^{\circ} 3$. The nitrogen is so much higher in amount and fertilizing value than the other ingredients that this fertilizer may be looked upon as belonging to the organic nitrogen group. Like all the members of this group, fish guano is much slower in its action than sulphate of ammonia or nitrate of soda. Its decomposition in the soil depends upon living things, from bacteria upwards. Moisture, warmth, and lime in the soil greatly facilitate its action. In addition to its purely.chemical value the physical properties must be considered (see p. 68).

An objection to fish meal, not uncommon to the whole of this group, is that it is sometimes too attractive to birds, or even four-footed beasts. Crows have been known to pull it out of the soil almost as fast as the farmer had put it in, and in India it has sometimes induced the wild pig to root it out and trample the field. For cold situations, or for late application, or for top dressing this manure is inferior to sulphate of ammonia or nitrate of soda.

Dried Blood.-Dried blood is generally only the clot, and not the entire blood, as the boiling down of big quantities of blood is a difficult problem. Fresh blood, when obtainable, can of course be used also. Blood decomposes in the soil with great rapidity. Dried blood, as a rule, contains from 9 to I2 per cent. nitrogen.

Hoofs and Horns. - These are the product of the slaughter-house, and are much used by the manufacturers of artificial manures. They contain from 12 to 16 per cent. of nitrogen. The raw horn swells very slowly in the soil, and acts slowly, but if horn be steamed it swells up quickly in moist soil, and produces a moderately quick-acting fertilizer. This material must, in any case, be very finely ground.

Wool Waste, Shoddy, Feather Waste, Feather Dust, and Silk Waste, are all waste products of a fibrous and 
bulky character. They are much appreciated by the Kentish hopfarmers, and are particularly adapted for dry, gravel, and chalk soils. They do not, however, decompose at all readily in the soil, and their beneficial action is probably quite as much physical as chemical.

Damaged Cakes. - There are some cakes obtained by pressing oil seeds which are not suited for cattle feeding. To animals castor cake is distinctly poisonous and rape cake is very bitter and distasteful. Further, some meals normally of value for cattle feeding have become accidentally damaged by fire, water, or mould. All of these materials come in usefully as fertilizers for the soil. Part of their value depends upon secondary effects, independent of the percentage of nitrogen, which will vary from 4 to 7 per cent. Some of the least edible, such as castor and rape, may very possibly injure wireworms or other pests. Linseed meal (see p. I36) is stated to be eaten by wireworms, and then by swelling inside them cause them to die. These materials decompose fairly quickly in the soil. Mowha cake contains saponin (see p. I45), and is used to remove earthworms from golf greens.

Meat Meal and Refuse from Meat Extract Works. - These contain usually about 5 to 8 per cent. nitrogen, and Io to I 5 per cent. phosphoric acid. Their action in the soil is very similar to fish and blood. The members of this group of fertilizers stand midway in their action between " Chemical Manures " and farmyard manure.

\section{REFERENCES TO SECTION I}

Russell, "Artificial Fertilisers, Their Present Use and Future Prospects," J. Soc. Chem. Ind., I9I 7, p. 250.

Hendrick, "Field Trials with Nitrogenous Manuring," J. Soc. Chem. Ind., I9I I, 523.

Special Leaflet No. 57. Board of Agriculture.

Voelcker, J. Roy. A gric. Soc. Eng., 1904, 306; I916, 244.

Russell, "Manuring for Higher Crop Production," p. 7 (Camb. Univ. Press).

Hobsbaum and Grigioni, "Production of Nitrate of Soda in Chile," J. Soc. Chem. Ind., 1917, p. 52.

Kilburn Scott, "Production of Nitrates from Air, with special reference to a New Electric Furnace," J. Soc. Chem. Ind., I915, p. II3. "The Manufacture of Nitrate of Ammonia," Chem. News, I917, p. I75.

Lamb, "The Utilization of Condemned Army Boots," J. Soc. Chem. Ind., I9I7, p. 986. 


\section{SECTION II.-THE PHOSPHORUS GROUP OF FERTILIZERS}

THE phosphorus group of fertilizers consists chiefly of the following compounds:-Mono-calcium phosphate, $\mathrm{CaH}_{4} \mathrm{P}_{2} \mathrm{O}_{8} \cdot \mathrm{H}_{2} \mathrm{O}$, which is easily soluble in water, very deliquescent, and strongly acid; di-calcium phosphate, $\mathrm{Ca}_{2} \mathrm{H}_{2} \mathrm{P}_{2} \mathrm{O}_{8} \cdot 4 \mathrm{H}_{2} \mathrm{O}$, which is slightly soluble in water, and is practically neutral to litmus paper; tri-calcium phosphate, $\mathrm{Ca}_{3} \mathrm{P}_{2} \mathrm{O}_{8}$, a rather indefinite compound, much less soluble in water, but attacked to some extent by carbonic acid; tetra-calcium phosphate, $\mathrm{Ca}_{4} \mathrm{P}_{2} \mathrm{O}_{9}$, which has been found in basic slag; apatite, $\mathrm{Ca}_{5}\left(\mathrm{PO}_{4}\right)_{3} \mathrm{~F}$, which is very insoluble in water; and some complex compounds, which are both phosphate and silicate, occurring in basic slag. As, with one exception, these materials are not very soluble in water, it is necessary that most of the phosphatic fertilizers should be very finely ground. In the case of basic slag the commonly recognized standard of fineness is the ability to pass a sieve containing I00 wires to the linear inch, or 10,000 meshes per square inch. This sieve is often used for other fertilizers as well. Small experiments conducted at Cockle Park, the Northumberland County Council experimental farm, showed that this degree of fineness was about correct. Those portions of phosphatic manures which only passed sieves much coarser than the above had little influence on the development of clover, whilst phosphatic manures, which were so finely ground that they could pass a sieve with 200 wires to the inch, showed no appreciable advantage over the standard. Special distributors have been constructed to assist in spreading these manures over the land in an even 
manner. Broadcasting these very fine powders is troublesome in windy weather. Whether these phosphatic manures happen to be soluble in water or not, they very quickly become insoluble in the soil. The soluble compounds attack the lime and ferric hydrate in the soil and form compounds insoluble in water. There is, therefore, no appreciable loss to phosphatic fertilizers through drainage. At Rothamsted, all the phosphates added during the preceding fifty-five years is accounted for in Table 3 :-

\section{TABLE 3 .}

Phosphorus Balance Sheet, Hall and Amos.

\begin{tabular}{|c|c|c|c|c|c|c|}
\hline \multirow{2}{*}{$\mathrm{P}_{2} \mathrm{O}_{5}$ lb. per acre. } & & & \multicolumn{2}{|c|}{ Broadbalk plots. } & \multicolumn{2}{|c|}{ Hoosfield plots. } \\
\hline & & & 5. & 7. & 2. & 4." \\
\hline Supplied in manure .. & . & .. & 3960 & 3810 & 3390 & 3390 \\
\hline Removed in crop & .. & $\cdots$ & 790 & 1370 & 1200 & 1240 \\
\hline $\begin{array}{l}\text { Balance expected in soil } \\
\text {, found in soil }\end{array}$ & $\begin{array}{l}\ldots \\
\cdots\end{array}$ & $\begin{array}{l}\ldots \\
\ldots\end{array}$ & $\begin{array}{l}3170 \\
3000\end{array}$ & $\begin{array}{l}2440 \\
2470\end{array}$ & $\begin{array}{l}2190 \\
2315\end{array}$ & $\begin{array}{l}2150 \\
2000\end{array}$ \\
\hline
\end{tabular}

It will be noticed that the very large amount expected to be left in the soil, estimating the difference between what was supplied and what was found in the crop, was almost exactly equal to the amount actually found in the soil. In two cases a little too much, and in two cases just too little, quite as close an agreement as one could possibly expect. These results, however, refer to a soil which, whilst very typical, is poorer than some agricultural soils. From soils that are very rich in phosphates, such as some garden soils, drainage does remove appreciable quantities of phosphate. The phosphates in the soil, whether natural or added by fertilizers, are attacked by the carbonic acid in the soil, and thereby rendered slightly soluble. The root hairs of a plant are probably permeable to such a solution of phosphates in water containing carbonic acid. When such solutions have entered the root, the acid in the root will take up the phosphate itself, and leave the carbonic acid free. The carbonic 
acid then diffuses out again into the soil, and dissolves more phosphate. Carbonic acid, therefore, acts as a carrier, and though the organic acids in the root are said not to pass out into the soil, they nevertheless have an important relationship to the solution of phosphates in the soil. The rate at which carbonic acid can be regenerated will depend upon the amount of acid in the root. Phosphates are especially valuable for stimulating root development, and it is probably for this reason that they are so important for the development of turnip seed in its early stages. Phosphates usually tend to accelerate the process of ripening. Phosphates are also very important in assisting nitrogen fixation in the soil, either directly by bacteria in the soil or indirectly by encouraging the growth of leguminous plants.

Basic Slag.-Basic slag is a by-product of the steel industries. The phosphorus contained in the ores, fuel, and lime accumulates in the pig iron, and is then transferred to the basic slag. The basic slag, therefore, represents a phosphorus concentrate, and may contain phosphorus equivalent up to 40 per cent. of tri-calcium phosphate. In addition to the phosphoric acid, basic slag also contains a total amount of lime, equivalent to about 40 per cent., with a few per cents. of magnesia and manganese, 6 to ro per cent. of iron, traces of vanadium and sulphur.

The lime is very largely in some state of combination, and the amount of lime that can be extracted by such a reagent as a solution of cane sugar is very small. Lime is needed by soils, as is explained in Part II., Section II., for several different purposes, (I) netrtralizing the acid of most manures (see p. 87), (2) assisting nitrification (see p. 86), (3) checking disease (see p. 73). For these miscellaneous purposes it has been found that calcium oxide, calcium liydrate, and calcium carbonate are approximately equivalent, calcium for calcium. The more basic calcium silicates are easily attacked by very feeble acids, and in this case calcium silicate is almost as good as other forms of lime. Looked at from the point of view of the farmer, to whom the application of lime to the soil is a well-known process, an equivalent to 
a dressing of lime may be provided by any of the forms of lime mentioned above. To endeavour to represent in some way the value of basic slag for replacing lime a conventional calculation is adopted. As a means of obtaining information of degrees of solubility, citric acid is commonly taken as a convenient standard, but there is no real theoretical reason why citric acid should be preferred to any other acid, though it is certainly convenient, and has amply justified itself in practice. In the case of basic slag it has become a recognized standard to extract the slag by shaking for half an hour with 2 per cent. citric acid solution, and to consider that the portion dissolved has a special value to the plant. If we take the lime that has been dissolved by citric acid, and deduct from that the lime equivalent of the phosphoric acid also dissolved, we shall obtain the lime soluble in citric acid, over and above what may be regarded as neutralized by the phosphoric acid. This figure is generally known as the available lime in the slag, and may fairly represent the relative ability of the slag to replace the ordinary operation of liming the soil. It is, of course, purely conventional. There is a good deal of evidence to show that the citric-acid soluble phosphate in a slag has a distinct value in pot experiments, and in all cases where the crop has only a short period of growth. There is also plenty of evidence to show that in the case of pasture such solubility is of little advantage. Citric solubility must, therefore, be regarded as a test of distinct value, in its proper place, but its importance can easily be exaggerated. The degree of fineness to which basic slag has been ground is also a very important point. The basic slag must be distributed much more completely than is necessary for a manure soluble in water, and this can only be achieved if the material is very finely divided (see p. 6). Basic slag must be put on early to get a full value. Probably the maximum result is obtainable about two years after application, but with slags of high citric solubility the maximum may be reached earlier. Soils containing much humus or peaty material are especially benefited by slag. To what extent this benefit is attributable 
to other constituents than the phosphorus is not really known. With a slow-acting fertilizer of this nature, which is a powerful root stimulant, a very considerable portion of the observed benefits may be quite secondary in their origin. The extraordinary change in the physical condition of a soil to which basic slag has been regularly applied must be seen before it can be believed, much less realized and appreciated. At Cockle Park, where this manure has been applied for many years on pasture, the final improvement of the soil has not yet been reached. Between 1897 and IgI 6 the result on the physical condition of the soil is shown by comparing a plot that has had no manure with a plot which has basic slag at intervals of about once in four years. The plot that has received no basic slag showed, on careful examination, in I9I6, no appreciable true soil at all. There was practically sub-soil up to the surface. On the other hand, the plot which had received frequent applications of basic slag now has ten or twelve inches depth of a good loam, and is apparently still increasing in depth, at probably a rate of about half an inch per annum. Such a profound change from a clay to a fibrous loam would of course explain any result, and it is, therefore, quite impossible to attempt to distinguish between the direct results of the addition of so much phosphorus and the indirect results which have benefited the plant by roundabout processes, which have certainly all originated in the application of the slag. As lime, by itself, has, on other plots, achieved but little result, one can only: conclude that the phosphorus is the ultimate origin of the observed fertility. Basic slag must be regarded as one of the more lasting manures, but it appears to become exhausted in time, and, generally speaking, an application once in four years will be necessary. The soils most suited are undoubtedly heavy clays and soils of a peaty character, whilst a sandy soil does not show such satisfactory results, unless it is manured at the same time with one of the potassium group of fertilizers (see p. 40). Basic slag has even been used with great success on very poor pastures on chalk, and seems to be one of the most generally useful 
of all the fertilizers. There are a considerable number of slags of low phosphorus content, and it is one of the most important problems before us to utilize these materials. In addition to basic slag there are acid slags produced in the steel industry which do not contain phosphorus. When they possess any value for applying to the soil it is probably due either to their lime content, or to the mere mechanical action of coarse material.

Mineral Phosphates.-Deposits of mineral phosphates are to be found in many parts of the world; indeed, on looking at the parts of the world where they have been found one cannot rasist the conviction that they have been found just where they have been most looked for, and that probably more extensive search will discover a great many new deposits. The historical "Cambridge Coprolites" have long since been worked out, and it is chiefly to foreign sources that we now look. Of these the Florida phosphates may be regarded as of the highest quality, containing about 75 to 80 per cent. of tri-calcium phosphate. North Africa and the Pacific Islands provide us with some materials of slightlylowergrade, whilst Australasia possesses some valuable deposits. These materials, if finely ground, can be applied directly to the land. They are, however, much less soluble than basic slag, and for direct application to the land it certainly seems a little contradictory for England to export basic slag and to import mineral phosphates. Where mineral phosphates have been systematically applied to pasture, in comparison with basic slag, some quite good results have been obtained. Satisfactory results have also been found when mineral phosphates have been used with the turnip crop. Nearly all the mineral phosphates actually mined are used for the manufacture of super-phosphate. The manufacture of this is described in other volumes of this series, and need only here be briefly alluded to.

The mineral phosphate, having been finely ground, is treated with sulphuric acid, and is run into a "den," where the reaction is completed. As the resulting material is apt to be sticky, it is sometimes, after breaking up, dusted 
over with dry, finely powdered mineral phosphate, which prevents the sticky grains from cohering. At some works the super-phosphate is dried and heated. In any case, it is extremely important to produce a fine, dry powder, which neither sticks to the hand in broadcasting, nor clogs the drill in machine application. Super-phosphate should always be kept in a dry situation, otherwise the skill and labour of the manufacturer will be wasted (see p. 6).

Super-phosphate, when stored, is apt to undergo a process known as reversion, by which some of the soluble phosphate once again becomes insoluble. The modern improvements in manufacture have reduced the risk of depreciation in value due to reversion during storage. Directly the superphosphate is applied to the land, reversion on a big scale takes place. If the soil is tolerably well supplied with lime, the mono-calcium phosphate will become converted into di- or tri-calcium phosphate. When, however, the soil does not contain very much lime, but is rich in iron, much of the soluble phosphate will become ferric phosphate. The former course of events is very much preferable.

For the purpose of examining super-phosphate it is common to take a portion that is soluble in water for the estimation of phosphoric acid. In the United States of America it is also common to determine the amount that dissolves in ammonium citrate. The difference of the two standards is not, in modern products, a great one. The phosphate applied as super-phosphate will not penetrate any depth in an ordinary soil beyond about six or eight inches. Super-phosphate is of especial value as a quick-acting phosphatic manure, and can be used even as a top dressing. As many soils are deficient in phosphates, super-phosphate is often one of the fertilizers which produce the most striking and obvious results.

A particular type of fertilizer which has proved useful is called basic super-phosphate. This consists of a mixture of super-phosphate and lime. By these means the superphosphate is turned into phosphate insoluble in water, but very easily soluble in the very weakest of acids. (See Hughes, 
Bibliography.) It has the advantage over super-phosphate that it is not acid in character, and, therefore, does not encourage the development of "Finger and Toe" disease in turnips. Its extreme solubility in very feeble acids makes it practically as available to the plant as super-phosphate. It is also very dry and fine, and easily distributed. A somewhat similar material called precipitated bone phosphate is obtained as a by-product of the glue and gelatine manufacture. (See Bennett.) When bones are treated with cold dilute hydrochloric acid, the framework of the bone is left in gelatine and the calcium phosphate dissolved by the acid. The acid liquids, together with the washings, are then precipitated with just enough lime to recover all the phosphoric acid, giving a precipitate about half di-calcium phosphate and half tri-calcium phosphate. The two lastnamed fertilizers are favourites with those who grow turnips on a large scale.

Bone Black and Bone Ash.-In sugar refineries considerable quantities of bone black were used. After a time it is beyond the power of the users to regenerate the bone black for their purpose, and this is then sold as a fertilizer. Bone ash, made either by burning bones or by burning the refuse from the sugar refineries alluded to above, or obtained direct from South America, is used for fertilizing purposes. The difference between used-up bone black and bone ash is, from a fertilizer point of view, of no particular importance, since a few per cents. more or less of carbon will not influence the results. Bone ash is fairly readily available in the soil, and in this respect resembles basic slag. It is, of course, a purely phosphatic manure, and may contain anything up to 85 per cent. of tri-calcium phosphate. It is quite suitable for any of the purposes of precipitated phosphate or basic super-phosphate, but cannot be used as a top dressing like super-phosphate. Bone ash, when finely ground, is almost entirely soluble in weak citric acid.

Fertilizers containing both Nitrogen and Phosphorus. -The different requirements of crops and soils preclude the possibility of any fixed ratio between nitrogen and 
phosphorus in fertilizers, but for most arable purposes both will be required. Probably fertilizers containing two ingredients are often sources of loss, since one of the ingredients is likely to be in excess. This loss can only be avoided if very careful study is made of the conditions, and the ratio of nitrogen to phosphorus adjusted to suit the special requirements.

Bones.-Bones became very popular as soon as the early ideas of phosphatic manure became at all widespread. The bones of animals invariably contain some grease. The amount of grease varies with the bone, but on the general average a raw bone or rag bone contains about I 2 per cent. water, 28 per cent. nitrogenous organic matter, Io per cent. fat, 44 per cent. tri-calcium phosphate, and 5 per cent.calcium carbonate. There are also traces of magnesia and fluorine. Large bones of such a composition are very slow in decomposing in the soil, and may be regarded as having no practical value. If they are finely ground their value is greatly increased, but the fat content acts as a preservative and diminishes the value. Fortunately, the fat can be made a better use of. Under the best systems the rag bones are extracted with petroleum spirit, and the grease obtained is a valuable product. The extraction of the fat renders the bones porous, easy to grind, and available after application to the soil. The high-class bone meal obtained in this way will often have over 5 per cent. of nitrogen, and about 40 per cent. to 45 per cent. of tri-calcium phosphate. In some works, however, the fat is removed by a process of steaming and boiling, which removes a good deal of gelatine as well as fat. The remaining bones from this process are very porous, grind very easily, and are far more readily available to plants. According to the degree of treatment the bones have received, the composition will vary from 3 per cent. nitrogen and 50 per cent. tri-calcium phosphate to I per cent. nitrogen and 60 per cent. tri-calcium phosphate. The term "bone meal" is commonly understood to mean materials containing 4 or 5 per cent. nitrogen, which have been obtained by some petroleum extraction; whilst the term "bone flour" is commonly understood to mean the materials 
containing from I to 3 per cent. of nitrogen, obtained by some boiling or steaming process. When finely divided, these bone fertilizers are readily available in the soil, and may be considered as more or less equivalent to basic slag, but of course the nitrogen is in addition. The small amount of calcium carbonate present in the bones is also useful to the soil. Like all other manures containing organic matter bones will provide some food for bacteria or other forms of soil life.

Bones are also treated with sulphuric acid in the same way as mineral phosphates are treated for the production of super-phosphates. The product is generally known as dissolved bones or vitriolated bones. For the manufacture of this article rather stronger acid is necessary, and it is not practicable to get the whole of the phosphate into solution. The general run of dissolved bones contain about 3 per cent. of nitrogen, I 5 per cent. of phosphates which have been rendered soluble, and I 5 per cent. of phosphates which have not been acted on by the acid at all. By these means the nitrogenous matter is dissolved as well as the phosphatic material, so that the resulting dissolved bones must be looked upon as a mixture of four fertilizing ingredients, namely, soluble phosphates, insoluble phosphates, soluble nitrogen, and insoluble nitrogen. The advantage of having two degrees of solubility is very marked : the insoluble phosphates will, on application to the soil, remain on the surface, and the soluble will penetrate to a depth of a few inches. Insoluble nitrogen may be left on the surface, but the soluble nitrogen in this case will penetrate probably to a foot in the soil, since those portions which are in the form of aminoacids will not be at all readily fixed by the soil, but will penetrate to a greater depth than ammonia salts could (see pp. 7 and i3). As such materials will be very mixed the nitrogen will be distributed over a considerable range and depth of soil, and will therefore suit a variety of crops in very varied stages of growth.

A very frequent type of bone manure is composed of super-phosphate, bone flour, and sulphate of ammonia. Here again there is the advantage of two kinds of phosphorus 
and two kinds of nitrogen. For the early growth of practically all crops a rich surface is necessary. When, however, the plants have grown it is desirable that the fertilizing ingredients should be deeper in the soil, to prevent an excessive development of surface root, with the subsequent susceptibility to drought.

Guano.-This old-established and favourite type of manure is produced on rocky situations with little rainfall, from the accumulations left by sea-birds during the nesting season. Where the rainfall is very scanty the amount of nitrogen in the guano may be as high as II per cent. Where the rainfall is considerable the nitrogen may be removed by washing till it falls to $I$ per cent. In guano produced under dry conditions the phosphoric acid is partially soluble in water; but in that produced in wet situations the constituents are all insoluble. A small quantity of potash is often present, say I per cent. The varieties of guano may be divided into those whose value is chiefly due to the nitrogen and those whose value is chiefly due to the phosphorus. The phosphatic kinds will barely differ in their properties from bone flour. Those of the nitrogenous kind will be of a more complex character, containing both nitrogen and phosphorus in various degrees of solubility. Some of the less valuable guanos are treated with sulphuric acid to render them more soluble.

A great variety of artificial mixtures are put upon the market to supply both nitrogen and phosphorus. As a rule the basis of these is super-phosphate, to which has been added some bone, any of the nitrogenous organic manures described above, and not infrequently a miscellaneous collection of materials of lower value. Some materials, in themselves almost worthless, can be so treated as to bring them into use for this group. For example, leather in itself is of little manurial value, but it can be treated with sulphuric acid and thereby dissolved. The acid is not lost in the process, but is still capable of dissolving mineral phosplates. Such a mixture will contain the leather in a digested form, as well as soluble and insoluble phosphate. 
Such mixtures as are here being described are very rarely suitable for top dressing. They are best, therefore, applied in the drill either with or without farmyard manure. Containing a variety of ingredients, they are in many respects safer, since even if the user possesses the knowledge to apply crude fertilizers, he still is at the mercy of the weather, and it is not possible to predict exactly which of the crude fertilizers would be the best to apply. A mixture which contains a variety is much more likely to apply at least something that is necessary (see Introduction).

\section{REFERENCES TO SECTION II}

Collins and Hall, "The Inter-relationships between the Constituents of Basic Slag," Journ. Soc. Chem. Ind., I9I 5, p. 526.

Robertson, "The Influence of Fluorspar on the Solubility of Basic Slag in Citric Acid," Journ. Soc. Chem. Ind., I9I6, p. 216.

Bernard Dyer, "Available Mineral Plant Food," Journ. Chem. Soc., I894, p. II 5 .

Hughes, Journ. Soc. Chem. Ind., I9or, p. 325.

Robertson, "Notes on the Nature of the Phosphates contained in Mineral Phosphates," Journ. Agric. Science, 8, p. I7.

Robertson, "Solubility of Mineral Phosphates in Citric Acid," Journ. Soc. Chem. Ind., I9I6, p. 217.

Bennett, "Animal Proteids."

Jones, "The Wagner Test as a Measure of the Availability of the Phosphate in Basic Slag," Journ. Board Agric., I9I4-15, p. 201.

Davis, "The Phosphate Depletion of Soils of Bihar," Agric. Journ. Ind., 1917, p. 181.

Jatindra Nath Sen, "The Influence of the Presence of Calcium Carbonate on the Determination of Available Phosphoric Acid in Soils by Dyer's Method," Agric. Journ. Ind., I9I 7, p. 258. 


\section{SECTION III.-THE POTASSIUM GROUP OF FERTILTZERS}

For some years past the German potash manures have completely eclipsed other sources of potash, and it is only since the war that non-German sources have once again come into prominence. There is little doubt that the German potash manures originated in the same way as most salt deposits, that is to say, sea water has been naturally evaporated, producing sodium chloride, then complex salts of magnesium and potassium sulphates or chlorides, together with a deposit of calcium sulphates. The material put upon the market as kainit has, for a long time, had little connection with the mineral properly so named, but has simply been a blend graded to I $2 \frac{1}{2}$ per cent. pure potash $\left(\mathrm{K}_{2} \mathrm{O}\right)$, the remainder of the material being chiefly sodium chloride, with some magnesium sulphate. The composition of the German kainit manure has been very constant, the average over many years past having been $12.50 \pm 0.38$ per cent. $\mathrm{K}_{2} \mathrm{O}$ for any single sample. Other important potash manures of German origin have been the sulphate and the muriate (chloride). The better qualities of these have been about 90 per cent. purity, but lower grades have also been on the market. They have always been sold under guarantee.

A very old type of potash manure is wood ash. The ashes of full-grown timber do not contain much potash, but the ashes of small twigs are fairly rich. The table on p. 38 will roughly show the amount of potash in many types of wood ashes.

The ashes of coal contain hardly any potash, but certain particular wind-blown coal ashes in industrial concerns contain appreciable quantities of potash. The dust deposited 
TABLE 4.-WOOD Ashes.

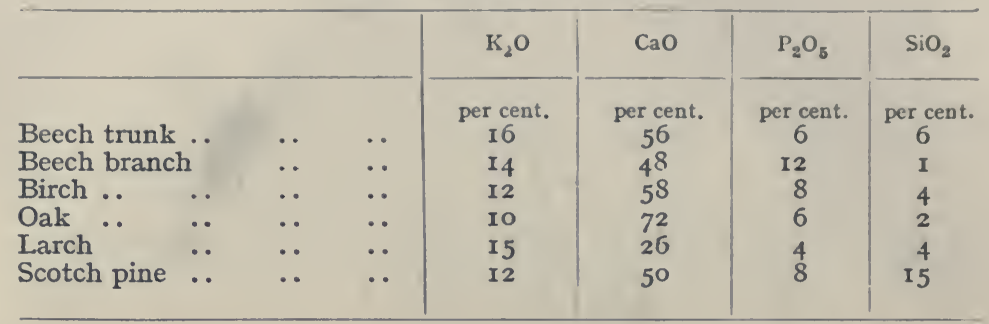

If in the Table 4 the figures represent pounds, it would take $4 \frac{1}{2}$ tons of beechwood or $8 \frac{1}{2}$ tons Scotch pine to be burnt for their production.

in flues of blast-furnaces and boilers often contains a concentration of certain ingredients which may raise the potash in the dust to 5 or Io per cent. The vast majority of these materials are, however, very disappointing, and rarely repay transport, although by evaporation of an aqueous extract a concentrate may be obtained. A useful waste product is obtained in the case hardening of steel, during which small parts of machinery are heated, then plunged into mixtures some of which contain potassium ferrocyanide. Although this material when used for case hardening lasts a long time, when worn out it is still rich in potassium, and may even contain 20 per cent. potash. The cyanides present would be prejudicial to plant life if applied after the plant had started growth, and would also tend to check germination. Similarly, even wood ashes, being strongly alkaline, should be allowed some time to work into the soil before the seeds are sown.

The reactions of potassium sulphate with the soil are very similar to those of ammonium sulphate. The potash combines with clay and humus, and the sulphuric acid combines with lime, and then washes out of the soil. Potassium chloride reacts similarly, the chlorine taking lime and washing out of the soil. When crude materials, like kainit, are applied to the soil the sodium chloride washes out, leaving the potash and most of the magnesia behind. These manures tend to exhaust the soil of lime. Wood ashes, however, do not take away lime out of the soil, but tend to make it alkaline and 
deflocculated, and, therefore, to interfere with bacteria or plant life. Such refuse materials as contain cyanides will require a fairly lengthy period to enable the poisonous cyanogen compounds to be rendered harmless and converted into useful nitrates. It may be taken as a general rule that potash manures should be applied early. Potash is not fixed in the soil with quite the same completeness as phosphate, but in a parallel calculation to that given in the section dealing with phosphatic manures it has been found at Rothamsted that something like about three-quarters of the potash can be accounted for, the remainder having presumably buen lost in the drainage during fifty odd years. The need for potash manures is not as great as for phosphates or nitrogen. Clay soils contain a sufficient amount of potash for most crops. It is only on the light and sandy soils that potash manure is absolutely essential. The really most important member of the group of potassium fertilizers is, however, farmyard manure. The recent effort to utilize blast furnace dust promises a valuable addition to home potash production.

\section{REFERENCES TO SECTION III}

Cresswell, "Possible Sources of Potash," Journ. Soc. Chem. Ind., April, :915, p. 387 ,

Russell, "How can Crops be Grown without Potash ?" Journ. Board of Agric., r915-r6, p. 393.

Voelcker, "Absorption of Potash by Soils of known Composition," Journ. Roy. Agric. Soc., 25, II.

Schreiner, "The Absorption of Potassium by Soils," Joum. Phys. Chem., I906, p. 36r. p. 526 .

Cranficld, "A New Source of Potash," Journ. Board of Agric., I9 17-18, 


\section{SECTION IV.-MIXED FERTILIZERS}

As a general rule both crops and soils will demand a mixture of the crude fertilizers, and there are many occasions on which it is convenient to be able to purchase ready-made mixtures of these crude materials. The chief difficulty that occurs in the application of crude fertilizers is in their even distribution over the land. It is, therefore, advantageous to obtain a material which is not too concentrated in any one ingredient. Hence there is a distinct advantage in obtaining several materials ready mixed. As, however, the requirements of soils and crops are very varied, and climatic conditions will modify the needs of any particular crop or soil, it becomes practically impossible to design a mixture for any large group of districts, soils, or crops. Certain general principles are quite well established, (I) nitrogen for cereals, phosphorus for roots, potassium for pulses, and (2) phosphorus for heavy soils, and potassium for light soils. But it is quite impossible to adhere rigorously to any such system, because in practice a succession of crops are grown, and what is left over from one crop is used up by the next. Nevertheless, there is a distinct demand for specific mixtures. A very popular mixture is potassic super-phosphate blended so as to contain about 20 per cent. soluble phosphate, and about 3 per cent. potash. Such a mixture can be made in a dry form, handier for distribution than either of its ingredients alone. Mixtures of super-phosphate, sulphate of ammonia, and potash salts are often made and sold under specific names, such as "Corn Manure," "Grass Manure," or "Turnip Manure." Too much attention should not be given to the name. Estimates should only be based on the guaranteed analysis. Provided 
the guaranteed analysis and the price correspond, and granted that the material is in a good, convenient condition for sowing, and that the mixture really represents what the crop on that particular soil and under that particular climate wants, then this mixture may be used with satisfaction. For the purpose of checking the prices of these materials, a unit of 22.4 pounds is commonly adopted. For Great Britain these unit prices are published in the Journal of the Board of Agriculture, which will give the values from time to time. For example, in the number for April, I9I7, one may see that in London the unit price of nitrogen in the form of sulphate of ammonia was $15 s$. $4 \frac{1}{2} d$., but that nitrogen in other forms was more expensive, and that at all the other places named in the table the same was true. Thus with any mixture in which nitrogen is probably derived from sulphate of ammonia it would be not unreasonable to take this figure. The value of a unit of soluble phosphate in super-phosphate varies according to place from $3 s$. $I \frac{1}{2} d$., to $4 s$. $8 \frac{1}{2} d$., and for rough purposes one may call it $4 s$. At the time potash is not quoted, but before the war potash was valued at $3 s$. or 4s. a unit. A calculation can be made as follows:-

TABLE 5.-MANURE.

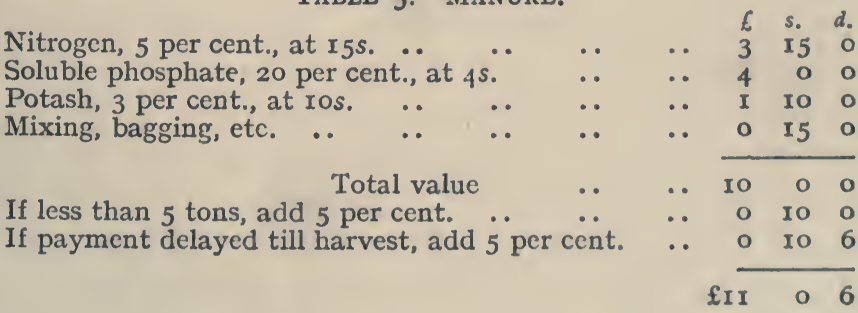

Prices will vary from time to time, but are published monthly in the Journal of the Board of Agriculture.

It is not difficult to make one's own estimate of unit prices for one's own special conditions. Sulphate of ammonia contains so nearly 20 per cent. of nitrogen that the unit price of nitrogen in sulphate of ammonia is almost exactly the same in shillings as the price is in pounds per ton, that is, when sulphate of ammonia costs about $£ 16$ per ton the unit 
price of nitrogen is $I 6 s$. If super-phosphate, with 30 per cent. of soluble phosphate, cost about $£ 6$ per ton, each one per cent. will cost $4 s$. It will be noted, in comparing the tables of the Journal of the Board of Agriculture, that sometimes special forms are very expensive; for example, in dissolved bones soluble phosphate is much more expensive than in super-phosphate. The nitrogen in dissolved bones is assessed at a high rate, as it is also in the case of nitrate of soda, but all these conditions are quite temporary, and a few months later on the relative prices may be different.

In practice, the farmer should endeavour to discover for himself, by experiments, what particular mixture suits his soil and system of farming.

Farmyard Manure. -This very ancient and wellknown commodity owes its value partly to its chemical, partly to its physical, and partly to its biological effects. The elementary constituents are carbon, hydrogen, oxygen, and nitrogen, which constitute the non-metallic part; potassium, phosphorus, calcium, which constitute the metallic part, both parts being of value; with some small amounts of aluminium, iron, and silicon, which may be considered as having no value. These materials are combined together as humus, organic fibre, and salts. Water is present to the extent of from 60 per cent. to 80 per cent. Farmyard manure is by no means a dead thing. It is full of bacterial life, which has a strong influence on its value. Considering, first of all, the forms in which these elements of value occur, we find that the nitrogen is very rarely indeed in the oxidized condition of a nitrate. Very old heaps of farmyard manure, say two years old, certainly do contain small quantities of nitrate, but this age is not usual in farm practice. An important fraction of the nitrogen is present in the form of ammonia, which chiefly occurs as the result of the decomposition of urea $\mathrm{CO}\left(\mathrm{NH}_{2}\right)_{2}$. Urea is fermented by a special micro-coccus, so that in a day or so the urea has become completely converted into ammonium carbonate. The ultimate result of this change is represented by the equation $\mathrm{CO}\left(\mathrm{NH}_{2}\right)_{2}+2 \mathrm{H}_{2} \mathrm{O}=\left(\mathrm{NH}_{4}\right)_{2} \mathrm{CO}_{3}$. The ammonia so produced 
will very likely react with some of the sulphates present, so that in the manure heap the ammonia will be partly as ammonium sulphate. In addition to this, as the organic matter is decomposed by bacterial action, a portion of it will form those vague compounds which we call humic acid, which will enter into combination with the ammonia and produce the soluble, dark-brown coloured substance, ammonium humate. Some nitrogen is also present in the amide form. Urea itself is an amide, but is not the only one present. Many other amides are produced by the action of bacteria upon proteins. Amino-acids and peptones are also present. A fair proportion of the soluble nitrogen which exists in the manure heap results from the bacterial digestion of the proteins. Many of the bacteria in the manure heap belong to the class that liquefy gelatine. The liquefaction of gelatine is only a special, easily observed case of the peptonization of proteins, and a part of the proteins which have not been digested by the beasts goes into the peptone form in the manure heap. Of the albuminoids in the dung, some are soluble, but most are not merely insoluble in water, but very resistant to all chemical change ; indeed part of the proteins that are passed by the beasts is the residuum of dead bacteria, which needs protracted decomposition.

The potassium in the manure heap will occur as potassium sulphate and potassium humate. Most of the potassium is soluble, and therefore very easily lost, unless care be taken for its preservation.

The phosphorus in the manure heap is very largely in the form of phosphates, but some part is organic. Although the manure heap is alkaline, and contains lime and ferric hydrate which would normally precipitate all the phosphates, yet in the presence of so much soluble organic matter, iron and calcium are not able to precipitate phosphoric acid in alkaline solution, so that, as a rule, at least one-half of the phosphorus is soluble.

The calcium present is not in sufficient quantities to appreciably affect the total value of the manure, but it has some action upon bacterial life. It will occur mostly in 
combination with humic acid, with which the calcium forms an insoluble compound, but some soluble substance, like calcium sulphate, will often be found in the manure heap.

The organic materials occur chiefly either as fibres or as gummy matter. The fibrous material is very important in enabling the manure heap to retain its liquid constituents, and in maintaining the open structure necessary for admission of air in limited amounts. The gummy material provides the humic acid and other colloids, which will fix or absorb the substances of manurial value. The water present plays a large part in the decomposition of the manure heap and is chiefly absorbed by the litter. The bacteria present are mostly such common forms as coli communis or subtilis, the former derived from the beasts and the latter from the fodder.

The study of the proximate constituents is quite as important as that of the ultimate constituents. These consist of three parts, the dung, the urine, and the litter. The dung owes its chief value to nitrogen and phosphorus. In old animals it is richer than in young animals, because the young animals utilize food better. In the case of the grainfed horse it is rich and decomposes rapidly; but in the case of the grass-fed horse it is poorer, and slower in action. Sheep produce the richest and the cow produces the poorest. A fat bullock will produce better dung than a cow, and the manure will decompose much quicker.

The urine which decomposes very rapidly owes its chief value to nitrogen and potassium. With root-fed beasts it is weak, and with grain-fed beasts it is concentrated. Much of the nitrogen occurs as urea, and ferments to ammonium carbonate within two or three days. If the food is very coarse-that is, contains much straw or inferior hay-as much as one-third of the nitrogen appears in the form of hippuric acid (benzamido acetic acid, $\mathrm{C}_{6} \mathrm{H}_{5} \cdot \mathrm{CO} \cdot \mathrm{NH} \cdot \mathrm{CH}_{2} \cdot \mathrm{CO} . \mathrm{OH}$ ). It will be noticed at once that nitrogen for nitrogen, hippuric acid contains very much more carbon than urea, $\mathrm{CO}\left(\mathrm{NH}_{2}\right)_{2}$, and its excretion involves loss of food and loss of energy. When foods contain a big proportion of pentosans the amount 
of hippuric acid secreted is much greater. Of the other constituents of the urine the potassium occurs as sulphate and chloride, whilst sodium occurs as sodium chloride.

The litter is a very important part of the manure heap. Unless there is a generous supply of litter the beasts will be uncomfortable and the valuable portion of the manure will be lost by drainage. Most of the potassium and half of the nitrogen occur in soluble form, which are only retained by the absorptive capacity of the litter. The litter itself may contain some nitrogen, phosphorus, and potassium, but its chief value depends upon the water-absorbing capacity. One part of leaves will absorb about two parts, by weight, of water; straw will hold three parts ; sawdust four parts; tan refuse five parts; rough peat six parts ; and picked peat-moss litter about ten parts. Some very exceptional peat-moss litter may even hold eleven or twelve times its weight of water without drainage. It is not practicable under ordinary conditions to get such good results as these, because the trampling of the beasts will compress the litter, and squeeze something out, but the relative values of the materials will be roughly as stated. In practice much will depend upon the relative cost of these different forms of litter, but where practicable the more absorptive kinds should be preferred, because it will save so much labour in handling bulky useless material. However a good deal of the value of the manure depends upon its physical effect in the soil, its provision of food for soil organisms, and its production of carbon dioxide in the soil. It is not possible to lay down any very strict rules on this subject. Straw will certainly provide better food for soil organisms than most of the other ingredients named. Sawdust appears to encourage harmful organisms if large quantities of manure are used, if it is badly distributed in the soil, and if the soil is wet and compact. Admission of air to the soil is also an important point in the value of farmyard manure, and for such a purpose peat-moss litter will serve much better than any other member of the series. It must also not be forgotten that the straw might be used partly for feeding, as it would then not be 
necessary to use so much straw for bedding. A very common and useful solution of these difficulties is to use both, to put peat moss litter at the bottom and clean straw at the top. It makes a very comfortable bed for the beasts, and the liquor is well absorbed by the peat moss underneath. The relative absorptive value of most of these materials is increased by fine chopping, and unpromising materials may be much improved by being passed through a chaff cutter. The relative absorptive power of different litters can be so easily determined that it would be wise for users to test them themselves. All that is necessary is some sort of scales and measuring vessel. A very convenient method is to weigh 5 grammes of the material, add Ioo cubic centimetres of water, and allow to soak for a few hours. The remaining mixture is then poured on to a funnel, which has placed in it a small filter disc or even a common marble. The portion of liquor drained through is measured in the cylinder, and the difference from what was originally taken gives the portion absorbed. With peat-moss litter it will be found that 5 grammes will absorb about 50 cubic centimetres, or an absorptive capacity of ro per unit.

The Manufacture of Farmyard Manure.-As regards the quantities produced, a cow will give about 45 pounds of dung every day, containing about 8 pounds of dry matter and 37 pounds of water. In the average of all animals the organic matter in the dung represents 43 per cent. of the organic matter eaten, and the nitrogen yielded is 20 to 40 per cent. of that eaten. This wide range of nitrogen is due to the great variation in the proportions of nitrogenous matter in the food. The phosphorus in the dung equals 95 per cent. of that eaten, and the potassium about I 6 per cent. of that eaten.

Urine.-The cow gives about $5 a$ pounds a day, with 4 pounds of dry matter, but the amount is very subject to variation, according to the type of feeding. The organic matter equals about 3 per cent. of that eaten, the nitrogen from 60 to 80 per cent. of that eaten, the phosphorus about 3 per cent. of that eaten, and the potassium from 80 to 85 per cent. 
of that eaten. A striking point is the great difference between the mode of excretion of potassium and phosphorus - the potassium is almost entirely in the liquid portion, and the phosphorus almost entirely in the solid portion.

Taking the whole excreta togetler, the organic matter corresponds to 46 per cent. of that eaten, the nitrogen from 70 to 95 per cent. of that eaten, and the potassium and phosphorus from 95 to 98 per cent. of that eaten. It will be noticed, therefore, that very little phosphorus and potassium are actually removed and sold off the farm in the form of meat. The loss of nitrogen by sale from the farm is slightly greater, but under conditions of feeding livestock very little of the manurial ingredients are sent away, and the stock in hand of fertilizing elements is always very large. The possible loss by drainage of the nitrogen can be made up on the farm itself by other methods, as shown in Part II., but the loss of potassium salts by drainage constitutes a serious diminution in fertility of the soil. It can only be replaced by purchases of potassium compounds. In India, and other countries where cattle feeding is not carried out systematically, but where bullocks are used for draft purposes and not fattened for beef, little attention is paid to conserving the manures from the animals. Very often the cattle dung is not used as manure at all, but is used as fuel, mixed with straw, or as a material for plastering walls, etc. Where it is used as a manure it contains no litter or urine.

TABle 6.-ManuRE in INdia.

\begin{tabular}{|c|c|c|c|c|c|c|}
\hline * & & & & $\begin{array}{l}\text { Cattle dung. } \\
\text { Grass fed. }\end{array}$ & $\begin{array}{l}\text { Cattle dung. } \\
\text { Well fed. }\end{array}$ & Cattle urine. \\
\hline Water $\quad$. & .. & . & .. & $75^{\circ} \mathrm{O}$ & $73^{\circ} 5$ & $93^{\circ} \mathrm{O}$ \\
\hline Organic matter & . & - & . & 14.5 & II.O & 3.5 \\
\hline Nitrogen .. & .. & - & . & 0.27 & 0.35 & $0 \cdot 56$ \\
\hline Phosphoric acid & .. & .. & .. & 0.18 & 0.14 & 0.02 \\
\hline Potash $\quad$.. & .. & . & . & $0 \cdot 30$ & 0.18 & $\mathbf{I} \cdot 13$ \\
\hline Lime & .. & -. & . & $0 \div 28$ & 0.25 & 0.12 \\
\hline
\end{tabular}

Passage from Food to Dung.- The history of the nitrogen that is consumed by the live-stock on the farm is shown in the following table:- 
TABLE 7.-Nitrogen History of Feeding.

\begin{tabular}{|c|c|c|c|c|c|c|}
\hline & & & \multirow{2}{*}{$\begin{array}{c}\text { As carcase } \\
\text { or milk } \\
\% \text {. }\end{array}$} & \multicolumn{3}{|c|}{ Excreta \%. } \\
\hline & & & & Solid. & Liquid. & Total. \\
\hline Horse at rest & .. & $\cdots$ & - & 43 & 57 & 100 \\
\hline Horse at work & .. & .. & - & 29 & 71 & 100 \\
\hline Fattening ox & .. & .. & 4 & 23 & 73 & 96 \\
\hline Fattening pig & .. & .. & I 5 & $2 \mathrm{I}$ & 64 & 85 \\
\hline Fattening sheep & .. & $\cdots$ & 4 & I7 & 79 & 96 \\
\hline Milking cows & .. & $\because$ & 25 & I 8 & 57 & 75 \\
\hline Calf on milk & $\cdots$ & $\cdots$ & 69 & 5 & 26 & $3 I$ \\
\hline Average of all & $\cdots$ & $\cdots$ & I7 & 22 & $6 I$ & 83 \\
\hline $\begin{array}{l}\text { Average of work } \\
\text { ox and sheep }\end{array}$ & ing & $\begin{array}{c}\text { rse, } \\
\text { - }\end{array}$ & 3 & 23 & 74 & 97 \\
\hline
\end{tabular}

From which it will be seen that the effect of working a horse is to increase the proportion of nitrogen that is excreted in the liquid. The cow gives a higher proportion of nitrogen as saleable products, and, in consequence, leaves less for the manure heap. A calf fed on milk uses up most of the nitrogen for its growth, and leaves but a small fraction for manure. The average stock on a farm will vary according to the system of management, but in no case will the proportion of nitrogen sold be anything but small. The bulk of the nitrogen that is eaten in the food goes back into the manure, mostly in the soluble form and liable to loss by drainage. The farm is, therefore, compelled to carry a very big working capital in the form of nitrogen, from which the annual return is comparatively small.

A parallel table can be worked out for the potassium history.

Tabie 8.-Potassium History of Feeding.

\begin{tabular}{|c|c|c|c|c|c|c|}
\hline & & & \multirow{2}{*}{$\begin{array}{c}\text { As carcase } \\
\text { or milk } \\
\% .\end{array}$} & \multicolumn{3}{|c|}{ Excreta \%. } \\
\hline & & & & Solid. & Liquid. & Total. \\
\hline Horse $\quad \ldots$ & .. & .. & - & $\mathbf{I}_{4}$ & 86 & 100 \\
\hline Fattening ox & .. & .. & I & 16 & 83 & 99 \\
\hline Fattening sheep & .. & .. & I & 6 & 93 & y9 \\
\hline Fattening pig & .. & .. & 2 & $I_{4}$ & 84 & 98 \\
\hline Milking cow & .. & $\ldots$ & Io & 16 & 74 & 90 \\
\hline
\end{tabular}


It will be seen in this table that, excepting in the one case of cows giving milk, the proportion returned as saleable is very small indeed. Very nearly the whole of the potassium in the food is returned to the manure heap in a liquid form, easily lost by drainage. The conservation of this potassium is a very important problem, since where there are clay fields the amount of potassium in the soil is naturally large, but where the soil is sandy the potassium is needed as a fertilizer.

The phosphorus history of the food eaten is given in Table 9, from which it will be seen that the major part of the phosphorus eaten is returned to the manure heap in the solid form, and is, therefore, not easily lost.

TABle 9.-Phosphorus History of Feeding.

\begin{tabular}{|c|c|c|c|c|c|c|c|}
\hline & & & & \multirow{2}{*}{$\begin{array}{c}\text { As carcase } \\
\text { or milk } \\
\% \text {. }\end{array}$} & \multicolumn{3}{|c|}{ Excreta \%. } \\
\hline & & & & & Solid. & Liquid. & Total. \\
\hline Horse & .. & . & $\ldots$ & - & 99 & I & 100 \\
\hline Ox & .. & . & .. & $I_{4}$ & 85 & I & 86 \\
\hline Pig & .. & .. & .. & I 6 & 63 & 16 & 8.1 \\
\hline Sheep & .. & . & .. & 14 & 83 & 3 & 86 \\
\hline Cow & -. & .. & $\cdots$ & 23 & 76 & $\mathbf{I}$ & 77 \\
\hline
\end{tabular}

Considering the very big increase in crop often produced by phosphatic manures, and considering the very small risk of loss, every possible step should be taken to increase the use of phosphatic fertilizers. Nothing like the amount that ought to be used is applied in common practice.

Great variation will occur in the composition of the manure, according to the particular system employed. Table ro shows the comparison between feeding on very wet food and on very dry food.

These conditions represent extremes, but there is much room for variation between these limits. When very watery food is fed, the amount of liquid manure is much increased, and carries with it a bigger quantity of dry material. In both the foods actually selected the amount of potassium is high, and, therefore, there is ample to spare for all purposes.

D. 
TABLE IO.-POUNDS TO OR FROM ONE COW IN ONE DAY.

\begin{tabular}{|c|c|c|c|c|c|c|c|c|}
\hline \multirow{2}{*}{ Total. } & \multicolumn{2}{|c|}{ Food. } & \multicolumn{2}{|c|}{ Manure. } & \multicolumn{2}{|c|}{ Food. } & \multicolumn{2}{|c|}{ Manure. } \\
\hline & $\begin{array}{c}\text { Solid. } \\
\text { (Mangels.) }\end{array}$ & Liquid. & Solid. & Liquid. & $\begin{array}{l}\text { Solid. } \\
\text { (Hay.) }\end{array}$ & \begin{tabular}{|l} 
Liquid. \\
(Water.)
\end{tabular} & Solid. & Liquid. \\
\hline Total & I 54 & - & 42 & 88 & 26 & 66 & 48 & $I_{4}$ \\
\hline Water & I 35 & - & 35 & 84 & 4 & 66 & 38 & 12 \\
\hline Dry matte & 19 & - & 7 & 4 & 22 & - & Io & 2 \\
\hline$N$ & $0 \cdot 30$ & - & 0.14 & O.II & 0.60 & - & 0.16 & 0.21 \\
\hline $\mathrm{P}_{2} \mathrm{O}_{5}$ & 0.14 & - & 0.10 & 0.01 & 0.15 & - & 0.08 & - \\
\hline $\mathrm{K}_{2} \mathrm{O}$ & 0.72 & - & 0.06 & 0.53 & 0.49 & - & O.II & 0.24 \\
\hline
\end{tabular}

Of the nitrogen, much better utilization is made in the more digestible and watery mangels than in the dry and less digestible hay. Since there is six times as much liquid in the excreta from mangels there would have to be used six times as much litter to obtain the same degree of conservation.

Storage of Farmyard Manure.-The storage of the manure heap is a matter of considerable practical importance. Soon after production fermentation begins. The first fermentation results in converting urea into ammonium carbonate. During this process some ammonia may be lost by fermentation and evaporation. A good supply of litter acts as an absorbant for ammonia, and the loss by volatilizing ammonia is probably very small under ordinary farm conditions, although in town stables, where there are many highly fed horses, the loss of ammonia may be so sufficiently marked as to be a nuișance. General decomposition produced by the actions of various bacteria soon starts in the manure heap. In broad outline, the anærobic bacteria attack the fibre and proteins, which they hydrolyze with the production of gummy or colloidal substances, peptones, and amino-acids. The aerobes have little chance of working in a fresh manure heap ; they are mostly confined to the surface, where they are able to carry on their oxidizing powers. The rate of action will depend upon the temperature, much liquid excludes air, lowers the temperature, and therefore the rate of decomposition. Much carbohydrate 
increases the speed of oxidation, raises the temperature, increases the general rate of decomposition, and sometimes assists in nitrogen fixation. All the fertilizing elements, that is, nitrogen, phosphorus, and potassium, increase the rate of decomposition, because they facilitate the multiplication of the bacteria. As the bacterial food is used up the rate of decomposition slackens.

Decomposition in the manure heap may proceed in undesirable directions. When nitrogen is made to change into compounds unsuited to the growth of crops the word "denitrification" is commonly applied to this state of affairs. "Denitrification" is often applied in two different senses. Firstly the sense of the actual evolution of nitrogen ; this may occur chemically by the interaction of nitrous acid upon ammonia, or by bacterial evolution of nitrogen from proteins. The latter is probably only a special case of the former, since the action of nitrous acid upon amino-acids is directly comparable to its action upon ammonia, and such changes are probably brought about by bacterial agencies. Once nitrogen is given off from the manure heap as elementary nitrogen it becomes mixed with the nitrogen of the atmosphere and may be regarded from a practical point of view as finally lost. The above is the reversal of the process of nitrogen fixation. The other meaning of "denitrification" is the reversal of the process of nitrification. In the process of nitrification the protein is broken down to simpler organic nitrogen bodies, then to ammonia, then to nitrites, and lastly to nitrates. When this process is reversed the proportion of nitrates diminishes. The reversion of nitrogen can be imitated in the laboratory by heating sugar, a nitrate, and potash in a tube, when organic nitrogen compounds are formed. In the manure heap these changes are chiefly controlled by the bacteria. Attempts to prevent the loss of ammonia from the manure heap by the addition of substances of an acid nature have done little good, although for town stables a sprinkling of gypsum is useful for sanitary purposes.

The main object of storage should be to promote 
fermentation, and to prevent loss by drainage. 'I'he loss by drainage may be very pronounced, even under carefully controlled conditions. In a series of experiments conducted at Cockle Park I found the results which are condensed in Table II. The sampling of farmyard manure presents great difficulties, hence the error of experiment is very large, but in the last column of the table I have expressed the average, with the probable error of the series.

Table ir.-Storage of Farmyard Manure in Cement Pits,
Cockle Park.

Losses and Gains during Six Monthi' Strorage.

\begin{tabular}{|c|c|c|c|c|c|}
\hline , & x 899. & I900. & $190 x$. & 1902. & Mean. \\
\hline Oroanic matter & Per cent. & Per cent. & Per cent. & Per cent. & Per cent. \\
\hline $\begin{array}{l}\text { Organic matter } \\
\text { Mineral matter }\end{array}$ & $\begin{array}{l}-22 \\
-\quad 1\end{array}$ & $\begin{array}{l}-20 \\
+22\end{array}$ & $\begin{array}{l}-13 \\
-2\end{array}$ & $\begin{array}{l}\overline{1} \\
+5\end{array}$ & $\begin{array}{l}-14 \pm 3 \\
+6 \pm 4\end{array}$ \\
\hline Total nitrogen & -23 & -29 & -9 & +2 & $-15 \pm 6$ \\
\hline Total phosphoric acid & +16 & -25 & +39 & -12 & $+5 \pm \mathrm{II}$ \\
\hline Total potash .. & -12 & -30 & -34 & $-I 6$ & $-23 \pm 5$ \\
\hline
\end{tabular}

It will be seen that when manure is kept in the circumstances stated, the organic matter and total nitrogen that are lost amount to about is per cent., within a reasonable margin of error, that the loss of potash is even greater, but that the phosphoric acid gives no evidence of any loss. The potash could, under those circumstances, only have been lost by drainage; the nitrogen might have been lost either by drainage or as elementary nitrogen. About a half of the nitrogen would have been insoluble in water, and of the remaining half some at least would have been in the colloidal form, difficult of diffusion. One would, therefore, expect that if 23 per cent. of potash can pass away by drainage, the nitrogen loss by drainage should be less than half that figure. I,ictle error in these experiments would occur from nitrogen fixation, since the dung was made by bullocks. There may be, therefore, a slight loss of nitrogen into the atmosphere, but it is very clear that the most pressing reform is to prevent loss by drainage. In places where there is a pit, to collect the drainage, the drainage is pumped up 
by a pump of the disc and chain type, and allowed to flow over the dry upper surface of the manure heap. By persistently pumping the drainage, it evaporates and becomes concentrated, and the proportion of liquor in the pit becomes diminished. Where the manure is stored on the field the most practicable method is to remove the surface of the ground, to break up the subsoil, to put the manure on top, to use the earth that has been dug out as a cover for the manure heap, and, when ready, to spread all the manure and all the broken subsoil on the field. By such means the loss by drainage can be reduced to a small figure. The general analysis of farmyard manure, kept under reasonable but not ideal conditions, is shown in Table 12 , which gives the probable composition of any sample taken at random, calculated from several analyses.

TABLE 12.-FARMYARD MANURE.

\begin{tabular}{|c|c|c|c|}
\hline & Probable sample. \\
\hline Moisture $\quad$.. & $\ldots$ & . & $75^{\circ} 3$ to $80^{\circ} 9$ \\
\hline Organic matter & .. & .. & $14^{\circ}$ to 18.8 \\
\hline Mineral matter & $\because$ & . & 0.43 to 5.9 \\
\hline Nitrogen non-albu & oid & .. & 0.15 to 0.27 \\
\hline Nitrogen total .. & .. & . & 0.54 to $0^{\circ} 72$ \\
\hline Potash $\quad \ldots \quad \ldots$ & . & . & 0.52 to 0.68 \\
\hline Phosphoric acid & & .. & 0.26 to 0.34 \\
\hline
\end{tabular}

In attempting to assess the money value of any such manure by the same standard as is adopted for chemical fertilizers one will see that the phosphorus is of little consequence, and in any normal circumstance the price would chiefly depend upon the nitrogen; but from a practical point of view the value of the manure will depend rather upon its physical properties in the soil, upon its percentage of potash, and upon its encouragement of the life of soil organisms.

It will be quite impracticable to have every fertilizer employed on the farm a quick-acting one. Some of the ingredients of any fertilizer must be of slow action to provide for the future. Farmyard manure should, therefore, be considered not in opposition to chemical fertilizers, but in 
partnership with them. The chemical fertilizers will supply the quick-acting and stimulating part, and the farmyard manure will supply the more lasting and soil-improving part. With the present lack of potash manuring, farmyard manure forms the chief source of that element in farming.

The Utilization of Sewage. - The primitive system of every man to his own land soon breaks down with large populations. Simple closets are very unsatisfactory, since flies communicate disease, and even smells are lowering to health. The earth closet is a great improvement if enough dry earth can be obtained. The resulting material, if removed to the garden, provides a useful fertilizer, but for towns the weight of the soil is an insuperable objection. Under the systems where the sewage is allowed to accumulate in cesspools great nuisance arises. A better system consists in removing all household refuse in carts at night. This mixture, known as " night soil," or "Scavenger," is carried to outlying farms, and either put direct upon the soil or put into trenches which have been previously dug. Farmers contract with municipalities to supply themselves and neighbours. Under these systems a rotation is adopted on the farm to suit periods of excessive manure, followed by periods of no manure at all. The details of such management on the farm will depend largely upon the local requirements, but the system has been found to work passably well when on a comparatively small scale. A more elaborate and industrialized system is that generally known by the French name of "Poudrette," where the night soil is taken to a factory and is there mixed with a suitable proportion of ashes and soil, allowed to ferment over one or two years, and then sold to the neighbouring cultivators. Such Poudrette contains about 20 per cent. of water, Io to I5 per cent. of organic matter, $\frac{1}{2}$ to I per cent. of nitrogen, and $\frac{1}{2}$ to $\mathrm{I}$ per cent. of phosphoric acid. Such a factory must be situated well away from the town. In very industrial districts the night soil collected may be taken to a factory and dried, and the grease extracted by petroleum spirit, the resulting material being supplied to the farmers in the 
neighbourhood as a dry powder. As the phosphoric acid content is low, mineral phosphates are sometimes admixed.

For countries with a plentiful seaboard the water-carriage system supplies a simple solution of the sanitary difficulties, since everything may be flushed into the sea, but such a system provides no solution of the agricultural side of the problem. The introduction of the sewage farm makes an attempt to get over this difficulty, and utilize the manure for food production. The conditions necessary for success are, however, exceptional. Where there happens to exist a suitable area of light soil, situated below the level of the town supplying the sewage, with facilities for providing a pipe with convenient gradients, the system may be a very great success. When only clay land is available the amount of land necessary becomes unreasonably large, and if too much sewage is put upon the land it is ruined for years. Considerable skill is therefore necessary in management. In some cases the sewage farms originally succeeded by an accident, because the condition of affairs caused an approximation to bacterial systems of purification. One of the great difficulties of a sewage farm lies in the fact that it has to take sewage according to the rate at which it is being produced in the town, and not to suit the requirements of the farm. If it were possible to entirely separate the rain-water of the streets from the pure sewage, much of this difficulty would be overcome, but it is very difficult to satisfactorily arrange a farm on the system of always having to take manure, whether it suits the crops or not. A not infrequent adjunct to a successful sewage farm is a pig-breeding establishment, as the pigs can eat up the large quantities of roots, etc., grown on a sewage farm, which fastidious people do not fancy. The hay crop is also a very important part of a sewage farm, since large crops of succulent, if coarse, hay can be obtained.

The Sludge Precipitation System. - To prevent the nuisance of crude sewage the idea arose of precipitating at least some of the material as a sediment or sludge, and a large variety of patent mixtures have been used for this purpose. 
Unfortunately the really valuable and important fertilizing ingredients remain in solution, whilst the sludge is of inferior composition. A very large tank space is necessary, and the materials obtained are of small value.

The Septic Tank Method.-Instead of trying to divert the normal course of events, a system of facilitating the natural decomposition of sewage has been introduced with very considerable success. In the decomposition of sewage there are roughly two stages. The first is due to the decomposition by anærobic bacteria, much in the same way as in the fermentation of farmyard manure, described above. During this process the insoluble matter goes into solution, even cellulose becoming very largely decomposed during this stage. Subsequently, the action of ærobic bacteria will oxidize the materials in solution, and convert them into inoffensive materials. In practice it has often been found unnecessary to adopt any elaborate plant to separate the two stages, since a preliminary depositing tank of small dimensions, to remove gravel and grits, followed by larger tanks, for the bacterial digestion suffices. Coke beds with sprinklers form a favourite modern oxidizing part of the system. The resulting liquors contain practically everything of value, and can either be run on to a farm, or be run into a river without harm. The sludge from the septic tanks is usually quite inoffensive, but its composition is very variable, and the dry matter may contain anything from $\frac{1}{2}$ to 2 per cent. of nitrogen. Not infrequently these sludges are mixed with some phosphatic fertilizer to render them more generally useful. Popular conceptions are apt to exaggerate the fertilizing importance of town sewage. The average produce of one man in one year is about II lbs. nitrogen, $2 \frac{1}{2} \mathrm{lbs}$. phosphoric acid, and $2 \frac{1}{2} 1 \mathrm{bs}$.potash. The sum of all the population is, no doubt, large, but the problem of this utilization presents very great difficulties, excepting on a small scale.

Miscellaneous Organic Mixed Fertilizers. - The droppings of poultry form a very well-known and much-prized manure for intensive purposes. Birds do not secrete waste 
nitrogen in the form of urea, but in the form of uric acid. The nitrogen is, therefore, not very soluble in water, although it decomposes in the soil fairly rapidly. The material varies considerably, but about I per cent. nitrogen, I per cent. potash, and 2 per cent. phosphoric acid will represent a rough average.

Seaweed is a useful fertilizer, available on sea-coast districts, where outlying rocks are covered with weed. During certain stormy seasons of the year a large amount of seaweed is thrown up on the coast. Where this becomes a nuisance local authorities are sometimes prepared to carry the seaweed some distance inland by traction engine, but ordinarily the farmer's own carts will have to tackle the business. Seaweed contains about 80 per cent. water, $\frac{1}{2}$ per cent. nitrogen, I per cent. potash, and $\frac{1}{4}$ per cent. phosphoric acid. One of the best uses for seaweed is admixture with the ordinary farmyard manure heap. If a heap be composed of alternate layers, six inches of seaweed and six inches of farmyard manure, the amount of manure at the farmer's disposal is doubled, and the general average composition not very seriously affected. Seaweed can also be used as a convenient mulch for protecting young plants against either drought or frost.

An important series of mixed organic manures are included in the group known as composts. These are conveniently made by mixing lime with all kinds of waste organic material. Blood, to which has been added about 2 per cent. quicklime, sets into a solid cake, which dries in the air, and breaks down to a powder. Lime mixed with hedge clippings, weeds, etc., will gradually work down into a convenient material for subsequent use. Attempts to ferment resistant articles, like bones, with either the drainings from the manure heap or fresh urine, are not very satisfactory, because nearly half of the nitrogen is lost during fermentation.

Vegetable or leaf mould is very valuable to gardeners, being more like rich soil than farmyard manure. In forestry work much importance is attached to beech mast, as it greatly improves the soil and facilitates subsequent growth, 
while carpets of pine needles form a useful mulch on the surface, but decay only very slowly.

Peat is also a material which can be used for fertilizing purposes on light sandy soils, or on heavy clays. It improves the water supply and aeration of the soil. Much attention has been directed to the attempt to ferment peat into something more immediately active. This very old idea has been revived recently, in the effort to give a carefully directed bacterial fermentation in place of a more haphazard decomposition. Very valuable reports on humogen have been given by Voelcker and Russell (see Bibliography). Whenever such materials as peat, having a very high capacity for absorbing water, are added in large quantities to a soil, they are perfectly certain to produce a beneficial result, but the expense and labour involved will often detract from their value.

Conclusion. - The very varied by-products of the industries which are capable of being used as fertilizers have been discussed above in moderate detail. Consultation with the various books referred to in the Bibliography will give many further details. Unintelligent use of fertilizers can easily do more harm than good, and a knowledge of the proper fertilizers requires not merely a knowledge of the fertilizers themselves, but also of the types of soil to which they are to be applied, the crops proposed to be grown, and the conditions under which the cultivation of these crops is undertaken.

\section{REFERENCES TO SECTION IV}

Collins, "The Valuation of Manures," The Journ. of the Land Agents Society, Sept., I908, p. 452.

Richards, "The Fixation of Nitrogen in Fæces," Journ. Agric. Science, 8, p. 299.

Russell and Golding, "Investigations on "Sickness" in Soil," Journ. Agric. Science, 5, 27.

Fowler and Clifford, "Notes on the Composition of Sundry Residual

Products from Sewage," Journ. Soc. Chem. Ind., I9I 4, p. 8r 5.

Rideal, "Sewage and the Bacterial Purification of Sewage," p. 330.

(The Sanitary Publishing Co.)

Dibdin, "The Purification of Sewage and Water," p. ro8. (The Sanitary Publishing Co.)

Rideal, "Disinfection and Disinfectants," p. 238. (Griffin.)

Weiss, "Directions for Preparing Manure from Peat," Journ. Board of Agric., 1916-17, p. 481.

Russell, " Report on Humogen," Journ. Board of Agric., I9I 7-r 8, p. I r. 
Bottomley, "Bacterised Peat; the Problem in Relation to Plant Nutrition," Journ. Soc. Chem. Ind., I916, p. 87x.

Hendrick, "The Value of Seaweeds as Raw Materials for Chemical Industry," Journ. Soc. Chem. Ind., I916, p. 565.

"The Cultivation of Seaweed in Ireland," Journ. Board of Agric., I9I $5-16$, p. 462.

Hendrick, "The Composition and Use of Certain Seaweeds," Journ. Board of Agric., 191 5-16, p. 1095.

Voelcker, Journ. Roy. Agric. Soc., I916, p. 246.

Aikman, "Farmyard Manure." (Blackwood.) 


\section{PART II.-THE SOIL}

\section{SECTION I.-SOILS AND THEIR PROPERTIES}

THE soil has two important and entirely distinct functions for assisting the growth of plants. (a) To supply a support and room for growth, and (b) to act as a storehouse for plant foods. The first of these functions is almost entirely of a physical character, the second is both physical and chemical, and very largely on the border-line between those two sciences.

Inspection of Soils. - Some general observations can be made on the spot by examining the soil in the field. Whilst the analysis of soils is a complicated business, which is not treated in this book, but left to the text-books specially devoted to such a very highly technical subject, yet the preparation of a soil sample which is required for analysis is a very important subject, and can very rarely be carried out by the actual analyst. For examining the suitability of a soil for specific crops and fertilizers, a very good plan is to dig a few holes in the field and inspect the soil. Once a hole has been dug in the ground it is easy to obtain a smooth vertically cut surface, which can be observed without disturbing the soil. It will generally be observed that at some depth the nature of the soil changes, often fairly abruptly. This change is brought about partly by the action of ploughs opening the soil to a particular depth, or by the natural limitations imposed upon the vegetation of the surface.

When a hole has been dug in a field, and a good vertical surface been obtained, it must then be decided how the slice is to be cut, and divided as regards depth. Where time 
permits, it will be advisable to separate the soil into a series of layers, the first three inches, the next three inches, a third three inches, and possibly a few further depths as well. A very large number of samples of soil have been taken to a depth of nine inches, and it is, therefore, desirable, for comparative purposes, that the amount of plant food to a depth of nine inches should be known, but it is often advisable to have further information. The great variation of composition which occurs in soils from depth to depth must always be borne in mind, since unless soils be sampled to a definite depth, no sort of constant results can be obtained. There are, however, many occasions when a soil is not nine inches deep, and one is, therefore, compelled to content oneself with less depth. Not infrequently within easy range of a spade from the surface one may come across rock more or less broken down by weathering. Many attempts have been made to obtain some mechanical appliance to obtain samples of soil with less labour than that involved in first of all digging a hole and then obtaining a vertical slice. Within the narrow limitations of particular types of soil such efforts are perfectly satisfactory, but a universal method for all soils has yet to be discovered, excepting the more laborious method here described. All instruments of the type of a boring tool become unworkable in a soil containing many stones, whilst in humus soils they introduce the serious difficulty of inaccurate measurement, owing to the compression of the soil which they produce. They further have the great disadvantage that the operator cannot see the nature of the soil he is sampling, and an observation on the spot of the actual appearance of the undisturbed soil will often teach quite as much as the subsequent analysis.

The size of the particles of soil is a matter of great practical importance. This subject has been investigated very fully, and much of the literature on the subject is given under such names as physical or mechanical analysis. The manner in which the particles are packed together is also a point of great importance. The actual size of the particles is not easily altered, but the manner in which particles are 
packed is subject to considerable control. If we assume, for the sake of argument, that all the particles in the soil are spherical, and that they are packed together with loose packing, then the air space will amount to 47 per cent. of the total. With close packing they will give 26 per cent. In practice, however, such purely theoretical considerations have little relationship to what actually occurs. The particles are not spherical, and, at any rate in a temporary manner, they put themselves into a condition known as " crumb " structure, in which the particles have built themselves up into irregular groups, with fairly large openings between groups of particles, so that in fertile soils the vacant space filled with either air or water amounts to about 50 to 70 per cent. Where there is much fibrous, half-decayed root, the openings of the structure, and consequently the air and water space; may be further increased. In the operation of tillage the earth is broken apart and allowed to fall back gently, so that the structure is much more open. Rolling will compact the soil and decrease the air and water content. For the growth and development of any root system space in the soil is necessary, and the provision of this necessary space is largely dependent upon tillage operations. The movement of the water in the soil is much altered by variations in the open space in the soil.

A very important study in the physical properties of soils consists in the consideration of the properties of colloidal material that the soil contains. A rough distinction between the colloids in the soil and the solid grains may be made by stirring the soil up with water, allowing the grains to settle for twenty-four hours, and pouring the muddy liquid off. Some portions of the soil will practically never settle in water, but may be made to do so by precipitating with suitable agents. The addition of sodium carbonate will increase the proportion of a soil that will not settle in water. The addition of calcium sulphate will precipitate nearly all the soil colloids. Any strong solution-sodium chloride and sodium sulphate-will also precipitate the colloids; super-phosphate, lime, basic slag, and farmyard manure all 
tend to reduce the colloidal condition of the soil. A certain amount of colloid is certainly valuable in light soils. At Woburn it has been observed that nitrate of soda removes colloids from the surface soils, and deposits them again deeper down, so that the surface soil loses its adhesive properties, and becomes too dry and sandy. On heavy soils too much colloidal matter makes the clay almost unworkable. It should be noted that fertilizers, in addition to their purely chemical value, have a powerful influence upon the colloidal character of the soil. It is doubtless perfectly possible that in a few special places this influence of the fertilizers on the colloids may help to overwhelm the influence of the chemical elements, but in most situations it will be found that the considerations given to the fertilizers in Part I. will be a fairly correct method of assessing the increment of plant production. Nevertheless, the secondary influence of the fertilizers upon the physical properties of the soil must never be overlooked, since it may produce some profound changes.

Personal observation shows that, on clay lands, basic slag produces an abundance of deep fibrous root, sulphate of ammonia a shallow black humus, and muriate of potash a black humus a few inches deep, with a sticky subsoil. On light soils, nitrate of soda gives a surface sand with hard pan subsoil.

Much depends upon the ability for growth of the surface vegetation, and this is illustrated in a striking manner in experiments on pasture land. At Cockle Park, in Northumberland, basic slag has been continuously applied to grass land, with the result that the soil has been steadily deepened, so that the active part of the soil on the surface has invaded the inactive subsoil underneath (see p. 29). No person today, who did not know the history, and was shown slices of the two soils, would imagine that they ever could liave been the same. This marked change in the soil has been brought.about by the increased root development of the natural vegetation, which has been encouraged to grow by the application of an appropriate fertilizer, in this case basic slag. It must not be imagined, however, that for any and 
every soil exactly that treatment would be the ideal one, but investigation on the soil itself will probably show what is most required. Similar results have been obtained on light soils by combined potash and phosphate fertilizers, whilst on some soils wild white clover seed harrowed in has produced the desired effect.

Owing to the colloids in a soil, it is difficult to filter a soil extract through paper. A soil will, however, always filter itself clear, since any sized particle will always find some particles a little coarser than itself, the interstices between which will always be smaller than itself. By fitting up a funnel with a filter disc and cloth, to which is adapted a long fall tube for suction purposes, and pouring the soil, mixed with water, into the funnel, the first cloudy runnings can be returned to the funnel and then a clear solution will be obtained. Hence the finest colloids do not penetrate very deeply into a soil.

Specific Gravity. - The true specific gravity of a soilthat is, the specific gravity of the particles of which the soil is composed-is not in itself a matter of much practical importance, though referred to in nearly all text-books. The crude gravity - that is, the weight of a given volume of soil, including air spaces-is, however, a distinctly useful figure. Commonly this measure is expressed in pounds per cubic foot. A sand will weigh IIo pounds per cubic foot when dry, a good arable soil from 80 to 90 pounds, a heavy clay 75 pounds. A soil containing very much decomposed organic matter will weigh about 70 pounds, whilst a peaty soil containing much fibrous organic matter will only weigh from 30 to 50 pounds per cubic foot. The soil on Tree Field, at Cockle Park, in its unimproved condition, weighs between 84 and 87 pounds per cubic foot, and, though a clay, contains a few stones and a little organic matter. The apparent heaviness of all the soils of the Cockle Park type is due rather to utter lack of balance than to the strict physical properties of the fundamental ingredients, a fact which is borne out by the above figures, which would classify this type of soil as having a much higher value than it has in its 
natural condition. Calculated to the weight of soil per acre, taken to a depth of eight inches, one acre would weigh a thousand tons; or to two decimetres, a million kilograms.

Sources of Heat to the Soil.-Although under conditions of market gardening and the use or the warm frame the amount of heat produced by chemical action may be apprcciable, in large-scale agriculture the only important source of heat is from the sun. The chief fluctuations of heat arise in (I) the photosphere of sun ("sun spots"), which produces indifferent harvests about once every ten or twelve years and fortnightly alternations of high and low temperatures; (2) the resistance of the atmosphere to the passage of solar radiant energy, a resistance which is greatly increased by clouds, moisture and fog; (3) the angle of incidence of the sun's rays upon the surface of the earth, which angle will vary with the season, the latitude, and the slope of the soil. Within the limits of the tropics, that is, $23^{\circ}$ north and south of the equator, at some period of the year the sun's rays are vertical, and, according to the proximity of the equator, the sun even passes away still further from the vertical. In the tempcrate zones the sun is never absolutely vertical, but owing to the increase in the length of days during the summer, the total amount of solar radiation received within the twenty-four hours exceeds that received in the tropics. The highest temperatures are recorded in latitudes of $30^{\circ}$ or thereabouts: at latitudes over $60^{\circ}$, solar radiation does not reach the optimum for plant production. Slopes having a southerly aspect in the northern hemisphere, or a northerly aspect in the southern hemisphere, are advantageous, since a definite quantity of solar radiation has then a smaller area to distribute itself over. In the northern hemisphere what the southern slope of a hill gains the northern slope loses.

Altitude is an important consideration in the growth of plants. In high altitudes the sun's rays fall upon the ground through a shorter, less dense, and clearer column of atmosphere. On the other hand, considerable lowering of temperature is produced on high altitudes by ascensional currents of 
air. When air rises from the plains to the hills it expands, and in expanding loses heat. The wind, therefore, rising from the plains to the hills, cools the tops of the hills.

In cold climates the removal of superfluous water by drainage is of great value in maintaining the temperature of the soil. Hoeing and harrowing also assist in this direction, and the use of any kind of mulch effects the same purpose. In hot climates irrigation not merely supplies water, but also lowers the temperature. Very shallow ploughing, harrowing, and hoeing make the surface a relatively bad conductor of heat, and, therefore, prevent the penetration of solar heat.

Colour of Soils.-Dark-coloured soils absorb and radiate more heat than light-coloured soils. In hot climates some of the black soils show very striking variations between the temperatures at 2 p.m. and 4 a.m., as is well known to those who camp out on them. In damper climates the black soils are orten visited by mist and fog. On the general average the black soils will have a higher temperature than light soils, since at night they will protect themselves from cooling by a local blanket of fog. Dark soils will accumulate more dew than the light soils, and are generally regarded with favour. The origin of the dark colour may be somewhat varied. It is most frequently due to organic matter, either produced by natural accumulations or by deliberate addition of organic manures. In gardens, in the vicinity of towns, black colour is often due partly to soot and cinders. The real source of the colour of the Indian black cotton soils has been much disputed. A red colour is generally due to ferric hydrate, a blue colour to iron in a lower stage of oxidation.

Conduction of Heat.-Air is a bad conductor, and, although silica is not a particularly good one, it is relatively better than air. Compact soils conduct heat best, and will vary in temperature most. Superficial tillage is, therefore, advantageous. Observations under experimental conditions at Cockle Park for very many years prove that cultivated soils show less variation in temperature than untilled land. The best conductors of all are moist gravels, which type of soil produces the earliest crops. Deep down in the subsoil 
the temperature is practically constant. At Greenwich Observatory at a depth of $25^{\circ} 6$ fect the seasons are reversed, with a difference of $3^{\circ}$ between summer and winter.

A very great deal of attention has been paid to what has been called mechanical or physical analysis of soils. In a district where one is dealing with geological strata which have never been seriously interfered with for many years past there is little doubt that these methods have considerable value, but where much farmyard manure and lime have been applied in the past, and the surface of the soil has been modified by road sweepings, then little value can be attached to any of these methods. The books in the bibliography should be consulted on this highly technical subject. The fertility of a soil is dependent upon an almost innumerable number of factors, and which one happens to be of most importance at the moment will depend upon an almost innumerable number of circumstances. For example, many square miles of the Punjab had for thousands of years borne few crops, but the introduction of irrigation has converted these areas into very fertile soils, growing large crops of wheat of first-class quality. Here the determining factor happens to be water, but the physical and chemical properties of the soil are the same. The problem is an engineering one. There are large areas of very poor pasture in the British Isles, such as occur in Northumberland in the north, and Sussex in the south. The, application of basic slag has revolutionized the whole character of such soils. Here the determining factor appears to be phosphorus, and possibly lime as well. In this latter case chemical analysis would have been of great value for information, but no single test, or group of tests, can possibly solve the problem of the fertility of a soil. All any such methods can do is to point out useful lines of investigation. It must then be left to the cultivator to experiment upon the land, and find out for himself what treatment is most satisfactory. The great value of both physical and chemical analysis lies in suggesting possible systems of improvement.

Capillarity. - As is well known, water will wet the surface 
of many materials. The grains of the soil are wetted by the soil water. The soil water adheres as a thin film to the grains, and when the grains are close enough together, the films unite, so that water can pass from the surface of one grain to the surface of the next, until equilibrium is reached. As a consequence of this fact, water will move through the soil by means of the films adhering to the surface of the soil grains. This action is often called capillary attraction, because it is more conveniently measured in tubes, but the problem is one of surfaces, and not tubes. When rain falls on the soil the water sinks downwards, partly because of the action of gravity, and partly because capillary equilibrium has been upset. When evaporation takes place from the surface, so that the films of moisture adhering to the soil grains become thin, then equilibrium is again established by water moving up from those grains which are more completely wetted. The rate of movement will be dependent not merely upon the motive power supplied by the difference of degrees of wetness in one part of the soil and another, and the motive power of gravity, but also upon the resistance due to the varying viscosity of the soil water, and the magnitude of the interstices between the soil grains.

It is a common observation that drains will run for a long time after rain has fallen. The resistance to the passage of water is large in proportion to the small motive forces, therefore velocity is low. As gravity is all the time acting upon any such water in the soil, the height to which water will rise by capillary action reaches a practical, if not an absolute, limit. It is for this reason that a mulch on the surface of the ground is so often valuable in conserving water. The water must rise through the soil quicker than evaporation can take place, otherwise the growing plant gets a very poor share of the water. The mulch allows water to reach a fair degree of concentration at the point where the plant roots are working. The height to which water will rise by capillary action in heavy soils composed of small particles is greater than in light soils composed of coarse particles, but soils of a coarse character will oppose much 
less resistance to the passage of water, and, therefore, facilitate rapidity of movement. The most suitable condition is cne intermediate, where neither the resistance to passage nor the lack of capillary attraction are too pronounced. Where soils have been recently broken up by tillage there will always be a space in the soil which is too large to permit of capillary attraction. The water will, therefore, be obliged to take circuitous routes when it rises, but the open spaces permit the penetration of the roots, which are thereby enabled to go down after the water. Deep tillage, whilst facilitating deep rooting, checks the upward movement of the water supply to the surface. Where rainfall is scanty, deep tillage is not satisfactory, because the seeds that are sown do not easily get enough water for their early stages of growth. Very shallow tillage dries up an inch or so of the surface, but protects the subsoil from loss by evaporation. In some special cases it is possible to obtain a combination of these different effects. When turnips are sown on land which has been put up into riggs and subsequently rolled, the roller only compresses the tops of the riggs, the furrows being untouched. With a "Cambridge" roller the pressure is mostly on the top of the riggs. Capillarity is, therefore, increased about the region where the seed is sown, but a mulch of loose earth remains in the furrows, and hinders the development of the weeds.

A point to be noted is that evaporation of water from a thoroughly wet soil is greater than that from an equal area of water itself, because the surface of a pond is practically smooth, whilst the surface of a soil is very irregular. As, however, a soil is by no means always thoroughly wetted, but is often dry, the total evaporation in a year from a soil is less than that of an equal area of water surface. At Rothamsted, I4 inches per annum represents the evaporation from the soil, and 18 inches per annum from a water surface. In many parts of the British Isles evaporation is greater than at Rothamsted, and in hot, dry countries the amount is still greater. At Alice Springs, in South Australia, evaporation amounts to ro3 inches per annum, and at Bombay it 
is 83 inches. Any green stuff growing on the surface of soil will increase the evaporation, hence weeds rob the soil of water. Loose stones on the surface decrease the rate of evaporation. In some parts of India stones that have been collected from the surface are carefully put back again as a mulch, but such a method is only possible in small types of cultivation. When water evaporates the soil shrinks in volume, owing to the removal of the water films, which separate the particles. In sandy soils this shrinkage is very slight; with humus soils the shrinkage is very large indeed. Clay soils shrink to an intermediate extent, but do not shrink in a regular manner, and generally develop cracks. These cracks tend to break the roots of plants, and, therefore, do harm at the time. The surface soil collects in the cracks and a slow inversion of the soil takes place. In other types of soil cracks rarely develop. Whenever water evaporates from a soil, loss of heat results, owing to the latent heat of steam, hence wet soils are also cold soils. When the surface is loosened by slight tillage, the water is kept in the soil.

At Cockle Park the moisture content on one occasion was Ir or per cent. of water where tilled, and 8.84 per cent. of water where untilled, and on another occasion I $3^{\circ}$ or per cent. where tilled, and 9.53 per cent. where untilled. In very hot, dry climates the capacity of dry soil to take moisture from damp air has some distinct value. Dry soil is distinctly hygroscopic. During the night, soils will radiate heat, but should they condense moisture on their surface the latent heat of the water vapour will check the drop in temperature. During the day the deposited water will evaporate once more, but this time the latent heat will check a rise in temperature.

Chemistry of Soils. - When any soil is heated, at first water is driven off, then complex gases are produced, and a certain amount of black charcoal left behind. The charcoal slowly burns off and leaves an ash, which is generally dark red in colour. During the first of these stages the amount of water that will be given off will dcpend upon the atmospheric conditions prevailing when the sample of soil was taken. When soils have been wetted by rain and allowed 
to drain for a considerable time, the amount of water remaining will vary according to the physical properties of the soil, as discussed above. In the case of sands and very light soils, from 5 to Io per cent. of water will be the amount commonly reached; whilst in the case of clays and heavy soils, from 30 to 50 per cent. will be held. When the conditions are very varied as regards rainfall, drainage, etc., the amount of water found will correspondingly vary (see p. 95).

The ordinary figures of analysis are generally reckoned on a soil which has been dried at $100^{\circ}$ Centigrade. In some cases reference is made to air-dried soils containing something between 2 and 5 per cent. of water. In other cases $120^{\circ}$ Centigrade is taken as the temperature for determining water. To obtain a soil in complete solution only very drastic methods will suffice. By ignition at a red heat the whole organic matter is driven off, and by the subsequent action of hydrofluoric acid the silica is volatilized, and the remaining substances go into solution. It is very rare indeed that the information obtainable by solution in hydrofluoric acid has any agricultural value, as neither the plant nor the soil bacteria nor atmospherical agents can possibly compare with hydrofluoric acid. The strongest acid commonly employed in the laboratory is strong hydrochloric acid. For many purposes the information obtainable from extraction by very weak solvents is of much greater value than information obtainable by more drastic chemical agents. Experience and convenience show that a solution of I per cent. citric acid, as recommended by Dr. Bernard Dyer, is one of the best of the weak solvents. It is usual in laboratories to shake a mixture of the soil with I per cent. citric acid by hand at intervals for three to six days, or to agitate in a mechanical shaker for about twelve hours. Of the ingredients usually discovered by chemical examination we have, among the mineral portions, the following materials :-

Iron.-This element occurs chiefly as ferric hydrate, and partly as ferric silicates, but, under exceptional circumstances, as ferrous compounds and pyrites. All fertile 
soils contain their iron in the ferric condition, lower conditions of oxidation are prejudicial to plant life.

Aluminium.-This element occurs in combination with silica. Substances like felspars are not infrequently present in soils. Those felspars which contain potassium are fairly resistant to weathering, but those containing much sodium are more readily weathered down. Clay soils contain a larger proportion of aluminium compounds than are found in sands. The aluminium probably plays but a small part in the chemical changes of the soil, excepting so far as it is one of the constituents of complex silicates.

Manganese.-Manganese is present in most soils to a very small extent, but occasionally the amount rises as high as I per cent. It is possibly an element of some importance, as it is found invariably in beech trees, and is a very common constituent of grass and root crops, but the amounts present are small. The red colour of the red beech leaf and red hair is believed to be due to manganese compounds.

Titanium is always present in soil to the extent of a per cent. or so, but is commonly left mixed with silica in analytical returns. It is not known to have any value.

Calcium. - This element is one of the most important in the soil. The most useful form is calcium carbonate, which by slow solution in water containing carbon dioxide becomes calcium bi-carbonate, an important agent in the process of nitrification, and in the flocculation of clays. Calcium sulphate is often present in small amounts. The oxidation of sulphur compounds in the soil will result in the production of calcium sulphate with the aid of some source of lime. Complex compounds of calcium with siliceous substances, and complex calcium compounds with organic materials, are of only slightly less importance than calcium carbonate. These compounds are respectively alluded to by the vague general terms of calcium silicates and calcium humates. It must not be supposed that the constitution of cither of these bodias is known. These names are only general terms expressing groups of compounds 
having certain common properties. When such substances as sulphate of ammonia come into contact with "calcium silicate or humate," the sulphuric acid part of the sulphate of ammonia combines with the calcium, whilst the ammonia enters into combination with the silicic or humic residue. Such actions are not so beneficial to the soil as the actions of the same fertilizer on calcium carbonate. It is only where plant production is carried out to a low degree that calcium silicate and humate can be considered as a substitute for calcium carbonate. Intensive plant production necessitates the presence of calcium carbonate. Water containing carbon jioxide can also react with these " calcium silicates or humates," producing calcium bi-carbonate. The presence of calcium carbonate can be detected by the degree of effervescence which is produced on the addition of hydrochloric acid. A little experience will enable one to judge fairly well of this point, but sodium carbonate and magnesium carbonate will give the same effervescence. For most purposes a knowledge of the carbonate present is of more use than a knowledge of the actual amount of calcium (see p. 75). Calcium carbonate checks "finger and toe " in turnips.

Magnesium.-Magnesium in the soil will generally occur as magnesium carbonate, magnesium bi-carbonate, complex magnesium silicates, magnesium humates, and, very rarely, traces of magnesium sulphate or chloride. Magnesium is certainly a necessity of plant life, and is stored in the cercal seeds to an appreciable extent. Soils very deficient in magnesia show beneficial results from the application of magnesium carbonate, but soils containing much magnesia usually show bad results from the addition of magnesium carbonate. A theory has been suggested that the ratio of magnesia to lime is important in plant life. A soil in County Durham, for example, which has failed both for agriculture and forestry shows $\mathrm{CaO}: \mathrm{MgO}:: 1: 9^{*} 2$. There is some evidence in support of this view, but it is so much disguised by other factors that at present the subject must be left open to doubt. There is no question that soils containing much magnesia are generally benefited by an 
application of lime, but that is also true of soils which contain but little magnesia. There is also plenty of evidence that the general balance of fertilizing ingredients in a soil is an important point, and whether the lime-magnesia ratio has any specially great importance beyond other ratios, say lime to iron, is a point which has not yet been satisfactorily settled (see p. 8).

Potassium.-Potassium occurs chiefly in the soil as felspars, hornblende, and other minerals. A fair proportion of potassium in the soil also occurs in combination with organic matter, which is commonly known as potassium humate. A certain quantity of soluble silicates containing potassium occurs in soil water. The proportion of potash extracted by weak acids is very small indeed, sometimes only a fiftieth part of the total potash in a soil is capable of being dissolved by a I per cent. solution of citric acid.

Sodium. - Sodium occurs chiefly in silicates of a complex type, which are not so stable as the corresponding potassium compounds. The action of weathering these silicates results in the production of sodium bi-carbonate, which, reacting upon the fine clay particles, produces a sticky and impervious mass. In some parts of the world, such as India and the United States of America, salt incrustations on soils are common, ruining many miles of otherwise good soil. Where there is little organic matter the incrustation is white, where there is much the colour is often black. The terms, reh, usar, white alkali, black alkali, are the common names for this type of soil. Lack of drainage is one of the chief causes of the serious accumulation of sodium salts in a soil. The addition of calcium sulphate in any form will result in flocculating the clay, and, therefore, in improving the drainage. The mere operation of cultivation will also assist in improving the drainage and thereby prevent the accumulation of soda. Sodium has no particular value to the soil, and is, therefore, often omitted from analyses.

Phosphoric Acid.-The only compounds of phosphoric acid that are found in the soil are derived from ortho-phosphoric acid. Phosphoric acid is, of course, a 
most important ingredient in soils. Probably phosphorus and nitrogen are the two most commonly lacking soil ingredients. Ferric hydrate in the soil is capable of combining with phosphoric acid and forming insoluble phosphates, which undoubtedly react to a limited extent with calcium salts, so that in the soil phosphorus will occur as phosphates of all the bases, and will also be found in the organic matter. Water containing carbonic acid is a better solvent of the complex phosphates than water itself, and the amount that will enter into solution will depend partly upon the concentration of carbonic acid in the water of the soil, which will in turn depend on the percentage of carbon dioxide in the soil atmosphere. Large amounts of iron in the soil hinder the solution of the phosphoric acid by carbonic acid.

Sulphuric Acid.-Sulphuric acid in the form of calcium sulphate is common in all soils, and is probably the chief source of the sulphur that is necessary for the formation of plant proteins. It is being incessantly regenerated in the soil itself by the oxidation of organic sulphur compounds acting upon lime, also present in the soil. In the vicinity of large towns the sulphur thrown into the atmosphere by the combustion of coal comes down with the rain, washes into the soil, combines with lime, and produces calcium sulphate. Where the amount of lime is insufficient, the soil becomes acid, and less fertile. Whenever super-phosphate or sulphate of ammonia are used, considerable quantities of sulphuric acid are added to the soil, so that modern conditions of agriculture near big industrial districts do not usually require the addition of sulphate to the soil, but agricultural districts far removed from industrial scenes may show a deficiency of this element.

Carbonic Acid.-Carbonic acid occurs in the soil both in the free and combined condition. When carbon dioxide in the air dissolves in water a certain amount of the true carbonic acid exists in solution, and acting upon any base present, produces bi-carbonate. When such soil is dried, and removed to the laboratory, an ordinary carbonate is formed. The amount of calcium carbonate in the soil 
is one of the most important points, since the effective use of most manures will be largely determined by its presence in sufficient amount. More than I per cent. of calcium carbonate is probably unnecessary, and less than I per cent. is probably only suitable to parsimonious systems of farming.

Nitric Acid.-The nitrates in the soil are very evanescent. The plant gradually sucks them up and is quite prepared to store them in the stem if it has the good luck to find more than a scanty supply. The bacteria in the soil will readily steal the oxygen of the nitrates if there is much undecomposed organic matter present. On the other hand, nitrates are being incessantly produced by the beneficial action of bacteria in the soil. The amount of nitrate in a soil is rather an evidence of the vigour of life in the soil than of anything else. Nitrates are washed out of the soil with great ease and rapidity.

The Organic Matter in the Soil.-The ordinary process of drying a soil in a water oven and then igniting gives a figure which represents both the organic matter and water of combination together. The latter figure is, of course, not constant, and depends upon the amount of hydrated silicates present. The figure for organic matter in a soil will, therefore, be nearer the mark in a sandy soil than it is in a clay soil. Much labour has been devoted to studying the organic matter in the soil, but it is such a very difficult problem that it is almost impossible to give any wide view of the subject. The mere estimation of the carbon will not give one much insight, whilst the efforts to extract so-called humic acid only touch the fringe of the question. Some idea of the amount of decomposed organic matter can certainly be obtained by a modification of Grandeau's method, that is, by first acidifying the soil, washing out all calcium compounds, extracting with dilute ammonia, and comparing the colours obtained. An estimation of nitrogen is certainly valuable, and helps to give one some idea of the amount of organic matter present. The ratio of carbon to nitrogen was investigated by Lawes and Gilbert at Rothamsted, who found that carbon was oxidized away from the soil 
faster than nitrogen. Those authors slowed that in farmyard manure the ratio $\mathrm{C}$ to $\mathrm{N}$ equals 25 to $\mathrm{I}$. In the top nine inches of old pasture the ratio was $I 3$ to $I$, but in the subsoil 6 to I. Some of the American workers on the subject have detected small traces of a variety of synthetic compounds, but it is very difficult to decide whether these are important or not. We have so many illustrations in living things of the extraordinary potency of small traces that it does not do to ignore little things, but until something more definite is known it is not practicable in a conspectus of this character to do much more than refer to the authors in the bibliography.

Available Plant Food.-A very distinct advance was made in soil analysis when Dr. Bernard Dyer introduced his method of attacking soils by I per cent. citric acid solution (see Bibliography). Dyer showed that for the less exhausting crops o.or per cent. of phosphoric acid or potash, soluble in I per cent. citric acid, represented the margin between fertility and need of manure. The method has also been found to apply to tropical soils. It has been pointed out that the method of Dyer is purely empirical and that if carried out under totally different conditions different results will be obtained, but the strength of Dyer's position lay in the fact that he correlated his metlod with actual experiments at Rothamsted, and that his conclusions have, in the main, been thoroughly well substantiated in most places where they have been tried. The objections raised against his method are only general objections to any single test; so far as a single test is capable of use at all, there are few single tests applicable to soils of such general utility as the phosphoric acid and potash soluble in I per cent. of citric acid. The relationship of the soil to the soil water, to the plant, or to a I per cent. solution of citric acid, are all cases of mass action. The statcment that repeated extractions with citric acid continue to dissolve more and more phosphoric acid from the soil is not a criticism of Dyer's method at all, but an explanation of the reason of its success. It is just because citric acid and carbonic acid and the plant in relation to the soil 
are all cases of reversible reaction, that the extraction with weak solvents is some kind of analogue to the life of the plant. The complete analysis of soils is given in many text-books, but only one or two illustrations can be found room for here. Whatever part of the world soils come from, there is some kind of resemblance. The following table, taken from a book by the author, gives the composition of a few Indian soils, to which have been appended one or two analyses from Northumberland.

TABLE I3.

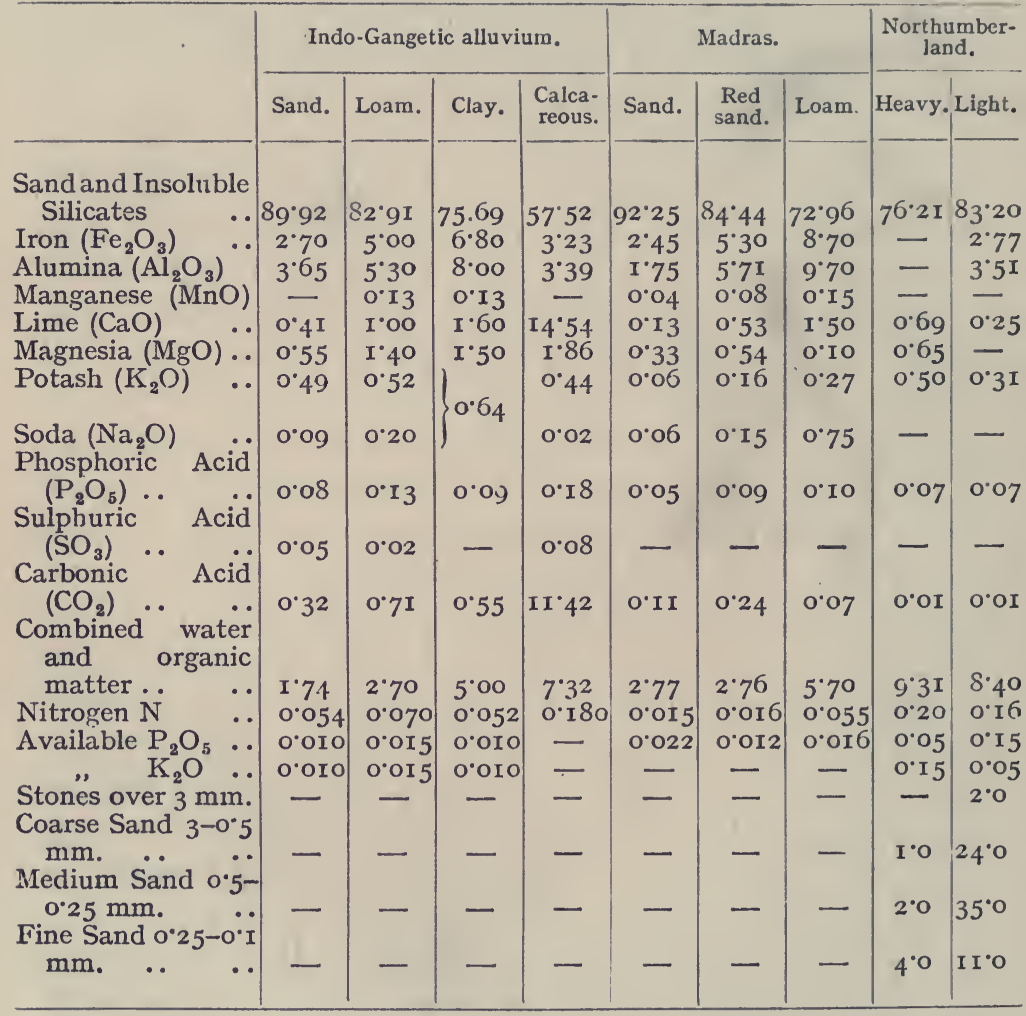

To interpret any soil analysis the most important points to consider are the following. Sand and insoluble silicates often give a clue to the physical condition of the soil. Luxmore showed the correlation between insoluble silicates 
and mechanical analysis. Soils containing large percentages of sand and insoluble silicates are of a light, sandy character, those containing low amounts are of a heavy clay character, unless, when we must always reconsider the results of physical analyses, the soil also contains much lime or organic matter. Soils containing much iron are hungry for phosphoric acid, though when supplied with phosphoric acid they usually become very fertile soils. The aluminium is an indication of the amount of clay present. Manganese has little general interest, although there is distinct evidence that small quantities of manganese are useful (see p. 9). The lime is a most important ingredient, and when the lime falls to low figures fertility is at a low ebb. Magnesia in small quantities is probably beneficial, in large quantities it appears to be harmful. The ratio of lime to magnesia is sometimes considered important. Where the magnesia exceeds the lime there is considerable evidence that the magnesia is harmful. The potash extractable by hydrochloric acid is a figure of no practical value. The phosphoric acid dissolved by hydrochloric acid should not fall below 0.I per cent. Sulphuric acid may be ignored except in districts where there is no coal smoke and little artificial manure used. The carbonic acid evolved in the cold by dilute acids is valuable as an indication of the amount of calcium carbonate in the soil. It will be noticed in the figures given that the organic matter and water of combination in Northumberland are very high in proportion to those in the Indian soils quoted. This is quite typical of the difference between cold and hot climates. The nitrogen is usually very low in well-cultivated soils in hot countries and high in forest or pasture in cold climates. The figures for nitrogen can only be taken in conjunction with other evidence. The available phosphoric acid and potash soluble in I per cent. citric acid form some of the most useful figures in the table. Much, of course, will depend upon the kind of crop grown, but for crops of no great exhaustive character, o.or per cent. will make a good dividing line between fertility and need of manure. In considering the chemistry of soils one should consider rather 
the balance of the ingredients than their absolute amounts (see p. 8). Exactly what balance is necessary for any set of circumstances is only approximately known, and the actual cultivator will need to experiment for himself on his own soil.

Nitrification in Soils. - The air in the soil differs from ordinary air in that it contains less oxygen and more carbonic acid, owing to the oxidation of organic matter in the soil by the action of the air. As two volumes of oxygen produce two volumes of carbon dioxide, this change does not effect the percentage of nitrogen. Some small quantities of nitrogen may be taken out of the air by nitrogen fixing bacteria, and some small quantities of nitrogen may be added by denitrification. The atmosphere in the soil and the ordinary atmosphere above the surface diffuse into one another. The rate at which this diffusion will take place is lessened by compression, but is fairly independent of the fineness or coarseness of the particles of the soil. The effect of rolling the soil will be to first compress the soil, prevent diffusion taking place, and, therefore, increase the percentage of carbon dioxide. When the percentage of carbon dioxide in the soil-air increases, the amount of carbon dioxide dissolved in the soil water will also increase, since the amount dissolved depends upon the partial pressure of the carbon dioxide.

As the amount of carbonic acid dissolved in water increases, so the solvent action of the soil water increases at the same time. Rolling, however, by checking the diffusion of fresh air into the soil, lowers the percentage of oxygen and discourages oxidizing bacteria. The ultimate effect of rolling the soil is, therefore, to increase the supply of phosphorus and potassium to the plant, and decrease the supply of nitrogen. Opening up the soil by harrowing produces the opposite effects. These effects are, however, very temporary, since secondary results, due to bacterial life, quickly come into play. In addition to the soil atmosphere considerable quantities of gas are occluded on the surface of the soil particles. Ferric hydrate is particularly powerful in this respect. Peat, and all other forms of organic matter, are 
also good substances for occluding gas. Gases occluded on the surface are more active than ordinary gases, but little work has been done to follow up exactly what effect this has upon soil life. The action of occluded gas is probably generally overwhelmed by bacterial actions, to which much more attention has been paid. Russell and Hutchinson have shown that, in addition to the bacteria in the soil, there are considerable numbers of bacterial enemies, which reduce the numbers of the bacteria. Whether the idea that soil amœbæ and paramecia play the part of microscopic beasts of prey is a true or only a fancy picture has never been determined, but the ultimate results have been the subject of careful investigation. Certain organisms living in the soil are able to fix nitrogen, provided they can obtain organic matter in some way, and provided they can obtain a proper supply of phosphates and potash (see p. 29).

At Cockle Park, in Northumberland, the amount of nitrogen in the soil has been steadily increased by the application of phosphatic manures. The plot which received no manure has steadily decreased in its nitrogen content from 0.197 per cent. nitrogen in 1899 to 0.174 per cent. in I9I6, whilst the plot that was treated with basic slag reached 0.227 per cent. nitrogen in 1908 and $0^{\circ} 244$ per cent. in I9I6. All these figures refer to the top six inches of soil, and have for the most part been done in duplicate or triplicate, showing probable errors varying from nothing to 0.008 per cent. Other plots with other treatments have shown somewhat similar results. That this fixation of nitrogen is by no means purely superficial is also shown in these Cockle Park experiments by taking the soil to each three inches depth. In IgI 6 the unmanured plot gave at each three inches step the following figures: $0^{\circ} 217,0^{\circ} 131,0^{\circ} 100,0^{\circ} 070$, and the corresponding figures for the manured plot were, $0.304,0.184$. $0.137,0.100$. It will be noted that the improvement is very marked in the top three inches, slightly less marked in the next three inches, while in the depths from six to nine inches, and from nine to twelve inches, there is still a steady increase. The gain in nitrogen is clearly still proceeding at all layers 
in the soil, and is still going down deeper and deeper. The fixation of nitrogen in soil is usually dependent upon the presence of leguminous crops. At Cockle Park the leguminous crop concerned is undoubtedly wild white clover, but in different parts of the world other leguminous crops would play the same part. Nitrogen that has been fixed in the soil, or obtained in the soil by any other means, is converted by other soil bacteria into nitrites and nitrates. It is the latter that form the nitrogen food of the plant. Much can be done in practice to improve the rate at which nitrification proceeds. In calcareous soils the nitrification proceeds at a much greater rate than in soils deficient in lime. Clays can be made to nitrify much faster if they are opened up so that they admit air. The chief requirements for the oxidation of nitrogenous matter in the soil are air, warmth, moisture, and lime. Tillage and bulky manures will supply more air to the soil, and control the water supply as well. Lime may need to be added directly to the soil. When the soil is closely packed, saturated with water, and air excluded, denitrification may occur (p. 5I). The fixation of nitrogen in the soil by soil bacteria is facilitated by a good supply of suitable organic matter, such as the straw in farmyard manure, phosphatic manure, a good supply of potash, and satisfactory conditions for the growth of the bacteria.

Soils and Fertilizers. - The relationship between the soil and the fertilizer used is an important point that must be considered. To some extent this has already been discussed in Part I. Generally speaking, lime is a necessity for the sound working of any of the fertilizers, with the exception of basic slag and calcium cyanamide, which both contain a certain amount of lime. Soils that are very deficient in one of the ingredients will respond specially to that particular ingredient at first, but it not infrequently occurs that as soon as one has satisfied the main need of the soil, a second order of necessity makes its appearance. There are many soils whose chief demand is phosphate, and very little good can be done to such soils until phosphates have been supplied. Afterwards 
potash and nitrogen may have their turn in producing satistactory crops. In other words, we go back again to the old proposition that the soil requires a certain balance of ingredients, and, however lacking the soil may have been once upon a time, in one ingredient, if you persist in supplying this ingredient there may come a time when the chief necessity of the soil is something else altogether. Much harm has been done in the past by the "rule of thumb" man in this respect. In the relatively early days of agriculture, manuring with animal refuse was practised to a large extent. At first this process was good, but it very speedily became overdone; then the fashion for applying lime set in. At first this was very necessary, because it had been neglected in the past, but that, too, soon became overdone. Then a fashion for the artificial manures, generally phosphatic ones, set in which have often been exhaustive of lime in the soil. To-day the needs of agriculture in populous countries are often more connected with the mismanagement of the past than with any other one factor. In taking up land, therefore, the past agricultural history is always a matter of great importance. The analysis of the soil will assist in checking the history of past good or bad management.

"The Law of Diminishing Returns" is now a recognized principle. When a manure is applied in increasing quantities it does not produce a corresponding increase of each additional amount of manure. The table on p. 84, gives the standard illustration from Rothamsted, in which it will be noted that a steady increase in the amounts of ammonia compounds soon becomes unprofitable.

Whether a particular increase of crop obtained from a particular quantity of manure is, or is not, profitable, depends upon the prices of both. Whilst in the above table 89 bushels of wheat per acre may be a profitable return for 200 pounds of ammonium salts, yet if the ammonia became cheap and the wheat dear, the 4.5 bushels of wheat as returned from 200 pounds of ammonium salts might also be very profitable. In other words, intensive cultivation which 
TABle 14.-Crop Yields with Increasing Nitrogen Supply, ROTHAMSTED.

\begin{tabular}{|c|c|c|c|c|}
\hline \multirow[b]{2}{*}{, } & \multicolumn{2}{|c|}{$\begin{array}{l}\text { Wheat grain. } \\
\text { Bushels per acre. }\end{array}$} & \multicolumn{2}{|c|}{$\begin{array}{l}\text { Wheat straw. } \\
\text { Cwt. per acre. }\end{array}$} \\
\hline & & $\begin{array}{l}\text { Increase per } \\
200 \text { lbs. am- } \\
\text { monium salts. }\end{array}$ & & $\begin{array}{l}\text { Increase per } \\
200 \text { lbs. am- } \\
\text { monium salts. }\end{array}$ \\
\hline Mineral manure alone per acre .. & 14.5 & - & I2.1 & 一 \\
\hline $\begin{array}{l}\text { Mineral manure }+200 \text { İbs. ammo- } \\
\text { nium salts per acre } . .\end{array}$ & $23 \cdot 2$ & 8.7 & $2 \mathrm{I}_{4}^{4}$ & $9^{\circ} 3$ \\
\hline Mineral manure + 400 lbs. ammo- & & & 214 & 93 \\
\hline $\begin{array}{l}\text { nium salts per acre } \ldots \\
\text { Mineral manure }+600 \text { lbs, ammo- }\end{array}$ & $32 \cdot I$ & $8 \cdot 9$ & $32 \cdot 9$ & II'5 \\
\hline $\begin{array}{l}\text { Mineral manure }+600 \text { lbs. ammo- } \\
\text { nium salts per acre } \quad . .\end{array}$ & $36 \cdot 6$ & $4 \div 5$ & $4^{I} \cdot I$ & $8 \cdot 2$ \\
\hline
\end{tabular}

is profitable when prices of produce are high becomes unprofitable when prices are low. Doubtless if every user of artificial fertilizers were to start using artificial fertilizers in double quantities because the rise in agricultural produce justifies such a procedure, then the prices of the agricultural fertilizers would rise so high as to put a stop to their economic use. Exactly where the dividing line between what is practicable and what is not must be determined in every case by the cultivator of the soil himself.

\section{REFERENCES TO SECTION I}

Leake, "Some Preliminary Notes on the Physical Properties of the Soils of the Ganges Valley, more especially in their Relation to Soil Moisture," Journ. Agric. Science, i., p. 454.

Keen, "The Evaporation of Water from the Soil," Journ. Agric. Science, vi., p. 456 .

Luxmore, "The Soils of Dorset," pp. 7, Ir.

Russell, " Soil Conditions," pp. 75, 87. (I.ongmans.)

Hilgard, "Soils," pp. 83, r07. (Macmillan.)

Hall, "The Soil," pp. 48, I54. (Murray.)

Fream, "Soils and their Properties." (Bell.)

Warrington, "Physical Properties of Soils." (Clarendon Press.) p. 3 I2.

Tempany, "The Shrinkage of Soils," Journ. Agric. Science, viii.,

Balls, "The Movements of Soil Water in an Egyptian Cotton Field," Journ. Agric. Science, v., p. 469.

Alway, "Studies of Soil Moisture in the 'Great Plains ' Region," Journ. Agric. Science, ii., p. 333.

Leather, "Memoirs of the Department of Agriculture in India," Feb., I908, p. 79; July, 1907, p. 49; April, I906, p. 3 ; and Feb., I900, p. 125. (The Imperial Department of Agriculture in India.) 
Leather, "The Agricultural Ledger," r898, No. 2, p. 22. "The Water of the Soil," p. ro. (Government Printing Office, India.)

Hall and Miller, "The Effect of Plant Growth and of Manures upon the Retention of Bases by the Soil," Proc. Royal Soc., B, vol. 77, 1905, p. 30.

Hall, Brenchley, and Underwood, "The Soil Solution and the Mineral Constituents of the Soil," Journ. Agric. Science, vi., p. 278.

Collins, "Scheibler's Apparatus for the Determination of Carbonic Acid in Carbonates," Journ. Soc. Chem. Ind., 1906, p. $5 \times 8$.

Collins, "Agricultural Chemistry for Indian Students," p. 44. (Government Printing Office, Calcutta.)

Russell and Appleyard, "The Atmosphere of the Soil ; its Composition and the Causes of Variation," Journ. Agric. Science, vii., r.

Schreiner, Journ Phys. Chem., 1906, p. 258.

Dyer, "A Chemical Study of the Phosphoric Acid and Potash Contents of the Wheat Soils of Broadbalk Field, Rothamsted," Proc. Roy. Soc., I907. p. II.

Miller, "The Amount and Composition of the Drainage through Unmanured and Uncropped Land, Barnfield, Rothamsted," Journ. Agric. Science, i., p. 377.

Russell," Washing-out of Nitrate from Arable Soil during Past (1915-16) Winter," Journ. Board of Agriculture, 1916-1 7, p. 22.

Lawes and Gilbert, "The Rothamsted Experiments."

Gilchrist, "Guide to Experiments," r917. (Ward, Newcastle.)

Hall and Amos, "The Determination of Available Plant Food," Journ. Chem. Soc., I906, T. 205. 


\section{SECTION II.-SPECIAL SOIL IMPROVERS}

Lime.-The exact dividing line between what constitutes a fertilizer and what constitutes a soil improver is rather difficult to determine, but whilst farmyard manure is commonly considered a fertilizer, since it contains nitrogen and potash, yet lime is usually looked upon from a different point of view. The lime is applied to the soil for the purpose of modifying the soil. The standard article is quicklime, produced by burning limestone. This is sometimes applied in big lumps, called shell lime, but it is much better reduced to powder, either by actual grinding, or by slacking with water, when it crumbles down. A high quality burnt lime will contain from 90 to 95 per cent. of lime, and this type of lime should always be used for agricultural purposes. A low quality lime, such as the following:-

TABLE 15 .

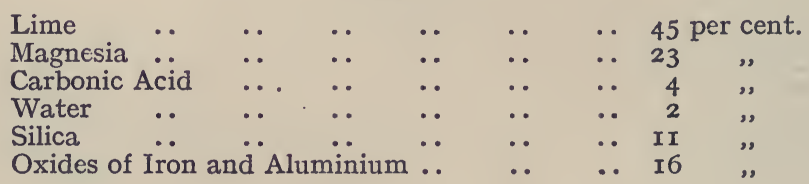

is of no use for agricultural purposes. Lime is sometimes employed to increase the ratio of lime to magnesia, for which purpose the lime in Table $I_{5}$ is very nearly useless. Lime, like other materials, should be distributed as evenly as possible, although this may not be quite so critical a point as it is in other fertilizers. One of the purposes for which lime is necessary in a soil is to assist nitrification. Calcium bi-carbonate in solution will rise and fall in the soil, according to the dry or wet weather, though it will not diffuse laterally. 
Nitrification will, therefore, proceed either above or below a lump of lime material, but it is much better to get a small dressing well distributed than to depend upon haphazard heavy dressing. The lime, as soon as it is applied to the soil, combines with water and forms calcium hydrate, and then absorbs carbonic acid, forming calcium carbonate. Lime also enters into combination, at any rate in a temporary manner, with the organic matter and clay. The addition of lime to a soil increases the amount of available potash and available nitrogen. It does not increase the amount of available phosphorus, excepting in the case of soils containing much organic matter, where a considerable fraction of the total amount of phosphorus in the soil is in some form of organic combination. Lime, when turned into calcium bi-carbonate, coagulates clay, and opens up nearly all types of soil. It is, therefore, particularly suitable for the heavier types of land. As it tends to dry out clay soils, lime should be applied fairly early, otherwise the soil may be too dry for satisfactory germination of the seeds. Lime is especially necessary with high farming. Superphosphates, sulphate of ammonia, nitrate of soda,kainit, farmyard manure and organic nitrogen manures all demand lime in the soil. There are a great many forms of industrial waste lime which can be used, the relative values of which depend upon the amount of calcium contained. When limestone is burned it loses about 40 per cent. of its weight, and the subsequent cost of carriage is that much less. It may be cheaper to burn coal in the lime kiln, and thus to reduce the weight, than to burn coal in a steam engine for the purpose of carrying useless carbonic acid. These varied forms of calcium carbonatc can only be considered it they are relatively cheap. Very considerable quantities of waste lime are produced in the "Leblanc" soda process. Calcium sulphide obtained as a by-product is treated with carbon dioxide in water with the evolution of hydrogen sulphide, then used for manufacture of sulphur. The waste calcium carbonate is run into heaps and allowed to dry spontaneously. This material, often called "Chance" mud, or lime mud, has proved a perfect 
substitute for lime, but it does not contain more than about 40 per cent. pure lime and has to compete with lime of 90 to 95 per cent. purity in the case of burnt lime. It is not possible to convey it by rail any considerable distance, as the railway freight soon swallows up any advantage of low price. In spite of the fact that the "Chance" mud is a fine precipitate, it runs together in lumps in the soil and is as difficult to distribute as shell lime. Lumps of "Chance" mud can be found in a soil many years after application. Another residue of a similar type is produced from magnesian limestone by the extraction of the magnesia for industrial purposes. The waste is very similar to "Chance" mud, as the amount of magnesia not extracted is very small. Where chalk is obtainable, treating soils with chalk is a wellknown process. Even when the soils lie on the top of the chalk, the surface sometimes contains but little lime. Chalk pits are dug in the fields, and the chalk then distributed on the surface. Building mortar can also be employed as a source of lime. The residue of acetylene gas-plants provides a very pure source of calcium hydrate. In a very crude form one may find lime from skin dressers and many small industries.

The effect of gas lime depends on sulphur and cyanogen far more than upon the amount of lime contained. Fresh gas lime contains considerable quantities of calcium sulphide, which oxidizes on keeping to calcium sulphite. Up to that stage oxidation is rapid, but the further oxidation of calcium sulphite to sulphate in a heap of gas lime is slow, although once it has been distributed in the soil the action is moderately rapid. In addition there are sulpho-cyanides, ferrocyanides, and sometimes cyanides themselves. These are all poisonous bodies, and hence the action of gas lime depends on partial sterilization (p. 90). Gas lime contains about 30 or 40 per cent. of calcium carbonate, and when the other substances have had time to decompose, this material produces its effects. A most important lime compound with very different properties is gypsum (hydrated calcium sulphate.) This has no practical resemblance to burnt lime, and its action 
on the soil is totally dissimilar. The great advantages of gypsum lie (I) in the fact that it is a sulphur compound, and sulphur is necessary for the formation of proteins; (2) that it decomposes sodium carbonate in the soil, and coagulates colloidal clay better than any other substance. When clay has been puddled by excessive application of nitrate of soda, and injudicious working in wet weather, calcium sulphate is an admirable cure. At one time plastering soils was a well-known process, much recommended for the growth of clovers. It has gone out of fashion in the British Isles, but the use of gypsum is still important in many parts of the world, and the experience of the British Isles must not be taken to apply everywhere. The reason why gypsum has gone out of fashion to such a large extent is that calcium sulphate is applied to the soil with other materials. Superphosphates contain more than half their weight of calcium sulphate. Soils, therefore, that have been liberally treated with super-phosphate are likely to be overcharged with calcium sulphate. Sulphate of ammonia applied in one year of a rotation, and lime applied in another, will produce calcium sulphate in the soil. Owing to the powerful action of gypsum it is still much believed in by some horticulturists, whose duties are often to break up very unsatisfactory land and grow crops with as little delay as possible. Hills composed of little but gypsum occur in some parts of the world, and as it is mined very easily, such local deposits of gypsum should always be carefully considered by those cultivating land at no great distance.

In the vicinity of large towns sulphur in the form of sulphuricacid is brought down by the rain with the subsequent formation of gypsum in the soil. On the whole gypsum reacts with the soil as an acid whilst lime reacts as an alkali.

The Use of Electricity in Plant Stimulation.-This subject has attracted much attention for many years past. It is such an obvious idea that the original suggesters are probably many in number, but one of the foremost workers in the first days of any substantial results was Professor 
Lemström. He succeeded by using electricity at a high tension conveyed by wires over a ficld. He employed an ordinary town current to drive a small electric motor, driving in its turn a small influence static electric machine. Subsequently the work was taken up by Professor Priestley at Bristol and Leeds. The method now adopted is to use a transformer with a rectifier to give positive electricity at a high tension. The details have by no means yet been worked out. But the latest ideas suggest that wires are best distributed overhead at about five feet in height, and that the wires should be made as thin as possible. Under these conditions a very marked increase in crops has been obtained. The actual cost of the electric energy is quite small, but the initial expense of the machinery is considerable, and at present requires skilled attention. Until details have been worked out on the large experimental scale, it will be difficult to make a commercial success of this method. Many points remain yet to be discovered, such as the relationship of light and varying humidity of the air, the strength of the discharge, and the relationship between electrification and the manure used. All these points require to be investigated thoroughly. The great advance, however, which has been made since Lemström's days by Priestley, Jorgensen, and Blackwood promises future progress.

The Partial Sterilization of Soils.-It is a very old, well-known fact that the application of heat, and all kinds of poisonous substances to soils, may increase the ultimate crop obtained, even though some injury may occur at the moment. From the elementary cottage idea of putting a flower-pot into the oven for a short time, up to the laboratory researches of Dr. Russell, the subject of application of heat to a soil has been freely discussed. In nature this process occurs in hot climates where solar radiation may raise the surface temperature of the soil up to $60^{\circ} \mathrm{Cent}$. ( $40^{\circ} \mathrm{Fahr}$.). Under these conditions many pests in the soil are destroyed, so that the ultimate growth of the crop is improved. In greenhouses steam is not infrequently employed for the purpose of heating the soil on a moderately large scale. In a similar way all 
germicides of a mild character, such as naphthalene, and even copper sulphate, and zinc sulphate, have been used with ultimately satisfactory results. Recent researches have shown that this treatment involves the destruction of all kinds of harmful organisms, from wireworms or millipedes, down to microscopic forms like the amœbæ, paramecia, etc., the larger of which directly injure the plant, and the smaller of which destroy the useful nitrifying bacteria. The destruction of pests soon produces an improvement in the crop, whilst the destruction of the enemies of the nitrifying bacteria results in an increased production of nitrate, with a subsequent increased production of plant growth. Heat also produces chemical and physical changes in the soil. The apparent results of heating the soil with steam are very similar to those of the action of frost-the soil becomes lighter, easier to work, easier for the plant to establish its roots, richer in soluble mineral matter, and the organic matter is more easily converted into ammonia and nitrates by the organisms in the soil. The application of heat is certainly the most efficient of these methods, but is not very easy to conduct on a large scale. Direct baking is probably one of the best methods, but steam heating is also very satisfactory. The application of germicides is so much easier to carry out that it has attracted a great deal of attention. Gas lime, the waste product from purification of coal gas, contains sulpho-cyanides, ferro-cyanides, and other poisonous substances. Occasionally, when the gas lime has been applied to pasture, the iron in the green grass is turned to Prussian blue, owing to the action of the cyanogen compounds in the gas lime. The sulphides and sulphites in the gas lime no doubt also play thcir part in acting upon all forms of soil pests. After the stlphides and sulphites and cyanogen compounds have been oxidized, the residue acts as a fertilizer. Calcium carbide has also been used. Naphthalene is another favourite soil fumigant. Crude naphthalene is a fairly cheap article, and not difficult to distribute. It is mixed with cole dust, gas lime, or ashes, for the production of many patent mixtures, which usually 
contain about 30 to 50 per cent. of crude naphthalene. These mixtures are rather drier, and more convenient to handle.

Soot may be considered to have a value partly dependent on tar and other poisonous materials.

There is considerable reason for supposing that many of these poisonous substances do some slight injury to the crop, but if the destruction of wireworms, etc., is on a sufficiently large scale, the subsequent benefit will more than compensate for the temporary injury. It is desirable that all these substances should be applied to the soil at a considerable interval of time before sowing seeds. If that is not practicable some slight good may perhaps be done by applying such germicides between the drills, so as to keep as far away from the plant as possible, but this latter practice must be considered as open to some objections. Injudicious use of soil fumigants has done much harm.

\section{REFERENCES TO SECTION II}

Russell, "Chalking: A Useful Improvement for Clays overlying the Chalk," Journ. Board of Agriculture, 1916-1 7, p. 625.

Hutchinson and Maclennan, "Studies on the Lime Requirements of Certain Soils," Journ. Agric. Science, vii., p. 75.

Collins, "Scheibler's Apparatus for the Determination of Carbonic Acid in Carbonates," Journ. Soc. Chem. Ind., 1906, p. 518.

Roscoe and Schorlemmer, vol. ii., p. 290.

Lemström, "Electricity in Agriculture and Horticulture."

Jorgensen and Priestley, "The Distribution of the Overhead Electrical Discharge employed in Recent Agricultural Experiments," Journ. Agric. Science, vi., p. 337.

Blackman and Jorgensen, "The Overhead Electric Discharge and Crop Production," Journ. Board of Agriculture, I9I 7-1 8, p. 45.

Russell and Petherbridge, "Investigations on "Sickness" in Soil," Journ. Agric. Science, October, 1913. Russell, "Partial Sterilization of Soil for Glasshouse Work," Journ. Board of Agriculture, IgII-12, p. 809; I9I2-I3, p. 809 ; 19I4-15, p. 97.

Russell and Hutchinson, "The Effect of Partial Sterilization of Soil on the Production of Plant Food," Journ. Agric. Science, October, 19og.

Buddin, "Partial Sterilization of Soil by Volatile and Non-Volatile Antiseptics," Journ. Agric. Science, vi., p. 4I7.

Russell, "Soil Conditions," p. II 4. (Longmans, Green.),

Wentworth, "Effect of Electricity on Sheep Raising," Journ. Board of Agriculture, I9I I-I2, p. 5 I9.

Brenchley, "Inorganic Plant Poisons." (Camb. Univ. Press.)

Hanley, "Lime and the Liming of Soils," Journ. Soc. Chem. Ind., I918, p. I85 T. 


\section{SECTION III.-SOIL RECLAMATION AND IMPROVEMENT}

Barrenness.-Very large numbers of soils are not producing anything approaching to their maximum crop, although one cannot definitely classify them as being under the well-recognized types of land difficult of cultivation. These lands are only partially barren, from improper treatment due frequently to economic causes.

The supply of plant food in the soil is sometimes the chief cause for the difference between productive and unproductive land. Table 16 shows the amount of plant food in productive and unproductive types of soil.

TABLE 16.-Composition of SoILS.

Parts per Two Million or Pounds per Acre to a Depth of Seven Inches.

\begin{tabular}{|c|c|c|c|c|c|c|}
\hline \multirow{2}{*}{\multicolumn{3}{|c|}{ Elements of plant food. }} & \multicolumn{2}{|c|}{ Very productive soils. } & \multicolumn{2}{|c|}{ Non-productive soils. } \\
\hline & & & $\begin{array}{l}\text { Holland } \\
\text { alluvium. }\end{array}$ & $\begin{array}{c}\text { Scotland } \\
\text { wheat soil. }\end{array}$ & $\begin{array}{l}\text { German } \\
\text { barrens. }\end{array}$ & $\begin{array}{l}\text { Maryland } \\
\text { barrens. }\end{array}$ \\
\hline Phosphorus & . & $\cdots$ & 4,100 & 3,780 & trace & I 80 \\
\hline Potassium & .. & .. & 17,040 & 5,880 & none & 2000 \\
\hline Calcium .. & .. & $\therefore$ & 58,460 & 17,560 & 1380 & 580 \\
\hline
\end{tabular}

A very common cause of unproductiveness in a soil is the lack of proper plant food. There are many other causes, but there are few of them quite so common as the question of the supply of proper mineral plant food in the soil. That the supply of plant food in the soil is a very fundamental question is illustrated in Table $I 7$, which shows the relative supply and demand of the most important elements of plant tood, and it will be noted on purely fundamental grounds 
that the total amount of phosphate in the crust of the earth is not super-abundant for the purpose of wheat production.

Table 17.-Relative Supply and Demand of Elements in EARTh and Plants.

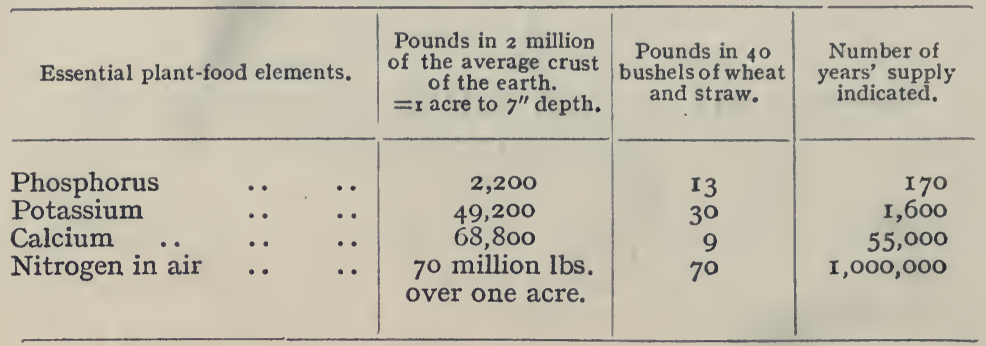

There are many districts in the world which we know have been cultivated for at least a few thousand years, but the amount of phosphorus in the earth's crust, as shown in this table, would only justify us in the conclusion that we could grow bumper crops for I70 years. A commonly occurring deficiency of phosphorus is, therefore, to be anticipated. The other causes besides the lack of plant food are excess or deficiency of moisture, indifferent physical condition, absence of beneficial or presence of harmful soil organisms, or the presence of some substances injurious to plant life. In sandy soils the lack of colloids is so detrimental that almost complete sterility may occur. The ordinary sand on the sea-shore, for example, is very barren, owing to the action of the sea water having washed out all colloidal material. A few struggling plants may manage to make themselves at home, and gradually add a certain amount of humus to the soil, after which the general growth of plants may begin.

Dry Lands.- Land that is too dry and has too little natural water is one that requires some system of irrigation to be thoroughly satisfactory. Irrigation generally has to be obtained by some reservoir system of water supply. Where large rivers are obtainable, as in the northern parts of India, and in the case of the Nile Valley, dams can be placed across the rivers. On dry lands shallow tillage is essential. For 
this purpose the most suitable source in dry climates is a river which can be relied upon to run in dry weather. Such are, however, scarce, and are chiefly to be found in rivers that travel from long distances, or originate in snow mountains. The rivers originating in the Himalayas are specially suitable for this purpose, since the melting of the snows in the summer gives ample supplies of water. The Nile, rising a great distance away, gives a flow of water at the right time. The erection of dams or barrages across the river will hold the water up, and divert it into proper channels, which then communicate with distributing channels of smaller size. The supply of water by these means depends upon the organization of distribution. In Madras, and many parts of India, very old-established tanks occur, which have been originally produced by the utilization of some natural depression by building a dam across the original outlet. The rainfall is collected from a small area, but the natives collect considerable quantities of water in the rainy season, and utilize it in the dry season. When the water from such tanks has been let out, the wet, muddy bottom is used for cultivation of rice. From such large, open tanks the loss of water by evaporation is very considerable. The expense of instituting such a system would be very heavy, but nearly all these somewhat primitive arrangements have been produced by degrees, mostly utilizing labour which would otherwise have been wasted. The water is applied to such dry lands by running the water along channels, the distance between which will depend upon the type of crop grown. There is a great tendency on the part of the users to take more than is necessary. Deep ploughing only lets the water of the subsoil evaporate. Mulches should be used as much as possible. Many soluble manures, especially phosphates, economize water. Nitrogenous manures, such as sulphate of ammonia, if applied when the plant is suffering from drought, may often increase the crop.

Wet Lands. - Wet lands require, as a rule, drainage. Drains should be set not too deep, and should lead without any very sharp angles into the main drain. By such a 
system of drainage not merely is the water removed, but also air is let into the soil. In certain particular cases, as, for example, some of the fens, the soil may be alternately wet and dry. In these fen districts it is not uncommon that the level of the rivers and canals exceeds that of the fields. In this particular case a ditch is dug bctween the field and the river. The level of this is below the level of the field, and considerably below the level of the river. Into this main ditch branch channels run to carry the surplus water, which is pumped into the river at a higher level. When dry weather intervenes, it is only necessary to reverse the action of the pumps, and let the water run back into the ditch from the river, and thence into communicating channels. Very large quantities of rank grass may be obtained by such a method. Many of the grasses which normally have a very bad name owe their lack of nutriment to a big development of fibrous stalk. Under conditions of perpetual moisture these grasses never mature, and are, therefore, always moderately succulent.

One of the results of bad drainage in a soil is a tendency to accumulate poisonous materials. When the clay constituents of a soil contain large amounts of soda, the soda is removed from the clay by the action of water containing carbonic acid, producing sodium carbonate, which deflocculates the soil. One of the cures for this is drainage which removes the soda salts. The application of gypsum to such a soil converts the sodium carbonate into sodium sulphate which washes away with rain, and leaves calcium carbonate behind. The former is relatively harmless and drains away in time, the latter is beneficial. Sodium sulphate does not hinder the germination of seeds as much as sodium chloride or sodium carbonate. This type of land is known in America as the black alkali land, whilst in India it is known as reh or usar. As on many poor soils, persistent efforts at cultivation result in improvement. Where the land has been steadily cultivated, maintained in an open condition, and ample plant food given, the soil remains fertile. Soils in the vicinity of rivers may need reclamation. 
Peat.-Peat is a very infertile type of soil, but by treatment with lime and basic slag, very fine results may be obtained. Where a soil merely has a thin layer of partly peat-like turf, mechanical breaking up of the surface will often effect a remarkable improvement. Heavy dressings of gas lime have also proved beneficial for such purposes, but where the peat is fairly deep, continuous work is necessary to reclaim it. Peat lands are often very wet, and require some system of drainage. Experience in Ireland has shown that these soils are not so hopeless as they were once thought to be. Dressings of potash manures are also very commonly required for this type of land. In some cases the process of paring and burning may be employed on peat lands. This is very drastic, and wasteful, but is sometimes the most easily managed. The rab cultivation of the Western Ghats belongs to this type. On many of the fen districts the application of marl, that is, chalky clay, has been found to be very beneficial, since it supplies lime in quantity, and potash in small amounts. On peat lands liberal manuring with common manures is almost always essential, since the peat contains little of any value to the plant. It has, however, always an ample capacity for absorbing water, and its physical properties are, therefore, not excessively bad. Occasionally peat may be found already mixed with lime. On such soils super-phosphate will generally give a better result than basic slag. Whenever lime is applied to soil for the purpose of reclaiming it, it is desirable that the lime should contain only a moderate portion of magnesia, since when the percentage of magnesia exceeds the percentage of lime, magnesia is harmful.

Reclamation.-There are considerable areas of land which are only producing very poor pasture, which can comparatively easily be made to produce far better feeding for stock. These areas occur in all parts of the world, but in well-populated districts there is little excuse for their existence. There are very large areas of land which have merely been neglected, and which are occupied by poor pasture. The boulder clay of the northern part of Eingland,

D. 
as well as other lands in other parts, can be immensely improved by dressings of basic slag, at the average rate of one or two hundredweight of slag per acre per annum. Such treatment encourages the growth of clover, and in the course of a few years completely alters the physical and chemical properties of the soil. Many uplands, where there is much heather and moor, can also, by a dressing of slag, and possibly lime, effect a steady improvement on the value of the land by enclosure and stocking with cattle. Even some soils on chalk have been reclaimed in a wonderful way by these means. Poverty Bottom, the property of Professor Somerville, is a case where neglected land on chalk has been immensely improved by the use of basic slag. Some of the lighter soils which are growing very indifferent pasture may be made to do much better by the application of potash, but, as a rule, the lighter land should not be down to grass, but should be ploughed, unless there is some specific difficulty, coming under the heading of the wet lands alluded to above. The reclamation of this type of land ultimately involves considerable amount of capital. The amount of money necessary to spend in a substantial dressing of basic slag, probably assisted by lime, is one which the farmer is often afraid of, but by spreading it out over several years the amount of money expended is not so severely felt. The difference between a barren field and a fertile field is very often more a matter of history than geology. Persistent efforts to cultivate a piece of land and make it fertile are rarely altogether unfruitful. Whether the result justifies the expenditure of labour is, of course, a different matter, since it is impossible to equate these two by the same method in different epochs. The labour that would otherwise have been wasted is not capable of being put down by any system of accountancy. The gradual improvement of the land by this type of utilization of spare moments is one of the most important results of giving ownership of land to the actual occupier. The man who hopes to get results many years hence from his spare moments is only the man who thinks he is likely to be on the spot for a long time. To attempt 
to reclaim many types of land on an industrial system is very often unpromising, as the capital necessary to be sunk is too large in proportion to the returns. The whole question of reclaiming land is of little value without considering some system of experiment. The mere fact that a piece of land is not doing well suggests the idea that probably somebody has failed to do better, and that the case is, therefore, not a simple one; but it need not necessarily be very complicated, and a simple type of experiment will not infrequently solve the riddle as to its failure. A soil is so variable that if any knowledge is required within a reasonable time, it is necessary to conduct all experiments in duplicate. It is not necessary that the piece of land under experiment should be very large. The most important consideration is that the person responsible for the experiment should have a sound knowledge of the process of conducting experiments, and a clear idea of the errors of practical experiment under practical conditions. The chief type of such experiment would be to lay out plots, of which there were two or three plots containing no manure and no improving treatment at all, two or three with phosphates, two or three with potash, two or three with nitrogen, and two or three with lime. Previous experience of that type of land would avoid many unnecessary experiments, since at least some things might be assumed fairly well beforehand, but soils differ so much, and the causes of fertility and infertility are so many, that it does not do to assume too much from a text-book. Roughly speaking, the errors of experiment on a growing crop on a piece of land will be about ro per cent. of the yield. For the purpose of the reclamation of barren land this is not at all a serious error, since unless the land is going to double its capacity it is hardly likely to pay any very heavy returns for big initial expense. The difficulties are, therefore, not as great as they are on an experimental farm. As the reclamation of land is generally a matter of a fairly big scale, it would be especially foolish to neglect a few preliminary experiments before proceeding to effect some system of reclamation. It is, of course, highly desirable that the materials used for 
the experiments should have a fairly accurately known composition, as otherwise much of the labour will be thrown away. A useful type of experiment would be, one plot of lime, a second plot basic slag, a third plot with sulphate of ammonia, a fourth plot with potash manure, and a fifth plot with no manure at all. These might be all crossdressed with other manures, or even with the same manures applied over again. If the same manures are applied over again in the cross-dressing as in the first dressing, one will get, of course, a double dressing in one case, and a compound dressing in another, but each case will have to depend upon its own merits. The term "reclamation of land" is sometimes restricted to warping. The process of warping consists in flooding and silting up swamps. Where hill streams or tidal estuaries exist, the low-lying land can be flooded from time to time, and a large quantity of silt deposited. Such silt is very fertile. No general principles can be dictated on this subject, it is a question of management.

\section{REFERENCES TO SECTION III}

Leather, "Memoirs of the Department of Agriculture in India," June, 191 7. "The Pot-Culture House," p. 43. (Thacker, Spink and Co., Calcutta.)

Hilgard, "Soils," pp. 399 and 422. (Macmillan.)

McConnell, "Agricultural Note Book," p. 8I. (Crosby Lockwood.)

Gorham, "Reclaiming the Waste," pp. I18, I42. (Country Life.)

Stokes, "Some Cases of Infertility in Peaty Soils," Journ. Board Agriculture, I913-14, p. 672 . p. $68 \mathrm{I}$.

"The Reclamation of Waste Land," Journ. Board Agriculture, 1914-15,

Howard, "The Irrigation of Alluvial Soils," Agric. Journ. Ind., I9I7, p. 185 .

Carey and Oliver, "Tidal Lands." (Blackie.) 


\section{PART III.-THE CROPS}

\section{SECTION I.-PHOTO-SYNTHESIS}

THE natural absorption of solar energy by plants is a process called photo-synthesis, to account for which there are many theories, none of which can be considered as proven. Some outstanding features, however, remain without any question. The sun's rays falling upon green leaves are absorbed with the utilization of energy for the production of plant materials. The proportion of energy used in this way is small, as is shown in the following table :-

\section{TABLE I 8.-Percentage of Total Solar Energy FALIING ON A LEAF.}

\begin{tabular}{|c|c|c|c|c|}
\hline \multirow{2}{*}{$\begin{array}{l}\text { Energy used in assimilation } \\
\text { Energy used in evaporation of water } \\
\text { Energy transmitted }\end{array}$} & & & \multicolumn{2}{|c|}{0.66 per cent. } \\
\hline & & & $48 \cdot 39$ & ", \\
\hline Energy transmitted $\quad \ldots \quad$.. & & .. & $3 I^{*} 40$ & $"$ \\
\hline nergy radiated, convected, & & .. & 19.55 & 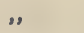 \\
\hline
\end{tabular}

This table shows that the amount of energy actually utilized for assimilation of carbon dioxide and its conversion into organic plant matter is comparatively small, and that a very great deal of the energy is used merely in evaporating water (see p. rro). Carbon dioxide is absorbed by the leaf with very great readiness, in spite of the small proportion or carbon dioxide in the atmosphere. It is often assumed that one of the first products is formaldehyde. That formaldehyde can polymerize to sugars is undoubtedly well proved. The mechanism by which formaldehyde can be produced in the plant is more difficult to discover. Oxygen appears to be evolved practically simultaneously with the absorption of carbon dioxide, and therefore very elaborate chemical changes seem improbable. The energy that will 
be freed by the combustion of dry plant materials equals the amount of solar energy necessary for their production, and the animal energy obtained by consuming plant products will also be the same amount less some forms of waste (discussed in Part IV.). Although the actual mechanism by means of which carbon dioxide is converted into complex organic bodies is only very little known, the substances themselves have been the subject of much elaborate inquiry. The following table gives, in brief form, the chief classes of substances which are produced in plants by these means.

TABLE I9.

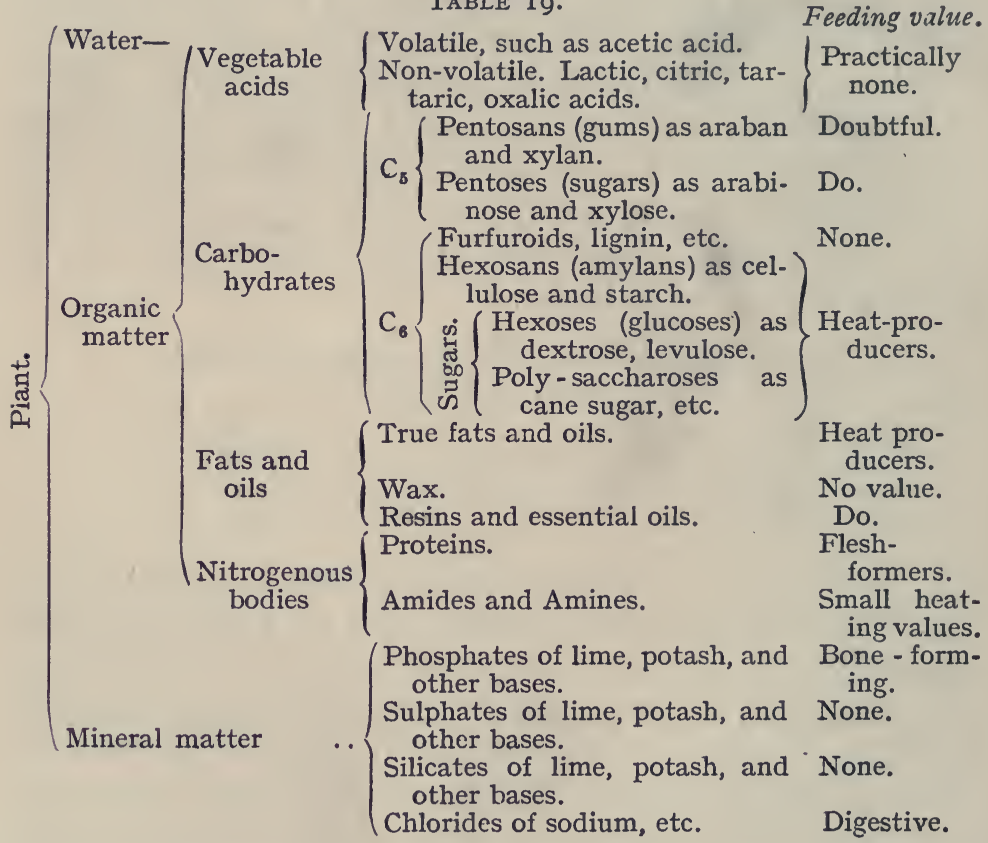

In some cases they are very well-known organic substances, in others they are substances only described in the advanced text-books.

The Vegetable ACIDS.

Formic Acid, H.COOH, occurs in small quantities in stings of nettles, in butter exposed to sunlight, in the contents of the stomach, and in many fermented materials. Formic 
acid is a strong volatile acid, of pungent smell, and very irritating in contact with scratches on the skin.

Acetic Acid, $\mathrm{CH}_{3} \cdot \mathrm{COOH}$, occurs in many plants, is a common product of fermentation, and is produced in the distillation of wood (see p. I29), from which latter source most of the acid of commerce is obtained. It can be produced from coniferous sawdust, saturated with sodium hydroxide, and subjected to steam and air at $120^{\circ}$ Cent. It is a mono-basic acid, volatile, has a fairly strong smell, and forms well-recognized salts, mostly soluble in water. The purer acid is used for pickles and other food purposes. Calcium acetate is used for the manufacture of acetone, and for mordanting cotton goods.

Lactic Acid, or hydroxy propionic acid, $\mathrm{CH}_{3}$. $\mathrm{CH}(\mathrm{OH})$.$\mathrm{COOH}$, is a common product of fermentation, and is also found in muscular tissue. It can be manufactured from glucose, chalk, and sour milk. It is not volatile, but on concentration the solution forms a lactone by loss of water. This ability to split off water makes it a valuable hydrolytic agent. In free and uncontrolled fermentation the development of lactic acid proceeds best in the presence of much nitrogenous material. The salts of lactic acid crystallize poorly.

Oxalic Acid, $(\mathrm{COOH})_{2} \cdot 2 \mathrm{H}_{2} \mathrm{O}$. - The oxidation of almost any organic substance will produce some oxalic acid. It is almost universally found in plants, but beet leaves, rhubarb leaves, and sorrel contain especially large quantities. Oxalic acid is manufactured from coniferous sawdust, saturated with sodium hydroxide, subjected to steam, and a large proportion of air, at $300^{\circ}$ Cent. The sodium oxalate so formed is treated with sulphuric acid. It is a di-basic acid, non-volatile, forms good crystalline salts with the alkalies, whilst its calcium salt is marked by its special insolubility, a property which enables plants to deposit insoluble calcium oxalate in their tissues as a means of getting rid of excessive quantities of this acid. Calcium oxalate is insoluble in any of the acids commonly found in plants. Oxalic acid is poisonous to both plants and animals. 
It is very easily oxidized in the laboratory, and becomes oxidized in the soil by bacterial action. In the presence of an excess of alkaline oxalates the heavy metals, like iron and copper, produce double salts with the alkalies, which are soluble.

The homologues of oxalic acid are also important. A member of the series, malonic acid, $\mathrm{HOOC} \cdot \mathrm{CH}_{2} \mathrm{COOH}$, has no great interest for present purposes, but succinic acid is present in many plants, and is produced during fermentation, whilst its oxidized products are met with in still larger amounts.

Malic Acid, or Hydroxy Succinic Acid, $\mathrm{HOOC} . \mathrm{CH}_{2}$-$\mathrm{CH}(\mathrm{OH}) \cdot \mathrm{COOH}$, occurs in apples, gooseberries, cider, and many other fruit materials.

Tartaric Acid, Dihydroxy Succinic Acid, HOOC.$\mathrm{CH}(\mathrm{OH}) \cdot \mathrm{CH}(\mathrm{OH}) \cdot \mathrm{COOH}$, is found in considerable quantities in grapes and wine. The deposits in wine casks, known as argol, is one of the chief sources of tartaric acid. Argol, purified by crystallization, is known as tartar, or cream of tartar. The purified argol is treated with calcium carbonate and calcium sulphate to obtain a precipitate of calcium tartrate, which is subsequently decomposed by sulphuric acid. The recovered calcium sulphate supplies all that is necessary for the former part of the process. Tartaric acid is non-volatile ; crystallizes well ; is easily decomposed by heat, giving off a smell of burnt sugar; forms soluble salts with the alkalies; insoluble salts with the alkaline earths; complex ions with iron and copper; and produces a potassium hydrogen tartrate which is insoluble in water, though soluble with decomposition in either acids or alkalies. Tartaric acid is used medicinally, for summer drinks, for photography, for silvering mirrors, for bleaching, and for dyeing.

Citric Acid, HOOC. $\mathrm{CH}_{2} \cdot \mathrm{C}(\mathrm{OH})(\mathrm{COOH}) \cdot \mathrm{CH}_{2} \cdot \mathrm{COOH}+$ $\mathrm{H}_{2} \mathrm{O}$, is a very common plant acid. Lemons can produce as much as five or six per cent., and Dyer found that most plant roots contained acids, largely citric acid, up to about I per cent. Lemon juice is boiled with calcium carbonate 
till nearly, but not quite, netitral, and the calcium citrate formed acidified with sulphuric acid. Citric acid forms an insoluble calcium salt, which does not easily form without boiling. The deposition of calcium citrate by boiling milk in a saucepan is a well-known phenomenon, which produces a crust on the bottom of the saucepan, rather difficult to remove.

\section{THE CARBOHYDRATES.}

Fibre. - The members of the carbohydrate group, which are pentosans, $\mathrm{C}_{5} \mathrm{H}_{8} \mathrm{O}_{4}$, that is five carbon gums, are very common in all the fibrous parts of plants. Straw may contain up to 20 per cent. of this material, which is consequently often known under the name of straw gum. The amount of pentosan present in most plant products is roughly in proportion to the amount of fibre. No satisfactory use has been made of straw gum as yet, since its adhesive properties are too feeble. If the amount of wheat grown in Great Britain is to be doubled, the straw will also be doubled. It is hence important to discover new uses for straw, and this subject seems worthy of further inquiry. When heated with dilute acids the pentosans are first converted into pentoses, and then condense into furfuraldehyde, a volatile liquid which can be distilled with steam and forms many coloured compounds, some of which are dyestuffs. Straw is the best raw material for the production of furfuraldehyde. The pentoses themselves are not common materials in plant life. The pectins, gums, and such substances, frequently yield substances of both the $\mathrm{C}_{5}$ and $\mathrm{C}_{6}$ groups, and are, therefore, compound bodies containing these two groups (see p. I3I). The cellulose group is a very common material to find in plants, most of the stiffening parts of plants being due to this substance, which, in its pure form, approaches $\mathrm{C}_{6} \mathrm{H}_{10} \mathrm{O}_{5}$ in composition. Cotton-wool and filter paper (see p. I28) may be taken as practically pure specimens of cellulose. Cellulose is insoluble in all common reagents, but is soluble in solutions of copper hydroxide in ammonia, as well as in zinc chloride 
or sulphuric acid. Solutions of cellulose in cuprammonium hydroxide are used in making Willesden paper and canvas ; solutions in zinc chloride are used for electric carbon filaments; and solutions in sulphuric acid are used for parchment paper. Many of the fibrous parts of plants are not pure, but contain furfuroids, lignin, etc.

Starch, $\left(\mathrm{C}_{6} \mathrm{H}_{10} \mathrm{O}_{5}\right)$, or probably slightly more hydrated, is a very common form of storing reserves of plant foods in seeds, stems, bulbs, and other parts of a plant where they are not required at the time, but at some later stage of the plant growth. Starch is commonly recognized by its microscopic form and reaction with iodine. A microscope with Nicol prisms is of great use in observing starch grains. Dry heat above $I 50^{\circ}$ Cent. converts starch into dextrin. In the presence of water, starch grains burst when heated. Starch is soluble in hot water, forming a colloidal solution. Potato starch gelatinizes at $65^{\circ}$, but oat starch needs $95^{\circ}$ Cent. On the addition of a drop of copper sulphate to a solution of starch, followed by a large excess of sodium hydroxide, a blue precipitate is produced, which is not altered on boiling. The action of ferments, such as diastase, turns starch into soluble products, dextrin, malto-dextrin, maltose, etc. Further treatment with dilute, acid will convert these products into glucose (dextrose). Diastase is a typical enzyme, and has the power of converting I000 times its own weight of starch into soluble materials.

Dextrin, a body very similar to starch, is generally present in plants to a small extent, and can be obtained by heating starch either by itself or in presence of water or with traces of nitric acid. It differs from starch in giving a red colour with iodine. Dextrin is used in place of gum, especially in hot climates, as it is less hygroscopic than gum arabic. For small articles, like postage stamps, dextrin is superior to gum arabic, but for large articles its adhesive power is too small.

The Mono-Saccharoses, or Hexoses, $\mathrm{C}_{6} \mathrm{H}_{12} \mathrm{O}_{6}$.Glucose (dextrose, grape sugar) occurs in all the sweet-tasting plants, crystallizes with some difficulty, often with one molecule 
of water of crystallization. It is soluble in water, or alcohol, ferments rcadily, rotates the plane of polarized light to the right, and reduces Fehling's solution, or alkaline solutions containing copper and tartaric acid. Its properties are those of an aldo-hexose. Glucose is manufactured by boiling starch with dilute sulphuric acid, removing the acid with lime, and concentrating the liquor.

Fructose (lævulose, fruit sugar) is also found in plants, and differs from dextrose, since it is a keto-hexose. Honey consists of a mixture of glucose and fructose. In cold weather the glucose separates out as crystals, leaving the fructose as a liquid. Crystallization of fructose presents many difficulties, but the material can now be produced commercially in the solid form. Fructose reduces Fehling's solution, and rotates the plane of polarized light to the left.

Galactose, a sugar closely tesembling dextrose, is not generally found in plants, although it is a common result of the hydrolysis of many of the gums, where it occurs in combination with one of the pentoses. It is also a constituent of raffinose. Many forms of yeast do not ferment galactose.

The Di-Saccharoses, $\mathrm{C}_{12} \mathrm{H}_{22} \mathrm{O}_{11}$.-Maltose, the condensed product of two molecules of glucose, is contained in malt, and is produced from starch during the germination of barley grains. It is a product of the hydrolysis of starch, intermediate between dextrin and glucose. Maltose reduces Fehling's solutions both before and after hydrolysis, but is only fermented after hydrolysis.

Lactose (milk sugar) is the product of condensation of galactose and glucose. It occurs in cows' milk to the extent of between four or five per cent., and in human milk up to eight per cent., but has not been found in plants. It is made from whey, a cheese by-product, by crystallization, and is used largely in medicine.

Cane Sugar (sucrose) is the best known of the sugars, and is contained in sugar cane, sugar beet, and many other sources. Of the sugars we have dealt with above, this is the 
only one which does not reduce Fehling's solution (see p. I07).

The Tri-Saccharose (raffinose) is the condensed product of the three mono-saccharoses glucose, fructose, and galactose, and occurs in sugar beet. Its admixture with sucrose is neither easy to detect nor resolve. It does not reduce Fehling's solution, and has the high rotary power $[a]_{\mathrm{D}}=+104^{\circ}$.

The Tetra-Saccharose (stachyose) is the chief carbohydrate in the Japanese artichoke. It hydrolizes to glucose, fructose, and two molecules of galactose. It does not reduce Fehling's solution.

\section{The Fats and OILs.}

These are all compounds which have glycerine as a base, and one or more of the fatty acids for the acid part of the ester. Oils are obtained from seeds either by pressure or by "Rendering." The latter process consists in boiling the seeds with water, when the husks and fibre sink and the oil rises to the surface. With modern methods, extraction by solvents like petrol is employed. The acids universally found are stearic $\left(\mathrm{C}_{18} \mathrm{H}_{36} \mathrm{O}_{2}\right)$, oleic $\left(\mathrm{C}_{18} \mathrm{H}_{34} \mathrm{O}_{2}\right)$, and palmitic $\left(\mathrm{C}_{16} \mathrm{H}_{32} \mathrm{O}_{2}\right)$. Other special acids in smaller amount are specific to particular plant products. All the fats, on treatment with alkali, are hydrolized with the production of soap and glycerine. Glycerine is miscible with water, and is non-volatile, although it can be distilled in a vacuum. The fatty acids, when unsaturated, absorb iodine from solution, and the iodine absorption is closely connected with the drying properties of the oil. Sulphur chloride acts on fats rapidly. Both sulphur and chlorine are taken into the molecule. These compounds are used as rubber substitutes (see p. I65). Free sulphur also acts upon the unsaturated oils at temperatures above $120^{\circ}$ Cent.

Some other materials, which are extracted by ether in the ordinary analysis, do not belong to the true fats and oils. These are waxes, which are often compounds of the higher alcohols, and higher acids. Whilst the fats and oils have a very high feeding value, the waxes have no value as food. 
Essential oils are the volatile constituents found in plants. Turpentine oil is one of the most important.

\section{THE NITROGENOUS BODIES.}

The nitrates are absorbed by plants, and are subsequently converted into organic nitrogen compounds. In cases of drought, plants can store nitrates in their stems. All the ordinary nitrates are soluble in water. Ammonia salts are only found in traces in plants. Plants, indeed, cannot endure any considerable quantities of ammonia, free or combined (see p. I4).

Ammonia salts in organic materials can be distilled out with precipitated chalk.

Amides, Amines, etc.-Miscellaneous non-albuminoid nitrogenous bodies in plants are often called amides. A portion of these are true amides, but some are not. Asparagine, for example, is both an amide and an amino acid, which on distillation with moderately strong alkali will yield half its nitrogen as ammonia. Alkaloids, nitrogenous glucosides and amines, are also present.

The Albuminoids, or the Proteins, are the complex bodies of which the amino acids are the basis. They can be precipitated by copper hydrate, lead acetate, uranium acetate, or other precipitants, the non-albuminoid nitrogenous matter remaining in solution. For a rough division the nitrogen insoluble in lead acetate solution may be considered protein nitrogen. The ammonia distilled by potash, but not distilled by calcium carbonate, can be considered as amide nitrogen. The nitrogen distilled by calcium carbonate can be considered as ammonia compounds, and the nitrates precipitated by nitron can be taken as the nitrate nitrogen. It will not infrequently be found in roots and leaves that the sum of these fractions of nitrogen will not add up to the total nitrogen, but in the case of grains, seeds, hay and straw, the above division will not give any appreciable surplus or deficiency. Roughly speaking, one may say that mature plants do not contain any large quantities of nitrogen outside 
the groups alluded to, but immature plants will often have some nitrogen in unknown combinations.

For the production of proteins in the plants it is necessary to supply nitrogen, phosphorus, and sulphur. The other plant products which do not contain those elements, are indirectly dependent upon the proteins, and the production of full quantities of starch or sugar cannot be obtained without adequate supplies of fertilizing ingredients containing those elements.

The waste of solar energy alluded to in Table I8 shows that much of the energy of the sun is expended in evaporating water. Experiments, both on the small and on the large scale, show that the proper utilization of fertilizers results in economy in use of water (see p. IOI). Phosphates and nitrates appear to be particularly valuable in this respect. The use of top dressings of nitrate of soda or sulphate of ammonia during the droughty periods on corn and hay crops is a very well-known practice, whilst the use of phosphatic manures, either directly or indirectly, during the stimulus of root development also produces an economy of water. The question of the water supply to the plant is, therefore, very closely bound up with the supply of proper fertilizing ingredients, and much can be done in dry regions or during dry periods to economize the water supply by a liberal use of phosphatic and nitrogenous fertilizers.

\section{REFERENCES TO SECTION I}

Haas and Hill, "Chemistry of Plant Products," p. I43. (Longmans.)

Fenton, Journ. Chem. Soc., I907, T. p. 687.

Borday, Proc. Roy. Soc., I874, p. I7x.

Warner, Proc. Roy. Soc., I9I4, B. 87, p. 378.

Dyer, Journ. Chem. Soc., I 894, T. I I 5 .

Cross and Beavan, "Cellulose." (Longmans \& Co.)

Forster, " Bacterial and Enzyme Chemistry." (Arnold.)

Armstrong, "The Simple Carbohydrates ; Monograph on Bio-chemistry." (Longmans.)

Rideal, "Practical Organic Chemistry." (Lewis.)

Barnes, "The After Ripening of Cane," Agric. Journ. Ind., I9I7, p. 200.

Bayliss, "The Nature of Enzyme Action." (Longmans.)

Jorgensen and Stiles, "Carbon Assimilation." (Wesley.) 


\section{SECTION II.-THE CARBOHYDRATES PRODUCED IN CROPS}

(a) Sugar.-Of the various sugars given in Section I., the di-sacchacrose named sucrose, or cane sugar, is by far the most important. Cane sugar is present in many plants, and is extracted from many different sources. Of these, the sugar cane is the best known, and oldest worked. Sugar cane is grown chiefly in warm climates, such as the Southern United States, the West Indies, Queensland, the Philippines, and India. The sugar cane grows best in a good, deep soil, generally of a dark colour. It is propagated from sets in a manner somewhat resembling potato planting; that is, sets containing two or three buds are planted a few inches below the surface, in a well-manured soil. In some places entire canes are planted, but this tends to produce an irregular crop. Irrigation equal to 50 inches of rain is always necessary, unless the rainfall is exceptionally heavy. The crop lasts about twelve months, and there is some difficulty in determining when it is ripe. Where irrigated water is difficult to obtain, mulches are not infrequently used on the surface. In Mauritius the cane is often planted in pits. Very frequently the crop is grown for two or three years in succession, since after the first crop has been cut the old stem tillers freely, and produces what is called a ratoon crop, which is, however, never equal to the first year's growth. As in all tall crops, "lodging" is a serious cause of loss. The side leaves have to be removed during the process of cultivation. Some system of rotation is nearly always necessary, so that the cane is not cultivated on the same land more than once in five or six years. The cane is subject to all kinds of pests. An interesting method for protection 
against pests adopted in India is to put castor cake and salt into the water, when the poisonous compounds of the castor dissolve in the salt water, and destroy many pests. When the crop is ripe, which takes about twelve months from

Table 20.--Indian Sugar.

Composition of Sugar Canes.

\begin{tabular}{|c|c|c|c|c|c|c|}
\hline & & & & & Thin cane. & Thick cane. \\
\hline Fibre & 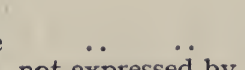 & & & - & $\begin{array}{c}\text { per cent. } \\
\text { I } 5\end{array}$ & $\begin{array}{c}\text { per cent. } \\
8 \frac{1}{2}\end{array}$ \\
\hline Juice, & , not expressed by & Bulloc & k Mill (Water) & . & 35 & $16 \frac{1}{2}$ \\
\hline Juice & expressed (Water) & $\ldots "$ & $\begin{array}{c}., \quad \text { (Sugar) } \\
. . \\
.\end{array}$ & $\begin{array}{l}. \\
.\end{array}$ & $\begin{array}{r}5 \\
39\end{array}$ & $\begin{array}{r}3 \\
61\end{array}$ \\
\hline " & ., (Sugar) & . & .. & . & 6 & II \\
\hline
\end{tabular}

Table 21.-Sugar Cane, Indian, 200-300 Acre Production. Cost of Cultivation in Rupees per Statute Acre.

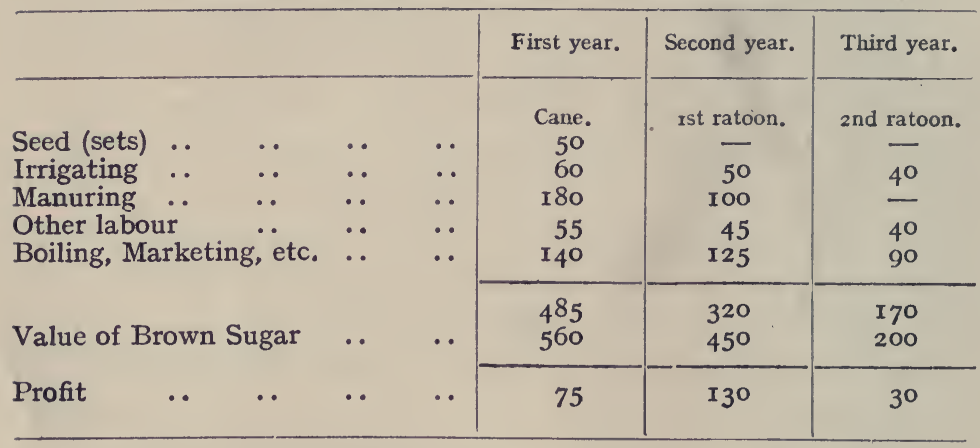

planting, the cane is usually cut with some kind of sickle, and removed to the mills. When cane is cultivated in primitive fashion, as is the case in India, the mills containing three rollers are semi-portable and are worked by four bullocks. Two of the rollers are about half an inch apart, and the third roller is only one-eighth of an inch from the centre roller. By passing the cane through the wide gap first, and then through the narrow gap, a double squeeze is given, and about 80 per cent. of the juice extracted. In the West Indies, the United States of America, and Queensland, with more efficient machinery, and by moistening the pressed 
cane with a little water, as much as 90 per cent. of the juice can be extracted. Excepting under the most primitive conditions, lime is always used for removing many of the impurities in the juice. In the field methods of manufacture, adopted in India, the lime is added until the natural colour of the sugar cane juice, which acts as an indicator, shows that neutrality has been reached. The liquid is then boiled down, and very carefully skimmed. In more elaborate and carefully industrialized systems a slight excess of lime is used, then filtered, the excessive lime removed, by carbonic acid, and again filtered. Some of the proteins are precipitated on boiling in any case. In primitive systems the whole material purified by skimming is boiled down until it becomes very thick, when it is poured into moulds. The moulds often consist of holes in the ground, lined with cloth, so that some portion of the molasses drains away. In such a case a brown sugar is obtained. Where it is desirable to get a very white sugar the boiling-down process takes place in a vacuum pan. Sugar is converted into caramel, a brown colouring matter, by the action of heat, but by reducing the pressure, and therefore the boiling point, the heat is lowered to less than the temperature at which sugar begins to caramelize. Further improvement can be adopted by separating the molasses from the sugar by a centrifugal machine. A small centrifugal machine, worked by hand, can be obtained for field use. In India, brown sugar is preferred to white sugar, and hence little effort is made to carry the purification to any extent. The supply of fuel is always an important point in the manufacture. The waste cane, if dried, makes a useful fuel, and the dricd side leaves, unless required for fodder, can also be used as fuel. In India the upper leaves are used to feed the bullocks. For the satisfactory cultivation of sugar cane nitrogenous fertilizers are essential, and in experimental work conducted in India quantities of from two to five hundred pounds per acre of nitrogen have been used, although the larger quantity seems unnecessary. Other manures, such as phosphatic and potassic ones, are sometimes necessary, but not to anything

D. 
like the extent that nitrogenous ones are. It appears to be necessary that the nitrogen should always be in much larger proportion than the other fertilizing ingredients. Indeed, where this has not been the case, individual observers have not infrequently reported that phosphates have done harm, but that is only a particular case of the importance of preserving a proper balance of fertilizers, which has so often been alluded to. In experimental results obtained under good conditions in India quantities amounting to nearly five tons of crude sugar per acre have been obtained. At the larger industrialized concerns in the United States about Io or I2 per cent. of the weight of cane is obtained as sugar. In vegetarian countries sugar replaces the meat of meat-consuming countries, and the amount produced on the small scale is in excess of anything recorded in ordinary Government statistics. Considerable quantities of softer canes are never made into sugar at all, but are eaten as they are.

Sugar Beet. - In temperate climates the sugar cane does not ripen satisfactorily, and sugar is therefore prepared mostly from the sugar beet. Sugar beet is a crop which closely resembles the mangel wurzel in its properties. An enormous amount has been written upon this subject, and there is no particular reason why the sugar beet should not be cultivated in many parts of the British Isles. Sugar beet can certainly be grown in the north of England, as well as in the south, but if grown will replace some of the other crops. Whether that will be a profitable arrangement only the future can tell. The manufacture of sugar from sugar beet follows a somewhat different course to that of the sugar cane. The system adopted is called the diffusion process. In the process the sugar beet is cut into slices, extracted with water (at $85^{\circ}-90^{\circ}$ Cent.), and the weak solution obtained used to make a stronger solution by extracting more beet. The concentration of the sugar liquors rises until it becomes approximate to the strength of the juice in the beet themselves, that is to say, it rises to nearly I8 per cent. of sugar. This process has the great advantage that the cell-wall of 
the beet itself is used as the filter and purifier. The albuminoids and the gums do not diffuse through the cellwall as readily as the sugar, and therefore the sugar solution obtained is in a much purer condition than that obtained from the sugar cane. The other substances present in raw cane sugar are pleasant to the taste, and probably most people prefer the flavour of brown sugar to white when it is made from cane. It is rather the appearance of white cane sugar that gives it a high value. The impurities in sugar beet include substances which are bitter to the tongue and musty smelling to the nose, and the purification does not entirely remove these impurities, though they are too small in amount to estimate. The general process of purification is much the same as in the case of cane. Where the resulting beet slices extracted can be used as cattle food it may easily be more profitable not to attempt to remove the last trace of sugar, but to leave a little in for the cattle food. The cultivation of sugar beet accommodates itself well to the ordinary types of mixed agriculture adopted in temperate climates, especially where the production of milk and meat form an essential part of agriculture. This is an undoubted advantage which the sugar beet possesses over the sugar cane, inasmuch as the sugar cane gives no useful by-product and does not lend itself so well to the working of the general agricultural plan.

About eleven tons of clean beet per acre represent the European average production, with about I 6 per cent. of sugar obtainable from them, or, say, roughly two tons of sugar per acre. This is much below the best production of cane sugar, but it is very difficult to get average figures of the production of cane sugar, since there are such large amounts grown in a very primitive manner. Experience is, however, showing that no nation can afford to be entirely dependent upon outside sources, and at least some fraction of the necessary sugar may have to be grown in Great Britain, even if it is not economically profitable. The other parts of the British Empire are more nearly self-supporting as regards sugar. 
The Date Palm is also one of the minor sources of sugar. Most species of the palm can be used for the production of sugar; many of them are used for the production of sugar for fermentive processes. When it is desired to manufacture sugar the palm is cut, and the sugar juice runs into a pot. The pots are collected, and the juice quickly boiled down before fermentation takes place. With the aid of a hand centrifugal machine very pure sugar can be obtained in a simple manner. The quantity made is, however, small, and can never compete commercially with the other sources of sugar.

Sugar Refining.-Most of the sugar industry in the British Isles in the past has rather turned on the purification of crude sugars produced elsewhere. Many reasons have been given for the collapse of the sugar purification industry in the British Isles. If reference be made to an old work by Higgins, dated I797 (see Bibliography), the following will be found: "It is now well-known that an artist with a very little education will soon learn all that is useful to him in mechanics and chemistry." If such opinions were generally held, the collapse of the industry is readily understood.

Turnips, etc.-A very large amount of sugar is produced and consumed in the form of swedes, turnips, and mangolds. These crops form the essential part of a rotation, and permit the cleaning of the land. Good seed beds and liberal manuring are essential, and the land is usually worked into ridges. Super-phosphate, sulphate of ammonia, and potash salts are all used as well as farmyard manure. For mangolds, salt is needed as well. The seed is generally used somewhat generously, the young plants being " singled," that is to say, all those that are not needed are hoed out. In the United Kingdom, about twenty-four million tons of turnips and swedes are grown. The swede crop in the northern counties contains about 6 per cent. of sugar, on the average a little more. The average for the whole country is probably slightly less, and the white turnips will be distinctly lower, but it is probably not seriously wrong if 
we say that there is about 5 per cent. of sugar in those twentyfour millions of tons; that is to say, there is well over a million tons of sugar grown in the British Isles and eaten chicfly by cattle in the form of turnips and swedes. In addition to that, there are about ten millions of tons of mangolds grown, which, on the average, will have a rather higher percentage of sugar. Taking all together, there cannot be much less than one and a half millions of tons of sugar produced in the British Isles and consumed in this way, or, roughly, one-tenth of the world's production of cane and beet sugar. In the case of the mangold, much of the sugar is cane sugar, in the case of turnips and swedes much of it is glucose. The crops of swedes, turnips, and mangolds all present some points of similarity, requiring good manuring and a fairly deep soil. All of these sources of sugar could be used for fermentive purposes for the production of alcohol if the necessity arose. During the war, an increased fraction has been used directly as human food. Some fraction might be used for the manufacture of jam. No doubt a mixture of swede turnip pulp and fruit boiled down would not be a first-class jam, but it would be better than letting the fruit waste. Unfortunately, turnips do not ripen till after most of the fruit is over, but some of the later fruits might be used. Sugar beet will keep well, and could be held over the winter, when it might be used for the preservation of early summer truits. Sugar beet can be dried easily, and ground in the mill to powder, when a crude sugar results. As war measures, such schemes are worth a trial.

(b) Starch.-Starch is chiefly produced in cereal crops, although it is a common ingredient of many forms of plant life. Excepting in some of the oil seeds, it may be found in any of the finished forms of plant life, and is one of the food reserves of the plant. The methods of preparing starch are almost independent of its origin. The systems chiefly employed are-

(I) The fermentation process, in which the material, after being ground up with water, is allowed to ferment. The fermentation results in the solution of the albuminous 
part, and the liquor is then run off, leaving the starch as a deposit. After washing once or twice, the starch is left. This method is rather wasteful, as it is not easy to get more than 30 per cent. of any of the grains in the form of starch.

(2) Alternative methods consist in macerating the raw material with water, and passing through a fine sieve, containing about two hundred meshes to the linear inch. The glutinous parts remain on the sieve, while the fine grains pass through in the water. The muddy starch liquor is then allowed to settle, and the liquor is poured off, and the starch dried. Combinations of these processes are not infrequently used, in which a certain amount of fermentation is permitted, and some kind of sieving method is employed. In more modern systems it is not uncommon to employ sodium hydrate and sulphurous acid as convenient means of dissolving the proteins and obtaining a purer starch. Starch must either be dried without any heat, or a very low degree of heat must be maintained, otherwise the starch becomes gelatinized. Potato starch gelatinizes readily, but rice starch with difficulty. The large starch grains gelatinize most readily. Air-dried starch will usually contain about 20 per cent. of water, and that dried with a moderate degree of heat contains only Io per cent. The starch consists of very small grains, which are recognized under the microscope by their characteristic form and size. Potato starch grains are large and rice starch grains small.

Wheat. - Wheat constitutes one of the most important of the cereals which contain a high percentage of starch. Wheat is grown in almost all parts of the world, best on a fairly heavy soil, and in a climate which is neither very damp nor very dry. Arid regions can, however, with the aid of irrigation, produce very fine wheat crops. The introduction of irrigation into the Punjab, in India, has resulted in converting some almost useless land into very excellent wheat country and the growth of wheat in Egypt is dependent on irrigation. Wheat is, of all the crops, the one which can be cultivated for the longest period of time on 
the same land without change, but the best yields are obtained on virgin lands, or under systems of mixed farming with rotation. The yields per acre in the British Isles, and in Canada, are generally about 30 bushels, but the yield in some other parts of the world does not amount to more than about one-quarter of that figure (see p. 206). The use of nitrogenous manures for wheat is important. The desirability of top dressing with such a manure as sulphate of ammonia has been alluded to in Part I., Section I. As a rule, wheat is not used for the industrial manufacture of starch, because wheat commands too high a price.

Maize. - Three-quarters of the world's supply of maize is grown in North America, but the advantages of maize are gradually becoming more and more recognized in the warmer parts of the globe. It is better suited to higher temperatures than wheat, and though much benefited by a sufficient rainfall, is capable of developing in drier situations than wheat. The actual amount of maize yielded is, howeve1, not dissimilar to that of wheat, and in mediumly warm districts the two cereals compete with one another. In cooler climates maize does not ripen satisfactorily, though the crop is often used as green fodder. The growth of maize is very rapid, four months being not infrequently sufficient. As a rule, it is best grown under some system of rotation, needs fairly deep and thorough cultivation, and is improved by fair dressings of farmyard manure, lime, phosphates, potash, and sulphate of ammonia. On the large scale it is often planted in heaps three or four feet apart, so as to allow of cultivation in between. The plant grows from about five to twelve feet high. Much of the crop is fed to stock, a large fraction husked in the field and sold for manufacturing purposes. Maize is admirably suited for the manufacture of starch, and in the United States of America forms the chief source of all forms of that article. The composition of maize is very constant at about 70 per cent. carbohydrates, mostly starch, and about 4 to 5 per cent. oil. Maize germ meal, the germ after extracting the oil, is used as cattle food. Gluten 
feed meal, the residue from starch factories, is used for cattle food, and is rich in albuminoids.

Rice.-Rice is a cereal particularly suited to wet situations: It is grown chiefly in Bengal and Burmah, but is also sown in Japan and China. The number of varieties of rice seems almost unending. In India there are several different groups of varieties which belong to the seasons. The winter rice is generally sown in May or June, the autumn rice is usually sown in August, the summer rice in January or February. The growth of the crop is extremely varied, according to the type of cultivation, some of the very rapid varieties being able to grow in about two months, and some of the very slow ones taking the best part of a year. On the average, however, two crops are obtained in the year. The best type of soil is a sandy one, lying upon clay, where the irrigating water can be flooded, held up by the subsoil, and yet leave the surface soil sufficiently open for the growth of the plant. With very wet varieties the depth of water may be so great on the fields that the workers actually use boats to transport them over the field; but in the hill regions, where the slopes are often terraced, only an inch or so of water is used for irrigating purposes. Rice is best sown in a seed bed and transplanted. Not infrequently the ploughing operations are carried out under water, so that the bullocks have to wade through to do their work. On those lands that permit of such treatment, where the growth of the rice is excessive, the young rice is grazed by cattle, in a similar way to wheat being grazed by sheep in temperate climates. There are no less than about seventy millions of acres of rice in India. The rice, as separated by threshing, contains a large amount of husks, and in this form is commonly called paddy, the term rice being retained for the finished product after husking. The term "paddy" is frequently employed with reference to the whole system of cultivation, and the terms "paddy fields" and "paddy bird" are more commonly in use in the east than the term " rice," which chiefly refers to the finished article ready for the table. In the countries where rice is grown, the terms " paddy " and 
"rice" are used in the same way as sheep and mutton are used in England. The rice kernel is enclosed in a very hard husk, which requires considerable amount of work over its separation. On a small scale rice is pounded by hand as the recognized work of the women of India. On the large scale in Burmese mills rice is decorticated by machinery. The liusks so removed are quite worthless, but the resulting grain is very frequently polished still further to produce white rice. The resulting white rice is much less nutritious than the streaked brown rice, which contains the bran adhering to it. White polished rice kernels are very nearly pure starch, whilst rice bran contains most of the oil and albuminoids of the grain. The following table represents the varying composition of the different parts of the rice plant:-

TABLE 22.

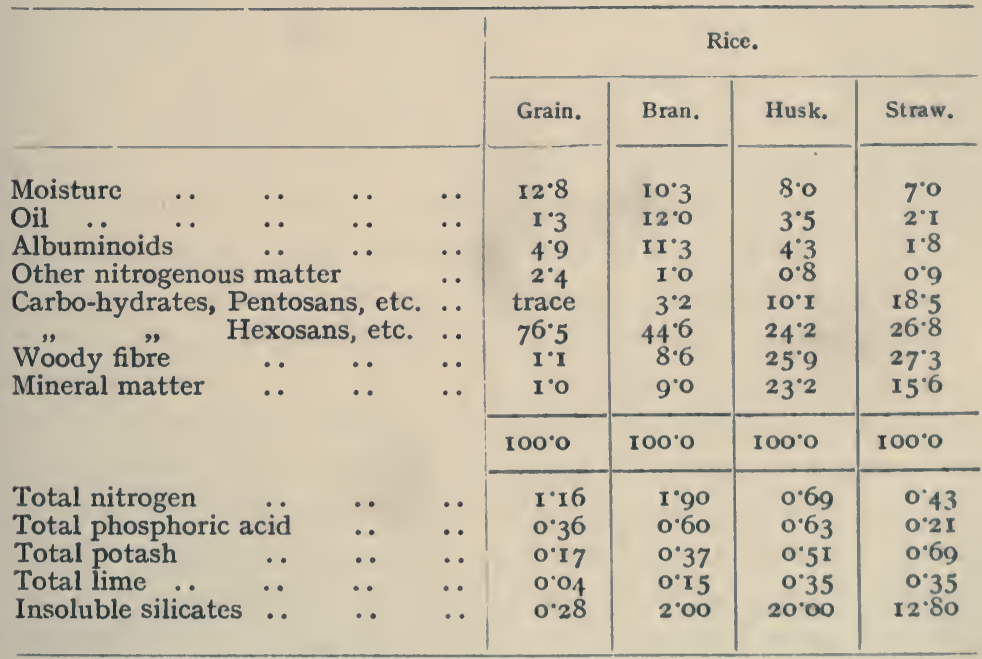

Rice may, when merely ground into a powder, scrve the purpose of starch, or the starch may be prepared from rice by the usual methods (see p. II7). Both maize and rice lend themselves to the possibility of producing starch by the dry method of grinding and blowing by currents of air, but starch is chicfly made by one of the wet methods. 
Potatoes. - The potato, although well known and popular to-day, is a very recent introduction into general use. It is cultivated entirely from the tuber itself, and not from the seed of the plant. The true seed of the plant produced from the flowers does not yield usable potatoes for two or three years, after which time new varieties of potatoes are obtained and have often fetched extravagant prices. The old varieties, in process of time, tend to die out. From the strictly botanical point of view, it must be remembered that all the potatoes of one kind in the world are really one single plant. They have all come from one single true seed, and, like all living things, the individual, in process of time, dies, and there appears, therefore, to be a limit to the life of any particular so-called variety of potato, since each variety is only an individual. The potato loves much manure, especially farmyard manure, but also gives good results from the use of sulphate of ammonia and superphosphate and sulphate of potash. Good cultivation is also essential for big crops. It is a crop which is particularly suited to small types of cultivation. It appears to grow in most types of soil, though it likes a fairly open kind, but plenty of spade work and manure will go a long way to remedy any excessive heaviness a particular soil may possess, and sprouting the potatoes before planting will reduce risk from early frosts. Five to eight tons per acre of potatoes represent about ordinary farm experience. Six to eleven tons per acre are recorded as market garden results. The potato contains about 75 per cent. of water, 20 per cent. of carbohydrates, and 18 per cent. of starch, but higher figures for solids can be obtained, especially where the manuring has not been so generous. In the uncooked state potatoes often prove slightly irritating when eaten, but when cooked this difficulty is removed. Potatoes can be dried by machinery for the production of potato flour. They can also, after pulping or rasping, be used for the manufacture of starch. Potato starch, after fermentation, is used for the production of alcohol.

In comparing the relative values of maize and potatoes 
for the production of starch much will, of course, depend upon the particular circumstances, but a ton of maize per acre will be a fairly good crop, and will barely produce half a ton of starch. This might be compared with about seven tons of potatoes per acre, producing rather over a ton of starch. The cultivation of potatocs, to yield good crops, is, however, expensive, in comparison with most of the cereals. Potatoes, if kept cool, can be stored quite satisfactorily. The large amount of water they contain is an objection for transport purposes in comparison with the cereals.

Sago. - The sago palm grows in tropical countries, best on boggy soils, which are rich in humus. The palms are cut down when the trunks have attained a height of about twenty feet, the sap is allowed to drain, and the trunks, sawn into lengths, split open, and the pith removed. The pith consists of starch, mixed with fibrous materials, which is then pounded in mortars, agitated with water, and the starch separated as usual. The sago flour so obtaineckis/ imported into this country, and is used for the manufincture of glucose, and in the textile industries. The gramulated sago which is made for the purpose of food is plepand from sago flour by mixing it with water into a veryCotififinlo paste, and gelatinizing by heat. "Granulated sago" is, however, sometimes made from starches of other origin than sago.

Cassava and Tapioca.-The tuberous roots of the shrub-like plants called sweet cassava and bitter cassava are cultivated in the tropics for edible purposes. Cassava flour only contains 2 per cent. albuminoids. Owing to the low demands of cassava for mineral matter, the crop is very well suited for poor, sandy soils, but it requires a good supply of air and water. The cultivation is as that of potatoes and similar manuring gives increased crops. The yield is about 5 tons per acre, producing I ton of starch and a little cane sugar. Tapioca is made from cassava starch by stirring the damp starch on hot iron plates. Cassava root contains a cyanogenetic glucoside, which develops prussic acid in the same manner as linseed (sce p. 137). As in the case 
of linseed the crops grown at high temperatures yield most prussic acid.

Barley, though a starchy cereal, is not used directly for the production of starch. The best is used for beer, the second for bread, and the worst for catt!e. It is converted into malt by steeping the grain at a temperature of from $50^{\circ}$ to $55^{\circ}$ Fahr., spread in well-ventilated spaces, and stirred well to permit germination and oxidation to take place. It is then dried at $100^{\circ}$ to $107^{\circ} \mathrm{Fahr}$. The higher the temperature, the lower is the diastase activity. It is then thrown on to screens, for the removal of the malt coombes or culms, which latter are used for feeding cattle.

(c) Cellulose.-Cellulose forms the important chemical compound which constitutes the structural part of nearly all vegetable matter. There are a great many varieties of cellulose, and the term must be taken as denoting a group, and not an individual. Cellulose is much more resistant to chemical reagents than the other carbohydrates, and is isolated from vegetable raw material by hydrolysis with acids and alkalies, or by the more drastic action of chlorine, bromine, or sulphur dioxide.

All cellulose materials condense a fair amount of moisture on their surface. In the green plant cellulose occurs in a fairly hydrated condition, but by long drying or immersion in alcohol dehydration takes place, so that the amount of cellulose obtained from a material by any method of hydrolysis depends upon the degree of hydration to which the cellulose has been subjected. This has an important bearing upon the subject of the feeding of materials containing much cellulose, since grass that is grazed by cattle in a wet condition, and has never become dry, is more digestible than the same grass after it has been dried in the process of making hay. It is well known in practical farming that hay which has been made in exceptionally dry weather is not equal in feeding value to that made in weather which does not permit of such rapid and complete drying. Cellulose enters into a feeble composition with alkalies when treated with sodium hydrate, and produces alkali cellulose, hence many forms of 
cellulose persistently retain ash, some of which has probably been in forms of partial combination. All forms of cellulose on destructive distillation yield charcoal and a distillate containing acetic acid and tar. As a rule, pure cellulose yields from 30 to 40 per cent. of charcoal, and only I to 2 per cent. of acetic acid. The effect of distilling crude cellulose, such as timber waste, is, however, very different.

Cotton.-Cotton grows chiefly in tropical and subtropical regions, and requires a fair degree of moisture and a moderately heavy soil. It grows as a small shrub, and is planted at sufficient distances to allow hoeing and picking by hand. In India two crops are sometimes obtained in a year, but, as a rule, fallow or millets (Juari, bajra) or pulses (gram) alternate. In the United States a three-course rotation is adopted, with a resulting increase in the yield of fibre. The plant yields a seed, to which the cotton fibres adhere. Some varieties have only long fibres, which are easily detached. Other varieties have, in addition, small short fluff, which refuses to come off by any simple process. Cotton fibre is a hollow, flattened, and twisted tube in the better varieties (Sea Island), from about $\mathrm{I}_{2}^{\frac{1}{2}}$ to $2 \frac{1}{2}$ inches long; in the Egyptian kind the fibres are generally from $I \frac{1}{2}$ to $2 \frac{1}{4}$ inches long, and in the Indian the fibres are usually not more than about one inch in length, but in Indian cotton considerable amounts of short fluff remain adhering to the seed. Those varieties which produce a naked seed, that is, a seed from which the long fibres are easily removed, leaving the sced naked, are commonly called black seed. Indian varieties, owing to the adhering fluff, are called white seed. After the cotton fibre has been removed, the cotton seed still has a considerable value, and is used as an oil seed (see p. I37). Cotton flowers are used for dyes. The cotton is bound with iron bands into bales, either circular or rectangular. On arrival at the mills, the bales are broken up and cleaned. The cotton fibre is then carded, passed through a drawing machine, and finally made into thread. It is then commonly woven into some kind of fabric for the production of cotton cloth. Cotton is "mercerized," 
by treatment with caustic soda, when it becomes stronger and more glossy.

Linen.-The flax plant, like cotton, has a double utility. The flax plant, or linseed, grows in temperate climates, and can be used either for the production of fibre for flax, or linseed for food and oil, but not usually with much satisfaction for both. The crop is rarely grown more often than once in six or eight years, and does not need a soil in a very high condition. Linseed is sown on the flat in well-ploughed land. Potash fertilizers are good, but phosphates only encourage weeds. The plants are preferably pulled by hand, when the plant is only two-thirds of its full height, that is, pulled about twenty inches high. The seeds are then either beaten or ripped off, and the straw or flax is retted, or rotted, by immersion in soft water. In some cases the flax stems are merely spread out on the grass, and allowed to decay with dew and rain falling upon them. This is a process which takes from two to four weeks. Under the system of pool-retting, the straw is immersed for about ten days in standing water. In some cases it is preferable to rett in running water in a stream. Combinations of the different methods are sometimes used. The fermented material is then run through a process of breaking and scutching, combed out, and finally spun like wool or cotton. Irish linen has the highest reputation, which is said to be due to the slow bleaching which takes place from exposure to the wet, pure air from the Atlantic.

Jute.-Jute is a native plant of Bengal. It requires moisture, and a fairly high temperature. It is sown in March to May, and cut in four months' time, when it is six feet high. The rough foliage having been removed, the stems are removed in a similar way to the manufacture of linen, then beaten, and combed out. The crude jute is packed into bales and then exported for use in sacking and other rough purposes. Jute, as a material for cloth, has tended to die out in India, and has been replaced by cotton materials. The lower parts of the stem often make an inferior type of jute, and are, therefore, commonly cut off 
and used for rougher material. The crude material, on arriving in this country, has to undergo a certain amount of treatment through sub-divisions by a process of combing. Jute fibre is a very crude type of cellulose, or, more strictly, ligno-cellulose, and usually contains about ro per cent. water and 30 per cent. matter soluble in acids and alkalies.

Hemp.-Hemp is used chiefly for the production of rope, and is a very crude form of cellulose. Many different plants are used for the production of hemp, but the chief hemp-producing plant, Cannabis sativa, grows about nine feet high, and is treated like flax.

Timber.-A very crude and imperfect form of cellulose constitutes the main structure of all kinds of timber. The growth of timber trees constitutes the whole science of forestry, a very large subject indeed. The hard woods, like oak and beech, grow slowly, whilst some of the coniferous trees, such as Japanese larch, grow to a usable size in twentyfive or thirty years. Timber is only economic on very inferior land or remote situations. Trees are generally felled in the middle of the summer or winter, to avoid felling them at the time when the sap is moving. After felling, the logs are sawn up into planks.

About 1660 a great move was made in planting timber, and in 1776 Dr. A. Hunter was able to tell the Royal Society "there is reason to believe that many of the ships which, in the last war, gave laws to the whole world, were constructed from oaks planted at that time" (i.e. I660 and thereabouts). 'To-day it is our Army rather than our Navy that is so dependent on home-grown timber, but we cannot congratulate ourselves on the wisdom of our fathers as Dr. Hunter did in 1776 . The resuscitation of home-grown timber production has happened before, and it must happen again.

Seasoning timber is necessary to prevent warping after use. Some form of preservative of timber for building purposes is often needed. Of these, creosote stands in the front rank, and a preparation called Burnett's Fluid, or strong zinc chloride solution (about 50 per cent.), is also used. 
It is necessary to make the preservative enter well into the pores of the wood. If the wood is at all wet, ordinary creosote fails to penetrate, but a solution of zinc chloride will work under these circumstances. Both treatments are sometimes used, giving a blue-purplish colour to the wood. By adding to ordinary creosote $I$ or 2 per cent. of wood tar, and an equal bulk of water, and adding enough sodium hydrate to make about $\frac{1}{4}$ per cent. of sodium hydrate in the total mixture, an emulsion can be produced which will penetrate well into any timber, even when other methods are unsatisfactory. These mixtures of soda, water, creosote, and wood tar can be applied cold, with a brush, to common larch and pine, giving a pleasing brown colour to fences and outhouses. Creosote can also be induced to enter into wellseasoned wood by heating the creosote, or by the use of pressure. Timber can be kiln dried when time presses.

Paper.-Many of the above types of cellulose can be used for the manufacture of paper. In former days, the materials employed for the manufacture of paper were linen, cotton rags, flax and hemp. Now, however, wood pulp, bamboo, straw, many rushes, grass, peat, beetroot refuse, potato stalks, have all found an entry into the papermaking industry. The potato stalks of town allotments could be collected economically. Large quantities of wild grass, such as Soudan sudd, are at present unused, owing to transport difficulties.

Mechanical pulp is produced by tearing wood to pulp. Sulphite pulp is produced by treating wood with sulphur dioxide and water. The solution often used is one containing about Io per cent. of sulphur dioxide, employed at a pressure of about five atmospheres at $100^{\circ}$ Cent. Disintegration takes about twelve hours, more or less, according to the nature of the wood.

The miscellaneous materials which can be put to the making of paper have first of all to be disinfected, then cut into small pieces, and run through special cutting machines. To remove greasy matters, the materials are boiled with a solution of caustic soda and caustic lime. Linen rags will 
often lose from one-third to one-fifth of their weight through the process of boiling, whilst inferior materials will lose much more. After being boiled, the material is washed, and broken up, so as to disintegrate all the fibres. When the materials used for paper-making require bleaching, chlorine gas, bleaching powder or electrolyzed magnesium chloride is used. The first named is the least satisfactory, and the last the best. The paper pulp is then separated from the water by some kind of sieve. Under old-fashioned systems this was often done by hand, but it is now mostly done by continuous machines, which separate the paper pulp from the liquors, often with the aid of a certain amount of suction, produced by a pump. The paper is rolled by rollers, sometimes with the aid of steam heat.

Destructive Distillation of Cellulose.-All forms of cellulose, when destructively distilled, produce char coal, tar, acetic acid, water, gas, and a few other special products. The crude forms of cellulose commonly used for this process introduce many other substances in small amounts. The form of cellulose most commonly used for this distillation is some form of wood which is no longer useful for other purposes. In felling timber the amount of wood useless for any of the purposes to which timber is commonly put will generally exceed in weight that of the useful material. Probably each rooo acres of wood produce forty tons per annum of woody material of no value for ordinary purposes, much of which can be destructively distilled and converted into useful products. The distillation of these materials can be divided into two separate systems, that in which the wood is brought to the still, and that in which the still is taken to the wood. Where it is possible to convey the wood to the still, the still can be constructed of fairly large dimensions. The best of these systems needs a large retort, eight or ten feet in diameter, and fifty or one hundred feet long. Two or more of these are set in a big setting, and heated with flue gases from furnaces. The temperature in the flues should be between $400^{\circ}$ and $500^{\circ}$ Cent., and the escaping products of combustion will 
be $200^{\circ}$ and $250^{\circ}$ Cent., so that considerable loss of heat occurs unless some means of utilization is devised. The wood is placed in trucks and run into the retorts. If the wood is fairly dry, 25 per cent. of charcoal will be left behind. The charcoal is preferably rapidly transported in trucks to a cooling chamber, which is often externally cooled by sprays of water. When cold, the charcoal is placed in store. The products of distillation are passed through a fractionating arrangement, which causes the condensation of the heavier tars, and then through an ordinary form of condenser, where other substances condense. The gas passing away contains considerable quantities of carbon monoxide, which is burnt in the fire and assists in maintaining the temperature. The tar which is separated in the tar separator is boiled to drive off the water which it still contains. The portion of the distillate from which the tar has been removed, commonly called pyro-ligneous acid, is then distilled, to remove the acetone and methyl alcohol, which are subsequently fractionated into pure products, with a still of somewhat similar type to that used in all industrial concerns for fractionation of volatile substances. The remaining acid is then treated with lime, at the rate of about four pounds per ten gallons liquor, when a heavy black sludge is thrown out, consisting of any excess lime and compounds of the lime with higher acids of the acetic series and polymerized forms of aldehydes. After settling for some days, the clear liquid is removed, boiled down, and, when nearly dry, run over heated rollers to obtain the acetate of lime in a fine, dry state. Many attempts have been made to produce a continuous apparatus, but such are only suited to small wood. Small vertical retorts also deal very efficiently with small wood. A very excellent article on this subject is found in Thorpe's "Dictionary of Applied Chemistry," under the title of "Wood." Where the wood is scattered over large areas, it is necessary to bring the still to the wood, rather than the reverse. For this purpose a portable plant has been designed by the author (see Bibliography). A portable machine of the type described will consume nearly all the waste wood of about 
3000 acres ordinary timber. It would also serve the purpose of any moderate-sized works dealing with about 150 to 600 tons of waste wood per annum, according to whither the machine was worked continuously or not. With small plants it is quite impractical to attempt to conserve the acetone and methyl alcohol. For the purpose of obtaining charcoal, however, small forms are more economical. The old-fashioned method of burning charcoal in heaps (see Bibliography) produces a charcoal with a high percentage of ash, which for many industrial purposes is extremely objectionable. Distillation in retorts produces a purer charcoal, but for the purpose of obtaining a charcoal with little ash larger pieces of wood only should be carbonized. For the preparation of high-class charcoal for industrial purposes a small plant is, therefore, more manageable, as it can be used to produce charcoal of any particular kind. For annealing or case-hardening steel a charcoal powder containing a high percentage of volatile matter is preferred. Where this is the case, the temperature of distillation must be kept below that stated above. Where a dense charcoal is required, long protracted heating is necessary. For average conditions the period of distillation will occupy three or four hours for each foot in the diameter of the retort. With small laboratory size retorts distillation can take place in under half an hour, but in large retorts running up to eight feet in diameter two days will be found necessary. Bigger retorts than this are not practicable. Small pieces of wood distil distinctly more quickly than large pieces. When coniferous wood is distilled, a valuable product is turpentine. A ton of hard wood on distillation gives about eighteen gallons of water with little acid in the first fraction, which is hardly worth saving, and thirty gallons of strong pyro-ligneous acid in the second fraction. The economy in treatment by this fractionation compensates for some of the disadvantages of an intermittent machine.

Charcoal from coconut shells has a high absorptive power for gases or vapours.

(d) Gum and Mucilage.-The name "gum " is a general 
term for a large group of plant products, which are exuded by wounds and are transparent. Gum arabic, obtained from the various species of acacia, is one of the best of these. The gum is obtained by artificial incision of the trees, soon after the end of the rainy season and is collected at intervals of every few days, so long as the weather permits. 'Trees of about eight to twelve years of age are usually the most productive. East Indian gum arabic, though shipped from Bombay, is very often not produced in India, but has been collected in other parts and transported to Bombay for shipment. Australian, or wattle-gum, is a product of several specis of acacia, called by the local name of wattle. Gum is much more soluble in hot than in cold water, forming a thick liquid, and is precipitated by alcohol or lead acetate. Although the gums are commonly included in the carbohydrate group, their constituents are by no means pure carbohydrate. The chief constituent of gum arabic is arabin, which, on hydrolysis, yields arabinose, galactose, and an acid of high molecular weight, $\mathrm{C}_{23} \mathrm{H}_{38} \mathrm{O}_{22}$, arabic acid.

Agar.-Agar gum, the dried jelly of seaweed, is chiefly obtained from China and Japan, but is very plentiful where there is plenty of seaweed. The special gum contained is known as gelose, which is soluble in water, weak alcohol, and alkalies. Even a solution of $\frac{1}{2}$ per cent. of agar is failly solid in ordinary temperatures. Seaweed, when boiled with water, forms the nucleus of many articles of food used in Cornwall and in Japan. It is, however, not easily digested, but is useful, admixed with milk, in preventing the formation of a hard curd in the stomach.

Mucilage.-Many seeds of plants, for example linseed, when macerated with water, produce a thick adhesive mucilage which can be used in place of gum.

\section{REFERENCES TO SECTION II, A (SUGAR)}

Collins, "Value of the Turnip as a Vegetable and Stock Food," Journ. Board of Agriculture, I9I6-1 7, p. 66.

Collins, "Variation in the Chemical Composition of the Swede," Journ. Agric. Science, i., p. 89. 
Collins. "The Relative Amounts of Dry Matter in Several Varieties of Swedish Turnips," Proc. Univ. Durham Phil. Soc., vol. iii., p. 303. (Andrew Reid, Newcastle-on-Tyne.)

Hendrick, "The Composition of Turnips and Swedes," Trans. Highland and Agricultural Soc., Scolland, I906.

Collins, "Sugar in Swedes," Journ. Soc. Chem. Ind., r9or, p. 536; 1902, p. $\mathrm{I}_{5} \mathrm{I} 3$.

Wood and Berry, "A Rapid Method of Estimating Sugar," Proceedings of the Cambridge Philosophical Society, vol. xii., part ii., p. II2.

Denbigh, "Beet Sugar as a British Industry," p. 2 I. (The National Sugar Bect Association, Ltd.)

Leather, "Memoirs of the Department of Agriculture in India," Oct., I9r3, p. Ir 3. (Thacker and Co.)

Home Counties, "Sugar Beet," p. 5. (Horace Cox.)

Leather and Mollison, "The Agricultural Ledger," I898, No. 8, p. 2. (Government Central Press, Bombay.)

Aubert, "The Manufacture of Palm Sugar," Agric. Journ. Ind., I9I I. p. 369 .

Martineau, "Sugar," p. 4I. (Pitman.)

Higgins, "Observations and Advices for the Improvement of the Manufacture of Muscado Sugar and Rum," p. 9. (Aikman.)

Mackenzie, "The Sugars and their Simple Derivatives," p. I2. (Garney.)

Collins and Hall, "The Composition of Sugar Beets Grown in the Northern Counties," Journ. Soc. Chem. Ind., I913, p. 929.

"Discussion on Production and Refining of Sugar within the Empire," Journ. Soc. Chem. Ind., I9I 5, p. 316.

Potvliet, " The Beet Sugar Industry in Canada," Journ. Soc. Chem. Ind., r9r6, p. 443 .

Orwin and Orr, "The Cultivation of Sugar Beet in the West of Ir land," Journ. Board of Agriculture, 19I5-16, p. 210; do. in Norfolk and Suffolk, I9I4-I 5, p. 969.

Leather, "Manuring Sugar Cane," Agric. Journ. India, r9o6, p. 13.

Barber, "Sugar Cane Cultivation in Godavari," Agric. Journ. India, I 907, p. 33 .

Chadwin, "The Cantley Beet Sugar Factory," Journ. Board Agriculture, I 9 I $3-14$, p. 569 .

Dowling, "The Production of Beet Sugar in a Continental Factory." Journ. Board Agriculture, I9I I-12, p. 1005.

\section{REFERENCES TO SECTION II, B (STARCH)}

Haas and Hill, " The Chemistry of Plant Products," p. 93. (Longmans and Co.)

Radhakamal Mukerjee, "The Foundations of Indian Economics." (Longmans and Co.)

Archbold, "The Manufacture of Maize Starch," Journ. Soc. Chem. Ind., 1902, p. 4 . (Vinton.)

Dyer and Shrivell, "The Mauuring of Market-Garden Crops," p. 92.

Wallace, "Indian Agriculture," p. 203. (Oliver and Boyd.)

Wiley, "The Manufacture of Starch from Potatoes and Cassava." (Government Printing Office, Washington.)

Howard, "Wheat in India." (Thacker.)

Church, "The Food Grains of India." (Chapman.)

Gilbert, "The Potato." (Macmillan.)

\section{REFERENCES TO SECTION II, C (Cellulose)}

Hall and Russell, "Agriculture and Soils of Kent, Surrey and Sussex," p. 50. (Board of Agriculture and Fisheries.) 
Watt, "The Art of Paper-Making." (Crosby Lockwood and Son.)

"Flax Growing," Journ. Board Agriculture, I9I4-I 5, p. I007.

Tom, " Department of Agriculture and Technical Instructions, Ireland," I9I 4 , p. 5 I 5 .

Nystron, "Textiles," pp. 38 and I 12. (Appleton.)

Benson and Davis, "Free Carbon of Wood-Tar Pitches," Analyst, June, I9I7, p. 2 I2.

Wallace, " Indian Agriculture," pp. 203, 247. (Oliver and Boyd.)

Roberts, " Bark Stripping," Journ. Land Agents' Soc., July, I908, p. 3 I 4.

Collins, "A Portable Plant for the Distillation of Wood," Journ. Soc. Chem. Ind., I9I 7, p. 68.

Collins and Hall, " The Use of Coal Tar Creosote and Naphthalene for Preserving Wooden Fences," Journ. Soc. Chem. Ind., I9I 4, p. 466. I033.

"The Manufacture of Charcoal," Journ. Board Agriculture, 1914-15, p.

Rowley, "The Commercial Utilization of the ' Grass Tree' (Xanthorrhoea) and 'Zamia' (Macrozamia) in Western Australia," Journ. Soc. Chem. Ind., IgI6, p. 29 \%.

Briggs, " Some Causes of Damage in the Bleaching of Linen and Cotton Textiles," Journ. Soc. Chem. Ind., I9I6, p. 78.

Briggs, "The Paper Mill Chemist in War Time," Journ. Soc. Chem. Ind., r9I6, p. 798.

Cross, "Cellulose and Chemical Industry," Journ. Soc. Chem. Ind., I9I 7, p. 531 .

Klason, Hcidstam and Norlin, "Dry Distillation of Cellulose," Journ. Chem. Soc., I908, A. I, p. 717.

Klason, Heidstam and Norlin, "Investigations on the Charring of Wood," Journ. Chem. Soc., I908, A. I, P. 955.

Boulton, "Antiseptic Treatment of Timber," Journ. Soc. Chem. Ind., I884, p. 622 .

Fletcher, "Improvement of Cotton," Agric. Journ. India, I906, p. 35 I. Stebbing, "British Forestry." (Murray.)

p. 1087 .

"Some Douglas Fir Plantations," Journ. Board Agriculture, 1913-14,

Coventry, " Rhea Experiments in India," Agric. Journ. India, 1907, p. I.

Smith, "Jute Experiments in Bengal," Agric. Journ. India, I907, p. I40.

Ellmore and Okey, "Osier and Willow Cultivation," Journ. Board of Agriculture, I9II-I2, pp. I2, 207, 557, 906.

Somerville, "Increasing the Durability of Timber," Journ. Board of Agriculture, I9II-I2, p. 283 .

\section{REFERENCES TO SECTION II, D (GUM)}

O’Sullivan, " Gum Tragacanth," Journ. Chem. Soc., Igor, T. I r64.

Schryver and Haynes, "Pectic Substances of Plants," Biochem. Journ., igr6, p. 539.

Imperial Institute Report, "Gums and Resins." 


\section{SECTION III.-THE FORMATION OF OILS IN PLANTS}

Linseed.-Linseed has already been described under the subject of linen (p. 126), but it is also used for the production of an oil seed. Where the plant is grown in cold, damp climates, the situation favours the production of fibre, but where it is grown in drier and warmer districts the situation favours the production of seed. It can be grown in many countries, but the chief sources of linseed are Russia, India, and the Argentine. Linseed contains about 35 per cent. of oil, which is expressed both on the large and on the small scale. When linseed is imported into Great Britain it is generally first of all cleaned from its miscellaneous impurities, often amounting to Io per cent., and the purified linseed run through rollers to crush it without actually expressing oil. It is then passed through a " kettle," where it is subjected either to direct steam heat, or to the heat from steam passing through a coil, or both. Linseed grown in India is very dry, and requires the moisture content to be increased, which is conveniently done by blowing steam into it. Linseed obtained from the Baltic ports is sometimes rather too damp for the process, and the steam is, therefore, passed through a coil, so as to both heat and slightly dry the linseed. The linseed is then placed between felts which are, in turn, placed between corrugated iron sheets, which are built up into a pile of twenty or thirty in a hydraulic press. The name "hydraulic press" is here somewhat of a misnomer, because in practice the liquor used in the pumps is not water, but the oil which is being produced at the time. If water were used, any leak in the press would damage the oil, but when the oil itself is used this is not possible. As 
soon as the pressure is applicd the oil begins to run out, and is collected in a well. On long standing, small quantities of mucilage are formed in the oil. For the best qualities of oil the crude oil is filtered. Linseed can be extracted with petroleum spirit, but it is very rarely treated in this way, because linseed cake rich in oil has a high value as cattle food.

Dark linseed oil is commonly refined by treatment with sulphuric acid. The refined oil is also subjected to sun bleaching in some cases. Linseed oil, in addition to the ordinary fatty acids, contains linoleic and linolenic acids. Linseed oil has a high iodine value, and is a drying oil occupying the first rank. Boiled oil is obtained by heating linseed oil to a temperature of about $I 50^{\circ}$ Cent., with the addition of driers, which often contain manganese and lead. Linseed oil is also vulcanized by sulphur chloride to form a rubber substitute (see p. I65).

The remaining linseed cake as it comes out of the press is still somewhat warm, and is sometimes dipped in water, to give the cakes a bloom. It is then sold for cattle food. Under ordinary farm conditions, where the chief part of the home-grown food consists of hay, straw, turuips, and tail corn, the purchase of a food containing some oil is highly desirable, and linseed is one of the most popular of these materials. Linseed cakes generally contain about II per cent. of oil, rather less in those of American manufacture, rather more in those of Russian origin, about 32 per cent. of albuminoids, rather more in cakes of American origin, and rather less in cakes of Indian origin, and do not contain more than about 7 per cent. of fibre. Linseed cake is reckoned as one of the safest of cattle foods, and is a favourite for rearing calves on. Linseed contains a cyano-genetic glucoside called linimarin, which, by the action of the proper enzyme, contained in the linseed, will develop prussic acid, acetone, and glucose under certain conditions. If ground linseed cake be placed in water at temperatures between $20^{\circ}$ and $60^{\circ}$ Cent., the action of the enzyme on the linimarin will begin. The rate at which the prussic acid is evolved 
depends upon a variety of circumstances, which are not very likely to occur under ordinary conditions of feeding, but which may be found when the feeding is conducted on careless lines. It happens that linseed grown in hot climates contains more poison than linseed grown in Great Britain, but since it is also drier, the manufacturer uses steam before pressing it, thus undesignedly counteracting the poison. The extent to which this takes place varies according to the details of manufacture in the works concerned. There is extremely little risk of adult animals in good health being poisoned. So long as the seed is fed whole, or only simply crushed, there is little risk of poison being formed, but if linseed cake in the form of fine meal is partly mixed with warm water, it remains in the form of small balls. Calves, if fed with such badly made linseed mash, do not properly chew the balls, but swallow them whole, so that they break up in the stomach and liberate the prussic acid. Where linseed, or linseed meal, is actually boiled with water, the cnzyme is completely destroyed. Once the enzyme has been checked by the action of acid or alkali it is not able to recover its old vigour. A degree of acidity equal to $\frac{1}{1000}$ normal hydrochloric acid is sufficient to check the activity of the enzyme. Where care is taken in the preparation of the meal no poisoning cases arise. Linseed, like most of the oil seeds, contains no starch.

Cotton. - The growth of the cotton plant has been already described, and its use for the manufacture of fibre (p. I25). After the cotton fibre has been removed from the seeds, the latter form a valuable part of the crop. Like linseed, cotton seed is rich in oil, containing about 30 per cent., although some varieties, especially those of Indian origin, are all lower in their oil content. Oil obtained from fresh seed is paler in colour than that from old seed, but the latter is clarified by washing with caustic soda and cooling till stearin separates out. Cotton-seed oil is not a drying oil, like linseed, and is used for lubricating purposes, and for replacing olive oil, butter, and other edible fats.

Owing to the large amount of husk enclosing the cotton 
seeds, the fibre amounts to I8 per cent. Two systems of pressing the cakes have arisen. (I) Where the seed is pressed whole, the husk remains in the cake, and whilst it provides a good channel for the escape of the oil, it acts as an absorbent, and prevents some of the oil flowing out. (2) Where the husk is removed, a lower pressure suffices, but it is not possible to leave the cake with as low a percentage of oil. There are, consequently, many types of cotton cake put upon the market. The Indian cotton cakes derived from seed grown in India and pressed in England usually contain about $4 \frac{1}{2}$ per cent. of oil, I9 per cent. of albuminoids, and 2 I per cent. of fibre, and are often dirty and sandy. The short fluff remaining on the seed hinders cleaning previous to pressing. Most Egyptian cotton cakes contain about 5 per cent. of oil, 23 per cent. of albuminoids, and I9 per cent. of fibre, and have a somewhat higher feeding value than Indian cakes. Decorticated cotton cakes are produced in America by removing the husks of the seed previous to pressure. These usually contain II per cent. of oil, 40 per cent. of albuminoids, and 8 per cent. of fibre, but great variations occur. Where these cakes are extracted by petroleum spirit the percentage of oil is reduced, and where the decortication is indifferently performed the fibre may rise to 15 per cent. At one time there was a habit of treating Indian cotton cakes with small quantities of borax, for the purpose of preventing fermentation and subsequent discoloration. The fashion, however, appears to be dying out.

The Soy Bean.-The soy bean is grown very largely in Japan and Manchuria, as well as in other parts of the world. Many crops of soya-bean seeds only contain I6 per cent. of oil. The oil is pressed in the same way as the other oil seeds named above, and the resulting cake contains about 6 per cent. of oil, 42 per cent. of albuminoids, and 5 per cent. of fibre. Soya-bean oil belongs to the drying class of oils, but it is not equal to linseed in this respect. The cake remaining is a particularly palatable one, and much appreciated by all cattle. The bean itself is frequently used for human food in the East, and experiments are being made to 
grow soy beans in Australia, South Africa, the United States, Italy, Spain, South America, and even in the British Isles. In the crude preparation of the oil in Manchuria the beans are soaked in water over-night, crushcd, and boiled with water, so that the oil cells are broken. The oil is then expressed in a very primitive press. In spite of the primitive character of this method of preparation, as much as I3 per cent. of oil is said to be expressed, at the expenditure of much labour and time, whilst modern machinery rarely succeeds in extracting more than I2 per cent.

Palm Nuts and Coconuts. - The coconut palm is a tree growing to a considerable height, chiefly inhabiting the sea-coasts of the tropical regions. It is propagated from the nuts in nurseries and planted out. About 7 tons of coconuts can be obtained per acre of plantation. The coconut is dehusked and dried, and the resulting material, known as copra, is expressed for its oil. The palm kernels contain nearly 50 per cent. of oil. The oil so obtained from the palm nuts or the coconuts, on cooling, throw out much solid material, which can be used for the manufacture of margarine or soap. The remaining cakes are of the following composition. The coconut cakes vary from about 7 to I2 per cent. of oil, from I9 to 22 per cent. of albuminoids, and Io to 13 per cent. of fibre, whilst the palm nut cakes vary from about 7 to Io per cent. of oil, from about $I 7$ to 2I per cent. of albuminoids, and II to 16 per cent. of fibre. The palm kernels are not infrequently extracted with petroleum spirit, in which case the oil in the residue, which is often sold as palm kernel meal, is as low as I to 3 per cent. of oil. Whilst coconut and palm nut cakes and oils have a considerable degree of resemblance, there are some points which differentiate them, both in their history and in the character of their products. The coconut has been known since the earliest times as a food material in India, and the South Sea Islands. When unripe they are often used as drinking coconuts-that is, they are removed from the trees in the green condition, the top sliced off, and the "milk," which looks more like ginger beer, drunk from the shell. 
For the preparation of oil the primitive system consisted in removing the husk, cutting up the kernel into small pieces, exposing in piles to the leat of the sun, so that the oil ran off and was collected. Another method was that of pulping the kernels and placing them in a kind of sieve exposed to the sun, when the oil ran off and was collected. Sometimes artificial heat was used. In India the dried kernels were ground in the primitive oil press, or were thrown into boiling water and the oil skimmed off. The residueswere often used locally for cattle food. The dried husk, known as copra, is liable to ferment, due to the presence of water, and many of the difficulties of manufacture and the prejudice against the materials resulted from this cause. Modern systems eliminate much of this difficulty, by first removing the fibrous matter (coir) and then striking the nut on a sharp spike. The husk is removed by hand and the nut split, drained and put in the sun to dry. Sun-dried copra gives better quality oil than that which has been dried in kilns, but improvements in the kiln system of drying are likely to remove this difficulty. The coconut shells are used for firing the kilns (see p. I3I). In the modern system of pressure, two pressings are carried out, the temperatures adopted being higher than those used for linseed as described above. About 65 per cent. of oil can be obtained from the best qualities of copra. Owing to the fermentive changes alluded to above it is not infrequent for considerable quantities of free fatty acid to be present in the oil, but the great care taken in modern manufacture tends to reduce this degree of acidity. Owing to its high melting point, coconut oil is not infrequently met with in the solid or semi-solid condition. Although coconut oil requires a high strength of alkali and high temperature for saponification, yet with alkali of the right strength soap is formed at ordinary temperatures. Soap made from coconut oil is soluble in weak salt solutions and is used for washing in sea-water. Although this confers an advantage in certain uses of the soap, it compels the manufacturer to employ more salt to throw soap out of solution in the boiling vat. 
The oil palm tree, which gives the palm kernel oil, more frequently grows inland in open country and bush land, in contradistinction to the coconut, which grows chiefly on the sea border. Neither trees are commonly met with at any considerable altitude. The rough method by which the palm nuts are collected causes much injury to the kernels and results in subsequent hydrolysis of the oil. The outer layer of the fruit is removed for making palm oil, and the nuts are shelled. In the rough preparation the kernels are often fermented before pressing, which also causes the same difficulty alluded to above in coconut oil. The rough purification of this crude oil is often carried out by boiling up with water. Palm oils not infrequently have as high as one half of their total amount of fatty acids in the free condition, accompanied, of course, by the corresponding amount of free glycerine. In recent years the palm kernels have been brought into Great Britain and have been pressed in home machinery of modern type. The result has been that much superior oils have been obtained, with far less free fatty acids, and the resulting oil cakes have also been superior. The oil is mostly used for soap, candles, and margarine. Whilst many of the early makes of both cakes were distinctly rancid, yet the modern cakes are relatively free from this objection. Nevertheless, cattle do not take kindly to either of these cakes at first. It is usually less difficult to persuade cattle to eat coconut cake than palmnut cake. When coconut cake has been only slightly pressed it is very apt to absorb moisture so readily as to break itself up and burst the sacks in which it has been placed. As much as Io per cent. of water may easily be absorbed by such cake when standing in ordinary barns on the farmstead. As, however, this difficulty has become recognized, and as the oil is very valuable, manufacturers are now usually taking greater care to press the cakes more completely, and they are thereby producing a bigger yield of oil and at the same time a cake which, though it may look less satisfactory on analysis, is more practically useful, because it does not absorb water nor turn rancid on storage. Palm kernel 
cake has a very dry and unsatisfactory flavour. Unless it be mixed with some damp food the cattle will merely blow it away with their noses, and never eat it at all, but if it be moistened, or mixed with turnips, the cattle, after a little experience, can be induced to eat it. The difficulty under this head is only what has been observed on many occasions before, cattle do not take readily to new-fashioned food, and it takes a good deal of patience and persuasion to induce them to eat something they have never tasted before. In time, of course, these difficulties are overcome.

Earth Nuts. - The earth nut, or ground nut, is a tropical annual leguminous crop which has the peculiarity that the fruits bury themselves in the earth. It will grow in sandy soils, is very valuable as a course in tropical rotations, and lends itself well in conjunction with cotton on irrigated light land. In some cases the ripe fruits are actually dug out of the earth, or in others the crop is taken before the fruits have had time to enter. Earth nuts are largely grown in Madras, and shipped from Pondicherry to Marseilles. The best qualities come from Rufisque, in Senegal. Sometimes the pods are removed from the beans, and sometimes the materials are pressed whole. The actual bean contains about 40 to 45 per cent. of oil, and 28 per cent. of albuminoids. Earth nuts are not infrequently fractionally expressed, the best quality oil, cold drawn, being expressed at the ordinary temperature, and one or two other fractions made at increasing temperatures afterwards. The best qualities of oil, that is, those that are cold drawn, are used in the manufacture of salad oil, and the second qualities for the preservation of sardines, and the manufacture of margarine. The lowest quality, that expressed at the highest temperature, is used for soap-making. A characteristic fatty acid of earth nuts is arachidic acid. Earth-nut oil is a non-drying oil. Earth-nut oil is largely used to replace olive oil in all its uses. When the husks are removed, the resulting cake contains 7 to 9 per cent. of oil, and 45 to 48 per cent. of albuminoids, and 5 to 7 per cent. of fibre. When the husks have not been removed, the fibre may vary from about 
I8 to 30 per cent., with a corresponding reduction in the other constituents. The resulting cake is highly esteemed as a cattle food, being of a very palatable nature.

Rape Seed (Colza, Sarson).-Rape seed is grown in European countries and also very largely in India. The bulk of the East Indian seed is imported from Calcutta, Madras, and Bombay, the large-growing districts being in Guzerat and Ferozepore. Rape seed contains about 33 to 43 per cent. of oil, 22 to 27 per cent. albuminoids, and 4 per cent. fibre, the French seed being the richest in oil. It is crushed between rollers in the same way as the other oil seeds. The crude oil is dark coloured, and generally needs to be refined by treating at the ordinary temperature with about I per cent. strong sulphuric acid. The cold-drawn oil is used in India as an edible oil. The oil is also used for lubricating purposes, and for the manufacture of soap. The cakes obtained after pressing the oil are of somewhat doubtful utility for feeding cattle. Rape seed often contains materials which develop a mustard oil after hydrolysis by an enzyme. The amount of proper enzyme in rape is commonly deficient, but the admixture of mustard seed provides the necessary enzyme for developing the mustard oil. The problem is, therefore, parallel to the development of prussic acid in linseed. When the cakes are perfectly pure, and free from mustard seed, and have not become acted upon by heat and moisture, the material may be fed with safety, but there is always the risk that either insufficient cleaning in manufacture, or improper systems of feeding the cattle, may give rise to the development of mustard oil, which is pungent and irritating to the animals, and has been reported to have actually caused death.

Safflower Seed. - This plant has been grown in India to a large extent, originally for the preparation of saffiron dye, but the seeds are also pressed for their oil. They are rich in oil, containing 30 to 35 per cent., but, owing to the very thick, springy husk, great difficulty occurs in expressing the oil, but the oil is prepared in India on a small scale for local purposes, being largely used for human consumption. 
On the small scale, it is not infrequent to mix the safflower seed with other seeds before pressing. Safflower oil has good drying properties, but not equal to linseed. It, nevertheless, can replace linseed for such purposes as preserving ropes, etc., from the action of water and air. It is used in India also largely for decorative purposes, the "wax cloth" being largely made by drawing artistic designs with the aid of this oil, and then dusting on mica, or other glistening materials. The saffron dye is made from the yellow florets, which are plucked and dried.

Sesame, Gingelly, Til Seed (Sesamum Indicum).This is an annual plant grown throughout the tropics and sub-tropics. Sesame seeds are rich in oil, containing from 45 to 57 per cent. of oil and usually have to be pressed more than once. The bulk of the business has previously been carried out at Marseilles, where a cold-pressed oil is obtained first, and then further oils obtained by the addition of water and the raising of the temperature, by which means another Io per cent. can be obtained. The best quality oil, cold pressed, is a good, colourless and odourless oil, but that obtained from the later pressings is of inferior quality. Sesame oil is a slow-drying oil, and is liable to become rancid with considerable rapidity. It can, however, be used as a substitute for olive oil, and is used in the manufacture of margarine, the lower qualities being used for soap-making and for rather inferior lubricating oils. The cake contains about 30 to 40 per cent. of albuminoids and only 6 per cent. fibre.

Niger Seed is a plant originally coming from Abyssinia, but is now also cultivated in India. The seeds contain about 40 per cent. of oil, I9 per cent. albuminoids, and I4 per cent. fibre, whilst the cake contains 30 to 35 per cent. albuminoids and 18 per cent. fibre.

Mowha or Mowra Seed (Bassia Seed).-The two species of bassia which provide the mowha seed are grown in India and Ceylon, one species grown in the northern or extra-peninsular portion, and the other in the southern or peninsular portion. Mowha fat is soft and yellow, like 
butter, and can be used for edible purposes. It is removed from the mowha kernels in the same way as most forms of oil. The cake left after crushing the oil contains much saponin, a poisonous glucoside. The cake has been fed to cattle without actually killing them, but the feeding results have been very unsatisfactory. Efforts have been made to extract the saponin by a commercial method, but, up to the present, no particular success has resulted. Mowha cake, as well as the true soap nut, has been used for exterminating worms from lawns, and for several other horticultural purposes. As the mowha cake has some manurial value, and is relatively rather rich in potash, after the saponin has done its work of destroying insect life, it serves as a manure, the nitrogen amounting to $2 \frac{1}{2}$ per cent. and the potash to $I_{\frac{1}{2}}$ per cent.

Hemp Seed Oil.-Hemp has been referred to for its fibre (see p. I27), but the seed can also be pressed for its oil. When fresh drawn, the oil is of a pale colour, but soon becomes darker on keeping. It is used for illuminating purposes, for soap, and also in varnishes.

The Essential Oils. - The greater number of these oils are used as scents, requiring a special trade, but of the common materials under this class, oil of turpentine is the most important. Many species of pine trees serve as sources for this material. Under the best systems, after carefully removing the bark, vertical incisions are made in the tree. Sticky resinous matter oozes out, and is received by a cup, which is placed immediately under the slits. These slits are gradually extended in an upward direction, and the cups follow them. When the crude exudation of the trees is distilled with water, oil of turpentine distils over, and the remaining material is known as colophony or rosin.

\section{REFEIRENCES TO SECTION III}

Souchida, "Notes on Some Fatty Oils," Joum. Soc. Chem. Ind., 1916, p. 1089.

Imperial Institute Monograph, "Oil Seeds and Fecding Cakes." (Murray.)

Leathes, "The Fats. Monograph on Bio-chemistry." (Longmans.)

D. 
Collins, "The Rate of Evolution of Hydrocyanic Acid from Linseed under Digestive Conditions," Proc. Univ. Durham Phil. Soc., I9I2, iv. p. 99; Journ. Chem. Soc., I9I2, A. ii. 586.

Collins, "The Feeding of Linseed to Calves," Journ. Board of Agriculture, I9I 5-16, p. I 20.

"Linseed as a Farm Crop," Journ. Board of Agriculture, I915-I6, p. 1069.

Morrell, "Polymerized Drying Oils," Journ. Soc. Chem. Ind., I9I5, p. 105.

Hyland and Lloyd, "The Oxidation of Fatty Acids," Journ. Soc. Chem. Ind., I9I 5, p. 62.

Maidment, "The Home Dairy," pp. ${ }_{3}$ and 94. (Simpkin, Marshall.) Collins and Blair, "The Liberation of Hydrocyanic Acid from Linseed," Analyst, 19r4, p. 70.

Fowler, "Bacterial and Enzyme Chemistry," p. x6o. (Arnold.)

Voelcker, "The Characters of Pure and Mixed Linseed Cakes." (Clowes.) Journ. Roy. Agric. Soc.

Vakil, "Cotton Seed Products," Journ. Soc. Chem. Ind., 1917, p. 685.

Crowther, "Palm Kernel Cake," Journ. Board of Agriculture, I9I6-I7,

p. 734 .

Crowther, "Palm Kernel Cake and Meal as Food for Pigs," Journ. Board of Agriculture, I9I6-I $\%$, p. 850 .

Browning and Symons, "Cocoanut Toddy in Ceylon," Journ. Soc. Chem. Ind., I9I6, p. II38.

"Ground Nut Cake," Journ. Board of Agriculture, I9I5-16, p. 308.

Collins, "Agricultural Chemistry," p. I4. : (Government Printing Office, Calcutta.)

Roure Bertrand Fils, Bulletins. (Grasse, France.)

Copeland, "The Coconut." (Macmillan.)

Dunstan and Henry, "Cyanogenesis in Plants," Proc. Roy. Soc., I903, p. 285 .

Auld, "The Hydrolysis of Amygdalin," Journ. Chem. Soc., I908, T. $125 \mathrm{I}$.

Bulletin Imperial Institute, “Palm Kernels," I9I4, p. 459.

"The Cultivation of Soy Beans in Britain," Journ. Board of Agriculture, I9I2-I9I3, p. 33 .

"The Growing of Linseed for Feeding Purposes," Journ. Board of Agriculture, I9I3-I4, p. 377.

Eyre and Fisher, "Some Considerations affecting the Growing of Linseed as a Farm Crop in England," Journ. Agric. Science, vii., p. I20.

Mitchell, "Edible Oils and Fats," p. 24. (Longmans.)

Parry, "Gums and Resins." (Pitman.) 


\section{SECTION IV.-THE NITROGEN COMPOUNDS IN PLANTS}

As the study of the animal proteins already forms the chief subject matter of one of the other books of this series (Bennett), it will only be necessary to indicate in this section some of the differences occurring between the vegetable proteins and the animal proteins, and to give details of nitrogenous bodies other than proteins.

The Cereal Proteins. - In the eighteenth century a considerable amount of work was done in examining the protein matter in wheat. In I747 Beccari examined wheat flour, and concluded that wheat gluten resembled animal matter. The process chiefly used in that day was destructive distillation. Kessel Myer, in I759, determined the action of various sulphates upon wheat gluten, and in I 773 Rouelle showed that the wheat gluten was also present in various other plants. Parmentier showed that wheat gluten was insoluble in mineral acids, but soluble in vinegar, and that there was some relationship between the colour of flour and its gluten content. In the nineteenth century the solubility of wheat gluten in alcohol was also considered, and the elementary position of the proteins began to be accurately studied. Destructive distillation at this period seems to have been the method of the investigators.

The chief protein in wheat grain is now called glutenin, and the next most important gliadin. These are contained in slightly greater quantities in spring wheat than in winter wheat, but this variation is very likely due to the longer period during which winter wheat grows. Reserve seed proteins are usually more stable towards reagents than the proteins which form part of the living substances of the 
plant, and the composition of the reserve proteins appears to vary more than does the composition of the proteins that take part in the active life of the plant. Extraction with somewhat diluted alcohol has been employed to remove some of the proteins of cereal seeds, although in other seeds such extraction with alcohol yields but little protein. Extraction with alcohol can be made at any temperature up to its boiling point, if the alcohol is sufficiently concentrated to inhibit hydrolysis. By evaporating such a solution in fairly strong alcohol, the alcohol evaporates first, the percentage of water increases, and the proteins become insoluble. On the other hand, from fairly concentrated solutions protein may also be separated by adding absolute alcohol, since in absolute alcohol proteins are insoluble. The addition of ether assists in this precipitation of protein. Roughly speaking; solutions containing less than $5^{0}$ per cent. of alcohol, or more than 93 per cent. of alcohol, do not dissolve cereal proteins. Other alcohols than ethyl alcohol can be used for solutions. Zein, from maize, can be dissolved in boiling acetic acid without any apparent change, and is also particularly resistant to the action of alkalies, even 2 per cent. of potassium hydrate at $40^{\circ}$ Cent. during 24 hours giving little evidence of alteration. Zein also shows a unique behaviour towards alcohol, because, when dissolved in strong alcohol, the solution becomes gelatinated. In such circumstances, however, the original nature of the protein appears to be permanently altered. The globulins differ in a marked degree from the animal proteins, for most of them are very incompletely coagulated by heating the solution, even to boiling point. The vegetable proteins have a fairly marked specific rotary power towards polarized light. Gliadin, from wheat, rye, and barley, has a high rotary power, corresponding to about - $100^{\circ}$; but zein, from maize, has a relatively low specific rotary power of about $-30^{\circ}$. The hydrolysis by acids of the vegetable proteins are of much the same general character as those from the animal proteins. The vegetable proteins are generally more difficult to completely hydrolize than the animal proteins, and a 
much longer hydrolysis is generally found necessary. The amino acids which have been obtained from the vegetable proteins are the same as those yiclded by the animal proteins with the exception of di-amino-trioxy-dodecanic acid. In general, the plant proteins yield more glutaminic acid and ammonia than do the animal proteins. The proteins soluble in alcohol yield the basic amino acids in a very small pro portion, and yield no lysine. The vegetable proteins always contain more nitrogen than the animal proteins. The splitting products of the cereal proteins are marked by the high proportion of non-basic nitrogen, the low proportion of basic nitrogen, the high proportion of ammoniacal nitrogen, and the small amount of lysine. Glutenin and gliadin, both wheat products, are characterized by the high yield of ammonia in comparison with the glutaminic and aspartic acids present. These proteins must, therefore, contain some nitrogen not occurring in the usual type of amino-acid amide like asparagine. A marked division between the cereal proteins and those of animal origin lies in the fact that the former are completely free from phosphorus. Of course, imperfectly purified specimens will contain some phosphorus adhering to them. A very important correlation is brought out when the character of the proteins in the seeds is compared with the ordinary botanical relationship of the natural orders concerned. The proteins contained in the seeds of the cereals contain a relatively large proportion of those protamins which yield no lysine, much proline, glutaminic acid, and ammonia, with a little arginine and histidine. Hordein, in barley, is characterized by its low percentage of oxygen and large heat of combustion.

The chief properties and behaviour of the cereal proteins are much alike, and present marked differences from the proteins from other groups of seeds. It is thus found that similar proteins are found only in seeds which are botanically closely related. The embryo in its early periods of growth is fed on special food, but when the plant has reached the stage of finding food from its surroundings, the chemical processes have already become established on fixed lines. 
Wheat grown on irrigated land contains less nitrogen than that grown on non-irrigated land, but this may quite possibly be only part of the general principle that vigorous growth results in the production of carbohydrates.

Crude gluten from wheat amounts to 8 to 5 per cent. of the wheat flour, No. I Manitoba wheat flour containing over I3 per cent. and English flours under Io per cent.

Crude gluten dried at a low temperature is used to make biscuits for diabetes patients.

Leguminous Proteins. - Many of the leguminous seeds, such as peas, beans, and lentils, contain relatively much protein soluble in water, which, after the addition of acetic and carbonic acids, is largely precipitated. but is soluble again in concentrated saline solutions, and is generally considered as a globulin. It was formerly supposed that many proteins were strong acids in all but name, and formed salts with bases, on which grounds many of the proteins were described in older literature as caseins. The legumin from peas and beans was long regarded as a protein of strong acid character. Recent studies have, however, shown that the solubility caused by the addition of large quantities of alkali is not due to this. Legumin in the free state is soluble with water, but when combined with acids forms salts which are insoluble, and the idea that legumin is a strong acid in a free state, but forming salts, is no longer a tenable hypothesis. Many of the leguminous seeds, when freshly ground, yield water extract, from which the protein separates by the development of acid. The separation can quickly be effected by adding a small quantity of any common acid. Legumin, previously dissolved in dilute sodium hydrate, is not precipitated by adding enough acid to combine with all the alkali that has been added, but very little more acid forms an insoluble salt of legumin. Still further addition of acid, however, suffices to redissolve the precipitate. The leguminous proteins are usually particularly rich in nitrogen, and yield on hydrolysis a large proportion of arginine.

Vicilin, from peas, is characterized by the small amount 
of ammonia in proportion to the amount of glutaminic and aspartic acids, and must, therefore, contain those amino acids in a form different from that of the amide. This protein has also been found to contain very little sulphur. The proteins from leguminous seeds resemble one another in many respects, but differ from those of the cereals. The proteins of the pea, horse bean, lentil, and vetch all yield preparations of legumin which are apparently identical. Other members of the leguminous seties yield proteins which are very similar to those yielding legumin, and though not identical, are much nearer to legumin than any of the proteins found in the cereals. The legumin of soy bean is used in Japan to make a vegetable cheese. The soy beans are treated as in the manufacture of starch (see p. II7), but the non-starch residue is kept, boiled, strained, and precipitated with brine. The cheese resembles a half milk cheese.

The Proteins in Root Crops.-Early investigators examined the proteins of the potato, but no great amount of work has been done in this group. The hydrolysis of the protein of the swede turnip produces substances which differ from those yielded by the legumins chiefly in the following points:-The percentage of arginine resembles that yielded by the cereals, and is distinctly less than that from the leguminous crops. The percentage of histidine is rather high. The percentage of lysine is fairly high, and corresponds to that from the legumes. The low content of glutaminic acid in the soluble protein of swedes will counterbalance the high content of that amino acid in the proteins of cereals when these two are fed together, as is common in ordinary farm practice. Both cystine and tryptophane are also present in the swede protein.

The Proteins of the Oil Seeds. - The globulin in castor bean can be freed by dialysis from all but minute traces of the toxic substances contained in the beans, a fact which forms one of the best pieces of evidence that these materials can be obtained in at least some degree of purity. Edestin, the chief protein of hemp seed, is entirely insoluble in water, 
but is very readily soluble in small traces of acid, in the absence of other salts. From such a solution the edestin is readily precipitated by sodium chloride. Edestin, in fact, has proved to be a fairly strong base, and the combined acid in its salts can be titrated by potash and phenol-phthaleïn.

The maximum acid binding power of edestin is very high indeed. The solubility of edestin in salt solutions is approximately the same, but the iodides and bromides dissolve edestin more readily than the chlorides. Acetates behave in a somewhat remarkable manner, for the acetates of the alkalies have no solvent action on edestin, while the acetates of heavy metals dissolve it freely. The acetates of lead, copper, and silver, which are commonly supposed to be protein precipitants, are as good solvents for edestin as is pure acetic acid, provided other salts be absent. The metallic ion of the acetate unites in organic combination with the protein. Corylin, from hazel nuts, is characterized by containing the very high amount of I 9 per cent. of nitrogen, of which nearly one-third is basic nitrogen. The proteins in this group are, on the whole, characterized by high percentages of nitrogen, with moderate amounts of ammonia, and very high amounts of basic nitrogen, with large quantities of arginine and moderate amounts of histidine. The castor bean contains toxic substances, which appear to be of protein character, although this is not accepted by all workers, but preparations have been made of ricin, of which $\frac{1}{2000}$ part of a milligram per kilogram weight was a fatal dose when subcutaneously injected into rabbits, and such rich preparations contain a high percentage of albumen.

The Alkaloids.-Opium is the dried milky juice (latex) of the unripe capsules of the poppy. The opium poppy is cultivated in India and China from seed, which is sown from November to March, and the crops are ready from May to July. A few days after the petals have fallen the capsules are cut round the middle with a knife, and on the following morning the juice has flowed out, hardened, and is ready for collection. After further drying on poppy leaves, the dark masses are made up into lumps. Opium is used medicinally, 
and also is smoked, chiefly by the Chinese. Opium contains many alkaloids-morphine about 9 per cent., narcotine about 5 per cent., and other alkaloids about I per cent. Morphine exists in opium in the form of two soluble salts, so that extraction with water removes all this alkaloid. Gregory's method for the manufacture of morphia consists in extracting the drug with water at about $40^{\circ}$ Cent., mixing the liquor with excess of calcium carbonate, and evaporating to a small volume. Calcium chloride is added to a slight excess, the liquid diluted, and a precipitate, consisting of resin and calcium meconate, filtered off. On concentrating the liquid the hydrochloride of morphine crystallizes out. This is dissolved in water, the solution decolorized with charcoal, and decomposed by ammonia, which precipitates the morphia nearly pure. Further purification is effected by ether and benzene.

Cinchona (Peruvian Bark). - The tree which yields this bark is a native of Peru, and the value of the bark for curing intermittent fevers was known to the American natives before the conquest of Peru, but they concealed its value for a long time. In 1638 , however, the Countess Cinchon obtained the use of this for the cure of fever, and subsequently brought quantities of ground bark to Europe, where it was known by the name of the "Powder of the Countess." Subsequently it became known to the Jesuits, and was usually called "Jesuit's Bark." Three kinds of bark are commonly known, the pale bark, the yellow bark, and the red bark. The cinchona trees are now cultivated in many parts of the world, considerable quantities being grown and manufactured in India under Government supervision. The use of plain bark is no longer very large in medical practice, being replaced by the purer drugs. The total alkaloids of Peruvian bark are first extracted with water, and dissolved for the most part. The cincho-tannates may be dissolved by a dilute acid, or they may be decomposed by mixing the bark with lime and water. Extraction with dilute hydrochloric acid is not usually employed now. On the large scale, finely powdered bark is mixed with lime, 
and made into a paste with water. The mixture is thoroughly dried, powdered, and extracted with chloroform, ether, etc. The alkaloids are removed from the solvent by agitating it with dilute acid, and then precipitated by ammonia. The alkaloids thus obtained are chiefly composed of quinine, hydroquinine, cinchonine, cinchonidine, and a little quinidine. Crude alkaloids of this nature are not infrequently employed as medicine, especially in India, where they may be sold under such titles as cinchona febrifuge, sometimes misnamed by the natives as cinquinine. A nearly complete separation of the quinine may be effected by taking advantage of the small solubility of quinine in cold water. Quinine is a fairly strong base, giving two sets of salts, mono-acid and di-acid.

Nicotine.-Nicotine is prepared chiefly from the tobacco leaf, mid-ribs, and waste tobacco, and from the liquors which are by-products of tobacco intended for chewing purposes. These materials are extracted with water, and the liquor concentrated. After the addition, steam distillation gives a liquor containing a crude form of nicotine. This is acidified with oxalic acid, and evaporated to a small bulk, subsequently decomposed by potash, and the nicotine floats on the surface, and is separated mechanically. Waste tobacco and crude forms of nicotine are largely used as insecticides, especially for horticultural work.

Tobacco.-Tobacco can be grown in the British Isles where the cool moist temperature on the west coast makes the tobacco plant fairly independent of variations of soil moisture, which is such an important point in all tobacco-growing districts, and perhaps accounts for the fact that on the west coast of the British Isles small degrees of frost are not found to be fatal, whilst on the European continent a frost is considered a fatal difficulty. Any good soils can be made suitable by tillage for the production of tobacco, but the plant flourishes best in a fairly open soil, which is well supplied with organic inatter.

Tobacco is especially sensitive to the amount of lime in the soil. Continental practice considers that the amount 


\section{THE NITROGEN COMPOUNDS IN PLANTS 155}

of lime in the soil should not be less than $\frac{1}{2}$ per cent., and not more than 2 per cent.

The manures used contain a high percentage of potash, but no large amount of phosphates. The fields on which tobacco is planted out must be well sheltered from wind. 'Tobacco may be substituted for potatoes or other crops in the rotation or can be grown several years successively. On the continent phosphates are not usually applied direct to the tobacco, the previous crop in the rotation having already received hcavy dressings of phosphates in advance. Chlorides are considered bad for the development of the plant. Compound manures containing about 5 per cent. nitrogen, I7 per cent. soluble phosphate, and 7 per cent. potash are considered very suitable for this crop, which corresponds roughly to about one part of sulphate of potash, two parts of sulphate of ammonia, and four parts of super-phosphate. Kainit should not be used since it contains too much chlorine. The plant is usually grown on low, flat drills, very frequently being planted out in the furrow, and subsequently earthed up. The secd is generally sown about the middle of March or April in hot beds. The suckers and lateral growth should be broken off, and the plant allowed to bear ten leaves. The better qualities are not harvested all at once, but plucked leaf by leaf. They are then dried, and taken to curing barns, in which ventilation is an important point. The first process consists in wilting the leaves, when they lose moisture, and become limp, but the drying should not take place too fast. The second process is that of yellowing the leaf. This subsequently turns to brown, and the leaf becomes fairly woll dried. Then drying must proceed fairly rapidly, in order to prevent mould setting in. About one half of a ton of dry tobacco per acre represents the ordinary yield.

In tropical climates a rich, sandy loam is preferred, containing considerable quantities of potash and lime. In India a great many of the most suitable districts contain well waters with nitrates in solution, which are used for irrigating purposes. The land is usually thoroughly ploughed 
and thrown up into riggs and furrows. The seeds are sown in nurseries in a shady situation, and in very hot districts it is necessary to protect the seedlings from excessive heat at this stage. Some form of partial sterilization of the soil is often adopted by burning the soil, along with weeds, brushwood or other waste. The seedlings are generally transplanted into furrows, where they may possibly be irrigated, and the position of rigg and furrow subsequently reversed in the process of eartling up. Growth has usually proceeded fairly far in thirty or forty days, when side shoots and small buds are cut off. In the fields twigs and sticks are arranged somewhat like a towel-horse, and the leaves arranged on these for drying purposes. In some cases the leaves are fixed to strings, very much like a washerwoman might hang out stockings to dry. Rapid drying produces a pale leaf, but slow drying produces a dark-coloured leaf. The process of maturing does not consist in merely losing water, but the action of oxidizing enzymes is an important part of the process. The starch and sugar almost entirely disappear, and the albuminoids and the tannin decrease, with an increase in the amounts of amides. These changes are all explained by ordinary oxidizing decomposition.

Caffeine or Theine. - This is the alkaloid of tea and coffee (see Section V., pp. I58, I60). Coffee beans contain about I per cent., and tea leaves from about I to 5 per cent.; $3 \frac{1}{2}$ per cent. is considered an ordinary amount of caffeine in tea leaves. Tea is heated for about an hour with three or four times its weight of boiling water, and after filtration is mixed with a quantity of lime equal to that of the tea originally taken. The mixture is subsequently dried on the water-bath, extracted with boiling chloroform, and the solution subsequently recrystallized by alcohol. Theobromine, the alkaloid in cocoa, is closely related to caffeine.

Strychnine is the chief alkaloid in Nux Vomica. The finely powdered seeds are treated with lime and water, and the mixture extracted with chloroform, benzene, or amyl alcohol. 


\section{REFERENCES TO SECTION IV}

Shutt, "Infuence of Environment on the Composition of Wheat," Journ. Soc. Chem. Ind., 1909, p. 336.

Osborne, "The Vegetable Proteins." (Longmans.) mans.)

Plimmer, "The Chemical Constitution of the Proteins," p. 76. (Long-

Wood and Hardy, Proc. Roy. Soc., 1909, B. 81, 38.

Hardy, Brit. Assoc. Report, r9o9, p. 784.

Gwilym Williams, "Hydrolysis of the Soluble Protein of Swede Turnips," Journ. Agric. Science, viii., p. 182.

Thomas Thomson, "Chemistry of Vegetables," p. 799. (Baillière.)

Wallace, "Indian Agriculture," p. 235. (Oliver and Boyd.) Green.)

Thorpe, "Dictionary of Applied Chemistry," v. 627. (Longmans,

Garrad, "Tobacco Growing for Insecticidal Purposes," Journ. Board of Agriculture, 1911-12, p. 378.

"Cultivation of Tobacco for the Preparation of Fruit and Hop Washes," Journ. Board of Agriculture, 1912-13, p. 985.

Whatnough, "The Cultivation and Collection of Medicinal Plants in England," Journ. Board of Agriculture, 1914-15, p. 492. 


\section{SECTION V.-MISCELLANEOUS PLAN'T PRODUCTS}

Tea. - Tea was first introduced into Europe by the Dutch East India Company. At first it was mostly of Chinese production, but of recent years India has taken the major part of the trade. Tea thrives best in the hilly tracts, and is not usually grown in any low-lying districts, or at any pronounced altitude. It is raised from seed, and the bushes in the tea plantation are kept about four or five feet apart, so as to permit ample room for the workers to get in between for hoeing operations. The aim of the planter is to obtain a constant succession of leaf-bearing shoots, but the plant requires a period of rest. At the time of the "flush," or period of most active vegetation, the youngest leaves of each shoot are alone used in the manufacture. The bushes must on no account be allowed to produce flowers or fruit. The rainfall in tea-growing districts is invariably high, about eighty inches per annum representing a fairly satisfactory figure; long droughts are very disadvantageous. The soil must be well drained, but situations on the sides of hills are not considered very satisfactory. Light, sandy, loose, deep loams are the best type of soil, clays and shallow soils being quite unsuited. Nitrogenous manures are extremely valuable, and moderate amounts of vegetable manure desirable, but excessive vegetable matter leads to inferior grades. In Japan fish manure is used. Lime is generally considered to be very harmful except in small amounts, though in Assam lime is regarded more favourably. In Dehra Dun gypsum is used. There seems some reason to believe that tea needs an abnormal value of the ratio $\mathrm{MgO}$ : $\mathrm{CaO}$ in the soil, and requires the magnesia to be in marked 
excess. The amount of phosphoric acid and potash appears to have an important influence on the flavour. The seed is sown in nurseries, and the plants are ready for transplanting about May. Under old systems of planting the bushes were arranged almost entirely on the square, but it is becoming more popular now to plant them on the triangular system. By this arrangement a greater number of plants can be put on an acre with the same distance from bush to bush. Incessant hoeing is one of the most important parts of the cultivation. Farmyard manure is not obtainable and bullock dung is scarce and needed for food production, but some form of green manure is often used to take its place. Unpalatable oil cakes are also freely used, but there is great difficulty in obtaining sufficient suitable supplies of organic nitrogen materials, and sulphate of ammonia is used to make up for this deficiency. The tea bush will often last out from forty to sixty years, depending upon the amount of pruning. Frequent light prunings are practised and heavy prunings at intervals of every few years. The pluckings are made by pressure, and not by pulling, and the number of leaves taken off at a time will determine the quality of the tea ; the better qualities having about three leaves, and the lower qualities about five leaves. The period of plucking is most active during July, August, and September, when the result of the rains produces its maximum moisture in the soil. The tea leavis are transferred as quickly as possible to a withering house, where they are spread out in trays. This place must be kept as cool as possible, and with the greatest possible amount of ventilation, to allow rapid evaporation of water. When the leaf has become sufficiently flaccid it is carried to a rolling machine, which imitates rolling between the palms of the hands as in the original primitive Chinese system. This operation breaks up the cells of the leaf, and allows the different parts of the plant juice to come into contact with one another, so that much of the chemical change which takes place is due to the enzymes which occur in the tea itself, and as little as possible due to bacterial decomposition. The tea is then transferred to the sirocco, or drying machine, 
which usually consists of a long boiler-shaped vessel, heated by flues, with trays which are transferred from one end to the other to allow drying to take place in a steady manner. Once the tea has been thoroughly dried it is necessary that it should on no account come into contact with moist air. It is sieved into different grades as quickly as possible, and packed into lead-lined boxes. Many qualities of tea are very sensitive to damp atmosphere, so that some qualities which are known in the immediate vicinities of the teaproducing districts are quite unknown overseas, as, in spite of all efforts to obtain an air-tight tea chest, these teas deteriorate on the sea passage. Anything approaching to free admission of sea air is immediately fatal to most teas. No matter what varieties of tea are taken on board a ship in loosely closed vessels, within a day or two of leaving port they all seem to have sunk to the same low level of flavour. The greatest possible care is taken at the tea-packing stations to discover even pinpricks in the lead casings. Many of the very finest qualities of tea manufacture in China and Japan are still made by the old hand-rolling process, but modern Indian methods are becoming very common. Steaming is often an important part of the hand process, and probably prevents bacterial decomposition. The leaves produced in small cottage holdings are often put upon plates of copper and held over the fire. In some dry districts the leaves are dried by tossing them in the sun.

Cocoa contains theobromine, an alkaloid similar to that in tea, associated with a large percentage of fat.

Coffee.-Coffee is most generally raised from seed sown in nurseries, but for economy is sometimes sown directly on the ground. A few seeds are usually sown together, the weaker ones being removed. The land should be well drained, and is usually situated at moderate elevations of two thousand to five thousand feet above the sea-level, where the rainfall is between fifty and one hundred inches, and the temperature $55^{\circ}$ to $85^{\circ} \mathrm{Fahr}$. Shade is a most important point in considering coffee plantations. At least temporary shade must be provided for the seedlings. 
Small bushes are often only five feet apart, but under the tree system as much as fifteen feet is sometimes allowed. Catch crops are not infrequently grown along with the bushes. Steep hillsides are more frequently used for coffee plantations than tea plantations, but where they are used terracing is necessary. In coffee districts, the hedges may be coffee bushes, but such do not yield the best crop. Weeding is not considered an important point, at least not so important as in tea plantations. The coffee plantation usually comes into bearing about the third year and lasts for about forty years. The fruits are usually hand picked, and are frequently called cherries, whilst the seeds contained are alluded to as berries. The coffee fruit consists of an external pulp, a loose tissue called "parchment" and the silver skin, inside of which is the coffee berry. The fruits, on removal to the factory, are usually thrown into water, when the ripe cherries sink to the bottom. The ripe cherries are then removed to a pulping machine, which tears off the outer succulent part. This part is mixed up with water, and is, under the best management, carefully preserved and used as manure. After the pulp is removed, the seeds are dried. The "parchment" which surrounds the seed is usually left on, and the seeds with their "parchment" dried in the sun on large concrete floors resembling tennis courts. The machines specially designed for removing the " parchment" are usually situated near some large town, or seaport, since the weight of the "parchment" is small, and the berries carry better in their natural coat. The produce of one acre of land is about seven cwt. of prepared coffee, containing about ro or I2 per cent. of moisture. Compared to this the total weight of the wet berry, at plucking, will be about 1400 pounds, with about 270 pounds of "parchment," and yielding $\mathrm{I} 280$ pounds of wet pulp. These will contain about 15 pounds of nitrogen in the form of the berry, about 2 pounds of nitrogen in the form of "parchment," and about 3 pounds of nitrogen in the form of pulp. There will be about 3 pounds of phosphoric acid in the coffee berry, only fractions of a pound in the skin of "parchment," 
and about I pound in the flesh of pulp. There will be I6 pounds of potash in the berry, about 4 pounds in the " parchment," and about I2 pounds in the pulp. The return of the pulp does not make up for the losses, and considering the general nature of the soils on which these crops are grown, it seems highly probable that potash manure should receive more consideration. The soils on which the coffee is grown are usually fairly well supplied with phosphates. It is quite well known in common practice that nitrate of potash is an excellent manure, but owing to its expense the amount used is less than what is desirable. There is good scope here for the use of increased quantities of sulphate of ammonia. The cultivation both in Biazil and Madras are similar in this respect, that a red soil is much preferred. In Brazil steep slopes are not employed to the same extent that they are in Madras. In some kinds of treatment the "parchment" is fermented, and removed on the station, but in others both " parchment" and silver skin are treated alike, and the coffee berry is sold with both the silver skin and the "parchment" adhering to it.

Tannin.-The subject of tanning leather is treated very fully in another volume of this series (Bennett), but a brief abstract can be given here from a different point of view. The word "tannin" expresses a large number of materials, which have all the common property that they are used for manufacturing leather. The chief sources are the bark of oak and many other trees, together with myrobalans. Catechu tannin is a decomposed product of Catechin, or Khair, the extract obtained by boiling the wood of acacia catechu (mimosa catechu). As a rule more vigorous trees yield more tannin, but the character of the soil appears to be of very great importance. There are very large quantities of oak bark grown in the British Isles which are not made much use of owing to the cost of collection. This subject must be'treated as a part of the whole question of forestry of the British Isles. Reafforestation and the management of woods can only be successfully carried out if all possible sources of revenue are considered. The practical management 
of the collection of bark in the British Isles will be closely connected with the utilization of waste wood in forest problems. If it can be made profitable to bark the trees, and dispose of the bark for tannin, the waste wood can be distilled for the production of a much better quality charcoal, and in practice, therefore, the two subjects are closely connected. Calcareous soils probably produce more tannin than others, and since, in the British Isles, it is only the poorest land that can be left down to timber, this condition does not often prevail. The proportion of tannin appears to be greatest in bark removed about April or May. Characteristics of the tannins are that they reduce Fehling solution, are precipitated by basic lead acetate, give a blue-black colour with ferric chloride, and are precipitated with many bases. Phlobaphenes are the decomposed products of the tannins proper, and are nearly always contained in extracts of bark. They are red-coloured substances, and though almost insoluble in water, they dissolve in solutions of tannins. Whilst a great many of the common tannins contain the glucose grouping, such is by no means invariably the case. Gall nuts are very rich in gallo-tannic acid, and may contain as much as 50 per cent. Ordinary tannin, or gallo-tannic acid, is probably a compound containing five molecules of di-gallic acid, with one molecule of glucose. Catechin, whilst not properly tannin itself, is easily converted into catechu tannin, a change which takes place readily on heating to $120^{\circ}$, or slowly by merely boiling with water. The common extracts from the acacia or mimosa are usually mixtures of catechin and catechu tannin. The catechin itself is used medicinally in India, or as a chewing material. Tannin is abundant in the leaves, in all active growing parts and in diseased parts, like galls. Any irritation to the protoplasm appears to increase the amount of tannin. Tannin is very common in all unripe fruits, but disappears as the fruit becomes ripe.

Rubber. - Rubber, or India rubber, is the material which exudes as the result of an injury to many particular trees. Rubber is generally derived by a process of coagulation from 
such trees, creeper, shrubs, etc. The laticiferous system, which is distinct from the sap-bearing cell system, generally lies between the outer bark and cambium. By cutting through the bark into the latex cells the latex is obtained. This operation is referred to as tapping. In wild rubber $V$-shaped cuts are generally made, but in plantation rubber the trees are tapped by one central channel. The latex is collected in a cup which is fastened to the tree below the channel. In wild rubber the sticky latex is smoked over a fire from very smoky materials, which produce much creosote, tarry matter, acetic acid, etc. Only small quantities are treated at a time, and gradually a substantial piece of rubber, thirty or forty pounds weight, is produced. Plantation latex is generally coagulated by the addition of a small quantity of acetic acid, the smoking process being carried out later whilst drying. Recently some efforts have been made to produce on the estates themselves a crude pyro-ligneous acid obtained by the distillation of waste wood in a small form of retort (see p. I3I), as apparently the single application of crude pyro-ligneous acid is better than successive applications of acetic acid and smoke. The plantation rubber, being produced under at least some partial scientific treatment, is much superior to the wild rubber. The crude material often includes much resin and other vegetable matter. The impure varieties require to be cleaned in a special machine. Rubber, when stretched, does not return to its original condition, but remains stretched for some time. It does not, however, alter in volume. Rubber appears to be as incompressible as water. The fact that rubber does not return to its original length when stretched is commonly alluded to as hysteresis. The freshly cut surfaces of rubber readily adhere to one another. As rubber is, strictly speaking, an organic gel, it absorbs water freely, and may increase to an extent of twenty-five per cent. in its weight, and fifteen per cent. in its volume. Many organic liquors, like petroleum, coal tar, etc., are absorbed by rubber, and some of these make good typical colloidal solutions. 
Vulcanization.-Heat and sulphur produce a profound change in the character of rubber, known as the process of Vulcanization. The ordinary slightly vulcanized rubber corresponds to a formula of about $\left(\mathrm{C}_{10} \mathrm{H}_{16}\right)_{10} \mathrm{~S}_{2}$, but the fully vulcanized rubber, called ebonite, corresponds to about $\mathrm{C}_{10} \mathrm{H}_{16} \mathrm{~S}_{2}$. Mixing is an important part of the preparation of any rubbers for commercial purposes, absolutely pure rubber having little utility. Fillers added for some purposes are such materials as pyrites. For increasing mechanical strength zinc oxide, lime, and a few other substances are employed. Asphalte is often used to increase the resistance to water. Pigments of various types are employed to alter the colour. "Oil substitutes" are made by the action of sulphur chloride on oils (see p. r36). Vegetable oils are used for producing low-grade goods. Reclaimed or waste rubber is also much used for admixture. Rubber tubing is generally made either by pressing together the edges of sheet, or by squirting through a die. Canvas and other fabrics built up with rubber constitute an important part of the rubber industry, for all purposes where special strength is required.

Indigo.-Indigo is grown in Bengal, but is also grown very largely in other parts of India, either for local production of dyestuff, or as a green crop for increasing the amount of organic matter in the soil. It grows very freely, and does not appear to need very much manure, but the problem of the relationship of manure to indigo production has not been by any means completely settled as yet. The plant is cut before flowering, and tied up into bundles. It is carried as quickly as possible to the factories. If it is allowed to ferment, the amount of dye ultimately obtained is reduced. The bundles are filled into a large vat, pressed down by bamboos. The whole is covered with water, steeped for about ten hours, the yellow-coloured liquor thrown off, and beaten either by hand-working bamboos, or by a kind of paddle wheel. It is then carried to a boiler, where the liquor is leated. The indigo is filtered off, and the mass dried. Sometimes a further fermentation is allowed to take place 
in the cake. An acre of land produces about 60 bundles of indigo plants, each about five feet in girth, which yield about ten pounds of indigo cake. Different parts of the plant yield different quantities of indigo, the upper parts of the plant being most prolific. About one-half per cent. of crude indigo is obtained, representing about $\frac{1}{4}$ per cent. of real indigotin. The actual manufacture usually commences about the middle of June, which is a compromise, as the greatest percentage of indigotin does not correspond with the greatest yield of crop. New varieties are also being introduced, which are said to be able to yield as much as twenty-five pounds of crude indigo per acre. The processes of dyeing are described by Knecht (see p. I68).

Fruit Products.-Fruit farming is practised on a very large scale in America, where considerable areas of special land are covered with only one or two species. In Europe generally more variety is displayed. In Great Britain fruit growing is chiefly of the market garden type, although on the continent of Eur ope considerable quantities of fruit are grown on communistic lines in the villages and small towns.

The manuring of fruit trees cannot be placed on the same basis as the fertilizing of other crops. Newly planted trees should on no account receive large applications of concentrated chemical manure, and the manuring of established trees must be considered individually. The great point of variation in the requirements of fruit trees is that of the supply of nitrogen; on the other hand, phosphates are always needed. Many trees are inclined to run to wood, whilst others become stunted from bearing too heavy crops. Old or unhealthy trees receive much benefit from nitrogenous fertilizers. Grazing by poultry, etc., in the orchard is also useful. Apple trees are especially benefited by phosphates ; a dressing of basic slag in the autumn, followed by a small dressing of super-phosphate in the spring is a very excellent method of procedure. Kainit makes a very good source of potash for trees that are growing on light soils, whilst many growers apply nitrate of soda, before the flowering time. The preservation of fruit may be conducted either 
by a process of bottling, in which the fruit is placed in bottles along with water with or without sugar, and sterilized by heating with steam, or by making into jam. In the bottling method, so long as bacteria can be prevented from obtaining access to the fruit it will keep indefinitely.

Jam and similar preserves are the result of preserving fruit, even though it subsequently comes into contact with air, and, therefore, bacteria. The object aimed at in producing such a type of preserve is to obtain a solution of such strength that even the hardiest bacterial spores undergo plasmolysis. For this purpose it is not the percentage composition of the solution that is the determining point, but the molecular concentration, and 26 per cent. of glucose will be equivalent to 50 per cent. of cane sugar in producing a definite molecular concentration. During the process of boiling jam, much of the cane sugar is hydrolyzed, and the molecular concentration of the liquid is therefore almost doubled. In Japan salt is used for the preservation of fruit, and the French driedfruit industry is an important one. Fruit can be dried in the sun, or by artificial heat. The gas industry is now supplying suitable fruit-drying ovens heated by gas. Crystallized fruit is produced by soaking the fruit in a saturated solution of cane sugar. Many of these processes, however, depend upon secret details, which often involve a limited amount of fermentation to bring out special flavours. In spite of the acid flavour of many fruits, a fair proportion of sugar is always present as shown in Table 23. An apple, for example, contains more sugar than a red beetroot.

\section{TAble 23. - Sugar in Fruits.}

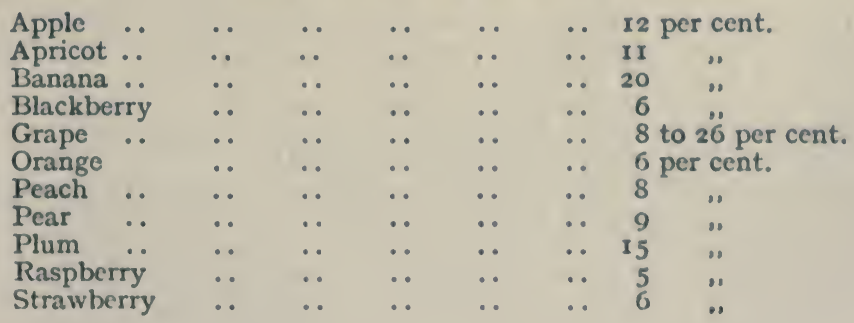


Injuries from Chemical Fumes.-Near industrial towns it not infrequently happens that fumes of sulphuric and hydrochloric acids do much harm to fruit trees. Currant bushes appear to be very susceptible to such fumes, but rhubarb is nearly as much injured and beans and potatoes in market gardens are also sometimes damaged. Whilst the removal of the acid vapours is to be desired from every point of view yet for prompt protection something can be done by sprays. At the author's suggestion experiments are being tried with a spray made from one pound of precipitated chalk in ten gallons of water ( $=\mathrm{I}$ per cent.) applied with the ordinary knapsack potato sprayer to the upper surface of the leaves of such plants as show signs of black spots. So far the experiments are very promising.

\section{REFERENCES TO SECTION $\mathrm{V}$}

Mann, "The Renovation of Deteriorated Tea," Agric. Journ. India, I906, p. 84 .

Coombs, Alcock and Sterling, "Comparative Tests with Mangrove and Wattle Barks," Journ. Soc. Chem. Ind., 1917, p. 188.

Stevens, "The Function of Litharge in the Vulcanization Process," Journ. Soc. Chem. Ind., I9I 5, p. 524.

Davies, "Hysteresis Tests for Rubber," Journ. Soc. Chem. Ind., I9I4, p. 992.

Stevens, "The Vulcanization of Rubber Agents other than Sulphur," Journ. Soc. Chem. Ind., I9I 7, pp. 107, 872 .

Eaton and Grantham, "Vulcanization Experiments on Plantation Para Rubber," Journ. Soc. Chem. Ind., I 9I 5, p. 989 ; 19I6, pp. 71 5, 1046.

Eaton and Day, "Estimation of Free and Combined Sulphur in Vulcanized Rubber, and the Rate of Combination of Sulphur with Plantation Para Rubber," Journ. Soc. Chem. Ind., I917, p. I6.

Whitby, "A Comparison of the Brazilian and Plantation Methods of preparing Para Rubber," Journ. Soc. Chem. Ind., 1916, p. 493.

Luff, "Some Aspects of the Synthesis of Caout-chouc," Journ. Soc. Chem. Ind., 1916, p. 983.

Porritt, "Some Notes on the Raw Materials used by the Rubber Manufacturer," Journ. Soc. Chem. Ind., 1916, p. 989.

Mann, "Assam Rubber," Agric. Journ. India, 1906, p. 390.

Fowler, "Bacterial and Enzyme Chemistry," p. 245. (Arnold.)

Basu, "Orange Cultivation," Agric. Journ. India, I906, p. 62; Wright,

"Hevea Braziliensis." (Maclaren.)

Joshi, "Orange Cultivation," Agric. Journ. India, 1907, p. 62.

Knecht, Rawson and Lowenthal, "A Manual of Dyeing."

Money, "Tea Cultivation." (Whittingham.)

Crowther and Ruston, "Effect upon Vegetation of Atmospheric Impurities," Journ. Agric. Science, iv., p. 25. 


\section{SECTION VI.-FERTILIZERS IN RELATION TO PLAN'T PRODUCTS}

DIFFERENT crops require different fertilizers for their development, but it must not be imagined that the fertilizers required for a particular crop are specific types of mixtures. Some general conceptions of the relationship between the fertilizers and the crops are possible, however. Proper manures for any particular crop always depend upon a very large number of circumstances, many of which may be peculiar to the district, and even to the particular field. Mixtures sold as "turnip manure," "potato manure," etc., can only give a kind of general average, and it is the business of the farmer to understand his own land, and not leave the management of it in the hands of somebody who has never seen it. No proper idea of the manure required for the crop can be obtained without a knowledge of the system of rotation adopted, and although this may also be worked down into general averages, again it is not a subject of which the farmer can leave the details to a general average of the country, but he must adopt his manure to his own particular requirements. Moreover, some land may be naturally in a high condition, whilst other land may be in a very low condition. One farmer may be justified in building up the fertility of the soil to a much higher condition, whilst another would not be justified in making any such effort. At the present time, when prices are going upwards, and while the relationship of labour to the farm is being completely altered in the British Isles, ideas which were formerly sound have become quite impracticable. The question of the markets, the supply of labour, and the rent of the land will always be in need of careful consideration. 
Contrasting the state of affairs in the British Isles, where there is a fairly conservative system in vogue, with that prevailing in the more recently developed parts of the United States, where the farmer is largely living upon capital originally stored in the soil, and also with that prevailing among some of the aboriginal tribes of India, who merely burn a patch of waste land and move on, and taking into account the relatively new lands of Australia, we may see that the system of farming will have much effect upon the suitability of fertilizers. The Western American farmer may often go on growing maize and wheat and burning the straw, and putting hardly any manure upon the land. For a time such a process may be suitable, but it cannot represent a permanent condition of agriculture. The type of pioneer farmer on the Western parts of America only represents a particular period in the opening up of the country. The American pioneer has turned out the redskin, only to be in his turn replaced by a farmer who works a mixed farm. The aboriginal Indian has originally replaced the wild animals of the forests, and he himself has been turned out by the more progressive Hindu, who to-day is being blamed for his relatively unprogressive character, and the Australian squatter, with his sheep, has turned out the aboriginal, who only hunted the kangaroo, and the squatter is feeling aggrieved because he is being replaced by the socalled "free selector." Agriculture will need to progress in all countries, and what is suitable for one step in the process is not at all suitable for another step. Further, as agriculture passes through the stage of mixed farming, it goes further, and produces the intensive farmer, who endeavours to produce the maximum amount of food from his land, and we now have to consider the question of the industrialization of agriculture, so as to induce still further improvement in the manufacture of plant products from the soil. Although it is quite impossible to set down any rigid relationship between fertilizers and plant products, it is, nevertheless, quite feasible to adopt some general principles. 


\section{The Carbohydrate Producing Crops. - Wheat is} one of the most important plants grown in all countries of advanced agriculture, as part of a system of rotation of four or more years. Wheat is particularly suited to ploughedup land which has borne grass or clover, or mixtures of the two. In such cases little fertilizer is necessary, a top dressing of sulphate of ammonia, to the extent of half a hundredweight per acre in the winter and spring, being generally considered sufficient. When many white crops are grown with a degree of frequency beyond that of once in four years, some phosphatic manures will generally be found necessary, and on the lighter soils some potash. Oats also require comparatively little manure when grown after a hay crop. Barley, when required for malting purposes, should have comparatively little nitrogenous manure, though when required for feeding purposes more may be supplied. Phosphates are particularly desirable for purposes of producing sound ripening, as alluded to below. Potatoes are grown on such a great variety of soils that it is difficult to lay down any particular rules, excepting that farmyard manure is generally desirable, although in some districts no farmyard manure is employed, potatoes being grown after about two years clover. A good deal of the advantage of using farmyard manure for potatoes is purely physical, as the potato does not develop good root system unless the soil is very open, and even actually hollow. Sulphate of ammonia is generally preferable to nitrate of soda and super-phosphate is often better than basic slag. Lime is also generally considered unsuited for potatoes. Excessive nitrogenous manure causes the potatoes to produce less starch, and more nitrogenous and fibrous tissue. In garden cultivation of potatoes working the land so as to produce a somewhat hollow structure is useful, as it induces the roots to go down after water, and leaves the soil loose for the development of the tubers. Sugar-producing crops are often more exhaustive. Swedes and mangolds require much nitrogenous as well as phosphatic manure. A standard dressing is used for mangolds at Cockle Park, containing 
eighty pounds of nitrogen, forty pounds phosphoric acid, one hundred and fifty pounds potash, and two hundred pounds common salt, a relatively somewhat expensive mixture. The root crops in general, when grown with a large amount of nitrates, especially nitrate of soda, decrease in food value, the plants being of a rather watery, poor feeding quality. Potash, which is so essential for the mangold crop, can be economized to a partial extent by the use of sodium salts. A particularly useful waste industrial product is a mixture of calcium sulphate and sodium chloride, obtained from some salt works. Where sodium chloride is desirable for cultivation, as it is in the case of mangolds, the sodium has the tendency to render the clay sticky, but an admixture of calcium sulphate overcomes this difficulty, as it prevents the formation of colloidal compounds.

The Leguminous Crops obtain much of their nitrogen from the atmosphere, and therefore do not require nitrogenous manure, excepting very small quantities to get over their early stages, when they are particularly subject to the attack of all kinds of pests. Small quantities of nitrogenous manure enable them to get out of the reach of many of their enemies at a period when their capacity for obtaining nitrogen from the air is very small indeed. They are particularly dependent upon lime, potash, and phosphoric acid. The importance of clover in the hay crop as part of the rotation has been recognized from the earliest times, the procedure being known to the Romans. This system is also adopted in tropical countries, like India, where a leguminous crop is grown either mixed with one of the millets, or as a separate part of the rotation. The increase in the nitrogen content of the soil, by the growth of clover, has been already alluded to (see p. 8I). Among the different kinds of clover, the wild white clover has been found particularly suitable for development in the pastures. Where, however, the conditions of the soil are of a rather moist character, probably the wild red clover is equally suitable. There is a great difference between growing mixed crops of herbage and growing a single crop in the ordinary way. Where 
there are many species all struggling with one another, hardy varieties are essential, hence the wild forms of the clover plant are particularly suited for development in a pasture. Seed which has been sown on well-tilled land for many generations has no necessity to struggle with other species, is weakened in the process, and is no longer able to fight for itself. There is a great difference between land which is laid up for hay and land which is down to permanent pasture. The species which will establish themselves in the two kinds of soil are not the same, and, therefore, it is not desirable that land should be sometimes cut for hay and sometimes grazed, since no permanent equilibrium would result. In the Tree Field experiment at Cockle Park the use of basic slag has completely altered the physical properties of the soil, the deep roots of the clover having altered the physical texture of the soil down to about twelve inches in depth. Somewhat similar to the action of wild white clover in the British Isles is the action of the celebrated dub grass of India, a grass which possesses a creeping stem, which opens up the soil in a more efficient way than many other forms of grass. Where land is cut for hay for any period of time, one-sided manures become impractical. Wellbalanced manuring is far more important for this purpose than for crops which are grown in a rotation. Generally speaking, it is the heavy land which should be down to grass, and such lands will not usually require much potash. The lighter lands should properly be ploughed, and not be permanently down to grass at all. Grass should only be part of the ordinary rotation on such lands, where it should be "seeds hay" for one or more years. Where land is down permanently to hay, very generous manuring is necessary. At Cockle Park, on Palace Leas Field, which has been cut for hay for over twenty years, slag has been found very profitable, but is not yielding such big crops as more mixed systems of manuring. For obtaining large crops of hay, farmyard manure is almost essential, although very fair crops have been obtained by phosphatic manures, supplemented by potassic manures. The relative feeding values of the 
hay so obtained show much variation. The amount of albuminoids in the hays so produced are much greater where phosphatic manures are applied, the best results being obtained with both phosphatic and potassic manures. Generally speaking, the hays of the higher feeding values have been those obtained by both slag and potash, even though, on the whole, the soil is towards the heavy side. Land, however, which is down to pasture, will only require much smaller dressings, and occasional quantities of lime and basic slag, giving about an average of three hundredweight of lime and one hundredweight of basic slag for each year. This is for permanent pasture, which, by rights, would only be on the heavier lands. A large amount of weeds, especially buttercup and wild geranium, are indications of excessive richness, produced by cake feeding, which has never been supported by proper supplies of phosphatic manures. For pasture lands, nitrogenous manures are generally unsatisfactory, as sufficient nitrogen is supplied by the droppings of the cattle.

Sugar Cane.-Sugar cane, like most of the sugarproducing crops, requires considerable quantities of nitrogenous fertilizers. Owing to its long period of growth, these should be of the slow-acting type. For the ratoon crops there is some difference of opinion as to whether the residues of the manuring of the previous crop can be economically replaced by more active forms of nitrogen. On the lighter soils potash is also very necessary. The chemical activities of the soil are greater in hot than in cold climates. The decay of organic matter takes place with great rapidity in hot climates, and even after ploughing-in green crops for many years the accumulation of organic matter will not reach the amount of a single green-manuring in colder climates. As carbon dioxide is produced in the soil at a greater rate than in cold climates, the general amount of carbonic acid dissolved in the soil water will be greater, in spite of the warm weather. Hence weathering of soil will take place more rapidly in tropical climates than in cold climates. 
Cotton having a somewhat shorter period of growth, and producing a seed rich in mineral matter, needs the application of larger quantities of fertilizers. Phosphates and organic nitrogen manures are very valuable for this type of crop, and sulphate of ammonia can be also used profitably here.

Tea being a perennial crop has rather more resemblance to hay than many of the other types of crop. Whilst a certain amount of nitrogenous manure is desirable, excessive amounts tend to produce an inferior quality of leaf. Some of those who experimented in the use of sulphate of ammonia obtained rather unsatisfactory results at first. The reason for this was that excessive quantities were supplied in an unsuitable manner. Where an ample supply of organic manures can be obtained, sulphate of ammonia is not so necessary, but in many situations small and cautious applications of sulphate of ammonia will probably be found useful (see Bald, p. I77).

Coffee is a somewhat exhaustive crop, and requires a fair amount of nitrogen, phosphates, and potash.

Succulent Crops.-The general effect of nitrogenous manuring is to delay the ripening of the plant, and to produce a large quantity of green material. Nitrogenous manures tend to produce large quantities of succulent matter, but do not tend to produce flowers, fruit, and seed.

These manures are, therefore, especially valuable for such crops as lettuces, cabbages, mangolds, tea, etc. The phosphatic manures are generally characterized by the production of deep roots, and it is for this reason that the shallow-rooted crops need considerable quantities of phosphates, because they have no deep root system to go after plant food, and require something to strengthen this system. Potash manure tends rather to the production of seeds and flowers, but does not help root development to any very large extent, but it has no delaying action, in the same way as the nitrogen. Development of deep roots will also depend upon the position of the water supply. Deep water will encourage deep rooting, and surface water will 
encourage surface roots. The influence of the different manures upon the composition of pasture is very marked indeed. In the experiments at Tree Field, Cockle Park, the addition of phosphatic manures not merely increased the amount of grazing, but also increased the feeding value of the grass that was cut from this pasture. The phosphoric acid was more than doubled in amount, the potash increased about 80 per cent., and the nitrogen increased about the same figure, although no nitrogen or potash was applied. The addition of lime produced comparatively little effect, either in the quality or quantity of the herbage, since this was not the material which was most urgently needed. This large increase in the percentage composition of nitrogen and potash as well as phosphoric acid has been brought about by the application of a phosphatic manure. As explained before, in the case of the hay crop more general manurial treatment is desirable, and the results are, therefore, not so striking, but the use of a manure like sulphate of ammonia does not increase the albuminoids in the hay to any appreciable extent. In the case of the swede turnip crop, manures containing little phosphates produce, on the whole, swedes which contain less sugar than those manures which are deficient in potash and nitrogen.

Food and Growth.-When very wet periods intervene there is a liability to considerable loss of nitrogen in the form of nitrates, and under these circumstances only a portion of the nitrogen supplied will go into the crop. Plants having, therefore, a short period of growth are much more likely to miss a large fraction of the fertilizing materials than those very slow growing crops that only reach maturity after many months of growth. In tropical climates, where the growth of the plant and the chemical changes in the soil are both very rapid, the manure has a greater fertilizing efficiency than in cold climates. Where soils are excessively cold, or excessively hot, full utilization of the fertilizers is impossible. Water and manure must be considered together. To some extent, a large supply of moisture, either from the sky or by means of irrigation, will make up for a deficiency in the 
supply of fertilizer supplied. In wet climates, like Ireland, unsatisfactory soils and insufficient manure may produce partially successful results, which could not possibly be imitated in a drier and colder climate. Accumulations of either acidity or alkalinity are harmful. Acidity is more frequently produced by excessive quantities of organic matter than by any accumulation of mineral acid, although the use of sulphate of ammonia in large excess may produce the latter result. Alkalinity is produced by the application of lime or by the residues of soda left from excessive applications of nitrate of soda or by natural decomposition of soda felspar in the soil. The removal of acidity is generally obtained by the use of lime, while the removal of alkalinity can be accomplished by the use of super-phosphates and gypsum. In the former case the neutralization of the acid is due to the calcium bi-carbonate formed from lime, carbon dioxide, and water. In the latter case sodium carbonate, sodium humate, or soluble sodium silicate is decomposed by calcium sulphate with the formation of neutral sodium sulphate and other harmless substances. Cultivation is one of the best means by which most is made of the fertilizing ingredients in the soil, or supplied in the form of fertilizers. Without efficient cultivation, full utilization of the fertilizers will always be impossible.

\section{REFERENCE TO SECTION VI}

"Compound Manures," Journ. Board of Agriculture, 1915-16, p. 675. p. 246 .

Clouston, "Artificial Fertilizers for Cotton," Agric. Journ. India, r9o8,

Bald, "Experiments in Manuring on a Tea Estate," Agric. Journ. India, I913, p. I57; 1914, p. 182 


\section{PART IV.-THE PRODUCTION OF MEAT}

\section{SECtion I.-MANURING FOR MEAT}

To make the most of all plant products is to make the most efficient use of agriculture. Experience in all lines of business has shown that there are certain methods common to all commercial concerns, and the plan to industrialize agriculture can only mean the adoption in agriculture of the lessons learnt in promoting efficiency in other businesses. Industrialization of agriculture is, however, no new thing; it has been done before. The large Collieries in County Durham (see p. 209), for example, employ managers and sub-managers for large estates, and many colonial concerns are also worked in the same way. Much land in the British Isles is unsuited to corn, and hence the industrial improvement of agriculture will largely turn on the improvement and development of manuring for meat and the production of cheese. One strong point in favour of industrialization is that the manager of a large concern can buy and sell on better terms than the manager of a small concern. The chief difficulty of the farm lies in the immense difference between what the consumer pays and what the farmer gets. Sometimes the farmer does not receive one-third of what the consumer pays, and the management of an industrialized farm can check this source of loss (see p. 209).

Manuring for Meat.-The change from pioneer types of agriculture to general conditions of mixed farming needs stock feeding as an essential part, since such conditions of general farming combine two entirely distinct objects, namely, stock and crop production. The amount of meat that can be produced from an area in pasture is less than that 
produced from an equal area of mixed farming, whilst that area, if entirely cultivated, would not be so productive, unless the farmyard manure could be replaced. The greatest efficiency, therefore, can be produced by combining crop and stock production. The first efforts to measure meat production in terms of fertilizers were those initiated in Tree Field, Cockle Park, by Dr. William Somerville, continued by Professor Middleton and Professor Gilchrist, and repeated in other places with similar results. The general effect of the use of basic slag on the heavy types of clay land have been to very markedly increase the amount of meat produced, as measured by means of the sheep grazing. After allowing for the cost of manure the profits are several times larger than the rental. By employing larger plots, grazed by mixed cattle and sheep, better results have been obtained. The most economical system has proved to be the application of ten hundredweight of basic slag, followed by five hundredweight every three years. Where the animal is set grazing it may be regarded as a machine for converting low-grade into high-grade food, that is, food of low value to human beings is converted into food suitable for human consumption.

In this process of conversion of crude materials into articles valuable for human purposes, considerable changes have to take place in the animal body. Grazing beasts may generally be said to be composed of about 9 per cent. bone, 40 per cent. muscle, 24 per cent. fat, and 27 per cent. blood, intestines, and other offal. Of this, the muscular part, together with the fat, forms the chief eatable material. The actual amount of human food is roughly about one-half of the total beast. At birth, young animals contain large quantities of water, about 80 to 85 per cent., but in a very fat beast the amount of water will only be about 40 per cent. If the various parts of the beast are corrected for the amount of water contained, there will be about 6 per cent. of dry material in the bones of an average farm animal, in the muscle 13 per cent., in the fat 20 per cent., leaving about 7 per cent. dry matter in the offal, the whole body containing 
about 46 per cent. of dry material, the rest being water. The fat of the animal body, like most of the other compounds of this group, is a glycerine ester, and the fatty acids are stearic, palmitic, and oleic. The fat of the animal body as separated by the butcher consists of the chemical fat, enclosed in membranes. In a fat beast the amount of membrane in the fat is comparatively small, but in a lean beast it might amount to one-quarter of the weight of the fat. Carbohydrates are only present to a very small extent. Small quantities of dextrose are always present in the blood, to the amount of about 0.1 to 0.2 per cent., any excess of carbohydrate being stored in the liver. The proteins have been fully described (see Bennett, Bibliography). During the life of the animal, the chief metabolic changes consist in the hydrolysis of the proteins, fats, and sugars, followed subsequently by their oxidation. The major part of the proteins in the animal body exist in the form of the organs, and are semi-permanent. The remaining portion is temporary, and undergoes rapid chemical changes. It is this portion which supplies the vital energy necessary to the beast. The chief effect of setting an animal to perform work is to increase the rate of chemical breakdown of the fats and carbohydrates. It is only overworking which will produce any large breakdown of the animal proteins. Stimulants, excitement, and the consumption of salt increase the amount of protein decomposed in the animal body. The heat that is lost by the animal is chiefly lost by radiation and conduction from the surface and by evaporation from lungs and skin. The evaporation from the lungs depends upon the amount of breathing, and, therefore, upon the amount of exercise.

When the proteins are broken down in the animal body, during the process of digestion, they are resolved into the corresponding amino acids. The number of these amino acids that are necessary is comparatively very limited. Most of the amino acids into which the proteins are broken down in digestion are aliphatic, some mono-carboxylic, and some di-carboxylic. Some of them are mono-amino 
acids and some di-amino. Some of them are straight, and some of them are branched. An important cyclic compound is indole, which the animal body does not seem capable of synthesizing. A common hydrolytic product of the breakdown of some proteins is tryptophane, which contains the indole ring. The proper utilization of the proteins absorbed from the food appears to depend upon minute traces of substances which are known as food hormones. Little is known about the exact character of these bodies, although some are compounds of pyridine. When tryptophane is broken up in the animal body, it is probably excreted as skatole, which is of a purgative character. One of the results of feeding excessive quantities of protein material is usually to produce a loosening effect. This is probably, at least in part, due to the excretion of superfluous quantities of bodies like skatole. Frequent mistakes in feeding cattle have been made by the use of excessive quantities of nitrogenous food, but it is not always practical to get, on economic lines, the exact mixture one requires. Maize which contains no tryptophane is known to be somewhat binding and heating in its effects. The simple amino acids, like aspartic and glutaminic acids, are produced by the hydrolysis of proteins in such large amount that relatively they are not urgently needed. Even the benzene nucleus seems to be fairly easily obtainable either synthetically or analytically. The substances constituting the nucleus of most cells contains some of the purine bases, which give rise to uric acid in man, but to allantoin in beasts. There does not, therefore, seem to be the same risk of over supply of purine bases to animals that there is to man. In estimating the feeding value of foodstuffs, it is not uncommon to differentiate between the true albuminoids and the amides, that is to say, between nitrogen precipitated by lead acetate and ammonia volatile with caustic alkali and steam, or some such similar division. Such bodies as asparagine will only yield half their nitrogen by distillation with caustic alkali and steam. Such a division, at the best, does not really answer the question we wish to ask. What we really want to know 
is the relative proportion of important ring compounds, like indole, benzene, or purine. The reason why the socalled amides have little value is that the compounds which yield ammonia on hydrolysis are plentiful in the products of hydrolysis of the protein in most cattle foods. Compounds like aspartic and glutaminic acids will probably supply twenty times as much nitrogen as substances of the tryptophane type, hence the indole groupings are comparatively scarce, and, therefore, valuable, whilst the simple amino acids, like aspartic acid, are plentiful, and, therefore, not very valuable. All these substances are probably utilized by the animal, but those that are scarce in amount are the ones whose supply we have to consider. Under special conditions even ammonium acetate has proved useful for increasing the protein laid on by beasts. Nevertheless, no very practical system has yet been discovered to obtain a clear idea of the value of the different proteins in the foods.

The metabolic changes of the fats result in hydrolysis, oxidation, and production of sugars. The sugars themselves break down with the production of carbonic acid. The proteins are chiefly concerned in the building up and repairing of the structural part of the animal body, the fats and the sugars being chiefly concerned with the production of energy.

\section{RFFERENCES TO SECTION I}

Wood and Yule, "Statistics of British Feeding Trials, and the Starch Equivalent Theory," Journ. Agric. Science, vi., p. 233.

Wood and Hill, " Skin Temperature and Fattening Capacity in Oxen," Journ. Agric. Science, vi., p. 252.

Hall, "Agriculture after the War," p. 39. (Murray.)

Armsby, "The Principles of Animal Nutrition."

Bennett, "Animal Proteids." (Bailliêre, Tindall and Cox.)

Luck, "The Elements of the Science of Nutrition." (Philadelphia.) 


\section{SEction II.-THE FOODS FED TO BEAST'S}

Water in Foods.-All foods fed to stock contain a certain amount of water in their composition. Soft turnips contain as much as 92 per cent. of water, mangolds about 86 per cent. of water, and concentrated foodstuffs, like the oil cakes and grains, contain about I 2 per cent. of water. When foods contain large quantities of water, little extra water is needed for drinking purposes, but when considerable quantities of dry food are fed, water must be used in addition. The consideration of the water supply for stock closely resembles the study of the water supply for human consumption, but a considerably lower standard may be adopted. Drainage from fields may be utilized for this purpose, but care should be taken that the water is not muddy or fouled by any trampling by the cattle themselves. A short lead of underground pipes, conveying the water from this source to a properly constructed cattle trough, will result in the supply of a considerably purer water. The mere process of running through pipes tends to purify the water, as it comes into contact with fresh air in the course of its fall. A small underground reservoir is also convenient to remove earthy matters in suspension. Where large quantities of vegetable growths occur in the drinking supply, unsatisfactory results may be observed. Each pound of dry food used needs seven pounds of water for pigs, four or six pounds for cows, or oxen, and two or three pounds for horses. Well-fed animals with a good coat usually develop excessive heat, and, therefore, do not suffer from drinking cold water. Pigs, however, being smaller animals, and being ill protected by hair, not infrequently show some good results from heating the water supply. When water, in 
combination with food, is supplied in excess, an unnecessary strain is placed upon the kidneys of the animals concerned. Increased metabolism therefore takes place, and the water actually passed has to be heated to the body temperature. Waste of energy, and therefore food, is the result of supplying unnecessary amounts of water. It is, of course, not practical to cut the water supply down below the figure which is necessary for the health and comfort of the beasts. They themselves will be the first to make objection should they be kept thirsty.

The Fat in Foods.-The foods fed to beasts generally contain fat in small quantities. The common analytical figures, which represent the total amount of material extracted from the food by the use of ether, include other substances than true oils and fats. Anything in the nature of wax or resin will also be extracted by ether. In the case of the oil seeds, the proportion of waxes and resins is relatively small, but in such food materials as hay, the proportion of ether extract which is not true fat is very considerable, and may amount to one-half. In such cases, however, the total percentage of oil is too small to make much difference, whether it is considered or not in calculating rations. The true fats are glycerine esters of some of the fatty acids (see p. I08). When fed to stock, the fat undergoes hydrolysis in the process of digestion with the production of the corresponding fatty acids and glycerine, which are absorbed and built up into the fatty tissues of the animal body. Considerable portions of the breaking-down products of the fats will be oxidized, for the purpose of producing heat, in consequence of which the properties of the fat laid on by the animal are more dependent upon the animal consuming the food than on the properties of the fat in the food consumed: For rough purposes, the food value of fats is about $2 \frac{1}{2}$ times the value of the same weight of carbohydrates.

The Nitrogenous Matter in Food. - The proteins in the foods are similar to those described in Part III., p. I47. So far as regards the more concentrated foods, the total 
nitrogen multiplied by $6 \frac{1}{1}$ is a good enough approximation, but in some of the less concentrated foods, like hay and turnips, it has been found in practice that some further information is desirable. For this reason the nitrogenous matter is commonly divided into the two groups of the "true albuminoids" and the "amides" (see p. I47). The particular amino acids required by the beasts will vary according to the needs of the animal, which will depend partly upon the species, partly upon the age, and partly upon the condition of health. Foods may not infrequently contain a few special nitrogenous matters, such as some of the nitrogenous glucosides. Some of these, of which amygdalin and linimarin may be taken as types, evolve prussic acid under certain conditions (see p. I37). Potatoes contain another special nitrogenous glucoside called solanin. Potato eyes may contain large quantities, even up to 5 per cent., but the haulms do not usually contain more than about 0.03 per cent. This substance is slightly poisonous, but the amount present is usually too small to produce any serious effect. Special foods may sometimes contain nitrates, especially crops grown under droughty conditions. Probably the nitrates themselves are not very harmful, but they usually accompany other forms of nitrogen, neither protein nor amide, and injurious results have been observed under these conditions. Mangolds, for example, are not satisfactory to feed immediately after pulling, but after an interval of storage they become riper, the nitrates, among other changes, being converted into organic nitrogen bodies, and the irritating compounds being built up into proteins. In India, juari and other fodders when cut unripe in droughts act in a similar manner. In sound food the nitrogen in the forms of true albuminoids and amides (see p. I8I) usually adds up to the total nitrogen, but in unripe root crops and leaves there are often other forms of nitrogen than these. A portion of the other forms will often be nitrates, but there are other nitrogenous compounds whose constitution is little understood. For a large number of purposes no effort is made to do more than determine the total nitrogen in the foodstuffs. 
It is only in the case of the root crops and hay that any serious error would be introduced by neglecting to measure the amides separately.

The Carbohydrates.-Sugar is much appreciated by stock, as it gives a considerable flavour to the food, and is often valuable to the farmer by inducing stock to eat otherwise not very palatable articles. The sugars found in cattle foods are cane sugar and glucose. Whilst these materials are much appreciated by stock, experimental evidence shows that their body-building power is lower than that of the starches, but as such experimental results can only be obtained by feeding sugar in large quantities, it is probable that they do not reflect the conditions of ordinary farm practice. Sugar, being instantly soluble in water, will enter the blood stream, and pass through the liver at a great rate. Very small quantities of sugar will not throw any strain upon the liver. It is, therefore, to be expected that the food value of sugar will depend largely upon the amounts fed, and that, whilst it may have a high value when the quantity is small, it may have a low value when the quantity is large. In practice, owing to the expense, large quantities of sugar are probably not fed. In the case of stock consuming large quantities of swedes, the total amount of sugar fed is very considerable. Swedes contain more than one-half of their total solid material in the form of sugar, and if these constitute half of the dry matter fed, it would mean that 25 per cent. of the ration was sugar. Experience shows that this is not economical, the inefficiency of heavy root feeding being generally attributed to the water being in excess, but it may partly be due to the sugar also being in excess. Sugar which is consumed by beasts in the form of swede turnips would not be digested at the same rate as stigar in the form of treacle, and, therefore, the strain upon the liver would not be so marked. Possibly this in the explanation why feeding sugar in the form of roots appears to be more satisfactory than feeding it in the more concentrated form.

Starch.-In the case of feeding animals there does not 
seem to be any advantage in boiling starch, the digestibilities appearing about the same in boiled and unboiled starches. The starch is converted during the process of digestion into glucose, and this passes through the liver, where it may be temporarily deposited as glycogen. Starch is particularly liable to bacterial decomposition in the intestines, probably due to the fact that its digestion is somewhat slow. Starch may, therefore, very easily suffer considerable loss.

Pectins, Mucilage, etc. - This group of carbohydrates for the most part resembles starch, but sometimes contains a proportion of pentosans. The general feeding value of the carbohydrates is the same as that of starch. Under digestive conditions these change into glucose, though some pentose is also formed.

The Fibrous Materials in Foods. -The portion of the food material which is not soluble in ether, dilute sulphuric acid, and dilute potash is considered the indigestible fibre. This material is composed largely of cellulose, together with lignin, and other materials. The ordinary analytical processes rather resemble an attempt to give a rough imitation of digestion than any effort to obtain a definite chemical subdivision. The common method of analysis will give very valuable figures representing the indigestible material, and is quite a fair approximation of the actual digestive process of the animal. Up to a certain point the ruminants require fibre in their food, as their digestive processes are adjusted to foods of this type, and if fibrous materials are withheld, the digestion is interfered with. Within limitations, therefore, fibre possesses a real value, but it is not common to consider this fact, because the fibrous foodstuffs are relatively cheap, and, therefore, the tendency is to feed rather more fibre than is absolutely necessary, but this consideration would not apply to a town cowkeeper, who has to purchase everything in the way of food, as it does to a farmer who grows his own hay. In small quantities, therefore, one must regard fibre as being useful. In large quantities it is not merely useless but highly objectionable. 
Digestion. - Attempts have been made to measure the ultimate results of the digestive processes in animals. In such experiments all the food consumed by the animal is analysed, and, in addition, all the solid excreta are analysed in the same way. The difference between the two is supposed to represent the material which has been digested. There are several errors, nevertheless, in this assumption. In the process of digestion, portions of the food are first absorbed, converted into intestinal mucus, etc., and are excreted. The ultimate gain to the animal is quite correctly represented by the difference between the two analyses named above, but a more serious error is introduced by bacterial activity. The bacteria are, all the time digestion is going on, struggling to get a share of the food. Such bacteria as oxidize the food materials will produce just the same amount of heat, as the oxidation would give under other circumstances. If the animal requires this heat there would be no loss. If the animal does not require the heat, as might be the case in hot weather, then the heat produced is not merely useless, but a nuisance. The bacteria, however, that flourish in the intestinal tracts, are for the most part of a different type, and much of their energy is devoted to the decomposition of carbohydrates with the production of marsh gas and carbon dioxide. As much as 700 litres of marsh gas from one beast in one day has been observed, which is equivalent to a waste of four pounds of carbohydrate. These carbohydrates, of course, disappear, and are considered as digested, although they have produced little heat, and no good of any kind to the animal. Such fermentive changes depend upon slow digestion, the quicker the animal can digest the food the smaller is the share available for the bacteria. As the result of such experiments, tables of digestibilities have been constructed (see Kellner). Such tables will allow one to calculate the probable amount of food actually digested by the beasts from any particular food supplied. The ordinary analysis can be carried out according to the text-books (see Bibliography), and then the digestive coefficients used to convert these figures into digestibilities. 
Such a calculation assumes that the figures apply to the particular case in question. The full table given in Kellner's work supplies a considerable amount of information which permits one to apply these values with a fair degree of certainty. There is, however, always the difference between the actual conditions prevailing and those under which the tables were deduced. A study of the tables in Kellner's work shows that in some cases very wide variations in the results were obtained. The variations compensate for one another to some slight extent. Probably the great variations that may be observed in the digestible fibre are really attributable to the fact that some of the materials which are possibly called "fibre" in the solid excreta of the beasts are really bacterial residues. The fluctuations observable in the column "total matter digested" are more valuable in assessing the probable error in these experiments. A study of the tables will convince one that the use of these tables will give a figure for the digestible ingredient per cent. which is true to two or three units, but cannot be considered as being any closer than that. In some instances it is quite obvious that Kellner himself recognized that the figures of a few experiments are not very reliable. It will be noted, on referring to p. 388 , that Kellner gives digestible coefficients for "palm nut cake" and "palm nut meal, extracted," which differ from one another to a degree which is difficult to credit ; but when he makes use of these figures for compiling the table on p. 377, he uses for calculating the digestible nutrients in those two substances, not the figures he has himself quoted, but the average of the two cases. That is to say, in calculating the digestibility of palm nut cake, he does not use his own figures but an average obtained from palm nut cake and palm nut meal. This procedure is quite legitimate, of course, but shows that Kellner did not himself attribute to his own work that degree of precision which is sometimes assumed by those who use his tables. Such apparent discrepancies in the table of digestibility of decorticated cotton seed meal, where the digestibility coefficient of the fibre varies from o to roo, though appearing very big, 
are not of great importance, because the percentage of crude fibre in this meal is very small. The fluctuations in the digestibility of the crude fibre in undecorticated cotton cake, which vary from 2 to 24 per cent., although superficially not so serious, are in practice of more importance, since the percentage of fibre in this food is about 20 per cent. In spite, however, of these apparently large discrepancies, experience has shown that feeding standards which are based ultimately on these experiments are practically sound.

During digestion, the lining of the stomach itself is protected by a supply of anti-pepsin, which is produced for this purpose. If an animal were to die suddenly during the process of digestion, the supply of this anti-pepsin would fail along with the rest of the circulation, and the lining of the stomach would be partly digested by the digestive juices. Some portion of the materials which are considered as not having been digested are really bacterial remains, which, of course, have been produced from the food by the life of bacteria, and have done no good to the animal.

\section{REFERENCES TO SECTION II}

Wanklyn, "Water Analysis." (Kegan Paul.)

Evans, "Driage," Agric. Journ. India, I9I 7, p. 234.

Leathes, "The Fats. Monograph on Biochemistry." (Longmans.)

Collins, "The Feeding of Linseed to Calves," Journ. Board of Agricul. ture, I9I 5-I6, p. I20.

Bainbridge, Collins, and Menzies, " Experiments on the Kidneys of the Frog," Proc. Roy. Soc., B., vol. 86, I0r3.

Plimmer, "The Chemical Constitution of the Proteins. Monograph of Biochemistry. (Longmans.)

Armstrong, "The Simple Carbohydrates." (Longmans.)

A. Rendall Short, "The New Physiology," p. 84. (Simpkin.)

Kellner, "The Scientific Feeding of Animals," p. 379. (Duckworth.)

Warington, "Chemistry of the Farm," p. I44. (Vinton.) 


\section{Section III.-CALORIFIC VALUE OF FOODS}

The Animal as a Heat Engine. - Just as an engine may be regarded as a means of converting the fuel supplied into work done, so a food fed to a horse may be also regarded in the same light, and the food fed to a milk-producing or fattening beast may be also regarded from the energy point of view. Energy is usually represented in terms of calories. The calorie adopted in theoretical considerations is the amount of heat necessary to raise the temperature of one gramme of water one degree Centigrade. In practical, big-scale work it is preferable to employ a unit rooo times that size, and to define this large Calorie as the amount of heat required to raise the temperature of $I$ kilogramme of water $I^{\circ}$ Cent. On such a scale, the complete combustion of earth nut oil would give 8.8 Calories, wheat gluten 5.8 Calories, starch $4^{\circ}$. Calories, and urea 2.5 Calories. In the animal body the final products of the decomposition of the foods differ from those obtained in the steel bomb used for determining heat equivalents, owing to the fact that the nitrogen is not given off as elementary nitrogen, but is given off in the form of urea. As the amount of nitrogen in urea is nearly three times as great as that in the ordinary albuminoid or protein, one part of protein may be assumed to produce one-third of a part of urea, giving a loss of $2.5 \div 3$ Calories, and, therefore, the 5.8 Calories from wheat gluten would only produce about 5 Calories in the animal body, because the fractional part would represent the loss due to producing urea instead of nitrogen. No such deduction, of course, has to be made for the carbohydrates or oils. The calories evolved in the consumption of a food, therefore, needs two deductions to be made from them. Firstly the 
deduction for indigestible material (see p. I88), and secondly, the deduction due to the urea produced in place of nitrogen. Further, during the process of digestion, bacterial fermentation produces considerable loss, and further there is a loss of energy in production, due to such operations as chewing tough fibres, intestinal movement, circulation of the blood, the action of the lungs, etc. It is, however, possible to prepare a balance-sheet of income and expenditure in terms of calories. The following represents the result of a particular experiment on a wellfed ox :-

TABLE 24.

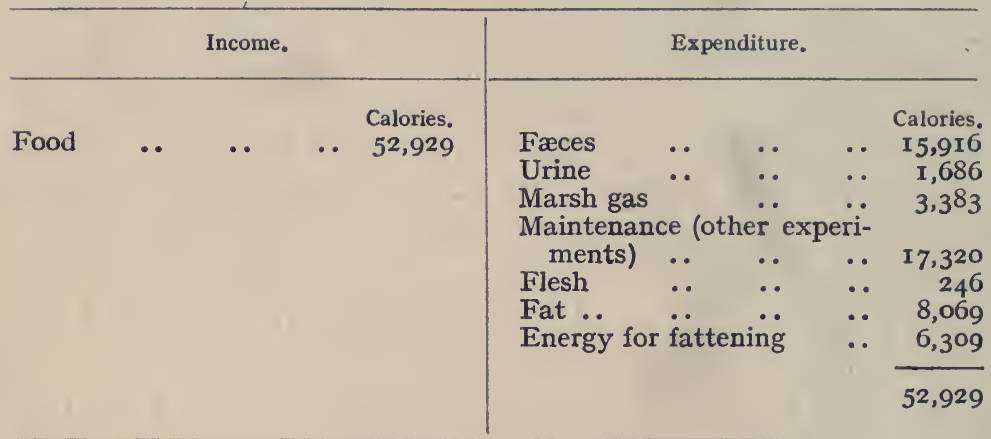

As regards the internal work in the animal, if the heat produced is really required there will be no loss due to the food itself; but if the heat produced by this work is not necessary, then such energy will have to be considered in the above table under the head of the extra energy for fattening processes. The conditions are much the same as those prevailing in a steam engine. A locomotive "standing in steam " is roughly reckoned to consume half as much coal as if it were really working, and similarly, the animal takes a good deal of food for mere maintenance, as is exhibited in the table given above. If an animal is fed with more food than is necessary for mere maintenance, a portion of the food will be used for the production of flesh and fat, but the putting on of this flesh and fat will involve a certain consumption 
of food, just in the same way as a steam engine will require a certain amount of coal to keep up the steam pressure, though doing no work, and any work required from it would necessitate a further allowance of coal, a portion only of which would be accounted for in the work done. The amount of energy required for the utilization of food materials depends upon the way in which the food materials are presented to the animal. Pure foods and sugars can be digested with the least exertion, but when these substances occur in food among hay or straw, then the animal will have to do much chewing, and other work, before the fats, carbohydrates, and proteins are acted on by the enzymes in the digestive tracts. Moreover, a far larger quantity of enzyme will have to be produced, because a great many enzymes are condensed on the surface of the fibrous matter in the alimentary tract, and most rates of decomposition depending upon enzymes are considerably retarded by the presence of cellulose in the digestive tracts ; bulky food will also need a greater amount of fluid, which has to be produced by the animal, at some expenditure of energy. Under very extreme circumstances, energy expended in the effort to digest food may exceed the energy obtained from the digested part of the food. Ruminants swallow much of their food with only partial mastication but regurgitate it, "chew the cud," and again swallow. The finely comminated material is filtered out by the third stomach and the insufficiently chewed fibres again regurgitated. In this way a ruminant can make much more effective use of fibrous food than a non-ruminant herbivorous animal. A horse is quite incapable of living upon straw alone, although an ox may just manage to keep itself alive. If, however, part of the work of digestion be done beforehand, much better results can be obtained. Kellner found that straw pulp, as used for papermaking, was far more digestible than straw itself. Of the straw pulp as much as 88 per cent. could be digested by an ox, and, after allowing for the work of digestion, the straw pulp was worth rather more than one-half its weight of starch as a food material. As, however, in the process of turning straw into paper pulp, 
about one-half the weight is removed, the ultimate advantage of such treatment is not very marked, although it does undoubtedly show that if the ox is assisted in his digestive process, a larger amount of energy will be left for him to make some good use of. In a similar way, merely chaffing straw or hay reduces the work necessary to be done by the beasts, and, therefore, a higher feeding value can be obtained. When animals are merely maintained in store condition the amount of food necessary to keep them is small, and may be of a coarse quality, since the energy expended in chewing is useful for maintaining the temperature. If, however, animals are called upon for a big output of energy, they must be fed on foods which do not involve so much internal expenditure. A horse that is doing nothing can live upon hay and grass, but the harder the work given, the greater must be the proportion of concentrated foods. If the external work is to be increased, the internal work must be decreased. The same remark applies to cattle and sheep. The relationship between the amount of calories necessary for maintenance and the live weight is not constant, but depends upon the size of the beast. Roughly speaking, the loss of heat from an animal body is proportionate to the surface, though the amount of hair and fur will effect this considerably. 'The theory, however, that the amount of heat is proportionate to the surface is surprisingly close to what is obtained in practice, although it is very easy to push the theory too far. If the "surface law" is considered, it will be seen that the weight of a beast will vary as the cube of the length, whilst the surface will vary as the square of the length. Hence, a small increment in the weight of the beast corresponds with two-thirds of that small increment in the food. 1

But as a beast grows older its digestion diminishes, and more food has to be fed to counteract the decrease in digested nutriments, hence the common rule of reckoning

1 Since

$w \sim l^{3}, f \sim s \sim l^{2} \omega w^{\frac{2}{3}}$

$$
\therefore \frac{d f}{d w}=\frac{2}{3}\left(k w^{-\frac{1}{3}}\right)
$$

where $w=$ weight, $l=$ length, $f=$ food, $s=$ surface. 
the food as proportionate to the live weight is not so very far out in practice. The surface law is more useful in comparing dissimilar animals at the same period of growth than of similar animals at different periods of growth. The surface law enables one to equate the rations of a guinea pig and a galloway, both three-quarters grown, but does not enable one to equate the rations of a calf and a Christmas fat beast.

An ox weighing 1200 lbs. needs 12,000 Calories per diem for its maintenance, whilst a sheep weighing about 100 lbs. requires 2000 Calories. Directly any work or fattening is needed, the amount of food must be increased. A horse weighing II25 lbs. required for maintenance I2,600 Calories, but when doing fairly heavy work, required more than double that quantity for its output of energy.

Many different systems have arisen to use the purely theoretical considerations given above, and apply them to the practical rule-of-thumb methods of feeding commonly adopted. These systems have followed the needs of the day. At the time when purchased cattle foods came into common use there was much more corn grown than at present. Much of this corn was grown on poor land, insufficiently manured, with a correspondingly big proportion of tail corn, or with entire crops unsuited for the production of bread. The beasts, therefore, received plenty of carbohydrates in corn and straw whilst the albuminoids were supplied by good hay, but the oil was very deficient. Hence the "oil theory" of the day. Later, as wheat was grown less and less, and as the land fell back to grass of little fattening value, the general feeding of the cows became low in albuminoids, but the increasing use of oil cakes removed the oil shortage, and the "oil theory" dropped out, and the "albuminoid theory" came in. Of recent years we have had a dearth of carbolyydrates, and the weak link in the chain has occurred at that point. But carbohydrates are too indefinite, being only a "difference figure," hence the present use of the "starch equivalent" theory.

Practical if rough ratios were studied in early resenrch in Agriculture. I awes and Gilbert, at Rothansted, deduced 
the general principles that to obtain one pound live weight increase in the weight of oxen, thirteen pounds of dry food material were necessary, whilst about nine pounds of dry food sufficed in the case of sheep, and five pounds in the case of pigs, the foods fed being of a mixed kind common to the diet used in most parts of England. The rate of increase of an animal is, however, much greater in proportion to its food in the early stages of its growth. Some of the early experiments of Lawes and Gilbert on pigs are convenient evidence on this point. In the first month they found that four pounds of food produced an increase of one pound, and in the second month it took five pounds, and in the last month of fattening it took as much as six and a quarter pounds to produce this increase. There is here no resemblance between the objects in fattening and the objects in obtaining work, since a young horse is not capable of putting forth much energy in return for its food, being occupied chiefly in growing. One method of attempting the assessment of foods is to merely take the dry matter, which is an advance on the crude methods commonly adopted. The next advance on that is to deduct the fibre or indigestible matter. A further advance is to utilize the complicated tables given by Kellner, and a further method is to deduce Kellner's starch equivalent or Hanson's milk unit. Another system consists of having standard rations, tabulated for all kinds of stock, giving so much digestible oil and carbohydrates. The latter method has the objection that it requires rather complicated sets of tables, but is perhaps the most comprehensible to the ordinary practical feeder, who finds starch equivalents rather a little beyond him. At the present time the knowledge of feeding is not sufficiently advanced to reduce the question of feeding to a scientific basis, and probably all these systems will remain in vogue. The difference between individual animals is always very great, and individuality must be allowed for, and hence great precision on the theoretical side is not of first-rate importance. In many instances, a study of Kellner's tables will show what big variations occur, 
even under carefully controlled experimental conditions. Where a large portion of the food consists of hay, large variations in digestion must be expected. Kellner found, for example, in meadow hay, that the digestibility varied from 46 to 79 per cent. The digestibility varies roughly with the fibre, and the relative food values can be obtained by the formula, $2 \frac{1}{2} \times$ oil per cent. + albuminoids per cent. + carbohydrates per cent. $-\frac{1}{2}$ fibre per cent. Kellner's tables, however, are the best available method.

The most efficient animals for converting cattle food into human food are undoubtedly those producing milk. The daily ration for a fattening beast is very similar to that for a cow giving about two gallons of milk a day. In a week a fattening beast would give perhaps about II lbs. of beef, as against I $40 \mathrm{lbs}$. of milik from a cow. As the food value of the beef is about double that of the milk, weight for weight, the advantage of milk is seen to be enormous. Even if the milk is converted into cheese, about I $4 \mathrm{lbs}$. of cheese would be obtained, and again, cheese is more than double the feeding value of beef, weight for weight, so that under any circumstances the cow is far more efficient than the bullock for converting cattle food into human food. Of course, the amount of labour involved with dairy stock is greater than that of fattening stock. The next most efficient animal to the cow is probably the pig, and sheep are generally rather better than the ox for the utilization of food material, though mixed grazing is best. On the general average, the sheep get lower quality food, and give a better return. If, however, cattle were slaughtered early, for the production of much more veal and less beef, economy would be effected in this way; but, on the other hand, the earlier slaughtered animals will need to be fed with an average higher quality food, and an average greater expenditure of labour. Poultry are not econonical converters of low-grade food into human food. It is only if they are fed to a large extent on such things as clover meal and fish meal that they can be considered as producing human food economically. Tables 25 and 26 give the data necessary to convert calories into human 
feeding equivalents. The figures in Table 2.5 refer to a man at ease, in temperate climates. A man at perfect rest, lying in bed, would only need about 2000 Calories a day; with eight hours' hard work, 3250 Calories ('Table 26); with very hard work, not actually detrimental to health, 3830 Calories.

Table 25.-Human Heat Account. At Ease.

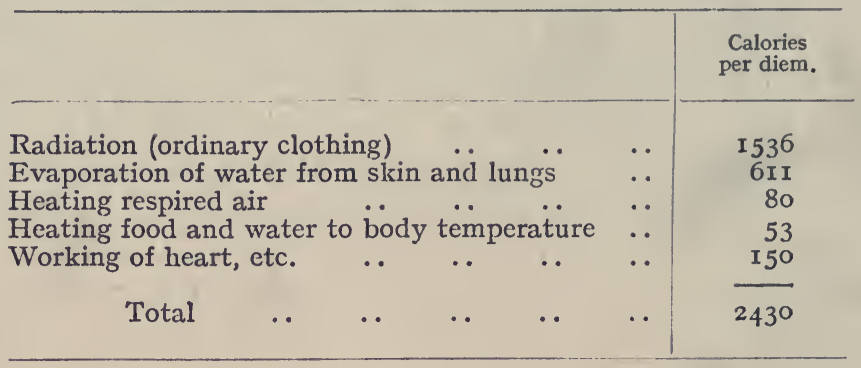

Table 26.-Daily Human Rations for Eight Hours' HARD WORK.

\begin{tabular}{|c|c|c|c|c|c|}
\hline \multirow{3}{*}{$\begin{array}{l}\text { Protein ... } \\
\text { Fats .. } \\
\text { Carbohydrates }\end{array}$} & \multirow{3}{*}{$\begin{array}{l}. \\
\cdots \\
\cdots\end{array}$} & \multirow{3}{*}{$\begin{array}{l}\cdots \\
\cdots \\
\cdots\end{array}$} & \multirow{3}{*}{$\begin{array}{c}\text { Total. } \\
\text { gm. } \\
100 \\
100 \\
500\end{array}$} & \multicolumn{2}{|c|}{ Digestible. } \\
\hline & & & & $\begin{array}{r}\text { gm. } \\
92 \\
95 \\
485\end{array}$ & $\begin{array}{c}\text { Calories. } \\
377 \\
883 \\
\text { 1988 }\end{array}$ \\
\hline & & & & & $3^{2} 4^{8}$ \\
\hline
\end{tabular}

One hundred head of population, consisting of mixed men, women, and children, may be considered as equal to seventy-seven men. One "person" needs a million Calories per annum.

\section{REFERENCES TO SECTION III}

Maidment, “ The Home Dairy," pp. I 5, 23. (Simpkin, Marshall.)

Wright, "The Composition and Nutritive Value of Mutton and Lamb," Journ. Soc. Chem. Ind., rgr6, p. 234.

"Comparative Values of Feeding Stuffs," Journ. Board of Agriculture, I9I $5-16$, p. 53 .

James Long, "Food and Fitness." (Chapman and Hall.)

Crowther, "The Feeding of Farm Stock," Journ. Board of Agriculture, I9I2-13, p. 107. 


\section{SECTION IV.-DAIRY PRODUC'TS}

MILK is composed of about 87 per cent. water, about 3.8 per cent. of fat, and 9.0 per cent. of other solids. The fat resembles ordinary animal fat, excepting that it contains rather higher proportions of butyrin and other fats containing the lower fatty acids. The chief nitrogenous material is casein, or caseinogen, which is characterized by being precipitated in acid solutions. Milk also contains a small quantity of albumen, which is precipitable by heat. Milk sugar is the only form of sugar present in milk, and on hydrolysis or digestion gives glucose and galactose. The mineral matter is fairly constant at 0.75 per cent. of which calcium phosphate, sodium chloride, and potassium chloride constitute the major part. Milk is produced directly by the breaking-down process of the tissues in the glands, and is not dependent upon the composition of the food supplied, but is maintained in molecular equilibrium with the blood. Consequently, the molecular concentration of the soluble portions is fairly constant, but a deficiency of milk sugar may be replaced by an increase in the amount of soluble salts. The freezing-point of milk is in consequence regular. There is a constant relationship between the specific gravity and the materials of which the milk is composed. This has been brought out by many authors (see Bibliography), and may be very simply expressed by the formula that the non-fatty solids $=\frac{1}{4}$ of the gravity $+\frac{1}{5}$ of the fat +0.14 , the fat being represented as percentages, and the gravity being the final figures of the specific gravity, after removing the $\mathrm{I}^{\circ} \mathrm{O}$ which is constant in all milks. The composition of the milk will vary according to many causes :- 
(I) The period of lactation. Immediately after calving, the milk is commonly called colostrum, when the composition is very abnormal. The total amount of nitrogenous material, albumen, and casein may be as high as 23 per cent., most of which is albumen, the casein being comparatively small in amount. Even the second milking on the first day shows a distinct drop in the percentage of albumen and casein, and during the first day the majority of the figures that have been obtained by the author show over ro per cent. of these two substances. The third day after calving brings the figures down to about 6 per cent. of albumen and casein. By about the seventh day the percentage of albumen and casein has fallen to 4 per cent. as against $3 \frac{1}{2}$ per cent. in ordinary milk. During the same period the milk sugar undergoes a very marked increase. On the first day the amount is only about I per cent., steadily rising until about the fifth day, when it reaches the normal figures between 4 and 5 per cent. The ash is also usually high after calving. From the second to the seventh week the greatest quantity of milk is produced, the quantity decreasing and the quality improving after that. During the last two or three weeks before going dry the milk is usually of very uncertain composition, but as the amount is very small, little trouble results.

(2) In the spring, milk is usually at its poorest, and in November at its richest. Owing to the disturbance in the times of milking which occurs on Sunday, it is not infrequently found that the Monday morning's milk is rather poor. The difference between the morning and evening milk follows a fairly regular rule, depending upon times of milking. The following formula represents the change in composition, which was obtained on an average of a very large number of experiments, $\mathrm{E}-\mathrm{M}=\frac{e}{2}-6 \cdot 2$, where $\mathrm{E}$ stands for the evening fat per cent. and $M$ for the morning fat per cent., and the $e$ stands for the interval between the evening and morning periods of milking, calculated in hours. The portions of milk first drawn may contain only I per cent. fat, whilst 
the last portions drawn may contain as much as ro per cent. fat.

(3) Some breeds, such as Jerseys, Guernseys, and Kerries, give richer milk than other breeds, such as Shorthorns and Ayrshires. Individual cows vary a great deal. Some shorthorn cows, fed and housed under the same conditions, will give $2 \frac{1}{2}$ per cent. of butter fat and 8 per cent. of non-fatty solids, whilst others of their companions will give 5 per cent. of butter fat and ro per cent. of non-fatty solids.

(4) When cows have been fed indifferently, they cannot be expected to give good quality milk, and under these circumstances improvements in the system of feeding will result in a great improvement in the quality of the milk, but there is a limit which is soon reached as regards feeding. Overfeeding does as much harm as underfeeding. With skilful management the maximum of quality and quantity can be obtained, and beyond this no one can go.

(5) When milk stands, the cream rises to the surface, especially in hot weather. In some experiments by the author, in hot weather the butter fat in the top portion of a can increased from 3 to 7 per cent. in a quarter of an hour, whilst the bottom portions decreased to 2 per cent. In cold weather, however, a variation of only I per cent. was observed in the same interval of time.

For the production of milk from plant products in the form of cattle food, it is only on the very best pastures that satisfactory results can be obtained without the use of some of the artificial foods, and during the winter-time artificial foods are always essential. Much can certainly be done to improve both pastures and hayfields, and, therefore, reduce the consumption of higher-class foods. Swedes, mangolds, or yellow turnips are fed to cows in large amounts. Grass and hay are, of course, of no direct value for human feeding, and mangolds, etc., are not worth much as human food. The cow can be regarded as a machine for the conversion of low-grade food into high-grade food, for which purpose it is more efficient than the fattening beast. Where the situation of a farm is unsuitable for the delivery of 
milk, milk can be converted into butter and cheese. The production of cream or butter fits in well with the rearing of calves, which constitutes an essential part of the milkproduction problem. It is distinctly advantageous that the calf-producing districts should be well away from the large towns, and that the milk-producing districts should be within comparatively easy reach of the large towns. The production of butter in itself is not a very economical use to put milk to, but, taken in conjunction with calf rearing, it is useful enough as a side issue. The production of cheese stands on a highei plane as regards human food production, since, for each pound of butter, at least three pounds of cheese may be obtained, but if the milk is turned into cheese, there will be less food available for rearing calves.

\section{REFERENCES TO SECTION IV}

"Clotted Cream," Journ. Board of Agriculture, I9I5-I6, p. I05.

Pegler, "The Goat as a Source of Milk," Journ. Board of Agriculture, I9I5-I6, p. 642 .

Mohan, "The Manufacture of Condensed Milk, Milk Powders, Casein, etc.," Journ. Soc. Chem. Ind., r9I5, p. Iog.

Aikman, "Milk, its Nature and Composition." (Black.)

Richmond, "Dairy Chemistry." (Griffin.)

Warington, "Chemistry of the Farm," p. 223. (Vinton.)

Maidment, "The Home Dairy," p. 34. (Simpkin, Marshall.)

Collins, "The Composition of Milk in the North of England," Journ. Soc. Chem. Ind., I904, p. 3 .

Collins, "The Natural Occurrence of Boric Acid in Milk," Univ. Dur. Phil. Soc.

Collins, "Investigations on Milk," Supplement Journ. Board of Agriculture, Nov. I9I I, p. 48 .

Leather, Analyst, igr 4 , p. 432.

"Inquiry into the Methods of sampling Milk," Journ. Board of Agriculture, I9II-I2, p. 30 .

Collins, "Difference in the Amount of Fat in Morning and Evening Milk owing to Uneven Intervals of Milking," Proc. Univ. Dur. Phil. Soc., Vol. IV. pt. I ; Journ. Board of Agriculture, I9I I-I2, p. 334.

St. John, "The Milking Machine in India," Agric. Journ. Ind., I9I7, p. 291 .

Fleischmann, "The Book of the Dairy." (Blackie.) 


\section{SECTION V.-FUTURE DEVELOPMENT}

\section{Increase of Field Fertility by Good Management.-}

$A$ very important system by which management can increase the amount of plant products is by developing the amount of grass and hay upon the heavier type of land with the aid of basic slag. When a field is under grass, and is used for grazing, the plant food contained in the grass grown is returned to the soil by the cattle grazing upon it, with only very small losses. When, however, the grass is cut for hay, and the hay fed to beasts, the manure will, for the most part, be given to the lighter lands. Hence, by means of the development of the heavy lands on a farm by basic slag, the lighter lands are indirectly benefited. On the very poor, heavy boulder clay at Cockle Park, in Northumberland, phosphatic manure has produced not merely double the quantity of hay, but in quality the hay is twice as good as it was before. In practice considerable losses occur in storing manure, but there is no reason why they should be proportionately greater with basic slag than without basic slag. If, by these means, the amount of plant food added to the lighter lands can be practically quadrupled by the proper management of the heavier lands, then a portion of the medium lands can be ploughed up and added to the arable lands of the farm. Moreover, it has been shown time after time that the replacement of grass by arable lands does not necessitate the lessening of the quantity of stock, but quite the contrary. Mr. A. D. Hall reckons that one acre of wheat will produce four quarters grain and $x_{2}$ tons straw. This food material, fed to cattle, will produce 256 lbs. of meat, or 360 gallons of milk. The same land, under grass, will produce $\mathrm{I} \frac{1}{2}$ tons of hay, giving $\mathrm{I} 20 \mathrm{lbs}$. of meat, 
or I68 gallons of milk. Both of these estimates are on the modest side. There is plenty of land which, in the past, has been under bad management and considered of very indifferent quality, which to-day, after several years of good management, has been brought up to the standard of producing 5 quarters of grain, or 2 tons of hay. Mr. A. D. Hall also shows that, on the average, the arable land of the ordinary farm is producing three times as much cattle food as the permanent grass.

Mr. T. H. Middleton considers that on grazing land the live weight increase per acre varies from $320 \mathrm{lbs}$. on exceptional pasture, down to as little as $50 \mathrm{lbs}$. on very poor grass. That is, good land: bad land::6:I. At Cockle Park, the plot grazed by sheep, where no improvement of any sort has been carried out, produces only $22 \mathrm{lbs}$. live weight increase per acre per annum (Igo6-I5) in the form of mutton, although by stocking the land with cattle and sheep, the general experience at Cockle Park has been that the mixture of stock produces almost double the amount of meat that stocking with sheep alone will do. By treatment with basic slag, this same land has been raised to the production of I30 lbs. of live weight increase per acre per annum, with sheep only, or I94 lbs. live-weight increase per acre per annum (Igo6-I5) with mixed cattle and sheep. That is, good management: bad management :: $9: \mathrm{I}$. It is, therefore, often found that the very same land may show greater variations than those of Mr. Middleton's Minimum and Maximum, according to management. There is not any reason whatever for supposing that the improvement obtained at Cockle Park might not have been made both quicker and larger if considerations of financial caution had not been necessary. Nor is there any reason for supposing that Cockle Park is exceptional.

In many districts the prevailing weather introduces many risks in corn-growing, but these districts' will often grow large quantities of green food, which can produce greater amounts of milk or beef. There are very large areas, in almost all parts of the country, where there is 
hardly any corn grown at all, but where the whole farming industry turns upon the production of milk, butter, cream, and calves. One may traval many miles in some of the fertile valleys of the Upper Tyne, and hardly ever see any arable land at all. No doubt some of the land is too far removed from the rail and road, but there is still a large area of land which could be used for the growth of, at any rate, oats and potatoes.

Greater care is needed in the storage of farmyard manure. Much loss occurs by drainage, and it is only by persistent care that this loss can be reduced (see p. 52). A greater amount of artificial manures could also often be satisfactorily employed. Even where artificial manures have been employed to a fairly large extent, it will often be found that increasing quantities will still pay. It is very rare indeed that the amounts of manuring in practice are sufficiently large to reach the stage when the "Law of Diminishing Returns " comes into force. There is probably hardly any enterprise that has been so little exploited in this country as the land, consequently it is to be expected that it will yield the best returns for labour and capital.

\section{Economic Production of Meat in Winter.-} Medium cows and bullocks may be taken to breathe out about 8 cubic feet of carbon dioxide in an hour, and it is usually considered a good allowance to give 600 cubic feet of air space and 30 square inches ventilation to each cow. Assuming a velocity of air current equal to a wind of one mile per hour through the opening, then the air in motion at the disposal of the cow during one hour is about twice the air at rest in the byre. Probably rather less than this allowance is generally given, and we may assume on a general basis that a cow has to heat up and moisten rroo cubic feet of air. If there were no loss of heat by conduction through the walls and roof, the IIoo cubic feet of air passing per hour through the ventilators, rising in temperature from $50^{\circ} \mathrm{F}$. $\left(10^{\circ} \mathrm{C}\right.$.) to $68^{\circ} \mathrm{F}$. $\left(20^{\circ} \mathrm{C}\right.$.) and evaporating the water necessary to saturate it, there would be needed 239 calories per hour. The. actual heat produced by the 
cow is I46o calories per hour. It is clear therefore that a very large fraction of the heat produced by a cow in a byre is lost by conduction of heat by the walls and roof of the byre. The byres, if better constructed, might keep the cows warm, permit of greater ventilation, and yet save food. It seems highly probable that the waste of food alluded to in Government pronouncements is often due to faulty buildings compelling the practical farmer to use more food than is strictly necessary, as judged by careful trials conducted in buildings which are more suited to the purpose than many of those that the farmer has to make the best he can of.

If we compare the type of buildings used by cattle in Great Britain with those in use in Norway, it is very obvious that the Norwegian farmer has found out by practice the necessity of saving cattle food by using warm buildings. The Norwegian cattle byre is built of wood, with double walls and an interior lining of hay. Such a structure provides better ventilation but less draughts and less loss of heat by conduction of heat through the walls, and permits winter feeding of cattle in a land where cattle food is very scarce.

It would be quite impossible to alter the cattle sheds during war time, but much might be done in small ways by the individual farmer if he could be helped by the local advisers in agricultural subjects. With the increase in the production of wheat, barley, and oats there will be an increase in the production of straw. A good use might be made of straw mats placed over ventilators, doors, roofs, etc., or any exposed parts of the buildings. Straw mats would oppose but little hindrance to ventilation. As shown above a very large fraction, say five-sixths, of the heat produced by the cow is lost through the walls, etc., of the building. It would take but little improvement to save some of this and produce more meat and milk with a saving of food.

Development of Agriculture at Home and Abroad. -Only one-fifth part of the quantity of wheat and wheat flour necessary for human consumption is produced in 
the British Isles. The great problem that is being discussed at present is how to increase the amount of wheat without decreasing the supply of meat; but by converting grass land into arable land, the amount of meat produced need not be decreased. Which farms will pay best to produce grain and which to produce meat will depend upon the situation, and there is little doubt that one of the chief difficulties in inducing changes in the general farming of the country lies in the fact that what is true for the country as a whole is not necessarily true for the individual farmer, and that, whilst it could be shown readily enough in statistics that ploughing up grass land will not decrease the meat, but will increase the bread, yet from the point of view of the farmer, there will often be a need for him to alter his system on lines which do not correspond with those of the average of the country. If, however, more wheat is grown in the British Isles, less wheat must certainly be imported. No doubt there would be a tendency to restrict those imports from foreign countries, as far as possible, but it is difficult to see how this decrease could be prevented from affecting India and the Colonies. It is, therefore, essential that each section of the British Empire should be made more self-contained.

In the statement that only one-fifth of the wheat and wheat flour are produced at home, reference, of course, is made to pre-war conditions. Probably to any such estimates at least 20 per cent, could be added by milling the wheat, so as to avoid losing the outer nutritious part of the wheat grain, and another Io per cent. could be added by the use of barley, without in any way causing inconvenience, but, on the contrary, producing a better loaf than ever. The attempts to introduce other grains have, however, in practice not proved very successful. The chief part of this difficulty lies in the fact that the starch grains of the different cereals have different temperatures of gelatinization, and, therefore, the time needed for cooking also differs. This difficulty is likely to be still further increased if potato flour is used in addition, since the gelatinizing temperature of potato 
flour and that of rice flour differ by as much as $40^{\circ}$ on the Fahrenheit scale, and it is, therefore, a practical impossibility to cook any mixture of potato flour and rice flour. Home efforts at making bread by first boiling the rice, oats, etc., independently, and then mixing with wheat flour, are satisfactory enough, because in this case each part of the flour can be given its own proper cooking (see p. II8). In any case, one may say that the 20 per cent. of home-produced wheat and wheat flour can be made up to 25 per cent. without any inconvenience or any injury. Roughly speaking, the wheat crops in 1872 were about double what they are at present. If, therefore, we could go back to that condition of affairs, the 25 per cent. could be turned into 50 per cent., that is, the British Isles could be half self-supporting in the matter of wheat. We are already more than half selfsupporting in the matter of meat, and the proposed changes in the system of agriculture should not affect these figures.

In addition to these considerations, one must remember that there are other cereals besides wheat which can be consumed. The amount of barley produced in the British Isles is not much behind the amount of wheat, and the amount of oats is very much larger. If more motor ploughing comes into force, the amount of oats necessary to maintain the plough horses on the farm would be reduced, and a larger quantity of oats rendered available for human consumption, but unless motor ploughing comes into general use the increase of horses for ploughing will result in the increase of oats consumed by plough horses. Potatoes are particularly suited for small systems of cultivation, and much help could be given by town allotments, thus relieving the farmer of a portion of his work, in growing potatoes.

Experiment has shown that, with the use of more liberal dressings of artificial manures, the fertility of the land can be well maintained, even though white crops are grown far more frequently.

Under the present condition of high prices and urgency, it would certainly be wise to employ safe manures, like basic slag, with a more lavish hand, since the conditions 
to-day are totally dissimilar to those prevailing when any agricultural experiment was instituted. In Great Britain the land has been limited in amount, and there have been very good markets, but for many years past agriculture has been severely handicapped by lack of capital and lack of labour (see p. 215).

The industrial farm is a subject of much discussion to-day. By having very large farms on the industrialized scheme the number of skilled managers would be reduced, and since highly skilled men are scarce, there would be more available. In addition, such farms would be able to attract capital and labour better than a small farm. Labour of all kinds, whether of the highest or the lowest, is always attracted to a big concern. 'There is a better security, and there is less interference with liberty. Abroad, this work has been carried out for a long time on quite a large scale. There are many very large estates in India and the Colonies which have been managed as industrial concerns, and of recent years special industries, like rubber, etc., have been added to the list. Many of these concerns are so highly industrialized that a portion of their capital is dealt in on the stock exchanges, but for the most part such concerns have been in situations where labour was plentiful, a state of affairs entirely distinct from that prevailing in the British Isles. Nevertheless, even in Great Britain, one may find many instances of highly industrialized farms. For example, some colliery companies in the northern counties manage their agricultural affairs like the rest of their business. Managers, with a scientific training, are appointed, with several assistant managers placed under them, and the men selected have, in most cases, been given an agricultural education. Unfortunately, as is inevitable, the industrialized farm does not advertise itself, and does not tell the public all about how it manages its own affairs, and it would be necessary to obtain information from the companies before any other industrialized farm could copy the methods of those farms which have been working on this scale for many years past. In a few cases, the managers of these 
industrialized farms are permitted to take one or two pupils. Common sense would suggest that other industrialized farms should secure the services of such men. Nevertheless, if industrialized farms are to be pushed at a great pace, the number of men who are qualified to take a managership will hardly be sufficient to go round. Fortunately, however, we are in a much better position to-day to develop this farm than we were twenty years ago.

There is a great contrast between the state of affairs of agriculture in the British Isles and in Germany, Holland, and Belgium during the last twenty or thirty years. It is only in Great Britain that land has been going out of cultivation. On the other hand, one may find even in Great Britain, that some farmers have put small amounts of land into cultivation. There are to be found, all over the country, what Mr. A. D. Hall very aptly calls the "little farms bitten out of the waste," for one finds them in Northumberland quite as frequently as in the south country places he mentions, and precisely as he describes it for the south, so it is true for the north, that this work has been carried out in a slow and unscientific manner. Very little attempt has been made to find out what the moors require. For the most part, they have been surrounded by walls, and stocked with cattle. Sometimes the scheme happened to succeed, and sometimes success was very small indeed. No serious attempt appears to have been made to discover whether the infertility was due to the absence of lime, or phosphoric acid, or potash, or whether it was due to bad drainage. Of recent years a few farmers have used basic slag on such moor enclosures, but their experience has been little copied by their neighbours, and the process of bringing in new land has been carried out in a very haphazard manner. In considering the question of taking up new land to-day, the high prices of labour undoubtedly is a serious difficulty. Not merely is the labour expensive, but the provision of new buildings seems almost prohibitive. On the other hand, the increase in agricultural machinery offers some compensation. Not merely does it reduce the actual cost, but it speeds up the work, and 
places the farmer in a position of less dependence upon the weather.

For an emergency, a country with a considerable quantity of arable land is much safer than a country containing much grass land. It takes, roughly, from 8 to ro lbs. of absolute food of vegetable origin to produce $I \mathrm{lb}$. of absolute food in the form of meat, though some part of that vegetable food, such as grass, is of no value for human consumption. The advantage in an emergency of having plenty of tillage is very marked, and if it had to be paid for in normal times the expense must be looked upon as an insurance against misfortune. To develop agriculture at home it is necessary to have more capital, labour, and machines. Farmyard manure must be better stored, more land should be cultivated, market gardens and allotments in the vicinity of towns must be increased. As far as possible, milk should be consumed in preference to butter, but where milk cannot be transported, owing to carriage difficulties, more attention should be paid to the production of cheese.

Increased facilities for cold storage of summer milk, summer beef, and summer mutton would enable a larger fraction of cattle food to be derived from grass.

The Financial Aspects of Agriculture. - The supply of better credit and capital to agriculture needs the earnest attention of the Government. If the Government supply a better security as regards prices, an improvement in credit will follow automatically. The mere fixing of a price here and there is no solution of the difficulty. Directly one attempts to regulate prices, one must be prepared to go in for the whole business thoroughly and systematically. The attempt to fix a maximum price for wheat, and no maximum price for meat, has the inevitable result that the farmer directs his attention more to meat than to wheat, which is directly opposite to what is wanted. A complete scheme is required before action is taken. Of course, mistakes are bound to be made at the beginning, but unnecessary changes should be avoided. It is a rather striking fact that, in spite of the great rise in the price of wheat, so little increase of 
cultivation should, as yet, have happened, but it must not be forgotten that the conduct of the business of agriculture is essentially different from the conduct of a retail shop. The shopkeeper may buy in a stock of goods one day, and sell most of them within a few days' time, and he can practically close his books as far as that transaction is concerned in a very short space of time. In agriculture, however, no business affair of any particular importance will happen in less than twelve months, and a farmer is compelled to think more in terms of four yearly rotations than in shorter periods of time. As is known, there is far too little capital, and far too little labour for the land. In I872, when the amount of land under cultivation was roughly double what it is to-day, the average price of cereals was about 40s. a bushel. In IgI6 it was just under 50s. a bushel, and in the first half of I9I7 it was about $65 \mathrm{~s}$. a bushel, yet it is taking a large expenditure of energy to induce the farmer to increase his arable land. It is, therefore, certain that price alone has very small power indeed in causing a change. Whether time and price together might not have effected a change has not yet been proved, but, considering that prices have risen steadily for many years before the war, it looks as though price and time together were not sufficiently powerful to make a change in the condition of agriculture, and that some other considerations will have to be taken into account. Nevertheless, the money side of the question is very important, and must be considered. 'There is the position of the landlord to consider. What money he has made out of the land has chiefly been by sales, and not by cultivation, and he has found all his amusement out of sport, and very little out of the cultivating side of country life. From his point of view, therefore, crop production does not appear very important, and has been neglected. The farmer has to make a living out of farming; he will not change from grass to tillage unless he sees his way to make more money out of it. Mr. A. D. Hall gives figures which suggest that grazing can produce returns to cover interest, sinking fund, profit, management, etc., of about 27 
per cent. on the capital sunk, as against I7 per cent. for arable land. That is, of course, under past prices, but obviously if prices for meat, milk, corn, and labour all go up proportionately, it does not alter the relative position of the two systems of farming. It is not so much the absolute price of wheat that is so important, as the ratio of the price of wheat to the price of meat that will determine the relative proportions of arable to grass land, and that is why the rise in price has produced so little effect. Once the State begins to interfere in the question of prices, it is almost driven into considering what kind of partial ownership of the land will have to be adopted by the State. By means of the Excess Profits Tax it is obvious that the State can assume a large share in any industry. At present the State is taxing excess profits at the rate of 80 per cent., that is to say, the State occupies the same position towards the industries of the country as the holders of founders' shares in an ordinary industrial concern do. There are many concerns where there are a small number of such founders, who in bad times receive no dividends but in good times obtain a quite disproportionate share of the profits. Under a type of taxation such as we have at present, the State is undoubtedly part owner of all the industries that are under excess profits taxation. If the Government were to put all concerns which deal in human food on the same basis, the State would become a partner in the whole of these businesses, including land, and this is a point which has to be carefully considered. The present position of affairs in the British Isles is not altogether dissimilar to the state of affairs in India, when the chaos and disorganization, resulting from the complete breakup of central authority, induced the British East India Company, and later the Crown, to adopt the attitude that the land belonged to the State, and that the State must assess what rent should be paid. When prices rise, and the supply of labour fails, and both are partly controlled by the State, then the difference between State ownership and such a condition of affairs is not, after all, a big one, and it would be wise to consider the attitude of the State 
towards a part ownership, which is already effective if unacknowledged.

The relationship between the price of grain and the wages of labour must always determine the amount of labour available upon the farm. The discussion of a possible sliding scale between prices and wages presents many difficulties, but sliding scales have been adopted in other industries which, in spite of their crudity, have been successful. The sliding scale which affects the price of gas and the dividends of shareholders has played a very useful part, though it would be difficult to conceive a more hopelessly crude basis than that on which it was founded.

The amount of capital per acre in England is about $£ 7$, whereas in former days it was much higher, $f$ Io per acre being regarded as a kind of minimum. Other parts of Western Europe have needed capital of $£ 20$ per acre. Capital, in agriculture, stands in a rather different position to what it does in many other industries, because in agriculture currency also occupies a different position. In primitive farming, currency is practically negligible. Currency to-day stands also in a peculiar position, but Great Britain has been far less affected than other countries in this respect. The currency of this country is supposed to rest on a gold basis, and nominally the treasury note is payable in gold at the Bank of England. In Germany, the gold currency is practically suspended. The German Government paper bond for ten kilogrammes of potatoes is honoured at the proper place for dealing with those articles, but the German Government paper bond for a weight of gold corresponding to twenty marks is not honoured at the place commonly dealing in gold. It would be, therefore, more correct to say that Germany has a potato currency than that she has a gold currency.

Money plays no practical part in the business of Indian agriculture. It is, therefore, perfectly possible to conduct agriculture without currency, but it would be incorrect to say that an Indian village had no capital, because it has houses, implements, etc., but such capital is very immobile. Not very many years ago the farmer in Great Britain had 
large stocks of bacon and other commodities; to-day he depends much more upon the local shops. The capital in commodities has decreased quite as strikingly as the capital acknowledged by the bank.

It is always well to look to the future, and we ourselves may be placed in straits like Germany. Should that be so, it will be worth considering whether we should not, as a nation, adopt a logical position and start an institution which would amount to a wheat bank, with wheat bonds and wheat deposits, paid for both in regard to capital and interest in terms of wheat. Perhaps some of the difficulties of supplying agriculture with the necessary capital could be overcome if we more frankly recognized that in the past agricultural capital has not altogether depended upon the acknowledged currency, but has depended very largely upon the currency of commodities and custom. To the oldfashioned British farmer capital means fat stock and a full stackyard, whilst currency means bacon and potatoes; and to the Indian villager currency is dastoor and capital a bullock. By returning to some of our old ideas we might reduce the strain resulting from the lack of that capital which has come to be defined in terms suited only to the city bank.

The Labour Question.-Many of the difficulties of agriculture during the last fifty years have arisen from the fact that the old industries which used to exist in the country have migrated to the towns. The agricultural population of a hundred years ago was not purely dependent upon agriculture, but was partly dependent upon rural industries, and it is not quite correct to say that when the rural population removed to the towns they were leaving their old employments. In part, they merely followed their old employments. To foster rural industries is part of the business of agricultural development, and the full utilization of all woods and forests is a natural part of rural economy. Whilst it is true that arable land may produce twice as much food as grass land, it would take nearly ten times as much labour to obtain such a result. And where is this labour to come from ? The 
effective labour of one man, however, shows the greatest conceivable variations. It is very difficult to represent this in any very definite terms, but Government statistics enable us to make some rough calculations, from which I should conclude that one British agricultural worker by his labours feeds about eight persons, one German agricultural worker feeds about four persons, and one Indian agricultural worker can feed no more than two, on the same scale of diet. However much doubt may be thrown upon the validity of any such crude calculations, the order of merit in the three cases is not likely to be seriously affected. The British agricultural worker has been far the most efficient. There are several reasons why such great differences are easily explainable. The "Law of Diminishing Returns" applies with quite as much force to labour as it does to fertilizers: Indeed, this is almost a self-evident proposition. A piece of land growing nothing but weeds, with its first increment of labour, will add hardly anything for human consumption, but, as more and more labour is expended upon it, its fertility rises, till, after a certain point, its limit is reached, and further labour does no good. It, therefore, is inevitable that there must be some point, in the application of labour to the soil, when a maximum of efficiency of labour is reached, after which the more work put upon the land the less is the return per unit of labour.

Further increase of arable land means taking up land which is less suited for the purpose and putting upon the land labour which is also, on the average, less suitable. It is, therefore, urgently necessary to consider how the efficiency of labour is to be increased, in order that we may counteract the inevitable tendency to produce less per head of labour employed.

As regards the quantity of labour, there is a considerable risk that England may lose her open-air population after the war, just exactly when she wants it most. The future may show that we are less prepared for peace than we were for war. Both old and new sources of labour must be directed to the land. There are a large number of men who were 
previously employed merely as routine clerks and shop assistants, who have now become accustomed to an outdoor life. They will be very unwilling to go back to indoor life, and it is now the time to consider whether their wishes and the country's needs might not be united. Much of this routine work is now being done by women who will at the end of the war be more efficient than the returned soldiers. The returned soldier will have learnt the use of spade and pick and be more suited to agriculture or forestry. Those men who are of exceptionally high mental ability, but belong to a somewhat low physical category, will all be needed for the professions, skilled trades, and directorships. In agriculture there is room for both those who have a higher degree of mental ability, and those who are chiefly physically strong. One thing is clear, we shall not need any compulsion ; we shall only need encouragement and proper facilities. Among the sources under Government control there are nearly a quarter of a million of Poor Law children, many of whom might be trained specially for the land.

As regards the efficiency of labour it should be noted that no little part of farm labour has been carried out by the "sweated labour" of the family of the small or mediumsized farmer. There are many farmers, especially at the present time, every nember of whose family is working sixteen hours a day. Such a state of affairs is not in the interests of the nation. At least one of the causes which have driven men from the land has been the excessive hours of labour. Of course, one hour of labour in the factory is not the same as one hour of labour on the field. The factory is more unhealthy, and, therefore, more exhausting. Nevertheless, however great the amelioration may be, the hours of labour on the land are not infrequently excessive, and probably do not conduce to efficiency.

As regards the economy of labour one of the great difficulties on a farm is the heavy work, due to bad roads, not merely on the horses but also on the men. These difficulties, however, are most strongly marked on farms which are largely under grass, and if the grassland is ploughed, 
the construction of roads must also be undertaken. Both the quantity and quality of labour are intimately concerned with the supply of proper accommodation. The lack of cottages is undoubtedly very serious in England, but it is not so serious in Ireland, where there are very large numbers of cottages, uninhabitable at present but possible to repair.

Undoubtedly the climate of Ireland is not that of a corngrowing country, but the use of basic slag and lime would produce more milk, butter, cheese, and calves, and thus relieve the English farmer of part of this work. As regards machinery, very great progress has already taken place in machines for reaping grain and mowing hay, and it does not seem likely that further progress can be of a very striking character. Milking machines have now reached a thoroughly practical condition, and economize labour in a very striking manner. They are not suitable for very small holders, although satisfactorily used on farms which have only twenty cows. The motor tractor and plough are not so advanced, but if men could be trained to understand both the machinery and the land, the efficiency of these machines could be enormously improved. These machines have, however, undoubtedly come to stay, and every effort should be made to overcome the difficulties in connection with them.

If we have to increase both quantity and quality of labour, we must provide a proper step to enable the labourer to rise in the world. Undoubtedly one of the great attractions of town life lies in the fact that a man has a much better chance of advancement. Whatever the merits or demerits of smallholdings may be, they provide a very valuable step between farm labourers and farmers, and even if smallholdings were not in themselves very efficient food producers, it would still be worth while pushing them, to encourage labour.

The only cure for the unsatisfactory conditions of buying and selling among smallholders seems to be some system of co-operation. It is difficult to see how any system of cooperation among smallholders can be superior to that which 
still exists in an Indian village, the inhabitants of which are more at the mercy of the money-lender and grain dealer than we would wish our smallholders to be. Nevertheless, the enormous strides which have been made in modern co-operation in India, and elsewhere, lead one to hope that much may be achieved in this direction. In considering the labour of the country, we must also consider the town labourer. At present, of our total consumption of wheat, only I9 per cent. is home grown, as against 75 per cent. of oats. Yet we each eat twice as much wheat as oats. In a similar way, we produce practically all the potatoes we eat, as against only I9 per cent. of the wheat we eat, yet our consumption per head of wheat is greater than that of potatoes. Are the town workers willing to change their diet so as to make the consumption more nearly fit the production? We ought to consume more home-grown food and less foreign-grown food. The town workers may have to learn to eat less wheat but more barley, oats, and potatoes. Undoubtedly the chief reason why our consumption of wheat is so high is because wheat lends itself to the production of bread, which can be purchased ready cooked, whilst barley, oats, and potatoes all need some treatment at home before they can be rendered fit for consumption. Germany has, to some extent, solved the problem, by producing large quantities of dried potato flour. As it happens, dried potato flour is more suited for mixing with wheat than either barley or oats for the production of bread, because potato starch gelatinizes at a temperature below that of wheat starch, whilst barley and oats require higher temperatures for cooking.

Labour must, however, be considered in relationship to other factors determining plant production. The trouble in Great Britain is that the supply of land has been in excess of the land we were willing to cultivate, and that the labour that the farmer could afford to pay for has been insufficient for that cultivation. The ratio of labour to land must be increased to obtain an increased plant production, and, since the land in the" British Isles is almost a fixed quantity, 
labour must therefore be increased, and to increase the efficiency of labour the ratio of machinery to men must be increased, and also the ratio of manure to land must be increased in order to economize labour. Where much hand work can be put into the soil, very large crops can be raised, without the expenditure of much manure. Extra labour will, indeed, cure many of the troubles which the land suffers from, although it may sometimes be more economical to employ the soil fertilizers described in the earlier parts of this volume. To increase the efficiency of labour, one must also consider the question of management. One of the difficulties in the way of industrialized farms is that the ratio of managers to men must decrease, since the employment of many managers would ruin the balance sheet. It will probably be found that there is a limit to the industrialization of agriculture, because, if you decrease the ratio of management to labour, the labour will gradually become more and more inefficient. Moreover, we require to increase the yield per acre as much as anything else. It is the last quarter of grain that takes the greatest amount of management, labour and manure to obtain. High farming is only possible with high prices, and unless the town labourer is prepared to pay these high prices, and thus support his companion on the farm, increased plant production becomes impossible. If prices are increased, wages must also be increased. If the farmer pays out much larger amounts of money for wages, he, like any other business man, must make larger profits to pay for the risks and interest on the capital that he handles, and, indeed, this is truer of the farmer than it is of many other business men, because the interval between the time when he has to pay out and the time when he begins to receive is, on the average, not less than six months.

Education.-Education concerns all classes on the land. The landowner himself must be prepared to study agriculture seriously, and to send his sons to receive an agricultural education. At present the landowner is content to send his son to the University for a purely classical style of education, whereas he should prefer his son to 
be educated in agricultural technology. He is the trustee on behalf of the nation for the proper management of the land under his control, and his sons will have ultimately to take his place, and, meanwhile, must act as his deputy. The exact type of education that is best suited to the landowner or his son has yet to be evolved, but it cannot possibly be evolved without the landowner's active participation. If the landowner's sons came to the University in sufficient numbers, the type of education given would adjust itself to suit their needs. Further, the bailiffs appointed by the landowners to manage some part of their estate should be better paid and better educated men, who would be in a position to set an example to the tenant farmers Agriculture possesses the great disadvantage of being situated away from the centres where much of the education is given, but, as it is in the interests of the country that agriculture should be advanced, it is necessary that money and energy should be expended upon rural schools, even if the expenditure appears out of proportion to the number of those attending.

It is difficult to form any very general opinion as to how much of the energy expended on agricultural education has so far produced direct results. I,ike all other teachers, those engaged in teaching agriculture cannot possibly keep in touch with the after-history of all their pupils. It is, however, possible to compile a list of those that one does keep in contact with, and assume that those one loses touch with exhibit the same ratio as those one knows. The Armstrong College Agricultural Students' Association was originally founded for the purpose of keeping in touch with old students, and the latest published proceedings of that Association show that, of the 164 members who liave kept in contact with the Association, there are 70 known to be farming, there are 9 known to have received an agricultural education and known not to be farming, there are 19 who were not educated in agricultural subjects, but who are now taking some part in assisting agriculture. The term "farming " as given in the above, includes those who are managing farms on somebody else's account as well as those who are 
actually farming with their own capital. So far, therefore, as such figures go, the energy of the teacher which has been lost is counterbalanced by the energy which goes into agriculture.

One Bachelor of Science is farming on his own account, another is managing on behalf of a big company, and as far as one can see, the education, even of the most scientific type, has produced most admirable practical results, whether expressed in terms of so much food material, or of so much cash profit.

I do not know that there can be any more complete proof that the labours of those who are engaged in teaching agricultural subjects in Armstrong College has been fully utilized for the cultivation of land and plant production. Whether the agricultural education in any other district has been equally satisfactory can only be decided by those who are intimately connected with that district, but Government statistics show that there is no reason for supposing that these results are exceptional. Agriculture has certainly used the advancements of science quite as readily as any other industry in the country, which is but faint praise.

\section{REFERENCES TO SECTION V}

Middleton, "The Farmer and Self-Improvement," Journ. Board of Agriculture, I916-I7, 户. 760 .

Hall, "Agricuiture after the War," pp. 3I, 32. (Murray.)

Middleton, "Systems of Farming and the Production of Food," Journ. Board of Agricultuve, I9I 5-16, p. 520. Press.)

Baden-Powell, "Land Systems of British India," p. 282. (Clarendon

"The Food Supply of the United Kingdom," Journ. Soc. Chem. Ind., I91 7, p. 279.

Drage, "The Imperial Organization of Trade," p. 285. (Smith.)

Hobson, "Gold Prices and Wages," p. I29. (Methuen.)

Simpson, "Co-operative Credit," Agric. Journ. India, I906, p. I3I.

Gourlay, " Co-operative Credit in Bengal," Agric. Journ. India, I906, p. $2 \mathrm{I} 7$.

Matthai, "Village Government in British India," p. I7. (Fisher Unwin.)

Green, "The Rural Industries of England," p. I46. (Marlborough.)

Report of the Board of Agriculture, Cd. 6I 5I, I9I2, p. 3I.

Smetham, "Present Conditions in Relation to Food Supplies." (Toulmin, Fishergate, Preston.)

Wood, "The National Food Supply in Peace and War." (Cambridge University Press.)

Noyes, "Financial Chapters of the War," pp. 34, 44. (Macmillan.)

Cunningham, "The Progress of Capitalism in England," p. 40. (Cambridge University Press.) 
Turnor, "The Land and the Empire." (Murray.)

"Occupations of Agricultural Students after leaving College," Journ. Board of Agriculture, I9II-12, p. 848 .

"Agricultural Credit and Co-operation," Journ. Board of Agriculture, I9I2-I9I3, p. 43.

"Improvement of Poor Hill Pasture," Journ. Board of Agriculture, 912-I3. p. 352 .

Wibberley, "Continuous Cropping," Journ. Board of Agriculture, I9I4-I9I 5, p. 8 I $_{7}$.

Clouston, "Rural Education in its Relation to Agricultural Development," Agric. Journ. India, I917, p. 216.

Allen, "The Housing of the Agricultural Labourer," Journ. Roy. Agric. Soc. Eng., 1914, p. 20.

\section{GENERAL BIBLIOGRAPHY}

[The sectional references, which form part of the Bibliography, are given at the end of each section, and may be readily traced by consulting the Contents Table, pp. xi.-xvi.]

\section{(I) ENCYCLOPADIE AND JOURNALS}

Encyclopxdia Britannica.

Wiley, "The Principles of Agricultural Analysis." (Chemical Publishing Co.)

Thorpe, " Dictionary of Applied Chemistry." (Longmans.)

Newsham, "The Horticultural Note-Book." (Crosby Lockwood.)

Primrose McConnell, "The Agricultural Note-Book. (Crosby Lockwood.)

Wright, "A Modern Encyclopædia of Agriculture." (Gresham Publishing Co.)

The Journal of the Board of Agricullure. (The Board of Agriculture and Fisheries.)

The Agricultural Journal of India. (Thacker, London; Thacker, Spink, Calcutta.)

The Journal of Agricultural Science. (Cambridge University Press.)

The Journals of the Royal Agricultural Society, the Chemical Society, and the Society of Chemical Industry.

\section{(2) AGRICULTURE}

Somerville, "Agriculture." (Williams \& Norgate.)

Shaw, "Market and Kitchen Gardening." (Crosby Lockwood.)

Hall, "An Account of the Rothamsted Expcriments." (Murray.)

Middleton, "The Recent Development of German Agriculture." [Cd. 8305.]

Fream, "Elements of Agriculture." (Murray.)

James Macdonald, "Stephen's Book of the Farm," (William Bryce.) wood.)

Voelcker, "Improvement of Indian Agriculture." (Eyre and Spottis-

Mukerji, "Handbook of Indian Agriculture." (Thacker, Spink, Calcutta.)

Geerligs, "The World's Cane Sugar Industry." (Rodger, Manchester.)

Vorhecs, "Fertilizers." (Macmillan.) 


\section{(3) CHEMISTRY}

Addyman, "Agricultural Analysis: A Manual of Quantitative Analysis." (William Bryce.)

Snyder, "Chemistry of Plant and Animal Life." (Macmillan.)

Fritsch, "The Manufacture of Chemical Manures." (Scott Greenwood.)

Cousins, "The Chemistry of the Garden." (Macmillan.)

Warington, "Chemistry of the Farm." (Vinton.)

Hopkins, "Soil Fertility and Permanent Agriculture." (Ginn.)

Hilgard, " Soils." (Macmillan.)

Collins, " Agricultural Chemistry for Indian Students." (Government of India Central Printing Office, Calcutta.)

Hall, " The Feeding of Crops and Stock." (Murray.)

Hall, "The Soil." (Murray.)

Johnson, "How Crops Grow." (Orange Judd Company.)

Russell, "Soil Conditions and Growth." (Longmans.)

Hall, "Fertilizers and Manures." (Murray.)

Cameron and Aikman, "Johnston's Elements of Agricultural Chemistry." (Blackwood.)

Johnson, "How Crops Feed." (Orange Judd Company.).

Bernard Dyer, "Fertilizers and Feeding Stuffs." (Crosby Lockwood.) Chamberlain, "Organic Agricultural Chemistry." (Macmillan.)

Tibbles, "Foods." (Baillière, Tindall \& Cox.)

Ingle, "Manual of Agricultural Chemistry." (Scott, Greenwood.)

Storer, "Agriculture in Some of its Relations with Chemistry." (Sampson Low.)

Haas and Hill, "An Introduction to the Chemistry of Plant Products." (Longmans \& Co.)

Fowler, "Bacteriological and Enzyme Chemistry." (Arnold.)

Roscoe and Schorlemmer, "Treatise on Chemistry." (Macmillan.)

Bennett, "Animal Proteids." (Baillière, Tindall \& Cox.)

\section{(4) ECONOMICS}

Theodore Morrison, "The Economic Transition in India." (Murray.) Radhakamal Mukerjee, "The Foundation of Indian Economics." (Longmans \& Co.)

Leather, "The Agricultural Ledger, I898," No. 2. (Government Printing Office, Calcutta.)

Money's Fiscal Dictionary. (Methuen.)

Fisher, "The Purchasing Power of Money." (Macmillan.)

Dunlop, "The Farm Labourer." (Unwin.) 


\section{IN DEX}

(Chief References are in heavy type.)

AByssinia, 144

Acacia, 132, 162

Acetate of lime, 125, 130

Acetates, 152

Acetic acid, 103, 125, 129, 164

Acetone, 103, 130, 136

Acetylene, 88

Acid vapours, 168

Addyman, 223

Aeration, 4

Aerobes, 50

Africa, 30

Agar, 7, 132

Aikman, 202

Air, 2, 7, 20, 82, 205

Albumen, 109, 147, 200

Albuminoids, 109, 174, 181

Albuminoid theory, 195

Alcock, 168

Alcohol, 117, 122

Aldehydes, 130

Aldo-hexose, 107

Alice springs, 69

Alkali, black, 74

Alkali cellulose, 124

Alkali, white, 74

Alkaloids, 109, 152, 156

Allantoin, 181

Allotments, 208, 211

Altitude, 65

Aluminium, 72

Alway, 84

America, 22, 77, 136, 138

Amide, 43, 109, 181

Amines, 109

Amino-acid, 34, 43, 51, 109, 149, 180

Ammonia, 13, 22, 109

Ammonia, sulphate of, 11, 89, 175

Ammonium acetate, 182

Ammonium bi-carbonate, 18

Ammonium citrate, 31

Ammonium chloride, 17

Ammonium humate, 43

Ammonium hydrogen carbonate, 18

Ammonium hydrogen sulphate, 16
Ammonium hydrogen sulphite, 16

Ammonium nitrate, 17

Amœbæ, 81, 91

Amos, 26

Amygdalin, 185

Anærobe, 50

Analysis, soil, 67, 78

Annealing, 38, 131

Anti-pepsin, 190

Apatite, 25

Apple, 104, 166, 167

Appleyard, 85

Apricot, 167

Arabic, gum, 106, 132

Arabin, 132

Arabinose, 132

Arable land, 211

Arachidic acid, 142

Archbold, 133

Argentine, 135

Arginine, 149, 151, 152

Argol, 104

Armsby, 182

Armstrong, 110, 190

Armstrong College, 221

Artichoke, 108

Ascensional currents, 65

Asparagine, 7, 109, 149, 181

Aspartic acid, 149, 151, 181, 182

Aspect, 65

Asphalte, 165

Assam, 158

Assimilation, 101, 188, 192

Atlantic, 126

Aubert, 133

Auld, 146

Australia, 30, 69, 132, 139, 170

Available lime, 28

Available nitrogen, 34, 81

Avaslable phosphorus, 28, 87

Available plant food, 4, 77

Available potash, 87

Ayrshire cow, 201

BAChelor of Science, 222

Bacteria, 23, 27, 42, 50, 81 
Baden-Powell, 222

Bailiffs, 221

Bainbridge, 190

Bajra, 125

Balance of ingredients, $8,64,83$

Bald, 177

Bales, 125, 126

Balls, 84

Baltic linseed, 135

Bamboo, 128

Banana, 167

Bank, 214, 215

Barber, 133

Bark, 162

Barley, 12, 107, 124, 148, 171, 219

Barley straw, 12

Barnes, 110

Barrages, 95

Barrenness, 93

Basic nitrogen from proteins, 149 , 152

Basic slag, 6, 16, 19, 20, 22, 27, 63, 67, $97,171,174,179,203,207,216$

Basic superphosphate, 31

Bassia, 144

Basu, 168

Bayliss, 110

Beans, 150, 168

Beaven, 110

Beccari, 147

Bedding, 46

Beech, 127

Beech leaf, 72

Beech mast, 57

Beef, 197, 204

Beer, 124

Berries, 161, 167

Berry, 133

Beet, 103, 114, 128

Beet sugar, 107, 108, 114

Bengal, 120, 126, 165

Bennett, 32, 147, 162, 182, 224

Benson, 134

Benzamido acetic acid, 44

Benzene, 181

Bitter cassava, 123

Black alkali, 74, 98

Blackberry, 167

Blackman, 92

Back cotton sced, 125

Black soils, $66,74,96$

Blackwood, 90

Blair, 146

Blast furnace dust, 38,39

Blood, 23, 57, 179

Boiled oil, 136

Boiler flue dust, 38

Bombay, 69, 132, 143

Bone, 32, 33
Bone, dissolved, 34

Bone phosphate, 32

Bone, vitriolated, 34

Borax, 138

Borday, 110

Bottomley, 59

Boulder clay, 29, 78, 97, 203

Boulton, 134

Brazil, 162

Bread, 118, 124, 147, 208, 219

Brenchley, 85, 92

Briggs, 134

British agricultural workers, 216

British East India Company, 213

British Isles, 139

Broad-casting, 6, 20, 26, 31

Broadbalk, Rothamsted, 26

Bromides, 152

Bromine, 124

Browning, 146

Brown sugar, 113

Buildings, 206, 210

Bullock Mill, 112

Bullocks, 48, 178, 192, 197

Burma, 120

Burnett's fluid, 127

Burning soil, 97

Burnt lime, 86

Butter, 102, 137, 201, 211

Buttercup, 174

Butyrin, 199

Byres, 206

Cabbages, 19, 175

Caffeine, 156

Calcareous soil, $16,72,82,163$

Calcium acetate, 103, 130

Calcium bi-carbonate, 73, 86

Calcium carbide, $21,88,91$

Calcium carbonate, $27,73,85,86$, 168

Calcium citrate, 105

Calcium cyanamide, 21

Calcium hydrate, 27, 88

Calcium oxalate, 103

Calcium oxide, 27, 72, 86

Calcium silicate, 27

Calcium sulphate, 19, 51, 74, 89, 104, 172, 177

Calcium sulphide, 87

Calcium sulphite, 91

Calcutta, 143

Calf rearing, 137, 202, 218

Calories, 191, 195, 198

Calves, 48, 136, 137, 218

Calving, 200

Cambium, 164

Cambridge coprolites, 30

Cameron, 224 
Canada, 119

Candles, 141

Cane sugar, 102, 107, 111, 174

Cannabis sativa, 127

Canvas, 106

Capillary action, 67

Capital, 210, 212, 222, 224

Caramel, 113

Carbide, calcium, 21, 88, 91

Carbohydrates, 102, 105, 111, 195

Carbon dioxide, $26,73,75,85,101$, 205

Carbon monoxide, 130

Carbonic acid, 26, 73, 75, 85, 87, 101

Carding, 125

Carey, 100

Case-hardening, 38, 131

Casein, 150, 199, 200

Caseinogen, 150, 199, 200

Casks, 20

Cassava, 123

Castor bean, 151

Castor cake, 24, 112

Catch crops, 161, 223

Catechin, 162

Catechu, 162

Cattle, 136, 142, 206

Cellulose, 105, 124, 187, 193

Centrifugal machine, 113,116

Cereal proteins, 147

Cereals, 11, 40, 117, 118, 120, 124

Cesspools, 54

Ceylon, 144

Chadwin, 133

Chalk, 8, 24, 73, 85, 86, 88, 98, 103, 168

Chamberlain, 224

Chance mud, 87

Charcoal, 125, 129

Cheese, 107, 197, 202, 211, 218

Chemical fumes, 168

Chemistry, soil, 70

Chewing, 192, 193

Children, 198

Chili, 18

China, 120, 132, 152, 158, 160

Chlorides, 17, 108, 152, 168

Chlorine, 108, 124

Church, 133

Cider, 104

Cinchona, 153

Cinchonin, 154

Citric acid, 28, 71, 77, 104

Classification of fertilizers, 3

Clay, $16,19,21,40,55,64,70,82$, $96,97,203$

Clerks, 217

Clifford, 58

Close packing, 62

Clot, Blood, 23
Clouds, 65

Clouston, 177, 223

Clover meal, 107

Clovers, 25, 82, 98, 171, 172

Coagulation, clay, 87

Coal, 11, 75

Cockle Park, 25, 29, 63, 66, 70, 81, $171,173,179,203,204$

Coconuts, 131, 139

Coffee, 19, 156, 160, 175

Coir, 140

Coke, 21

Coke ovens, 11

Collins, 9

Colloidal clay, 89

Colloids, 19, 44, 62, 64, 94, 106, 164, 172

Colonies, 207, 209

Colophony, 145

Colostrum, 200

Colour of soils, 66

Colza, 143

Compact soils, 66

Composts, 57

Compound manures, $32,40,155$

Conduction of heat, 66

Conifers, 127, 131

Cooking starch, 207

Coombes, malt, 124

Coombs, 168

Copeland, 146

Copper, 104, 152

Copper hydrate, 109

Copper sulphate, 91

Copra, 140

Corn manure, 40

Cornwall, 132

Corylin, 152

Cotton, 105, 125, 137, 175

Cotton rags, 128

Cotton-wool, 105

Countess Cinchon, 153

Cousins, 224

Coventry, 134

Cows, 48, 183, 197, 201, 205

Cracks in soil, 70

Cranfield, 39

Cream, 201

Credit, 210

Creosote, 127, 128, 164

Crookes, 20

Cross, 110, 134,

Crowther, 146, 168, 198

Crumb structure, 62

Crystallized fruit, 167

Cud, 193

Culms, 124

Cuprammonium hydroxide, 105

Cunningham, 222 
Curd, 132, 199

Currant, 168

Currency, 214

Custom, 215

Cyanamide, calcium, 10, 21

Cyanides, 38, 88, 123, 136

Cyanogenetic glucoside, 123, 136

Cystine, 151

\section{DAIRY, 197, 199}

Dams, 95

Dark soils, 66

Dastoor, 215

Date palm, 116

Davies, 168

Davis, 134

Davy, Humphrey, 1, 9

Day, 168

Decorticated rice, 121

Decorticated cotton cake, 138

Deep rooting, 175

Deep tillage, 69

Deflocculation of clay, 87

Dehra Dun, 158

Delay of ripening. 10

Deliquescence of fertilizers, 17, 19, 20

Den, 30

Denbigh, 133

Denitrification, 51, 82

Depth of penetration of manures, 7,34

Destructivedistillation, $125,129,147$

Development of Jeaf, 17

Dextrin, 106

Dextrose, 106, 180

Diabetes, 150

Diastase, 106, 124

Dibdin, 58

Di-calcium phosphate, 25, 31, 32

Di-cyanamide, 22

Diffusion process, 114

Di-gallic acid, 163

Digestion, 188, 194

Dihydroxy succinic acid, 104

Diminishing returns, 83, 205, 216

Di-saccharose, 107, 111

Disease, 27, 73

Dissolved bones, 34

Distillation, destructive, 125, 129 , 147

Distribution of fertilizers, $5,7,25$

Distributors, manure, 25

Dowling, 133

Drage, 222

Drainage, $16,17,19,21,45,47,52$, $68,95,183,205$

Draughts, 206

Dried fruit, 167
Driers for oil, 103, 136, 143

Drill, 6, 21

Drinking coconuts, 139

Drought, 7, 15, 21, 35, 95, 109, 110

Drying oil, 108, 136, 138, 143, 146

Dry lands, 94

Dub grass, 173

Dung, 46, 192, 205

Dunlop, 224

Dunstan, 146

Durham, 73, 178

Dyer, 36, 77, 85, 104, 110, 133, 224

Dyes, 125, 165

\section{EARTH closet, 54}

Earth nut, 142, 191

Earths, nitre, 21

Earthworms, 5, 24

East Indian rape, 143

Eaton, 168

Ebonite, 165

Economy of water, 95, 101, 110

Edestin, 151

Education, 220

Efficiency of labour, 216

Egypt, 21, 118, 125, 138

Electric carbon filament, 106

Electricity, 89, 92

Elementary nitrogen, 51, 82, 191

Ellmore, 134

Embryo, 149

Emulsion, 128

Enclosure, moor, 98, 210

Enzyme, 106, 136, 137, 159, 193

Errors of experiment, 99

Essential oils, 109, 145

Ester, 108

Evans, 190

Evaporation, 69, 95, 161, 180, 198

Evolution of nitrogen, 51, 82

Excreta, 47, 54, 188, 192

Exhausted soil, 3, 14, 86, 93

Eyre, 146

\section{FABRIC, 125}

Fæces, 47, 54, 188, 192

Farmyard manure, 42, 52, 122, 173, 179

Fashions in farming, 83, 89

Fat stock, 183, 215

Fats, 22, 33, 102, 108, 135, 179, 184, 192

Fattening, 192, 196

Fatty acids, 102, 108, 141

Faulty buildings, 206, 210

Feather waste, 23

Febrifuge, 154

Feed meal, gluten, 120

Fehling's solution, 107, 108 
Felling timber, 127

Fens, 96, 97

Fenton, 110

Fermentation, 50, 103, 117, 124, 192

Ferozepore, 143

Ferric hydrate, 26, 66, 71, 75

Ferro cyanide, 88

Fertility, 2, 3, 67, 93, 169

Fertilizers, 2, 10, 73, 86, 169

Furfuraldehyde, 105

Furfuroids, 106

Fibres, 106, 125, 126

Filter paper, 105

Financial aspect, 211

Fine grinding, 6, 25, 41

Finger and toe, 32, 73

Fish, 22, 24, 158, 197

Fisher, 146, 224, 197

Fixation of atmospheric nitrogen, $11,51,81,82,176,203$

Fixation of fertilizer, 13

Flax, 126, 128, 135

Flesh, 185, 192, 199

Fletcher, 134

Flocculation, clay, 19, 74, 89, 96

Florida phosphate, 30

Flour, 118, 122, 147, 207, 219

Flour, potato, 122, 219

Fluff, cotton, 125

Fluorine, 25, 33

Flush of tea, 158

Fog, 65

Foreign-grown food, 219

Forestry, 127, 215

Formaldehyde, 101

Formic acid, 102

Forster, 110

Fowler, 58, 146, 168, 224

Fream, 84, 223

Free selector, 170

Fritsch, 224

Frost, 91

Fructose, 107, 108

Fruit, 10, 163, 166, 175

Fruit sugar, 107

Fungicides, 91

Galactose, 107, 108, 132, 199

Gall nuts, 163

Gallo-tannic acid, 163

Gardens, 17, 54, 66, 122, 208, 211

Garden soils, 26, 54, 66

Garrad, 157

Gas, wood, 129

Gas lime, 88, 91, 97

Gas works, 11, 18

Gases occluded by soils, 81

Geerligs, 223
Gel, 7, 44, 164

Gelatine, 7, 32, 33

Gelatinization, starch, 106, 118, 207. 219

Gelose, 132

Geranium, wild, 174

Germany, 37, 93, 214, 215

Germicides, 91

Germination of seeds, 38,96

Gilbert, 1, 76, 85, 195

Gilchrist, 85, 179

Gingelly, 144

Gliadin, 147, 149

Globulin, 150

Glucose, 103, 106, 108, 123, 163, $167,186,199$

Glucoside, 145, 185

Glucosides, cyanogenetic, 123, 136

Glucosides, nitrogenous, 10?, 185

Glue, 32

Glutaminic acid, 149, 151, 181

Gluten, 147

Gluten feed meal, 119, 120

Glutenin, 147, 149

Glycerine, 108, 141, 180, 184

Glycogen, 187

Goat, 202

Gold currency, 214

Golding, 58

Golf-green worms, 24

Gooseberries, 17, 19, 104

Gorham, 100

Gourlay, 222

Gram (pea), 125

Grandeau, 76

Grantham, 168

Grape sugar, 106

Grapes, 104, 167

Graphite, 21

Grass, 124, 128, 173, 201, 203

Grass land, 29, 30, 63, 81, 179, 211

Grass manure, 25, 40, 176

Gravel soil, 24, 66, 94, 160

Gravity, specific, 64, 199

Grazing, 120, 179

Green, 222

Green crop, 19, 119, 168, 175

Greenhouses, 65, 90

Greenwich, 67

Gregory, 153

Grigioni, 24

Guano, 22, 35

Guernsey, cow, 201

Gum, 106, 131, 132

Guzerat, 143

Gwilym Williams, 157

Gypsum, 19, 51, 74, 88, 96, 104, 172,177 
HAAS, 110, 133, 224

Hall, 9, 36, 84, 85, 133, 182, 203 , $210,212,222,223$

Hanley, 92

Hanson, 196

Hard pan, 19, 63

Hard woods, 127

Hard work rations, 198

Hardy, 157

Harrowing, 66

Haulms, 185

Hay, 9, 12, 19, 124, 136, 171, 173, 201

Haynes, 134

Haze] nuts, 152

Heat, soil, 65,90

Heather, 98

Heavy soils, $16,19,21,40,55,64$, $70,82,96,97,203$

Hedge clippings, 57

Heidstam, 134

Hemp, 127, 128, 145, 151

Hendrick, 24, 59, 133

Henry, 146

Herring waste, 22

Hexoses, 106

Higgins, 116, 133

High farming, 220

High prices, 220

Hilgard, 84, 100, 224

Hill, 110, 133, 182, 224

Himalayan rivers, 95

Hindu cultivation, 170

Hippuric acid, 44

Histidine, 149, 152

Hobsbaum, 24

Hobson, 222

Hoeing, 66, 116

Holland soil, 93

Hollow soil, 171

Home-grown food, 219

Honey, 107

Hoofs, 23

Hoosfield, Rothamsted, 26

Hop farmers, 24

Hopkins, 224

Hordein, 149

Hormones, 181

Horns, 23

Horse feeding, 48, 50, 183, 193

Howard, 100, 133

Hughes, 36

Human heat, 198

Human rations, 198

Humic acid, 43, 76

Humogen, 58

Humphry Davy, 1, 9

Humus, 16, 19, 21, 28, 42, 63, 70, 76, 97

Hutchinson, 81, 92
Hydraulic press, 125, 135

Hydrochloric acid, 32, 71, 168

Hydrofluoric acid, 71

Hydrolysis, 124, 137, 143

Hydroxy propionic acid, 103

Hydroxy succinic acid, 104

Hyland, 146

Hysteresis, 164

INDIA, 21, 47, 70, 94, 110, 111, 120 , $125,126,132,135,138,143,152$,

$158,165,173,207,209,213$

Indian village, 214,219

Indiarubber, 163

Indigo, 165

Indigotin, 166

Indo-Gangetic alluvium, 78

Indole, 181

Industrial farm, 178, 209, 210

Infertile soil, 14, 97

Ingle, 224

Insecticides, 154

Insoluble albuminoids, 7, 43, 147

Insoluble nitrogen, $\mathbf{3 4}$

Insoluble phosphates, 30,34

Intestinal mucus, 188

Intestines, 179, 184, 188, 193

Iodine, $20,106,108,152$

Iodine value of oils, 136

Ireland, 97, 126, 177, 218

Irish linen, 126

Iron, 27, 66, 71, 74

Irrigation, 66, 67, 94, 111, 118, 150

Island, Sea, 125

Italy, 139

JAM, 117, 167

Japan, 120, 132, 138,151,158, 160,167

Japanese larch, 127

Jatindra Nath Sen, 36

Jersey cow, 201

Jesuit's bark, 153

Jethro Tull, 1

Johnson, 224

Jones, 36

Jorgensen, 90, 92, 110

Joshi, 168

Juari, 125, 185

Jute, 126

KAINIT, 37

Kangaroo, 170

Keen, 84

Kellner, 189, 196, 193, 196

Kent hops, 24

Kernels, rice, 121

Kerry cow, 201

Kessel Myer, 147

Keto-hexose, 107 
Kettle, Linseed, 135

Khair, 162

Kidneys, 184

Klason, 134

Knapsack sprayer, 168

Knecht, 168

LABOUR, 209, 210, 212, 215

Lack of balance in soil, $8,64,83$

Lactation, 200

Lactic acid, 103

Lactones, 103

Lactose, 107, 199

Lævulose, 107

Lamb, 24

Landowners, 220

Latex, 164

Laticiferous system, 164

Lawes, 1, 76, 85, 195

Lawns, 145

Lead, 136, 152

Lead acetate, 109, 152

Lead-lined tea chests, 160

Leaf mould, 57

Leake, 84

Leather (tanned), 35, 162

Leather, J. W., 85, 100, 133, 202, 224

Leathes, 145,190

Leaves as litter, 45

Leblanc, 87

Leguminous crops, 11, 27, 82, 150, 172

Leguminous proteins, 150

Lemons, 104

Lemstrồm, 90, 92

Lentils, 150

Lettuces, 175

Light soils, 40, 55

Lignin, 106, 127, 129, 187

Lime, 8, 14, 16, 19, $2123,27,28$, $72,82,86,97,113,153,165,177$, 218

Lime, gas, 88

Lime-magnesia ratio, 9,74

Lime, nitrate of, 20

Limestone, 86

Linen, 126, 128, 135

Linimarin, 123, 136, 185

Linoleic acid, 136

Linseed, 24, 123, 126, 135, 143

Linseed cake, $7,136,183$

Linsecd mash, 137

Litter, 44, 50

Little farms, 209

Live weight increase, 204

Lloyd, 146

Loaf, 118, 124, 147, 207, 219

Loam, 29, 78

Lodging of crops, 10,111
Loewenthal, 168

Logs, 127

Long, 198

Loose packing in soil, 62

Lubricating oil, 144

Luff, 168

Luxmore, 78, 84

Lying in bed, calories, 198

Lysine, 149, 151

Macdonald, James, 223

Machinery, 210, 218

Mackenzie, 133

Maclennan, 92

Madras, 78, 95, 142, 143, 162

Magnesia, 8, 27, 33, 73, \$6, 97, 158

Maidment, 146, 198, 202

Maintenance, 192, 198

Maize, 119, 122, 148, 181

Maize germ meal, 119

Malic acid, 104

Malonic acid, 104

Malt, 106, 124, 171

Malto-dextrin, 106

Maltose, 106, 107

Managers, farm, 209

Manchuria, 138

Manganese, 8, 27, 72, 135

Mangel wurzel, 12, 114, 116, 171, $175,185,201$

Manitoba flour, 150

Mann, 168

'Manure heap, 43, 48

Margarine, 141, 142, 144

Market garden, 17, 66, 122, 166, 168,211

Marl, 97

Marseilles oil extraction, 142, 144

Marsh gas, 188, 192

Martineau, 133

Maryland soil, 93

Matthai, 222

Mauritius sugar, 111

Meadow hay, 12, 19, 124, 136, 173, $193,201,222$

Meal, gluten feed, 120

Meal, maize germ, 119

Meat, waste, 24, 178, 206, 211, 213

Mechanical pulp, 128

Mechanical analysis of soil, 67

Menzies, 190

Mercerized cotton, 125

Meshes of sieves, $6,25,118$

Methyl alcohol, 130

Mica, 144

Micro-coccus, 42

Middleton, 179, 204, 222, 223

Milk, 103, 105, 107, 197, 199, 206, 211,213 
Milking machines, 218

Milk sugar, 107, 199

Miller, 85

Millets, 125

Millipedes, 91

Mimosa, 163

Mineral phosphate, 30

Mitchell, 146

Mixed farming, 178

Mixed fertilizer, 40

Mixed stock, 204

Mohan, 202

Moist air, 19, 205

Moisture, 19, 23, 65, 82

Molasses, 113

Money. (author), 168, 224

Money (cash), 212, 220

Moneylenders, 219

Mono-calcium phosphate, 25, 31

Mono-saccharose, 106

Moors, 98, 210

Mordanting, 103

Morphine, 153

Morrel, 146

Morrison, 224

Motor ploughing, 208, 218

Mowha, 24, 144

Mowra, 144

Mucilage, 131, 136, 187

Mukerjee, 133, 224

Mulch, 66, 68, 95, 111

Muriate of ammonia, 17

Muscle, 179

Mustard oil, 143

Myer, Kessel, 147

Myrobalan, 162

NAKED cotton seed, 125

Naphthalene, 91

Narcotine, 153

New land, 210

Newsham, 223

Nicol prisms, 106

Nicotine, 154

Niger seed, 144

Night soil, 54

Nile, 94, 95

Nitrate, ammonium, 17

Nitrate of lime, 17, 20

Nitrate of potash, 21

Nitrate of soda, 17, 18, 20, 21, 23, $63,87,110,171$

Nitrate, soil, 51, 76, 80, 82, 109

Nitre earth, 21

Nitre well, 21

Nitric acid, 18, 21, 76

Nitrification, 16, 22, 27, 51, 80, 82, 87

Nitrifying bacteria, 23, 91

Nitrite, 51, 82
Nitrogen, 10, 21, 22, 23, 47

Nitrogen, available, 13, 23, 87

Nitrogen, elementary, 51, 52

Nitrogen fixation, 51, 81, 82

Nitrogen in feeding, 48

Nitrogen in soil, 81

Nitrogen in unripe fodder, 110

Nitrogenous glucosides, 109, 123. $126,136,185$

Nitrogenous organic manures, 22, 35

Nitrous acid, 51, 82

Non-albuminoid nitrogen, 109

Norlin, 134

North American maize, 119

Northerly aspect, 65

Northern counties, 208

Northumberland, 67, 78, 203, 209, 210

Norway, 206

Noyes, 222

Nux vomica, 156

Nystron, 134

OAK, 127, 162

Oats, 12, 106, 171, 205, 219

Occluded gas, 81

Offal, 22, 179

Oil, 22, 108, 135, 184, 191

Oils, drying, 108, 136, 138, 143

Oil seeds, 108, 117, 125, 135, 145

Oil substitutes, 136, 165

Oil theory of feeding, 195

Okey, 134

Old village sites, 21

Oleic acid, 108, 180

Olive oil, 137, 142, 144

Oliver, 100

Opium, 152

Orange, 167

Organic matter in soil, 76

Organic nitrogen, 17, 22, 109

Orr, 133

Orwin, 133

Osborne, 157

O'Sullivan, 134

Over-feeding of cows, 201

Ox feeding, 48, 178, 192, 197

Oxalic acid, 103

Oxidation, 50, 51, 156

Pacific Island phosphate, 30

Packing in soils, 62

Paddy, 120

Palace leas hay, 173

Palm kernels, 139

Palmitic acid, 108, 180

Palm nuts, 139, 189

Palm sago, 123

Pan, hard, 19, 63

Paper, 105, 128 
Paramecia, 81, 91

Parchment, 106, 161

Paring soils, 97

Parmentier, 147

Parry, 146

Partial sterilization, 90

Pasture, 29, 30, 81, 173, 204, 210

Peach, 167

Pear, 167

Peas, 150

Peat, 7, 45, 58, 97, 128

Peat moss litter, 45

Pectins, 105, 187

Pegler, 202

Penetration, 5, 7, 31, 34

Pentosans, 44, 105, 187

Pentoses, 105, 187

Peptones, 43, 50, 188

Perchlorate, potassium, 20

Peru, 35, 153

Pests, soil, 90

Petherbridge, 92

Petroleum spirit, 22, 33, 108, 136

Philippines, 111

Phlobaphenes, 163

Phosphate, 7, 22, 25, 74, 77, 94, 171,174

Phosphorus in animal, 49

Phosphorus in fertilizers, 25, 27

Phosphorus in soil, 26, 87, 94

Photosphere of sun, 65

Photo-synthesis, 101

Physical analysis of soil, 61,67

Physical condition of soil, 29, 86

Pickles, 103

Pig, 23, 48, 55, 183, 196, 197

Pig iron, 27

Pine needles, 58

Pine trees, 127, 145

Pith, sago, 123

Plant food, 10, 93, 169

Plimmer, 157, 190

Ploughing, 60, 66, 208, 218

Plum, 167

Polar regions, 2

Pondicherry, 142

Pool retting, 126

Poppy, 152

Porritt, 168

Postage stamp gum, 106

Potash, 7, 22, 37, 74, 97, 126, 171, 174

Potash, available, 36, 77, 87

Potash manure, 37, 162

Potassic super-phosphate, 40

Potassium ferro-cyanide, 38

Potassium in feeding, 48

Potassium hydrogen tartrate, 104

Potassium iodate, 19

Potassium nitratc, 21
Potassium perchlorate, 19

Potato, 12, 122, 151, 168, 171, 185, 205

Potato eyes, 185

Potato flour, 122, 207, 219

Potato stalks, 128, 185

Potato starch, 106, 122, 207

Potvliet, 133

Poudrette, 54

Poultry, 22, 56, 197

Poverty bottom, 98

Prairie soils, 3,86

Precipitated chalk spray, 168

Preservatives for timber, 127

Preservation of fruit, 167

Priestley, 90, 92

Primrose McConncll, 100, 223

Protein, 22, 109, 147, 185, 191

Prussian blue, 91

Prussic acid, 123, 136, 137, 143, 185

Pulp, 128, 161

Pulses, 40, 150

Punjab, 67, 118

Pupils, Agricultural, 210, 221

Purgative, 181

Purine, 181

Pyridine, 181

Pyrites, 71, 75, 165

Pyro-ligneous acid, 125, 130, 164

QueEnsLand, 111,112

Quicklime, 86

Quinidine, 154

Quinine, 154

RAB cultivation, 97

Radiation, 2, 65, 101, 198

Raffinose, 107, 108

Rag-bone, 33

Rank grass, 96

Rape, 24, 143

Raspberry, 167

Ratio $\mathrm{C}$ to $\mathrm{N}$ in soil, 77

Ratio of labour to land, 219

Ratio of lime to magnesia, 9, 73, 86

Ratio of manure to land, $3,40,169$, 220

Ratoon crops, 111, 174

Rawson, 168

Re-afforestation, 127, 162, 215

Reclamation, 92, 97, 100

Red beech, 72

Red hair, 72

Red soil, 66,162

Ren, 74, 96

Rendering oil, 108

Resin, 145

Retort charcoal, 129

Retting, 126 
Reversion of plant food, 31,51

Rhubarb, 103, 168

Rice, 95, 120, 121, 208

Ricin, 152

Richards, 58

Richmond, 202

Rideal, 58, 110

Ripening, 10, 17, 27, 175

Road sweepings, 67

Roberts, 134

Robertson, 36

Roller, use of, $62,69,80$

Root crops, 114, 116, 122, 151, 169

Roots, 5, 26, 40, 62

Ropes, 127, 143

Roscoe, 92, 224

Rosin, 145

Rotation of crops, 119, 212

Rotation of light, 108, 148

Rothamsted, 1, 17, 69, 76, 83, 195

Rotting, 50, 126

Rouelle, 147

Rowley, 134

Rubber, 108, 136, 163, 209

Rufisque, 142

Ruminants, 187, 193

Rural industries, 215

Rural schools, 221

Rushes, 128

Russell, 24, 58, 81, 84, 92 133, 224

Russian linseed, 135,136

Ruston, 168

Rye grass, 12

SACKING, 18, 126

Safflower, 143

Saffron, 143, 144

Sago, 123

Salad oil, 142

Sal ammoniac, 17

Salt, common, 37, 116, 172, 180

Sand, 39, 64, 71, 78, 94, 161

Saponification, 108, 140

Saponin, 24, 145

Sardines, 142

Sarson, 143

Sawdust, 45, 103, 127, 129

Scavenger, 54

Scents, 145

Schorlemmer, 92, 224

Schreiner, 85

Schryver, 134

Scientific training, 209

Scotland, soil, 93

Scott, 24

Scutching, 126

Sea-bird guano, 35

Sea Island cotton, 125

Sea water, $37,94,140$
Seaweed, 57, 132

Seeds, 38, 96, 108, 175

Seeds, hay, 173

Senegal, 142

Septic tank, 56

Sesame, 144

Sewage, 54

Sewage farm, 55

Shallow tillage, 69,94

Sheep, 48, 178, 196, 197, 204

Shell lime, 86

Shoddy, 23

Short, 190

Shortage of wheat, 20, 206

Shorthorn cows, 201

Shrinkage of soils, 70

Shrivell, 133

Shutt, 157

Sieve, 6, 25, 118

Silk waste, 23

Silt, 100

Silver, acetate, 152

Silvering mirrors, 104

Silver skin, 161

Simpson, 222

Singling turnips, 116

Sirocco, 159

Size of soil particles, $61,67,78$

Skatole, 181

Slag, 6, 8, 16, 20, 27, 63, 67, 97, 171, $174,179,203,208,218$

Slaughter house waste, 23

Slopes, terraced, 120, 158, 161

Sludge, 55

Smetham, 222

Smith, 134

Snyder, 224

Soap, 108, 140, 141, 142, 143, 144, 145

Soap nut, 24, 145

Sodium, 19, 74, 96

Sodium carbonate, 96

Sodium chloride, $37,116,172,180$

Sodium sulphate, 96

Soil, 7, 60, 161

Soil improvement, 86

Soil nitrogen, 81

Soil pests, 90

Soil water, 68

Solanin, 122, 185

Solar energy, 2, 65, 90, 101

Solubility of fertilizers, $4,10,27,34$, 41,169

Soluble albuminoids, 7, 22, 147

Soluble nitrogen, $10,34,41$

Soluble phosphate, $25,34,41$

Somerville, 98, 134, 179, 223

Soot, 17, 66, 92

Sorrel, 103 
Souchida, 145

Soudan sudd, 128

South African soya, 139

South America, 32, 139

Southerly aspect, 65

South Sea Island coconut, 139

Sowing seeds, $38,92,96$

Soy bean, 138, 151

Spain, 139

Specific gravity, 64, 199

Specific rotary power, 108,148

Sprayer, potato, 168

Spring wheat, 147

Squatter, Australian, 170

Standard sieve, 6, 25

Starch, 102, 106, 117, 119, 121, 122 , $123,124,137,180,191,207$

Starch equivalent, 195

Starch gelatinization, 106, 118, 207, 219

Steam sterilization of soil, 90

Stearic acid, 108, 180, 184

Stebbing, 134

Steel bomb calorimeter, 191

Stecl, by-products, 27

Sterilization, 22, 90, 156

Sterling, 168

Stevens, 168

Stiles, 110

Stimulating manures, $4,11,18,20$, $31,63,169$

Stinging nettles, 102

St. John, 202

Stock, live, 178

Stokes, 100

Stomach, 102, 188, 190, 193

Stones, 61, 78

Storage of manure, 50

Store beasts, 194

Storer, 224

Straw, 12, 45, 105, 126, 128, 136, 206

Strawberry, 167

Straw guni, 105

Straw pulp, 128, 193

Structure of soil, 61,171

Struggle for existence among plants, 8

Stachyose, 108

Strychnine, 156

Sub-soil, 19, 29, 60

Succulent crops, 17, 19, 175

Sucrose, 27, 107, 111, 167, 186

Sudd, Soudan, 128

Sugar, 27, 102, 111, 117, 167, 186

Sugar beet, 107, 108, 114

Sugar cane, 107, 111, 114, 174

Sugar refineries, 32,116

Sulphate of ammonia, 11, 40, 89, $110,110,159,162,171,175$
Sulphate of lime, $19,51,74,75,88$, $96,104,172,177$

Sulphide, calcium, 87

Sulphite, calcium, 91

Sulphite pulp, 128

Sulpho-cyanide, 88

Sulphur, 27, 75, 88, 89, 108, 165

Sulphur chloride, 108, 136

Sulphur dioxide, 16, 124, 128

Sulphur trioxide, 16

Sulphuric acid, 15, 75, 105, 136, 168

Sun, 1, 65, 101

Super-phosphate, 7, 12, 18, 19, 20, $22,30,35,97,171,177$

Supply and demand of plant food, 94

Supply of meat, 178, 207

Surface law of feeding, 194

Surface root, 35,176

Surface washing, soil, 7,19

Sussex pasture, 67

Sweated labour, 217

Swedes, 116, 151, 171, 176, 186 , 201

Sweet cassava, 123

Symons, 146

Synthetic nitrogen compounds, 11, 20,21

TANks, Irrigation, 95

Tannin, 162

Tan refuse, 45

Tapioca, 123

Tapping trees, 145,164

Tar, 125, 127, 128, 129

Tartar, 104

Tartaric acid, 104

Tea, 156, 158, 161, 175

Teaching, agricultural, 221

Tempany, 84

Temperate climates, 65

Terracing slopes, 120, 15S, 161

Tetra-calcium phosphate, 25

Tetra-saccharose, 108

Textiles, 123, 125

Theine, 156, 158, 160

Thomson, 157

Thorpe, 157, 223

Thread, 125

Tibbles, 224

Tillage, 62, 69, 94, 211

Til sced, 144

Timber, 125, 127, 129, 163, 215

Titanium, 72

Tobacco, 19, 21, 154

Tom, 134

Top dressing, 4, 15, 18, 19, 20, 22, 23, 31, 110, 119

Town stables, 50 
Tree Field, Cockle Park, 64, 81, 173,179

Trees, 123, 125, 127, 129, 139, 153, 163,215

Tri-calcium phosphate, 25, 31, 32

Tri-saccharose, 108

Tropical agriculture, 19, 54, 65, 95, $111,116,119,120,123,125,139$, 153,158

Tryptophane, 151, 181

Tull, Jethro, 1

Turnips, 19, 27, 30, 32, 69, 116, $136,183,201$

Turnip manure, 40, 116, 169

Turnor, 221

Turpentine, 109, 131, 145

\section{UNDERWOOD, 85}

United States, 111, 112, 119, 139, 170

Unit price, 41

Universities and agriculture, 220

Unsaturated oils, 108

Upper Tyne, 205

Uranium acetate, 109

Urea, 7, 42, 50, 191

Uric acid, 57, 181

Urine, 44, 47, 57, 192

Unripe fruits, 163

Usar, 74, 96

VAcuUM pan, 113

Vakil, 146

Vanadium, 27

Varnishes, 145

Vegetable cheese, 151

Vegetarian countries, 114

Ventilation of cow byres, 221

Vetch, 151

Vicilin, 150

Vinegar, 103, 125, 129, 147

Virgin soils, 3,60

Vitriolated bones, 34

Voelcker, 1, 24, 58, 59, 146, 223

Vorhees, 223

Vulcanization, 136, 165

WAGES, agricultural, 214, 220

Wallace, 133, 157

Wanklyn, 190

Warington, 84, 190, 202, 224

Warner, 110

Warping, 100

Waste animal matter, 23

Waste lime, 87
Waste wood, $125,129,163$

Water, 2, 49, 95, 183

Water in soil, $7,62,82,110$

Water, sewer, 55

Watt, 134

Wattle gum, 132

Wax, 108

Wax cloth, 144

Weathering of soil, 61

Weiss, 58

Well water, 21

Wentworth, 92

Western Ghats, cultivation, 97

West Indies, sugar, 111, 112

Wet lands, 95

Whatnough, 157

Wheat, 3, 12, 19, 20, 67, 105, 118, $147,150,171,191,195$

Wheat straw, 12, 105, 206

Whey, 107

Whitby, 168

White alkali, 74

White clover, wild, 82,172

White cotton seed, 125

White crops, 118, 171

White rice, 121

White sugar, 113

Wibberley, 223

Wild geranium, 174

Wild white clover, 82,172

Wiley, 133, 223

Willesden paper, 106

Williams, Gwilym, 157

Winter application of fertilizers, $16,21,23$

Winter wheat, 147

Wine, 104

Wireworms, 91, 92

Woburn, 19, 63

Wood (author), 133, 157, 182, 222

Wood (timber), 103, 125, 127, 128, $129,163,215$

Wood ash, 16, 37, 38

Wood tar, 128

Wool waste, 23

Worms, 5, 24, 145

Wright, 198, 223

Wurzel, mangel, 50, 114, 116

YELLOW plants, 15

Yule, 182

ZEIN, 148

Zinc chloride, 105, 106, 127, 128

Zinc oxide, 165

Zinc sulphate, 91 


\section{INDUSTRIAL}

CHEMISTRY

Being a Series of Volumes giving a Comprehensive Survey of

\section{THE CHEMICAL INDUSTRIES.}

Edited by SAMUEL RIDEAL, D.Sc. (Lond.), F.I.C., Fellow of University College, London.

NOW READY

Plant Products and Chemical Fertilisers

S. H. Collins, M.Sc., F.I.C. Pp. xvi +236 . Price $7 / 6$ net.

The Alkali Industry - . . J. R. Partington, D.Sc. (Vict.)

Pp. xvi +304 , with 63 figs. Price $7 / 6$ net.

Industrial Electrometallurgy E. K. RideAL, M.A.(Cantab.), Ph.D., F.I.C. Pp. xii +248 , with 26 figs. Price $7 / 6$ net.

The Application of the Coal Tar Dyestuffs

C. M. WhitTAKer, B.Sc.

IN THE PRESS

Pp. $x i i+214$. Price $7 / 6$ net.

Coal Tar Dyes and Intermediates

E. DE BARRY BARnetT, B.Sc., A.I.C.

Animal Proteids

H. G. Bennett, M.Sc. (Leeds).

The Carbohydrates.

S. RideAl, D.Sc. (Lond.), F.I.C., and Associates.

IN PREPARATION

The Industrial Gases

H. C. Greenwood, D.Sc. (Manchester).

Fats, Waxes, \& Essential 0ils

W. H. Simmons, B.Sc. (Lond.), F.I.C.

Silica and the Silicates

J. A. Audley, B.Sc. (Lond.), F.I.C.

The Rare Earths and Metals

E. K. Rideal, M.A. (Cantab.), Ph.D., F.I.C.

The Iron Industry

A. E. Pratt, B.Sc. (Lond.), Assoc. R.S.M.

The Steel Industry .

A. E. Pratt, B.Sc. (Lond.), Assoc. R.S.M.

Gas-Works Products .

H. H. Gray, B.Sc.

Organic Medicinal Chemicals

M. BarrowClifF, F.I.C., and F. H. CARR, F.I.C.

The Petroleum Industry .

Wood and Cellulose

Rubber, Resins, Paints and Varnishes
D. A. Sutherland, F.I.C.

R. W. Sindall, F.C.S., and W. Bacon, B.Sc., F.I.C., F.C.S.

R. S. Morrell, M.A., Ph.D.; A. E. WAELE, and the Editor. 

.

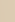







\section{PLEASE DO NOT REMOVE CARDS OR SLIPS FROM THIS POCKET}

\section{UNIVERSITY OF TORONTO LIBRARY}

S

Collins, S. Hoare (Sidney

585 Hoare)

C. 58

Plant products and chemical fertilizers

BioMed 

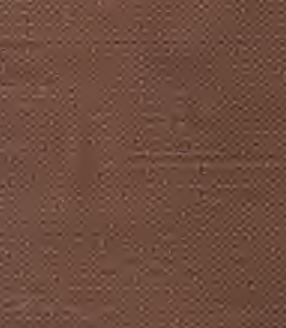

(x)

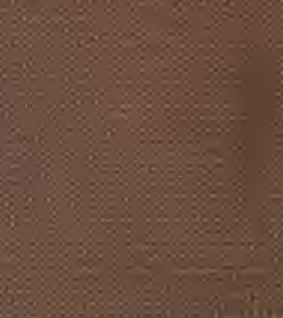

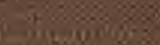

